SAUL HISSACI DE SOUZA

Estudo do encruamento, recristalização e evolução da textura cristalográfica da liga de alumínio AA 7108

São Paulo 
SAUL HISSACI DE SOUZA

\section{Estudo do encruamento, recristalização e evolução da textura cristalográfica da liga de alumínio AA 7108}

\section{Versão Corrigida}

Tese apresentada à Escola Politécnica da Universidade de São Paulo como parte dos requisitos para obtenção do título de Doutor em Ciências.

Área de Concentração:

Engenharia Metalúrgica e de Materiais

Orientador:

Prof. Dr. Angelo Fernando Padilha

São Paulo 
SAUL HISSACI DE SOUZA

Estudo do encruamento, recristalização e evolução da textura cristalográfica da liga de alumínio AA 7108

\section{Versão Corrigida}

Tese apresentada à Escola Politécnica da Universidade de São Paulo como parte dos requisitos para obtenção do título de Doutor em Ciências.

São Paulo 
Autorizo a reprodução e divulgação total ou parcial deste trabalho, por qualquer meio convencional ou eletrônico, para fins de estudo e pesquisa, desde que citada a fonte.

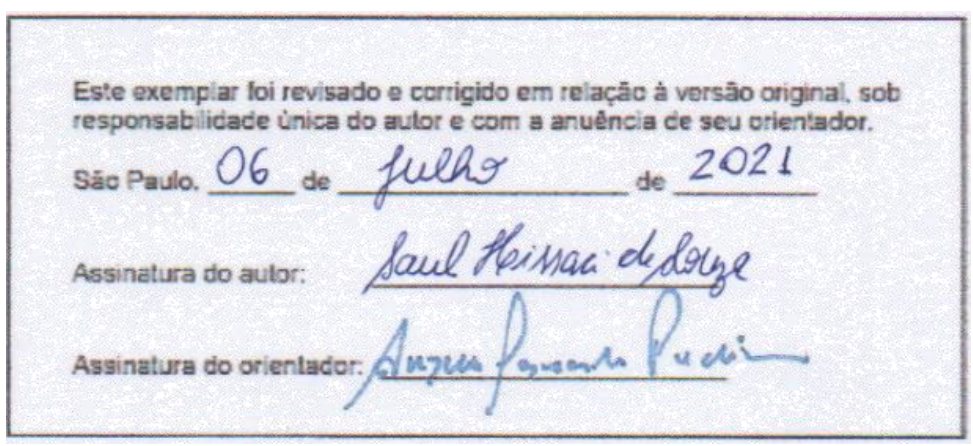

\section{Catalogação-na-publicaçăo}

\section{Saul Hissaci de Souza}

Estudo do encruamento, recristalização e evolução da textura cristalográfica da liga de alumínio AA 7108 / S. H. S. -- versāo corr. -- São Paulo, 2021. $188 \mathrm{p}$.

Tese (Doutorado) - Escola Politécnica da Universidade de São Paulo. Departamento de Engenharia Metalúrgica e de Materiais.

1.Ligas de alumínio 2.AA 7108 3.Textura cristalográfica 4.Envelhecimento natural. I.Universidade de São Paulo. Escola Politécnica. Departamento de Engenharia Metalúrgica e de Materiais II.t. 
Aos meus pais, Tadeu e lolanda, por dedicarem-se infindavelmente à minha criação. A minha esposa, Monica, por me encorajar a seguir atrás dos meus sonhos. À minha irmã, Priscila, sempre disposta a ajudar. Aos meus sogros, Lidia e Massami, por incentivarem a conclusão do presente trabalho e dessa etapa. 
"Miguilim, Miguilim, vou ensinar o que agorinha eu sei, demais: é que a gente pode ficar sempre alegre, alegre, mesmo com toda coisa ruim que acontece acontecendo. A gente deve de poder ficar então mais alegre, mais alegre, por dentro!"

\section{Campo Geral}

João Guimarães Rosa 


\section{AGRADECIMENTOS}

Ao professor Angelo Fernando Padilha, pelo suporte, pela paciência e por me ensinar que as mudanças que nos propomos a fazer em nossas trajetórias devem ser como as funções deriváveis: sem descontinuidades e sem pontos de inflexão!

A todos os colegas da pós-graduação, pelas conversas, conselhos e apoio durante a realização desse trabalho.

A todos os funcionários do PMT e PMI pelas contribuições mais do que fundamentais para a realização desse trabalho, em especial aos técnicos Rubens e Danilo (PMT), ao grande operador de MEV, Daniel (PMT) e ao técnico Jorge Sakamoto (PMI).

Ao professor Dr. Nelson Batista de Lima (IPEN) e ao Dr. Rene Ramos de Oliveira pelas colaborações, sugestões e ajuda com a determinação da macrotextura das amostras.

Aos funcionários da Companhia Brasileira de Alumínio (CBA), Miguel Borodiak e Alexandro Rafael de Andrade pela fundamental ajuda na preparação metalográfica das amostras utilizadas nesse trabalho.

À Coordenação de Aperfeiçoamento de Pessoal de Nível Superior (CAPES) pelo apoio financeiro durante a pesquisa desenvolvida (Código de Financiamento 001).

E a todos que contribuíram de alguma forma para a realização do presente trabalho. 


\section{RESUMO}

O presente trabalho apresenta um estudo acerca da evolução da textura cristalográfica durante o processamento da liga de alumínio AA 7108. As amostras foram recebidas na forma de barras extrudadas a quente e caracterizadas com as técnicas de microscopia óptica de luz polarizada, microscopia eletrônica de varredura, condutividade elétrica e ensaios de microdureza Vickers. A textura cristalográfica das amostras extrudadas foi estudada via difração de elétrons retroespalhados (microtextura) e difração de raios $-X$ (macrotextura). Observou-se que existia variação de textura cristalográfica ao longo da espessura da barra extrudada: enquanto uma textura de componente Cubo $\{001\}<100>$ foi encontrada na superfície de extrusão, uma componente adicional do tipo Goss $\{011\}<100>$ foi encontrada na região correspondente ao centro da barra. Após caracterização inicial, as amostras foram solubilizadas a $490^{\circ} \mathrm{C}$ por 5 horas e, em seguida, estudou-se a variação de dureza e de condutividade elétrica dessas amostras com o passar do tempo. Observou-se (por meio do aumento da dureza) a elevada capacidade de envelhecimento natural do material. Percebeu-se também que, ao contrário do poderia se esperar, as amostras solubilizadas possuíam condutividade maior do que as amostras naturalmente envelhecidas. A seguir, as amostras solubilizadas foram laminadas a frio utilizando-se duas reduções de espessura (33,7\% e 63,6 \%), sendo que cada redução foi obtida variando-se o número de passes. As amostras laminadas com maior número de passes mostraram tendência à formação de uma componente de textura Goss $\{011\}<100>$, enquanto as amostras laminadas com um menor número de passes apresentaram maior dispersão de componentes de textura, tendendo, além da componente Goss, formar a componente do tipo Latão \{001\} $<211$. Após recozimento a $490^{\circ} \mathrm{C}$, observou-se que as amostras deformadas com maior velocidade apresentaram microestrutura parcialmente recristalizada e textura com intensa componente (113) <332>, enquanto as amostras deformadas com menor velocidade apresentaram intensa recuperação e mantiveram a textura próxima à Goss $\{011\}<100>$ além de outras componentes ao longo da fibra $<110>$.

Palavras-Chave: Ligas de alumínio, AA 7108, Textura Cristalográfica, Envelhecimento Natural. 


\begin{abstract}
The present work presents a study about the evolution of crystallographic texture of aluminum alloy AA 7108 strips after thermomechanical process. The samples were received as hot extruded bars and characterized by optical microscopy of polarized light, scanning electron microscopy, electrical conductivity and Vickers hardness tests. The crystallographic texture as received samples was studied by electron backscatter diffraction (microtexture) and $X$ - ray diffraction (macrotexture). It was observed that there was change of crystallographic texture along the thickness of the extruded bar: While a Cube component texture $(<001><100>)$ was found on the extrusion surface, an additional Goss component $(\{011\}<100>)$ was found at half thickness of the bar. After initial characterization, the samples were solubilized at $490^{\circ} \mathrm{C}$ for 5 hours and then the hardness and electrical conductivity variation of these samples were studied over time. The high natural aging capacity of the material was observed (by the hardness increasing) and it was found that, unlike one could expect, the solubilized samples had higher conductivity than the natural aged samples. The solubilized samples were then cold rolled by using two thickness reductions (33.7\% and $63.6 \%)$, each reduction was obtained by varying the number of passes. The deformed strips were studied by using the same techniques described above. The rolled samples strained by using a larger number of passes showed a tendency to form a well-defined texture component (Goss $\{011\}<100>$ ), while the rolled samples strained by using a lower number of passes had a greater dispersion of texture components, tending, in addition to the Goss component, to form the Brass component $(\{001\}<211>)$. After an annealing at $490^{\circ} \mathrm{C}$, it was observed that the samples rolled with higher strain rate presented a partially recrystallized microstructure and texture with intense $(113)<332>$ component, whilst samples rolled with lower strain rate presented intense recovered microstructure and kept Goss $\{011\}<100>$ texture component.
\end{abstract}

Key words: Aluminum Alloys, AA 7108, Crystallographic Texture, Natural Aging. 


\section{LISTA DE ILUSTRAÇÕES}

Figura 1 - A primeira curva publicada por Alfred Wilm evidenciando o aumento da dureza de uma liga de Al com o passar do tempo [15]

Figura 2 - Influência do teor de Alumínio na dureza das ligas do sistema Al-Mg [19] 6 Figura 3 - A contribuição dos contornos de grão no aumento do limite de escoamento plotada em função da raiz quadrada do recíproco do diâmetro médio dos grãos para a liga $\mathrm{Al}-0,3 \% \mathrm{Cu}[27]$

Figura 4 -Fluxograma de classificação das ligas de alumínio conforme a Aluminum Association [33] ..... 10

Figura 5 - Diagrama de fases $\mathrm{Al}-\mathrm{Cu}$. Adaptado de [34] 11

Figura 6 - Mecanismo de Orowan para o movimento de discordâncias através de uma matriz metálica que contém precipitados [36] 12

Figura 7- llustração do mecanismo de cisalhamento de precipitado pela passagem de uma linha de discordância. 13

Figura 8 - Competição entre os mecanismos de cisalhamento de partícula e de Orowan. Uma distribuição de precipitados de $\mathrm{Al}_{3} \mathrm{Zr}$ com raio de aproximadamente $7 \mathrm{~nm}$ é a situação ótima, que resulta no maior ganho de resistência em relação ao material da matriz [37] 14

Figura 9 - Representação gráfica esquemática do tratamento térmico denominado Retrogression and Reaging. 16

Figura 10 - Secção isotérmica $\left(460^{\circ} \mathrm{C}\right)$ do sistema ternário Al-Zn-Mg [47] ............. 20

Figura 11 - Secção isotérmica $\left(400^{\circ} \mathrm{C}\right)$ do sistema ternário Al-Zn-Mg [47] .............. 20

Figura 12 - Secção isotérmica $\left(25^{\circ} \mathrm{C}\right)$ do sistema ternário Al-Zn-Mg [47]................ 21

Figura 13 - Diagrama genérico de energia livre de Gibbs por composição. Adaptado de [61] 24

Figura 14 - Diagrama de equilíbrio genérico indicando regiões de tendência à formação de intermetálicos estáveis e metaestáveis. Adaptado de [61]. 25 
Figura 15 - Curvas esquemáticas - isócrona (acima) e isotérmicas (abaixo) - de envelhecimento de uma liga de alumínio termicamente tratável. Na legenda, T1 $<$ T2 $<$ T3 $<$ T4. Adaptado de [55] 26

Figura 16 - Representação esquemática do processo de extrusão. Adaptado de [63] 27

Figura 17- Exemplos de produtos obtidos por extrusão do alumínio e suas ligas [64] 27

Figura 18 - Representação esquemática do processo de laminação de materiais metálicos. Adaptado de [63] 28

Figura 19 - Exemplos de produtos (bobinas e chapas) de alumínio e suas ligas obtidos por laminação [64] 28

Figura 20 - Principais parâmetros geométricos associados à laminação de planos. Adaptado de [65] 29

Figura 21 - Micrografias obtidas via microscopia eletrônica de transmissão de amostras de (a) cobre [69] e (b) alumínio [70], ambos de elevada pureza deformados plasticamente. 33

Figura 22 - Esquema ilustrando possíveis mecanismos de aniquilação de discordâncias - Adaptado de [72] 34

Figura 23 - Micrografias obtidas via microscopia eletrônica de transmissão de amostras de alumínio de alta pureza após deformação (à esquerda) e após recozimento a $250^{\circ} \mathrm{C}$ por 2 minutos (à direita) [73] 35

Figura 24 - Curva esquemática da cinética de recuperação de um material metálico deformado e recozido a temperatura constante. 36

Figura 25 - Mecanismo de migração de contornos pré-existentes. O contorno migra do grão $A$, menos deformado, na direção do grão $B$, mais deformado. As estruturas representadas dentro de cada grão são células de discordâncias 38

Figura 26 - Formação de um núcleo de recristalização a partir de um subgrão. (A) arranjo inicial, (B) O subgrão maior cresce às custas dos vizinhos, (C) Núcleo de recristalização é formado. [73] 38 
Figura 27 - Coalescimento de subgrãos. (a) Arranjo inicial antes da ocorrência do fenômeno, (b) Migração de subcontornos que causa efeito similar à rotação do subgrão CDEFGH. (c) Subgrão coalescido [80] 39

Figura 28 - Curvas baseadas no modelo JMAK para alumínio de elevada pureza deformado $40 \%$ por laminação e recozido em diferentes temperaturas [83]..... 41

Figura 29- Efeito de teores de Fe em solução sólida na cinética de recristalização do Al de alta pureza (1XXX) [87] 42

Figura 30 - Estrutura esquemática representando a distorção na rede gerada ao redor de partículas intermetálicas grosseiras [88]

Figura 31 - Micrografia obtida com auxílio de microscopia eletrônica de varredura (modo elétrons retroespalhados) evidenciando a recristalização ao redor de partícula de fase intermetálica para a liga AA 3003 deformada a frio. [89]

Figura 32 - - Curvas TTT esquemáticas para recristalização e precipitação em ligas de alumínio. Adaptado de [91] 44

Figura 33- Micrografia obtida por microscopia eletrônica de varredura (no modo elétrons retroespalhados) da $\mathrm{Al}-0,12 \% \mathrm{p}$ Sc deformada e recozida por um minuto a $425^{\circ} \mathrm{C}[92]$ 44

Figura 34 - a) Ocorrência de recuperação estática em materiais de alta EDE submetidos à laminação a quente (baixo grau de deformação). b) Em materiais de baixa EDE é possível que haja, além da recuperação dinâmica, recristalização após deformação a quente. C) elevados graus de deformação (como a extrusão) e altas temperaturas de deformação aplicados em materiais de alta EDE tendem a promover a recuperação dinâmica e a recristalização após deformação (estática). d) Já aplicando as mesmas condições do item anterior à materiais de baixa EDE, tende-se à obter uma estrutura de grãos recristalizados de maneira dinâmica - Adaptado de [95]

Figura 35 - Representação esquemática do fenômeno de crescimento de grão [73]

Figura 36 - Macrografia de tubo extrudado da AA 6005. Nota-se a presença da zona de grãos grosseiros nas regiões periféricas [99] 
Figura 37 - Representação esquemática do mecanismo de formação do PCG proposto por Eivani. (a) A microestrutura inicial possui grãos aproximadamente equiaxiais. (b) A ocorrência da deformação plástica leva à formação de subgrãos. (c) Os subgrãos formados diminuem de tamanho com a continuidade da deformação. Ao mesmo tempo ocorre a formação de uma estrutura parcialmente recristalizada (de maneira dinâmica). (d) Ao fim do processo de deformação, ocorre a nucleação e o crescimento de novos grãos de maneira estática. (e-f) Os grãos recristalizados de maneira estática crescem mais rapidamente do que os que foram recristalizados de maneira dinâmica, dando origem a microestrutura de grãos grosseiros periféricos . 50 Figura 38 - Representação esquemática de chapa metálica com textura tipo cubo. DL, DN e DT representam as direções de laminação, normal e tranversal, respectivamente 55

Figura 39 - Representação dos sistemas de coordenadas da amostra $(A)$ e do cristal (C). Os ângulos $\alpha_{1}, \beta_{1}$ e $\gamma_{1}$ são respectivamente os ângulos entre a direção de laminação (DL) e as direções dos eixos do cristal ............................................. 56

Figura 40 - Representação da textura do tipo Cubo Rodado $(\{001\}<110>$ ) em uma chapa metálica laminada [109] ...................................................................... 58

Figura 41 - Representação das rotações $\phi_{1}, \phi_{2} \mathrm{e} \Phi$ realizadas de modo a fazer o eixo da amostra coincidir com o eixo do cristal. Adaptado de [110] .............................. 59

Figura 42 - Exemplo de representação de orientação no Espaço de Euler ............. 60 Figura 43 - Projeção de um dado plano cristalino na esfera de referência para formação das figuras de polo ....................................................................... 61

Figura 44 - Representação da projeção estereográfica dos planos cristalinos da família (100), (110) e (111). Em vermelho, está destacado o chamado triângulo

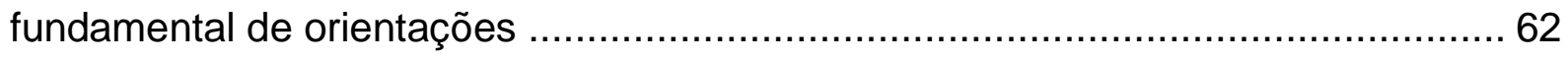

Figura 45 - Projeção da orientação de 5 grãos sobre o triângulo fundamental de orientações 62

Figura 46 - Representação da orientação cristalina por meio de curvas de isonível plotadas no triângulo fundamental de orientações [111] 63 
Figura 47 - Figuras de pólo relativas às familias de planos a) (100), b) (110) e c) (111) de um material com forte textura do tipo Cubo. Adaptado de [111]

Figura 48 - A rotação de um cristal altera suas direções cristalográficas em relação à amostra macroscópica, enquanto o plano paralelo cristalográfico pode ser manter paralelo à superfície 64

Figura 49 - Representação das componentes Latão e Goss no Espaço de Euller. Para facilitar a visualização, são plotadas seções de $\varphi 2$ constante em intervalos de $5^{\circ}$ [113] 65

Figura 50 - Ábaco auxiliar para interpretação das FDO’s. [112] 66

Figura 51 - Localização espacial das principais fibras do sistema CFC no Espaço de Euller. [108] 67

Figura 52 - Variação de $\mathrm{f}(\mathrm{g}) \operatorname{com}$ 甲2 para o cobre de elevada pureza e para duas ligas cobre zinco com diferentes teores de zinco. Nota-se que a adição de elementos de liga altera a textura de deformação das ligas em relação aos metais puros [114] (EXEMPLO COM AL) . 68

Figura 53 - Representação dos cortes realizados nas amostras das barras extrudadas de AA 7108. A macrotextura foi estudada nas três superfícies indicadas. 73 Figura 54 - Fluxograma resumo dos procedimentos experimentais realizados a partir das amostras de AA 7108 extrudadas. 76 Figura 55 - Macrografias das seções transversais dos lingotes da liga AA 7108 nas condições (a) bruta de solidificação e (b) homogeneizada. Obtidas por meio de ataque com reagente de Tucker. 78

Figura 56 - Micrografias ópticas obtidas com auxílio de luz polarizada das amostras brutas de solidificação. As setas relacionam a micografia com o local em que foram extraídas as amostras 80

Figura 57 - Micrografias ópticas obtidas com auxílio de luz polarizada das amostras homogeneizadas. As setas relacionam a micografia com o local em que foram extraídas as amostras 81

Figura 58 - Ciclo térmico adotado na CBA para realização do tratamento térmico de homogeneização [11] 82 
Figura 59 - Micrografia obtida por microscopia eletrônica de varredura (modo elétrons secundários) da amostra bruta de solidificação

Figura 60 - Micrografia obtida por microscopia eletrônica de varredura (modo elétrons secundários) da amostra homogeneizada

Figura 61 - Micrografia obtida por microscopia eletrônica de varredura (modo elétrons retroespalhados) da amostra bruta de solidificação. É possível notar a presença de fases intedendríticas assim como o fenômeno de microssegregação 85

Figura 62 - Micrografia obtida por microscopia eletrônica de varredura (modo elétrons retroespalhados) da amostra bruta de solidificação. As setas indicam regiões e pontos analisados via EDS e as respectivas composições químicas associadas 86

Figura 63 - Micrografia obtida por microscopia eletrônica de varredura (modo elétrons retroespalhados) da amostra bruta de solidificação. As setas indicam regiões e pontos analisados via EDS e as respectivas composições químicas associadas

Figura 64 - Micrografia obtida por microscopia eletrônica de varredura (modo elétrons retroespalhados) da amostra homogeneizada. Observa-se uma atenuação do fenômeno de microssegregação. Nota-se também a diminuição da concentração de intermetálicos, indicando que houve solubilização de algumas dessas fases 88 Figura 65- Micrografia obtida por microscopia eletrônica de varredura (modo elétrons retroespalhados) da amostra homogeneizada. As setas indicam regiões e pontos analisados via EDS e as respectivas composições químicas associadas 89 Figura 66 - Difratograma da AA 7108 nos estados bruto de solidificação e homogeneizado. São indicadas as famílias de planos relativas ao alumínio em cada um dos dois estados avaliados 90

Figura 67 - Difratograma da AA 7108 nos estados bruto de solidificação e homogeneizado. São indicadas as famílias de planos relativas à fase $\mathrm{Mg}_{0,97} \mathrm{Zn}_{0,03 .} 91$ Figura 68 - Difratograma da AA 7108 nos estados bruto de solidificação e homogeneizado. O "asterisco" indica um pico que não pode ser inequivocadamente identificado, já que esse está compreendido em um intervalo de ângulos em que tanto picos de $\mathrm{Al}_{3} \mathrm{Ti}$ quanto de $\mathrm{Fe}_{4} \mathrm{Zn}_{9}$ fazem-se presentes 92 
Figura 69 - Gráficos de "a" x " $\cos ^{2} \theta / \operatorname{sen} \theta$ " para as amostras nos estados bruto de solidificação e homogeneizado. A reta indicada em cada um dos gráficos foi obtida por meio do método dos mínimos quadrados e representa a melhor equação que representa o conjunto de dados experimentais indicados pelos pontos .94

Figura 70 - Micrografias ópticas obtidas com auxílio de luz polarizada da amostra extrudada. DT representa a direção transversal, DL representa a direção de laminação e DN representa a direção normal em relação ao processo de extrusão. A micrografia à direita representa a superfície de extrusão SE .95

Figura 71 - Micrografias ópticas obtidas com auxílio de luz polarizada para a seção tranversal da amostra extrudada. As imagens indicam a diferença entre o tamanho médio dos grãos do centro e os da periferia. 96

Figura 72 - Micrografia obtida por microscopia eletrônica de varredura da amostra extrudada. Os intermetálicos encontrados (junto com as análises via EDS) são mostrados na imagem 97

Figura 73 - Micrografia obtida por microscopia eletrônica de varredura da amostra extrudada. Os intermetálicos encontrados (junto com as análises via EDS) são mostrados na imagem 98

Figura 74 - Difratograma da AA 7108 extrudada. São indicadas as famílias de planos relativas à cada um dos picos identificados. Abaixo da curva, são apontadas as posições dos picos encontradas nas fichas padrão mencionadas 99

Figura 75 - Mapeamento de dureza Vickers realizado sobre a seção transversal da barra extrudada da AA 7108 99

Figura 76 - Mapeamento de orientações (EBSD) da superfície de extrusão na (a) periferia e (b) centro da AA 7108 100

Figura 77 - Mapeamento de orientações (EBSD) da superfície de extrusão na (a) periferia e (b) centro da AA 7108. Os contornos representados na coloração azul representam contornos de médio ângulo, enquanto os contornos representados na coloração preta representam contornos de alto ângulo 101

Figura 78 - FDO obtida via EBSD X relativa à AA 7108 extrudada. A análise foi realizada na superfície de extrusão em região próxima à periferia 102 
Figura 79 - FDO obtida via EBSD X relativa à AA 7108 extrudada. A análise foi realizada na superfície de extrusão em região próxima ao centro 102

Figura 80 - Figuras de pólo obtidas por análise via difração de raios $X$ relativas à superfície de extrusão (S.E.), 1/4 abaixo da superfície e para o centro da amostra (1/2) 103

Figura 81 - FDO obtida via difratometria de raios $X$ relativa à AA 7108 extrudada. $A$ análise foi realizada na superfície de extrusão 104

Figura 82 - FDO relativa à AA 7108 extrudada. A análise foi realizada na metade da barra, em superfície paralela à superfície de extrusão 105

Figura 83 - FDO relativa à AA 7108 extrudada. A análise foi realizada a $1 / 4$ de espessura abaixo da superfície de extrusão. 106

Figura 84 - Gráfico de fibra ao longo da família de direções $<100\rangle\left(\varphi 1=0, \varphi_{2}=0\right.$ e 0 $<\phi<4^{\circ}$ ) relativo às amostras extrudadas ao longo da espessura. 107

Figura 85 - Estimativa da profundidade de penetração da radiação Cu-K $\alpha$ em função de $G_{x}$ para cada família de planos do sistema CFC que promovem a difração da radiação 109

Figura 86 - Difratogramas da AA 7108 relativos à superfície de extrusão a) da amostra preparada (lixada e polida) e b) da amostra sem preparação. A diferença de intensidade relativa entre os picos dos difratogramas indica a possibilidade de diferentes componentes de textura estarem presentes para cada caso 110

Figura 87 - Gráficos a $x \cos ^{2} \theta / \operatorname{sen} \theta$ para a superfície de extrusão (obtida pela remoção da camada de grãos grosseiros) e para a PCGZ. O termo independente indicado nas equações indicadas em cada gráfico corresponde à estimativa para o valor do parâmetro de rede da matriz rica em Al

Figura 88 - Mapeamento de orientações (EBSD) da seção transversal. Imagem obtida próxima à fronteira amostra/baquelite. 112 Figura 89 - Figuras de polo associadas à PCGZ. 113 
Figura 90 - FDO relativa à AA 7108 extrudada. A análise foi realizada sem preparação metalográfica prévia, de modo a avaliar a textura dos grãos periféricos e grosseiros

Figura 91- Modelo proposto para descrever a formação da PCGZ nos materiais extrudados. Inicialmente, tem-se o material a temperatura ambiente (A) que é aquecido a temperaturas superiores à de solubilização (B) e submetido à extrusão (C). A periferia é submetida a maiores taxas de deformação e ocorre nessa região a formação de subgrãos menores e mais numerosos, o que por sua vez promove a recristalização durante o processamento mecânico a quente (C e D). A recristalização na periferia é concluída enquanto novos grãos ainda estão sendo formados no centro (E). Os grãos recristalizados na região periférica crescem enquanto a recristalização é concluída na região central $(\mathrm{F})$. O material, após resfriamento, apresenta a microestrutura exibida esquematicamente em (G) .......................................... 116

Figura 92 - Microestruturas esquemáticas associadas à precipitação de uma liga de alumínio endurecível por precipitação ( $\mathrm{T} 1<\mathrm{T} 2<\mathrm{T} 3<\mathrm{T} 4)$ 118

Figura 93 - Evolução da dureza a temperatura ambiente da amostra solubilizada a $490^{\circ} \mathrm{C}$ por 5 horas 119

Figura 94 - Evolução da condutividade elétrica a temperatura ambiente da amostra solubilizada a $490^{\circ} \mathrm{C}$ por 5 horas 119

Figura 95 - Variação da dureza em função da condutividade elétrica. A linha vermelha mostra a função de segundo grau que melhor se ajusta ao conjunto de dados.... 120 Figura 96 - Representação gráfica da deformação real acumulada em função do número de passes realizados. As amostras selecionadas para análise estão indicadas em cada um dos gráficos. 123

Figura 97 - Micrografias ópticas obtidas com auxílio de luz polarizada para as amostras deformadas por laminação. Acima de cada imagem é indicada o sentido de laminação e a especificação (simbologia adotada nesse trabalho) da amostra em relação ao grau de redução e ao número de passes 124

Figura 98 - Variação da dureza com o tempo das amostras laminadas e mantidas em congelador comercial 126 
Figura 99 - Variação da dureza com o tempo das amostras laminadas e mantidas em temperatura ambiente. A amostra somente solubilizada também foi estudada a título de comparação

Figura 100 - Gráfico da fração transformada em função do tempo para as amostras solubilizadas, A60 e B60 128

Figura 101 - Ajuste dos dados experimentais de dureza Vickers das amostras A60, B60 e somente solubilizada ao modelo JMAK 129

Figura 102 - Ajuste dos dados experimentais de dureza Vickers das amostras A60, B60 e somente solubilizada ao modelo Austin-Rickett 130

Figura 103 - Figuras de polo associadas às amostras laminadas. A indicação à esquerda mostra de qual tira referem-se as figuras de polo. 131

Figura 104 - FDO relativa à superfície de laminação da amostra A 30 132

Figura 105 - FDO relativa à superfície de laminação da amostra B 30 133

Figura 106 - FDO relativa à superfície de laminação da amostra A 60 134

Figura 107 - FDO relativa à superfície de laminação da amostra B 60 135

Figura 108 - Gráfico de fibra ao longo da família de direções $<100>(\varphi 1=0, \varphi 2=0$ e $0<\phi<45^{\circ}$ ) relativo às amostras solubilizadas e laminadas a frio 136

Figura 109 - Gráfico de fibra $\alpha\left(0<\varphi 1<35^{\circ}, \phi=45^{\circ}\right.$ e $\left.\varphi 2=0\right)$ relativo às amostras solubilizadas e laminadas a frio 136

Figura 110 - Micrografia óptica obtida com auxílio de luz polarizada para a amostra deformada por laminação (A30) seguida de recozimento a $490^{\circ} \mathrm{C}$ por 1 hora 137

Figura 111 - Micrografia óptica obtida com auxílio de luz polarizada para a amostra deformada por laminação (B30) seguida de recozimento a $490^{\circ} \mathrm{C}$ por 1 hora 138

Figura 112 - Micrografia óptica obtidas com auxílio de luz polarizada para a amostra deformadas por laminação (A60) seguida de recozimento a $490^{\circ} \mathrm{C}$ por 1 hora. As flechas indicam pequenos grãos recristalizados em meio ao material encruado ... 139 Figura 113 - Micrografia óptica obtida com auxílio de luz polarizada para a amostra deformada por laminação (B60) seguida de recozimento a $490^{\circ} \mathrm{C}$ por 1 hora 139 
Figura 114 - Micrografia óptica obtida com auxílio de luz polarizada para a amostra deformada por laminação (A60) seguida de recozimento a $490^{\circ} \mathrm{C}$ por 14 horas ... 140 Figura 115 - Micrografia óptica obtida com auxílio de luz polarizada para a amostras deformada por laminação (B60) seguida de recozimento a $490^{\circ} \mathrm{C}$ por 14 horas ... 141 Figura 116 - Variação da dureza com o tempo das amostras A60 e B60 recozidas e deixadas em temperatura ambiente (aproximadamente a $25^{\circ} \mathrm{C}$ ) 142

Figura 117 - FDO relativa à superfície de laminação da amostra A 60 após tratamento térmico a $490^{\circ} \mathrm{C}$ por 14 horas. 143

Figura 118 - FDO relativa à superfície de laminação da amostra B 60 após tratamento térmico a $490^{\circ} \mathrm{C}$ por 14 horas. 144

Figura 119 - Gráfico de fibra ao longo da família de direções $\left\langle 100>\left(\varphi 1=0, \varphi_{2}=0\right.\right.$ e 0 $<\phi<45^{\circ}$ ) relativo às amostras $\mathrm{A} 60$ e $\mathrm{B} 60$ recozidas por 14 horas a $490^{\circ} \mathrm{C}$ 145

Figura 120 - Gráfico de fibra (ao longo da faixa de ângulos $0<\varphi 1<90^{\circ}, \varphi 2=45^{\circ}$ e $\phi$ $=25^{\circ}$ ) relativo às amostras $\mathrm{A} 60$ e $\mathrm{B} 60$ recozidas por 14 horas a $490^{\circ} \mathrm{C}$ 145

Figura 121 - Mapeamento de orientações (EBSD) da amostra A60 recozida a $490^{\circ} \mathrm{C}$ 


\section{LISTA DE TABELAS}

Tabela 1 - Solubilidade máxima de alguns elementos de liga no alumínio. Adaptado

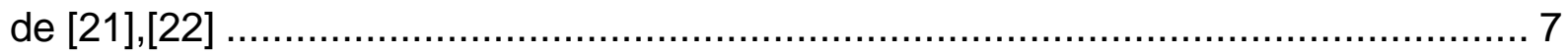

Tabela 2 - Algumas propriedades da liga AA 7108 [40] ................................. 17

Tabela 3 - Limites de composição para a liga AA 7108 [33] .................................. 17

Tabela 4 - Coeficientes de difusão de alguns elementos em alumínio a $470^{\circ} \mathrm{C}$.

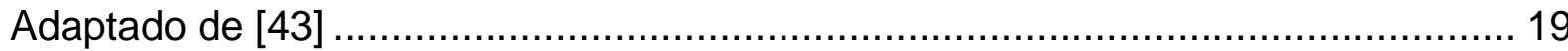

Tabela 5 - Valores de n (expoente de crescimento de grão) para diferentes metais de alta pureza [73]

Tabela 6 - Compilado de resultados de estudos relacionados à extrusão do alumínio e suas ligas 52

Tabela 7 - Índices de Miler e ângulos de Euler das principais componentes de textura encontradas em metais e ligas de estrutura CFC [108], [117] 69

Tabela 8 - Composição da AA 7108 utilizada no presente trabalho 70

Tabela 9 - Densidade e coeficiente de absorção mássica dos elementos que constituem a AA 7108 para a radiação CuKa [122] .......................................... 108

Tabela 10 - Dureza e condutividade da AA 7108 no estado como recebido 117

Tabela 11 - Dureza e condutividade da AA 7108 após tratamento de solubilização $\left(490^{\circ} \mathrm{C}\right.$ por 5 horas) seguido de envelhecimento artificial $\left(120^{\circ} \mathrm{C} / 24\right.$ horas $\left.-\mathrm{T} 6\right) ; 120$ Tabela 12 - Reduções de espessura das amostras em relação ao número de passes de laminação 122

Tabela 13 - Medidas de dureza e condutividade elétrica medidas imediatamente após laminação a frio das amostras 125

Tabela 14 - Comparativo entre os valores de $\mathrm{R}^{2}$ associados ao ajuste dos dados experimentais aos modelos JMAK e Austin-Rickett 130

Tabela 15 - Parâmetros de ajuste entre modelos polinomiais do segundo grau e os dados empíricos relativos ao envelhecimento natural das amostras deformadas.. 142 



\section{SUMÁRIO}

1. INTRODUÇÃO E OBJETIVOS DO TRABALHO

2 REVISÃO BIBLIOGRÁFICA 3

2.1 Endurecimento por precipitação - um breve histórico ....................................... 3

2.2 Mecanismos de endurecimento - uma síntese............................................... 4

2.2.1 Endurecimento por solução sólida ……………................................... 5

2.2.2 Endurecimento por refino de grão......................................................... 7

2.2.3 Endurecimento por deformação plástica ……………………………....... 9

2.2.4 Sobre o endurecimento por precipitação nas ligas de alumínio ....................... 10

2.2.5 Mecanismo de endurecimento por precipitação coerente ................................ 11

2.2.6 Partículas contornadas pela pelas linhas de discordância - O mecanismo de

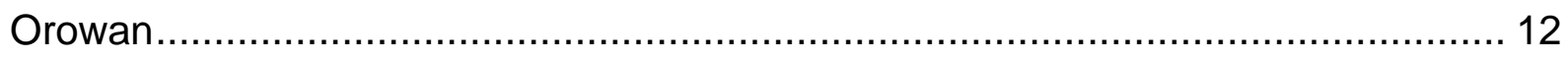

2.2.7 Partículas cisalhadas pelas linhas de discordância. .................................... 13

2.2.8 Competição entre os mecanismos de Orowan e de cisalhamento de partículas 14

2.3 Tratamentos térmicos aplicados em ligas de alumínio .................................... 15

2.4 A liga AA 7108

2.5 Condutividade elétrica do alumínio e suas ligas .......................................... 21

2.5.1 O caso "clássico" - aumento da condutividade com a formação de precipitados

2.5.2 O caso anômalo - o aumento da condutividade após tratamento de

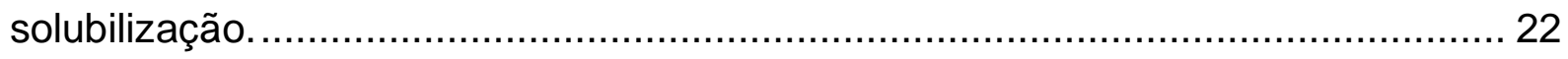

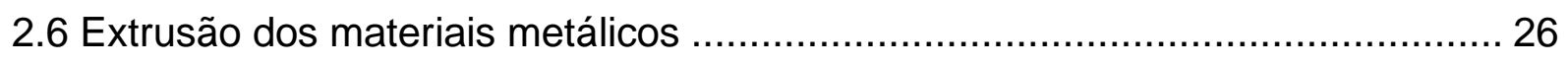

2.7 Laminação dos materiais metálicos ............................................................ 27

2.7.1 Relações geométricas na laminação de planos ........................................... 29 
2.7.2 O fator delta

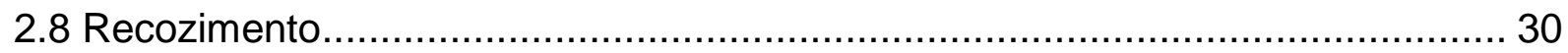

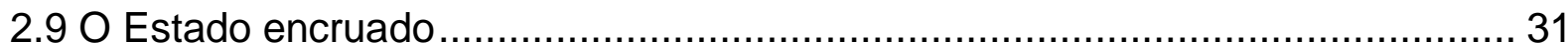

2.9.1 Fatores que afetam a distribuição e a densidade de defeitos após deformação

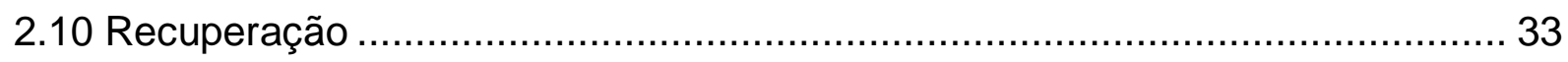

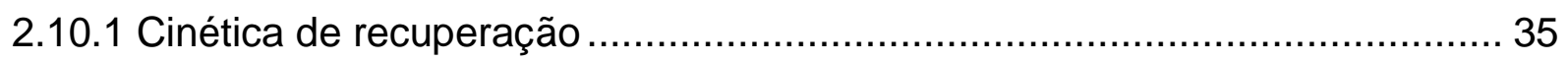

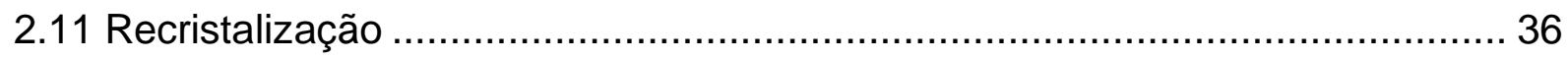

2.11.1 Nucleação da recristalização ............................................................... 37

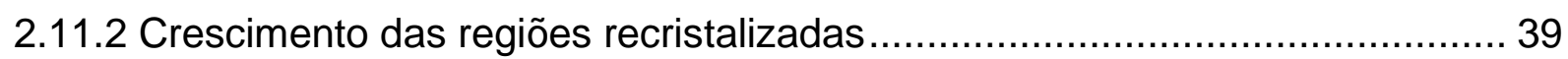

2.11.3 Cinética de recristalização ................................................................... 40

2.11.4 Influência da presença de partículas de segunda fase e de átomos de soluto

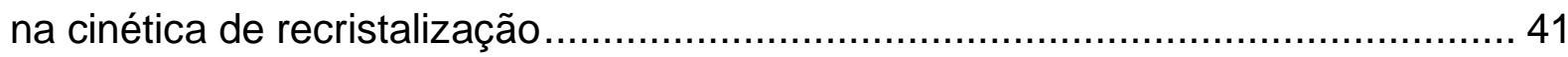

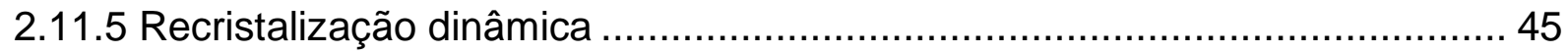

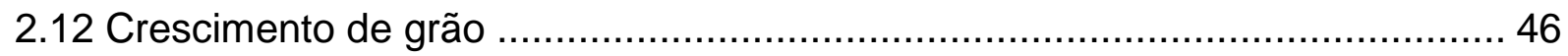

2.12.1 Cinética de crescimento de grão........................................................... 47

2.13 PCGZ - Zona de grãos periféricos grosseiros .............................................. 48

2.14 Textura cristalográfica nos materiais metálicos.......................................... 55

2.14.1 Descrição das orientações e representação das texturas cristalográficas .... 56

2.14.2 Sistemas de coordenadas - amostra e cristal.......................................... 56

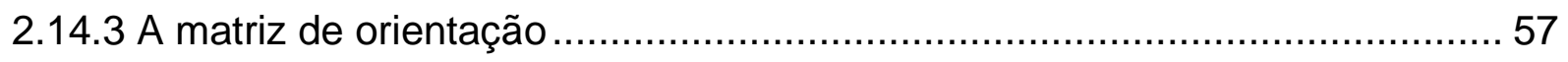

2.14.4 A Orientação ideal (índices de Miller - Bravais) .......................................... 58

2.14.5 Os ângulos de Euler e o espaço de Euler …………................................ 59

2.14.6 Representação gráfica - projeção estereográfica e figuras de polo ...............60

2.14.7 Função Distribuição de Orientação (FDO) ................................................ 63

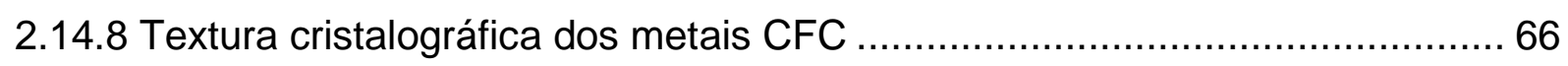




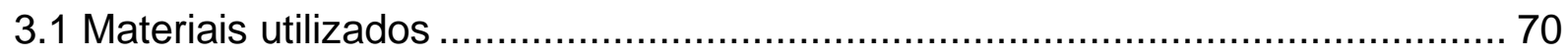

3.2 Caracterização do material como recebido .................................................. 70

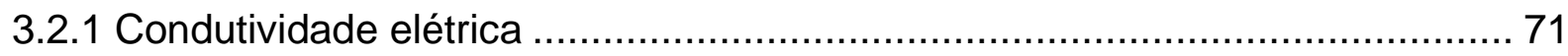

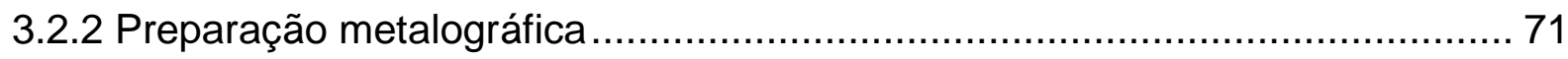

3.2.3 Microscopia óptica de luz polarizada (M.O) …….................................... 71

3.2.4 Microscopia eletrônica de varredura (MEV) ………................................... 72

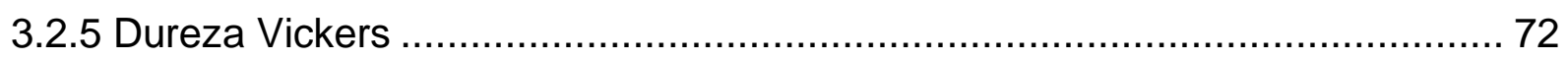

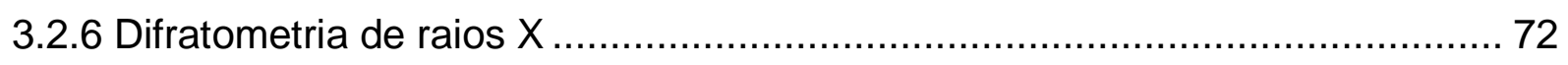

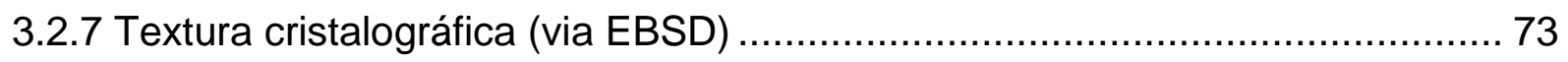

3.2.8 Textura cristalográfica (via difratometria de raios $\mathrm{X}$ ) ….............................. 73

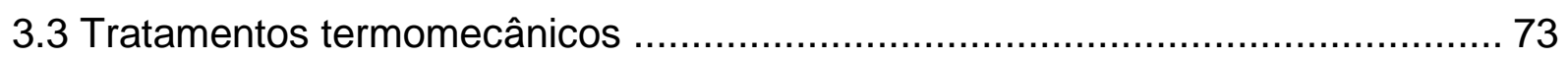

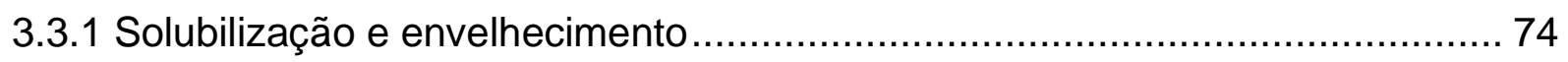

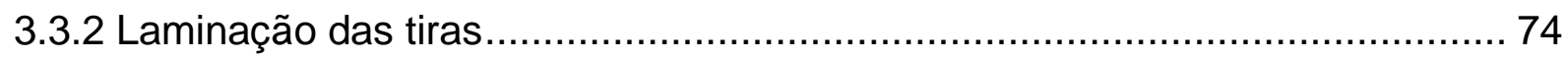

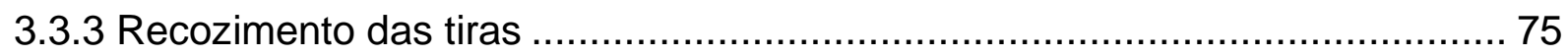

4. RESULTADOS E DISCUSSÃO

4.1 Caracterização microestrutural das amostras fundidas e homogeneizadas ....... 77

4.2 Caracterização microestrutural, medição de dureza Vickers e obtenção da macro e microtextura cristalográfica das amostras extrudadas ..................................... 94

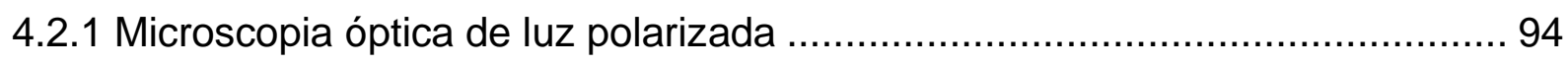

4.2.2 Microscopia eletrônica de varredura, EDS e DRX ……………………....... 96

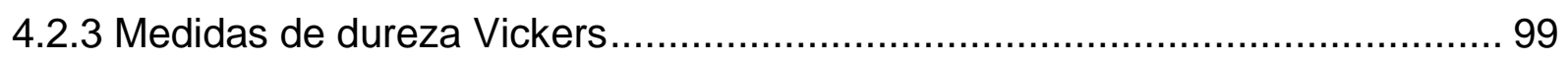

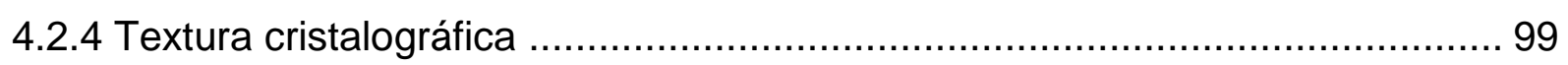

4.2.5 Textura cristalográfica da zona de grãos grosseiros periféricos (PCGZ)....... 107 
4.3 Caracterização microestrutural, medição de dureza Vickers e obtenção da macro e microtextura cristalográfica das amostras após processamento termomecânico.

4.3.1 Solubilização e envelhecimento das amostras.......................................... 117

4.3.2 Laminação das amostras solubilizadas................................................... 120

4.3.3 Análise da textura cristalográfica das tiras laminadas ............................... 130

4.4 Caracterização microestrutural, medição de dureza Vickers e obtenção da macro e microtextura cristalográfica das amostras recozidas ..................................... 137

5. CONCLUSÕES 147

6. SUGESTÕES PARA TRABALHOS FUTUROS 149

7. REFERÊNCIAS BIBLIOGRÁFICAS 150 


\section{INTRODUÇÃO E OBJETIVOS DO TRABALHO}

As ligas de alumínio da série 7XXX (endurecíveis por precipitação coerente) são amplamente utilizadas nas áreas de aeroespacial e de transporte em virtude de sua elevada resistência mecânica e leveza [1]. A liga AA 7108 é uma liga do sistema Al$\mathrm{Mg}-\mathrm{Zn}$ (podendo também possuir pequenos teores de $\mathrm{Ti}$ e $\mathrm{Zr}$ ) que encontra sua principal aplicação na construção de veículos para transporte terrestre. Embora a AA 7108 não possua o mesmo nível de resistência mecânica de outras ligas, como a AA 7075, ela não apresenta os recorrentes problemas de tenacidade e de susceptibilidade à corrosão sob tensão, algo comum em ligas de alumínio de alta resistência aplicadas na indústria aeronáutica [2].

O principal objetivo do presente trabalho é estudar a evolução da textura cristalográfica da liga AA 7108 ao longo de determinadas etapas de processamento termomecânico - partindo da fusão e vazamento do material, passando por processos de extrusão a quente e laminação, até chegar ao recozimento em diferentes condições de tempo e temperatura.

No que se refere às técnicas experimentais utilizadas, além da análise via microscopia óptica e microscopia eletrônica de varredura, foram tomadas medidas de dureza Vickers e realizados ensaios de difratometria de raios-X. Para a caracterização da textura cristalográfica foram utilizadas as técnicas de EBSD (análise da microtextura) e difratometria de raios $X$ (análise da macrotextura), sendo que a avaliação da textura foi realizada ao longo da espessura da barra.

Do ponto de vista científico-acadêmico, tal estudo é justificado principalmente pela escassez de estudos a respeito da AA 7108. Consultas realizadas na base de dados Scopus mostram uma diferença significativa entre o número de resultados para as buscas 'AA 7075' e 'AA 7108' - Enquanto para a primeira são encontrados mais de 300 resultados, para a segunda são encontrados apenas três (consulta realizada no dia 16/01/2019, sem utilização de outros filtros). Uma exaustiva revisão inicial realizada em outras bases indexadas (durante o início da realização do presente trabalho) encontrou oito trabalhos envolvendo a liga AA 7108, sendo três relacionados às propriedades mecânicas do material submetido a ensaios de tração -[3],[4] e [5], três relacionados ao processo de extrusão a quente - [6],[7] e [8] e dois relacionados 
a processos de soldagem por feixe de elétrons - [9] e [10]. Os trabalhos mencionados não abordavam diretamente temas como textura cristalográfica e formação da zona de grãos periféricos grosseiros na AA 7108. Já do ponto de vista tecnológico, é oportuno mencionar o recente trabalho realizado na CBA (Companha Brasileira de Alumínio) por Gianiselle e coautores [11] acerca da homogeneização da AA 7108, indicando interesse da indústria nacional no desenvolvimento e produção dessa liga. 


\section{REVISÃO BIBLIOGRÁFICA}

\subsection{Endurecimento por precipitação - um breve histórico}

O alumínio de elevada pureza é um material bastante dúctil e bom condutor de eletricidade e calor. Dessa forma, suas maiores aplicações são em projetos relacionados a sistemas elétricos e térmicos, além da fabricação de objetos que não necessitem de elevada resistência mecânica, como é o caso das latas para bebidas.

Com o objetivo de se obter materiais leves e de elevada resistência mecânica, foram criadas as ligas de alumínio, cujos principais elementos de liga empregados são $\mathrm{Zn}, \mathrm{Mg}, \mathrm{Cu}, \mathrm{Fe}, \mathrm{Si}, \mathrm{Mn}, \mathrm{Cr}$ e Ti [12]. Elementos como o $\mathrm{Zn}$ e o Mg possuem elevada solubilidade no alumínio, enquanto outros como o $\mathrm{Cu}$ possuem uma solubilidade intermediária. O ganho de resistência mecânica observado nas ligas de alumínio pode ser atribuído aos mecanismos de 1) formação de uma solução sólida cujos átomos de soluto distorcem a rede e, principalmente, 2) precipitação de intermetálicos coerentes que dificultam a movimentação de discordâncias e, por consequência, também dificultam a deformação plástica [13].

O artigo de Polmear [14] apresenta o que é considerado o marco inicial do desenvolvimento das ligas de alumínio de alta resistência. Conta-se que na Alemanha, em 1903, Alfred Wilm procurava por ligas de alumínio que pudessem substituir o latão na fabricação de cartuchos de munição. Após algumas tentativas (frustradas) de aumentar a resistência de ligas do sistema $\mathrm{Al}-\mathrm{Cu}-\mathrm{Mn}$ por meio de aquecimento e resfriamento brusco (como já era comum para os aços), Wilm notou que a dureza das amostras tratadas dessa maneira aumentava quando essas eram deixadas a temperatura ambiente (um fenômeno hoje conhecido como envelhecimento natural). Alguns anos depois, em 1911, os estudos de Wilm que descreviam o fenômeno foram publicados. A Figura 1 apresenta a primeira curva de envelhecimento apresentada nestes trabalhos. 


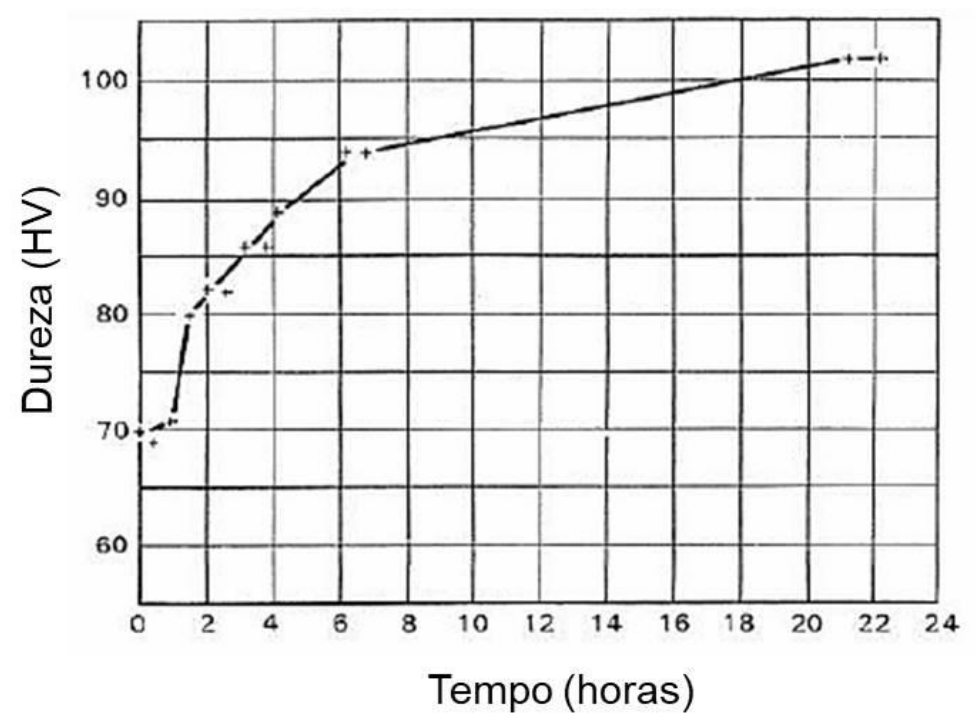

Figura 1 - A primeira curva publicada por Alfred Wilm evidenciando o aumento da dureza de uma liga de Al com o passar do tempo [15]

Após a publicação dos estudos de Wilm, outras ligas metálicas endurecíveis por precipitação (alumínio, cobre e até mesmo aços - os chamados Maraging) começaram a ser desenvolvidas com base neste princípio.

Outro marco histórico importante que vale ser mencionado é o desenvolvimento das ligas Al - Zn - Mg para a fabricação da fuselagem do caça Mitsubishi A6M2 Reisen Zero (1940), a lendária aeronave utilizada pelo exército japonês durante a segunda guerra mundial [16].

Com o advento de técnicas experimentais, como a microscopia eletrônica de transmissão, foi possível constatar que o aumento de resistência observado se dava pela presença de pequenos precipitados intermetálicos dispersos ao longo da matriz. Atualmente, o mecanismo de formação desses precipitados é bastante esclarecido [17], e as ligas de alumínio endurecíveis por esse método são intensamente aplicadas nas áreas de transporte (aéreo e terrestre) em função de suas elevadas resistências específicas. Em outras palavras, tais materiais possuem elevada resistência mecânica combinada com leveza.

\subsection{Mecanismos de endurecimento - uma síntese}

Entende-se por endurecimento, o aumento da capacidade do material em resistir à deformação plástica pela aplicação de tensões. Esse aumento de resistência é, em geral, acompanhado da queda da ductilidade e da tenacidade dos materiais 
endurecidos. O que se busca em materiais de aplicação estrutural é o compromisso entre resistência à deformação plástica e tenacidade à fratura.

Para a obtenção de metais e ligas mais resistentes, existem processos termomecânicos que promovem o ganho de resistência em diferentes níveis por meio de mecanismos diversos. Os principais, detalhados nas seções seguintes, são: Endurecimento por solução sólida, endurecimento por refino de grão, endurecimento por precipitação e endurecimento por encruamento. Em relação ao presente trabalho, dar-se-á atenção especial aos mecanismos de endurecimento por precipitação e por encruamento, pois ambos são responsáveis pela maior parte da parcela do endurecimento das ligas de alumínio da série 7XXX.

\subsubsection{Endurecimento por solução sólida}

Soluções são misturas homogêneas de duas ou mais substâncias. O conceito de solução, amplamente difundido nas áreas de química para tratar das soluções aquosas, pode ser estendido aos materiais e as chamadas soluções sólidas. Dados dois metais distintos, é possível predizer que eles formarão uma solução sólida caso atendam os critérios propostos por Hume-Rothery [18]:

- A diferença entre os raios atômicos do soluto e do solvente deve ser menor que $15 \%$;

- A eletronegatividade dos átomos de soluto e solvente deve ser próxima;

- Ambos os metais devem possuir em dada condição a mesma estrutura cristalina

- As valências dos átomos em questão não devem diferir em mais de uma unidade. O metal de menor valência tende a se dissolver no metal de maior valência.

As regras propostas por Hume-Rothery dizem respeito apenas às soluções sólidas substitucionais. Isto é, soluções em que um átomo do metal hospedeiro (solvente) tem seu lugar na rede cristalina ocupado por um átomo de soluto. Existe também a possibilidade de que átomos pequenos (como carbono e nitrogênio) 
ocupem os interstícios existentes na estrutura de alguns metais, como o ferro. Nesse caso, forma-se a solução sólida intersticial.

A inserção de átomos de soluto causa distorção no arranjo cristalino regular dos metais. Os campos de tensão gerados por essa distorção interagem com as discordâncias e dificultam sua movimentação, causando o chamado endurecimento por solução sólida.

A Figura 2 mostra como o aumento do teor de alumínio (em solução sólida) afeta a dureza das ligas do sistema Al-Mg.

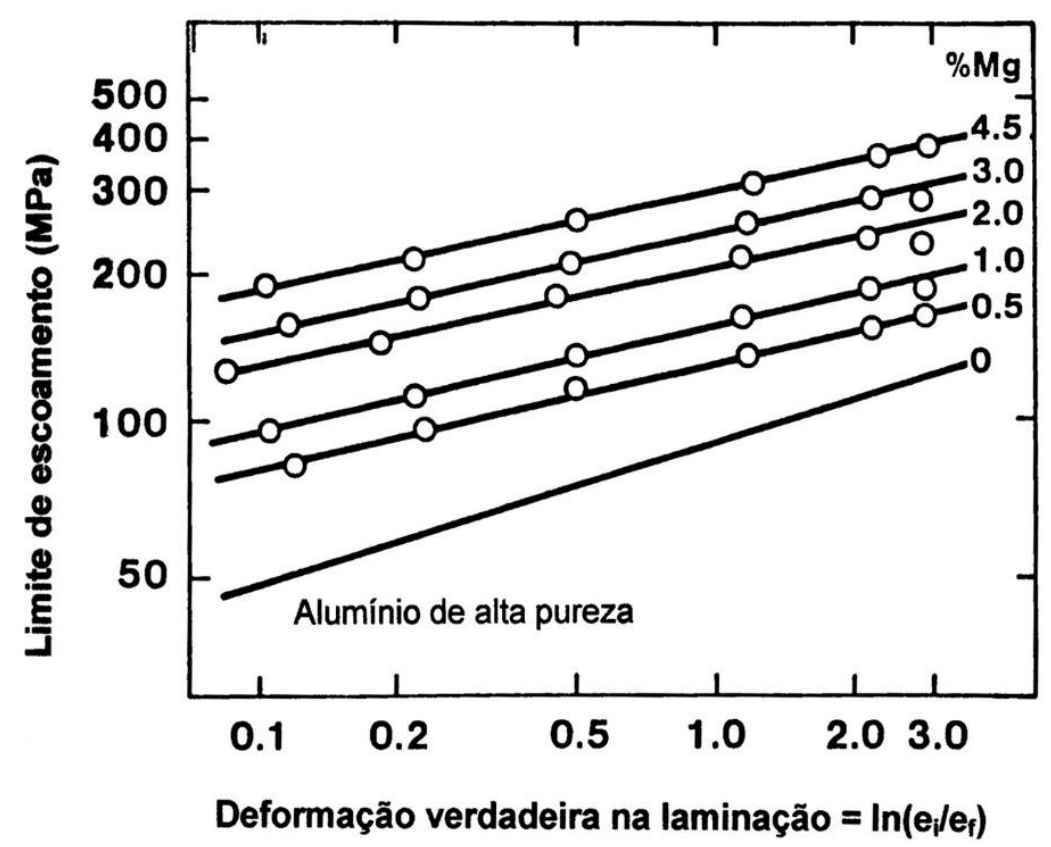

Figura 2 - Influência do teor de Alumínio na dureza das ligas do sistema Al-Mg [19]

A equação abaixo relaciona o aumento da resistência mecânica em termos do limite de escoamento ( $\sigma_{s s}$ ) em função da concentração de soluto em solução sólida[20].

$$
\sigma_{S S}=K \cdot G c^{n}
$$

Onde:

K é uma constante, $G$ é o módulo de cisalhamento, c é a concentração de soluto e $n$ é uma constante que varia entre 0 e 1 , sendo 0,5 o valor mais frequente. 
Embora importante para sistemas como o Al-Mg e o Al-Zn, o endurecimento por solução sólida possui pouca relevância para o alumínio e suas ligas. Isso se deve a baixa solubilidade que a maioria dos elementos de liga possui em uma matriz de Al, conforme indicado na Tabela 1. É importante mencionar ainda que a solubilidade máxima indicada é obtida em temperaturas elevadas, sendo que em relação aos produtos trabalhados (wrought) a temperatura ambiente, tal solubilidade é ainda menor do que a mostrada pela tabela.

Tabela 1 - Solubilidade máxima de alguns elementos de liga no alumínio. Adaptado de [21],[22]

\begin{tabular}{lccc} 
Elemento & Temperatura $\left({ }^{\circ} \mathbf{C}\right)$ & \% peso & \% atômica \\
\hline Cobre & 548 & 5,65 & 2,4 \\
Ferro & 655 & 0,05 & 0,025 \\
Magnésio & 450 & 17,4 & 18,5 \\
Manganês & 658 & 1,82 & 0,9 \\
Silício & 577 & 1,65 & 1,59 \\
Titânio & 665 & 1,3 & 0,74 \\
Zinco & 443 & 82,8 & 66,4 \\
Zircônio & 660 & 0,28 & 0,08 \\
\hline
\end{tabular}

A dificuldade da dissolução de partículas formadas por tais elementos de liga na matriz rica em alumínio pode, por sua vez, ser explicada pela diferença na natureza dos átomos de soluto em relação ao alumínio. Ao analisar a tabela periódica, nota-se que todos os principais elementos de liga mencionados são típicos metais de transição, enquanto o alumínio se encontra na família do boro, juntamente com o gálio e o índio. Isso, por si só, indica que o alumínio deve possuir comportamento químico distinto dos outros metais, o que é refletido na limitação das ligas de alumínio em solubilizar elementos metálicos, conforme indicado na Tabela 1, apresentada anteriormente.

\subsubsection{Endurecimento por refino de grão}

As fronteiras entre grãos em um material policristalino são regiões em que ocorre a transição entre a orientação dos agrupamentos atômicos que compõe tais estruturas. A presença dessas fronteiras, também chamadas de contornos de grão, 
pode ser responsável tanto pelo endurecimento quanto pela queda de resistência de um material metálico. Em temperaturas abaixo da metade do ponto de fusão absoluto e à elevadas taxas de deformação, a presença de numerosos contornos de grão tende a causar o endurecimento do material, já que cada contorno age como uma barreira que dificulta a movimentação de discordâncias. Já em temperaturas elevadas e à baixas taxas de deformação (condições de deformação por fluência), a deformação via difusão e por escorregamento de grãos passa a ser possível, de forma que a resistência mecânica cai [23].

Com exceção de aplicações em elevadas temperaturas, o refino de grão é uma característica desejada nos materiais metálicos, pois grãos menores conferem maior resistência mecânica sem promover a queda da tenacidade [24]. O aumento do limite de escoamento causado pelo refinamento de grão pode ser estimado pela relação proposta de maneira independente por Hall e Petch em meados da década de 50 [25] [26]:

$$
\sigma_{G B}=k D^{-\frac{1}{2}}
$$

Onde $\sigma_{G B}$ é o aumento do limite de escoamento associado à atuação dos contornos de grão como obstáculos, $\mathrm{k}$ é uma constante a ser determinada e $\mathrm{D}$ é o diâmetro médio dos grãos. A relação de Hall-Petch foi inicialmente aplicada no estudo de endurecimento de aços. Mais recentemente, o modelo também tem sido utilizado para descrever o endurecimento por refino de grão em ligas de alumínio [27]. A Figura 3 mostra a curva obtida plotando-se a contribuição do aumento do limite de escoamento associado aos contornos de grão $\left(\sigma_{G B}\right)$ em função do diâmetro médio dos grãos (elevado a 0,5) para a liga $\mathrm{Al}-0,3 \% \mathrm{Cu}$. 


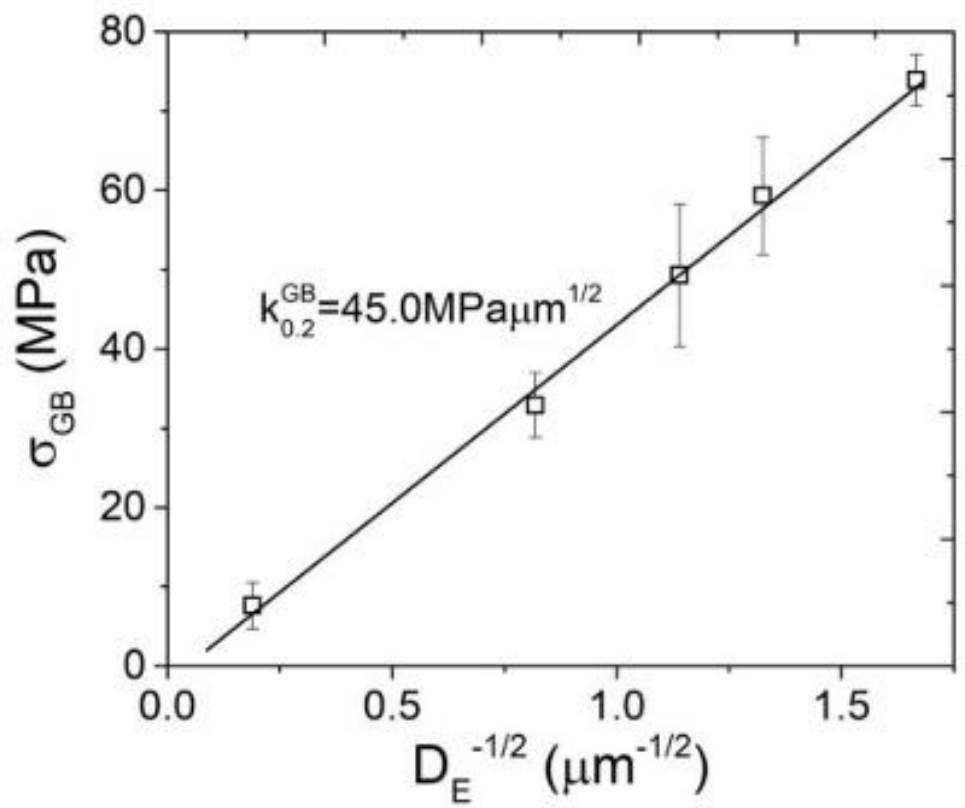

Figura 3 - A contribuição dos contornos de grão no aumento do limite de escoamento plotada em função da raiz quadrada do recíproco do diâmetro médio dos grãos para a liga Al-0,3\%Cu [27]

\subsubsection{Endurecimento por deformação plástica}

Outro mecanismo utilizado para aumentar a resistência mecânica de materiais metálicos é o encruamento, ou endurecimento por deformação plástica. O encruamento será explorado com mais detalhes em tópicos posteriores, juntamente com os fenômenos de recuperação, recristalização e crescimento de grão. Por ora, basta dizer que a deformação plástica de um material metálico causa a multiplicação das linhas de discordância. $O$ aumento da concentração desses defeitos faz com que eles interajam entre si de forma a dificultar a sua movimentação e, por consequência, faz com que a deformação plástica seja dificultada. O fenômeno é usualmente bem descrito por meio da relação matemática proposta por Taylor [28]:

$$
\sigma_{\rho}=\alpha G b \sqrt{\rho}
$$

Onde $\sigma_{\rho}$ é a contribuição do encruamento no aumento do limite de escoamento, $\alpha$ é uma constante que assume valores entre 0,15 e 0,4, G é o módulo de cisalhamento, b é o módulo do vetor de Burgers e $\rho$ é a densidade de linhas de discordâncias contidas no material. 


\subsubsection{Sobre o endurecimento por precipitação nas ligas de alumínio}

O endurecimento causado pela interação dos precipitados com as linhas de discordância já é conhecido há algum tempo. Tal mecanismo é extensamente aplicado na fabricação de diversas ligas metálicas como ligas de cobre [29], aços maraging [30] e superligas de níquel [31]. Com relação ao entendimento dos mecanismos de endurecimento por precipitação, vale mencionar o extenso trabalho de revisão publicado por Kelly e Nicholson [32], que aborda de maneira minuciosa os detalhes envolvidos no aumento de resistência devido à presença de precipitados finos.

Diz-se que uma liga de alumínio endurece por precipitação quando ganha resistência mecânica em função da presença de precipitados intermetálicos. A Figura 4, representa de maneira resumida a classificação das ligas de alumínio de acordo com a Aluminum Association. Nota-se que, dentro do escopo das ligas trabalhadas, apenas metade das séries (2xxx,6xxx,7xxx e 8xxx) são passíveis de serem endurecidas via tratamentos térmicos.

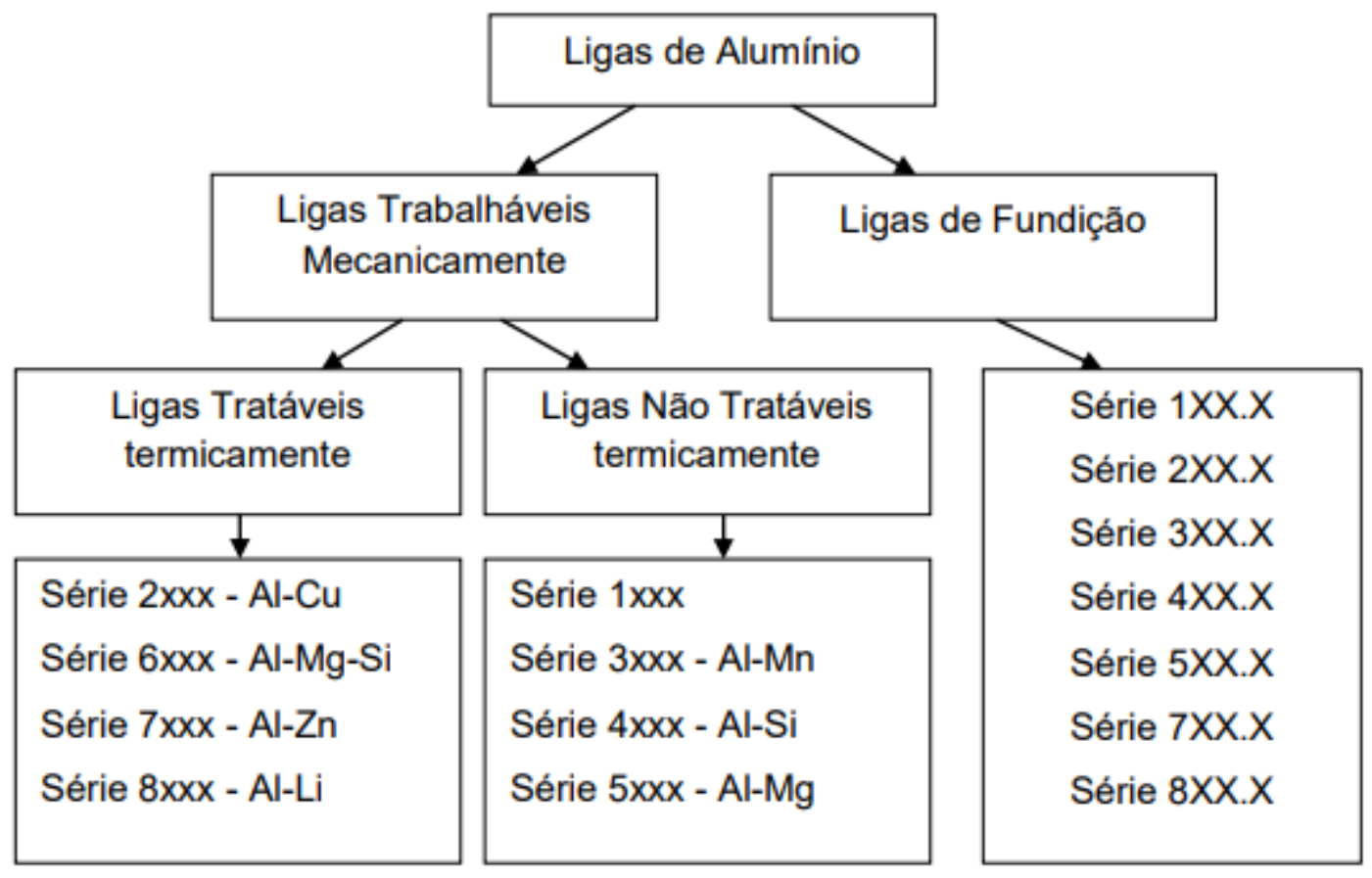

Figura 4 -Fluxograma de classificação das ligas de alumínio conforme a Aluminum Association [33]

As ligas capazes de endurecer por precipitação atendem a dois requisitos: 1) Possuem elementos passíveis de serem totalmente solubilizados na matriz em temperaturas elevadas e 2) tal solubilidade cai drasticamente em temperaturas mais 
baixas. Um exemplo clássico é a liga binária $\mathrm{Al}-\mathrm{Cu}$. A Figura 5 exibe um trecho do diagrama de fases em questão. Uma liga de composição Al - 5\% Cu, por exemplo, atende aos requisitos necessários - O material pode ser solubilizado a $550^{\circ} \mathrm{C}$ (isso é, nessa temperatura existe, no equilíbrio, somente uma solução sólida rica em Al) e essa solubilidade se torna bastante reduzida em temperaturas mais baixas. Após a etapa de solubilização, o material é rapidamente resfriado e retém, de maneira metaestável, a microestrutura relativa à temperatura de solubilização utilizada, isto é, alumínio contendo átomos de cobre em solução sólida. Por fim, a liga solubilizada e rapidamente resfriada é aquecida em uma faixa de temperaturas que compreende $o$ campo bifásico (Al) - $\mathrm{CuAl}_{2}$ para promover o surgimento dessa intermetálico de maneira dispersa ao longo da matriz. Diz-se então que a liga metálica foi envelhecida.

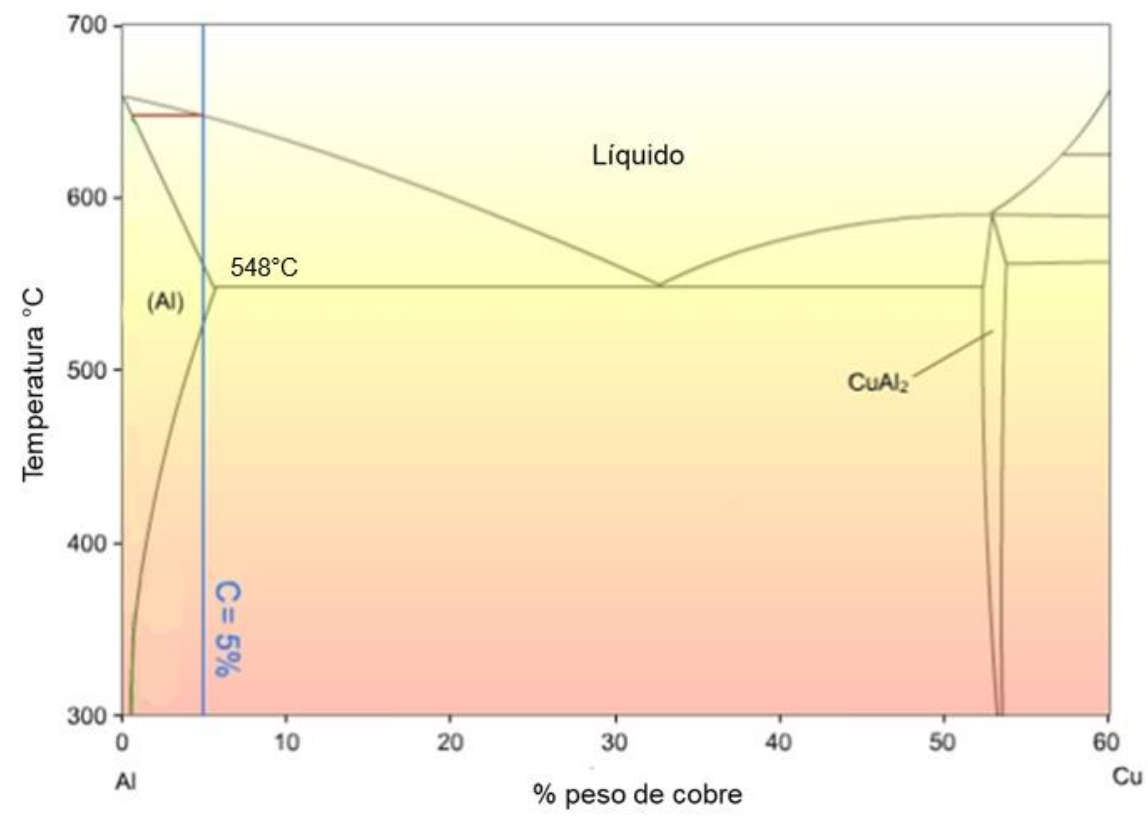

Figura 5 - Diagrama de fases Al - Cu. Adaptado de [34]

O envelhecimento também pode acontecer em temperatura ambiente - 0 chamado envelhecimento natural - ou ser resultante da combinação de etapas mistas que combinem envelhecimento natural e artificial.

\subsubsection{Mecanismo de endurecimento por precipitação coerente}

Meyers e Chawla [35] apresentam dois modelos que explicam o ganho de resistência por meio da interação de discordâncias com precipitados: 1) as linhas de discordância se curvam sobre um precipitado para contorná-lo ou 2) as linhas de 
discordância cisalham o precipitado. A ocorrência de um mecanismo ou de outro depende fundamentalmente do tamanho, distribuição e da natureza do precipitado. Nota-se que em ambas as situações, um acréscimo é necessário promover a movimentação das linhas de discordâncias, conforme detalhado nas próximas seções.

\subsubsection{Partículas contornadas pela pelas linhas de discordância - O mecanismo de Orowan}

O primeiro mecanismo de endurecimento por interação entre discordâncias e precipitados é atribuído a Egon Orowan - Físico e metalurgista que o propôs. Segundo esse mecanismo, se existem partículas de segunda fase transpondo os planos de deslizamento das discordâncias contidas em uma matriz metálica, então uma tensão adicional se faz necessária para fazer com que as linhas de discordância se curvem sobre as partículas e as contornem, deixando para trás anéis de discordâncias que circundam os precipitados. A Figura 6 ilustra o mecanismo proposto por Orowan.

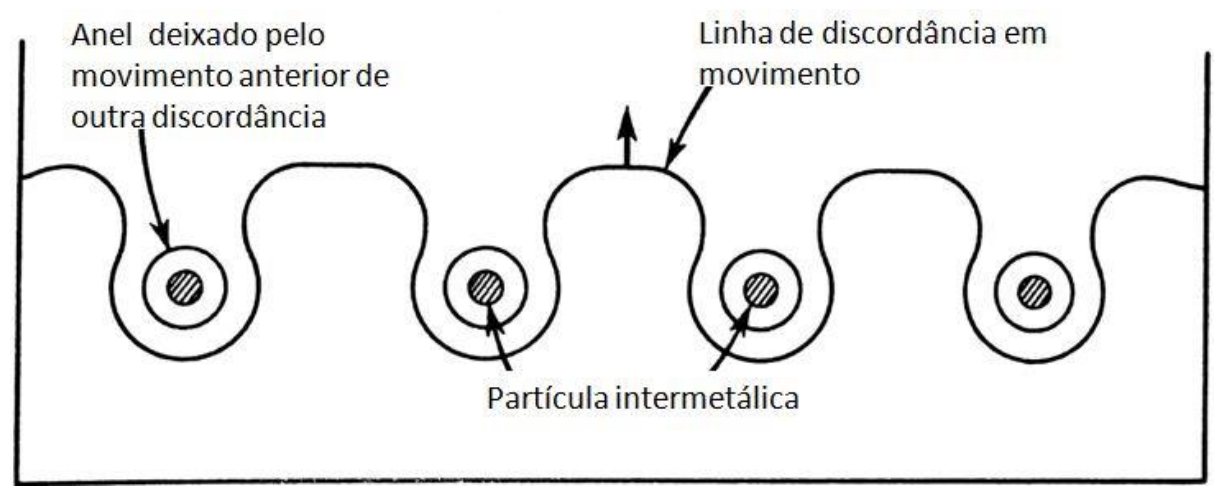

Figura 6 - Mecanismo de Orowan para o movimento de discordâncias através de uma matriz metálica que contém precipitados [36]

O acréscimo na tensão cisalhante necessário para promover a passagem de uma linha de discordância por duas partículas que distam " $x$ " uma da outra é dada por:

$$
\tau_{\text {orowan }}=\frac{G b}{x}
$$

Onde G e b correspondem respectivamente ao módulo de cisalhamento e ao vetor de Burgers da matriz. Dessa forma, caso o mecanismo de Orowan seja atuante, 
a tensão crítica cisalhante para uma liga metálica com precipitados pode ser expressa por:

$$
\tau=\tau_{m}+\frac{G b}{x}
$$

Onde $\tau_{\mathrm{m}}$ corresponde a tensão crítica cisalhante para a matriz na ausência de partículas intermetálicas.

\subsubsection{Partículas cisalhadas pelas linhas de discordância.}

Uma segunda alternativa pela qual as linhas de discordância superam a barreira imposta pela presença de precipitados é através do cisalhamento destes, conforme indicado esquematicamente pela Figura 7.

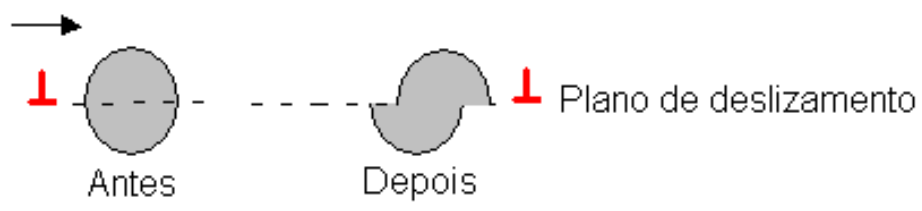

Figura 7- llustração do mecanismo de cisalhamento de precipitado pela passagem de uma linha de discordância.

A tensão adicional necessária para causar o cisalhamento de um precipitado de raio $r\left(\tau_{c}\right)$ pode ser estimada por:

$$
\tau_{c}=\frac{\pi \cdot r \cdot \gamma}{2 . b . x}
$$

Onde $\gamma$ é energia interfacial específica entre precipitado e matriz, $b$ é o vetor de Burgers da matriz e $x$ corresponde ao espaçamento entre partículas.

O mecanismo descrito prevalece em relação ao proposto por Orowan quando a tensão necessária para cisalhar o precipitado $\tau_{c}$ for menor que $o$ valor da tensão necessário para encurvar a linha de discordância sobre este, isto é:

$$
\tau_{c}<\tau_{\text {orowan }}(7)
$$




\subsubsection{Competição entre os mecanismos de Orowan e de cisalhamento de partículas}

No início do envelhecimento, ocorre a formação das zonas de Guinier-Preston (aglomerados formados por algumas centenas de átomos) e, em seguida, surgem precipitados nanométricos ao longo da matriz. Tais precipitados são, em geral, coerentes, dispersos por toda a matriz, e pouco espaçados entre si. Dessa forma, a tensão necessária para a ocorrência do cisalhamento de partículas é menor que a tensão de Orowan, de modo que nesse estágio do envelhecimento as partículas são cisalhadas pela passagem das discordâncias da matriz.

Com a continuidade do envelhecimento, as partículas intermetálicas coalescem e perdem a coerência com a matriz. Dessa forma, a tensão necessária para o cisalhamento dos precipitados aumenta e o mecanismo de Orowan passa a ser predominante.

A Figura 8 ilustra o fenômeno de competição entre os dois mecanismos para partículas de $\mathrm{Al}_{3} \mathrm{Zr}(\mathrm{G}=196 \mathrm{GPa})$ em matriz de solução sólida rica em Al. Há, portanto, um raio ótimo que resulta no máximo aumento da tensão cisalhante crítica.

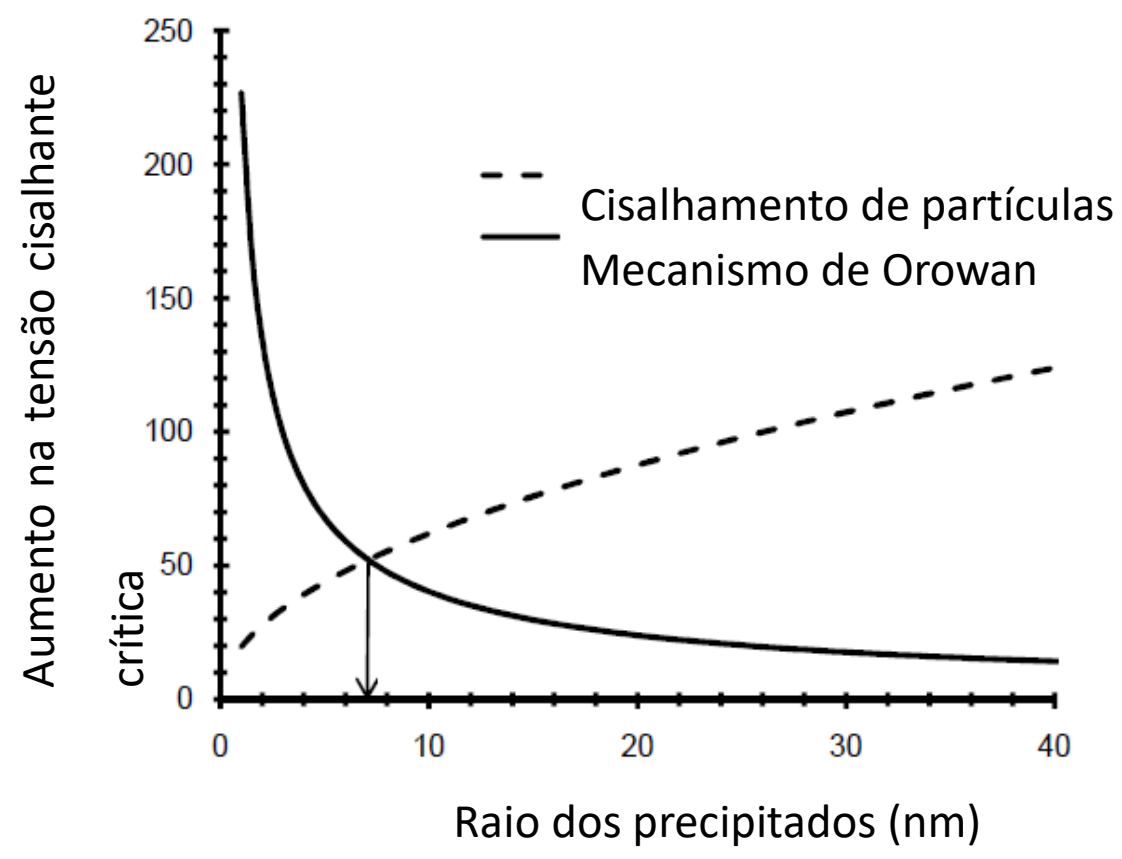

Figura 8 - Competição entre os mecanismos de cisalhamento de partícula e de Orowan. Uma distribuição de precipitados de $\mathrm{Al}_{3} \mathrm{Zr}$ com raio de aproximadamente $7 \mathrm{~nm}$ é a situação ótima, que resulta no maior ganho de resistência em relação ao material da matriz [37] 


\subsection{Tratamentos térmicos aplicados em ligas de alumínio}

Ao contrário do que acontece com boa parte dos aços, o aquecimento seguido de resfriamento brusco (operação denominada têmpera) não resulta em ganho de resistência para as ligas de alumínio. Ao invés disso, o aumento da dureza e da resistência mecânica é obtido pelos tratamentos de envelhecimento, conforme descrito nas seções anteriores.

É comum o uso de códigos para designar os tratamentos térmicos normalmente aplicados às ligas trabalhadas. Alguns tratamentos térmicos e seus respectivos símbolos, designados pela norma NBR 6835, são listados a seguir:

- O: Usado para designar produtos recozidos e, portanto, de menor resistência mecânica.

- W: Solubilizado. Utilizado apenas para produtos passíveis de serem endurecidos por precipitação. O tempo de envelhecimento (sempre a temperatura ambiente) é indicado junto ao símbolo (exemplo: W 10h indica que a liga foi solubilizada e envelhecida naturalmente pelo período de 10 horas).

- T1 - Usado para designar ligas resfriadas bruscamente após conformação a quente e, em seguida, envelhecidas naturalmente até uma condição substancialmente estável.

- T2 - Material resfriado bruscamente após conformação a quente, sendo em seguida trabalhado a frio e envelhecido naturalmente.

- T3 - Material Solubilizado, encruado e envelhecido naturalmente até condição substancialmente estável. Tais produtos possuem resistência mecânica adquirida por meio de encruamento e de precipitação coerente.

- T4 - Aplica-se a produtos solubilizados e envelhecidos a temperatura ambiente. Diferentemente do tratamento T3, as ligas com essa designação não são conformadas após etapa de solubilização.

- T6 - Material solubilizado e envelhecido artificialmente. 
- $\quad$ T7 - Material solubilizado e superenvelhecido. Com esse tratamento a liga adquire menores níveis de dureza e resistência mecânica quando comparada com o tratamento T6. No entanto, essa perda de propriedades é compensada com aumento de resistência à corrosão.

Mais recentemente, outros tratamentos surgiram com o objetivo de obter ligas de elevada resistência mecânica combinada com boa resistência à corrosão. Resultados expressivos foram obtidos por Ranganatha e colaboradores para a liga AA 7049 [38] e por Ozer e Karaaslan para a liga AA 7075 [39]. Em ambos os estudos publicados em 2017 - a combinação de resistência mecânica e resistência à corrosão foi obtida por tratamento térmico denominado retrogression and reaging. Esse tratamento promove envelhecimento da liga de alumínio utilizando altas taxas de aquecimento e omais de uma faixa de temperatura (ou seja, em mais de uma etapa). Esse tipo de tratamento se mostrou eficaz em manter a elevada resistência mecânica das ligas da série 7XXX enquanto aumentam a resistência à corrosão desses materiais. $O$ tratamento térmico em questão é representado de maneira gráfica na Figura 9

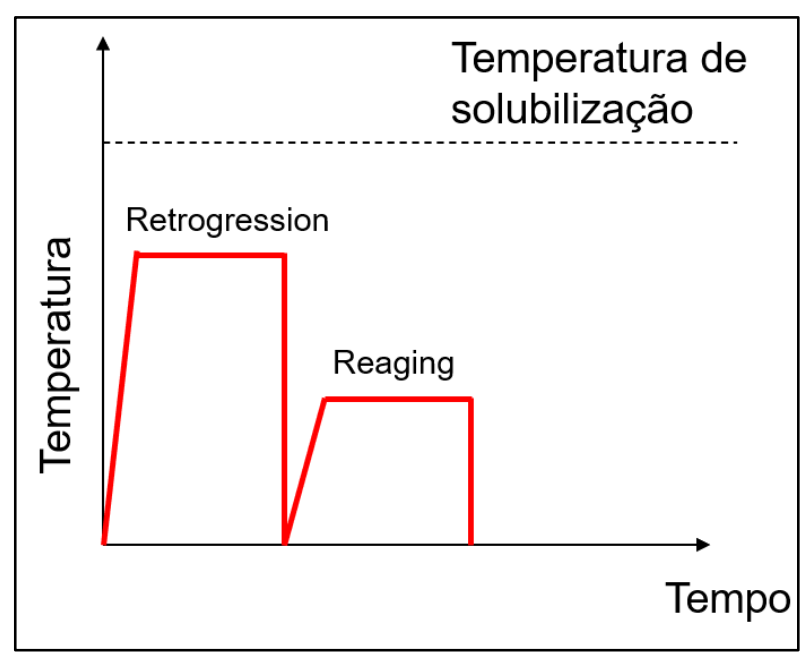

Figura 9 - Representação gráfica esquemática do tratamento térmico denominado Retrogression and Reaging.

\subsection{A liga AA 7108}

A liga AA 7108 é uma liga do sistema ternário Al-Mg-Zn aplicada principalmente na construção de veículos de transporte terrestre, como vagões de trens e guindastes [40]. Pode ser extrudada com elevados graus de redução e em geometrias diversas, além de ser um material conhecido por apresentar um bom compromisso entre 
resistência mecânica e tenacidade. Nota-se, por exemplo, que no estado T6, a AA 7108 possui limite de escoamento médio de $300 \mathrm{MPa}$, um valor intermediário entre a AA 6061 (270 MPa) e a AA 7075 (500 MPa), sem apresentar, no entanto, os problemas da AA7075 relacionados à baixa tenacidade e a tendência a sofrer corrosão sob tensão [33]. A Tabela 2 apresenta algumas propriedades físicas da liga de alumínio AA 7108.

Tabela 2 - Algumas propriedades da liga AA 7108 [40]

\begin{tabular}{ccccc}
\hline $\begin{array}{c}\text { Densidade } \\
\left(\mathbf{k g} / \mathbf{m}^{3}\right)\end{array}$ & $\begin{array}{c}\text { Intervalo de } \\
\text { fusão }\left({ }^{\circ} \mathrm{C}\right)\end{array}$ & $\begin{array}{c}\text { Condutividade } \\
\text { elétrica }(\mathbf{M S} / \mathbf{m})\end{array}$ & $\begin{array}{c}\text { Condutividade } \\
\text { térmica }(\mathrm{W} / \mathbf{m} . \\
\mathrm{K})\end{array}$ & $\begin{array}{c}\text { Módulo de } \\
\text { Young }(\mathrm{GPa})\end{array}$ \\
\hline 2770 & $600-650^{\circ} \mathrm{C}$ & $19-23$ & $130-160$ & 70 \\
\hline
\end{tabular}

A Tabela 3 mostra a composição da AA 7108 segundo especificação da ASTM. Nota-se que o material possui maiores teores de $\mathrm{Zn}$ e $\mathrm{Mg}$ em relação aos demais elementos de liga. A combinação entre ambos os elementos mencionados resulta na formação do composto intermetálico responsável pelo endurecimento ( $\left.\mathrm{MgZn}_{2}\right)$, como será abordado posteriormente. Nesse material, o cobre é considerado uma impureza e seu teor é estritamente controlado [41].

Tabela 3 - Limites de composição para a liga AA 7108 [33]

\begin{tabular}{cccccccccc}
\hline & $\mathrm{Si}$ & $\mathrm{Fe}$ & $\mathrm{Cu}$ & $\mathbf{M n}$ & $\mathbf{M g}$ & $\mathbf{Z n}$ & $\mathbf{Z r}$ & $\mathrm{Ti}$ & $\mathbf{A l}$ \\
\hline $\begin{array}{c}\text { \% em } \\
\text { massa }\end{array}$ & 0,10 & 0,10 & 0,05 & 0,05 & $0,7-1,4$ & $4,5-5,5$ & $0,12-0,25$ & 0,05 & balanço \\
\hline
\end{tabular}

Com relação às fases intermetálicas presentes nas ligas de alumínio, Raghavan [42] e colaboradores as classificam em dispersoides e precipitados finos. Os disperoides são partículas de dimensões entre 0,5 e $2 \mu \mathrm{m}$, em geral insolúveis na matriz, formadas por elementos como $\mathrm{Cr}$, Zr e Ti que são adicionados com propósitos diversos, como retardar a cinética de recristalização ou promover o refino de grão. Já os precipitados finos são partículas muito pequenas (com dimensões de ordem nanométrica), que surgem por meio da realização de tratamentos térmicos (solubilização e envelhecimento), cuja principal função é promover o aumento da dureza do material por meio de sua interação com linhas de discordâncias. 
Conforme mencionado na seção 2.2.1, a grande maioria dos elementos de liga adicionados ao alumínio não possui grande solubilidade em sua rede cristalina. Isso explica, em grande parte, a elevada tendência à formação de intermetálicos (sejam dispersóides ou precipitados finos) apresentada pelas ligas de alumínio. A formação de tais fases depende, principalmente, do coeficiente de difusão (D) dos elementos na rede cristalina do alumínio. A Tabela 4 apresenta o valor de $D$ para alguns elementos de liga do $\mathrm{Al}$ a $470{ }^{\circ} \mathrm{C}$. É importante observar que dispersóides (intermetálicos contendo $\mathrm{Fe}, \mathrm{Si}, \mathrm{Ti}$ e $\mathrm{Zr}$, por exemplo) são geralmente formados durante a solidificação da liga (ou seja, ainda em meio líquido, onde a difusão é facilitada) e que para temperaturas abaixo da linha sólidus, Mg e Zn possuem os maiores coeficientes de difusão entre os elementos apresentados, indicando a tendência à formação de um intermetálico composto por ambos os elementos. 
Tabela 4 - Coeficientes de difusão de alguns elementos em alumínio a $470^{\circ} \mathrm{C}$. Adaptado de [43]

\begin{tabular}{cccc}
\hline Elemento & $\mathbf{D}_{\mathbf{0}}\left(\mathbf{m}^{2} / \mathbf{s}\right)$ & $\mathbf{Q}(\mathbf{k J} / \mathbf{m o l})$ & $\mathbf{D}\left(\mathbf{m}^{2} / \mathbf{s}\right)$ \\
\hline Zinco & $1,1.10^{-5}$ & 93,7 & $2,85 \cdot 10^{-12}$ \\
Magnésio & $1,1.10^{-4}$ & 117,2 & $6,34 \cdot 10^{-13}$ \\
Titânio & $1,12.10^{-1}$ & 260,5 & $5,4 \cdot 10^{-20}$ \\
Zircônio & $7,28 \cdot 10^{-2}$ & 347,0 & $8,6 \cdot 10^{-19}$ \\
Silício & $9,0.10^{-5}$ & 125,6 & $1,3 \cdot 10^{-13}$ \\
Ferro & $4,1.10^{-15}$ & 58,6 & $3,1 \cdot 10^{-19}$ \\
\hline
\end{tabular}

Na liga AA 7108, assim como em grande parte das ligas da série 7XXX, o aumento da resistência mecânica via tratamentos térmicos (solubilização + envelhecimento) ocorre (em grande parte) pela precipitação da fase n' e da fase de equilíbrio $\eta\left(\mathrm{MgZn}_{2}\right)$, segundo a sequência [44]:

$$
\text { Solução Sólida }(\alpha) \rightarrow \text { Zonas GP } \rightarrow \eta^{\prime} \rightarrow \eta\left(M g Z n_{2}\right)
$$

O intermetálico $\eta$ é uma fase de equilíbrio de rede hexagonal com $\mathrm{a}=0,521 \mathrm{~nm}$ e $\mathrm{c}=0,860 \mathrm{~nm}$. Tal como uma fase de equilíbrio, a fase $\eta$ pode ser observada nos diagramas de fase ternários Al-Mg-Zn, conforme mostram as Figuras 10, 11 e 12 secções isotérmicas de temperaturas $460{ }^{\circ} \mathrm{C}, 400{ }^{\circ} \mathrm{C}$ e $25^{\circ} \mathrm{C}$. Nota-se que o intermetálico em questão é formado (para composições com mais de $95 \%$ de Al) em temperaturas abaixo de $400{ }^{\circ} \mathrm{C}$. Isso significa que temperaturas maiores do que (aproximadamente) $400^{\circ} \mathrm{C}$ devem ser utilizadas na etapa de solubilização dessa liga. Comumente são utilizadas temperaturas na faixa de $480^{\circ} \mathrm{C}$ durante 20 ou 30 minutos, dependendo do tamanho das amostras [45], [46]. Já o intermetálico metaestável $\eta$ ', apesar de não ser uma fase de equilíbrio, é o responsável pelo endurecimento máximo observado nas ligas da série 7XXX envelhecidas. 


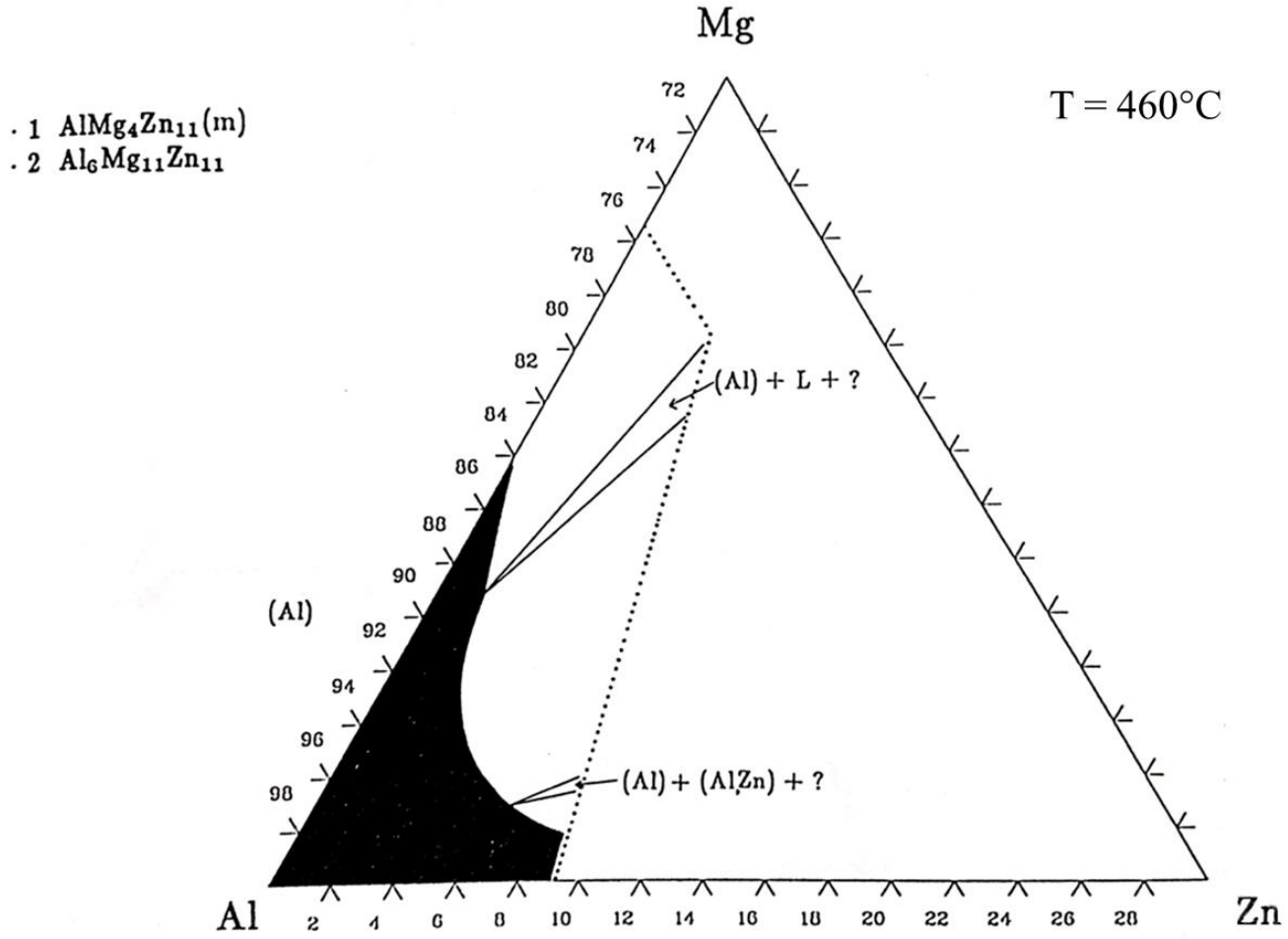

Figura 10 - Secção isotérmica $\left(460^{\circ} \mathrm{C}\right)$ do sistema ternário Al-Zn-Mg [47]

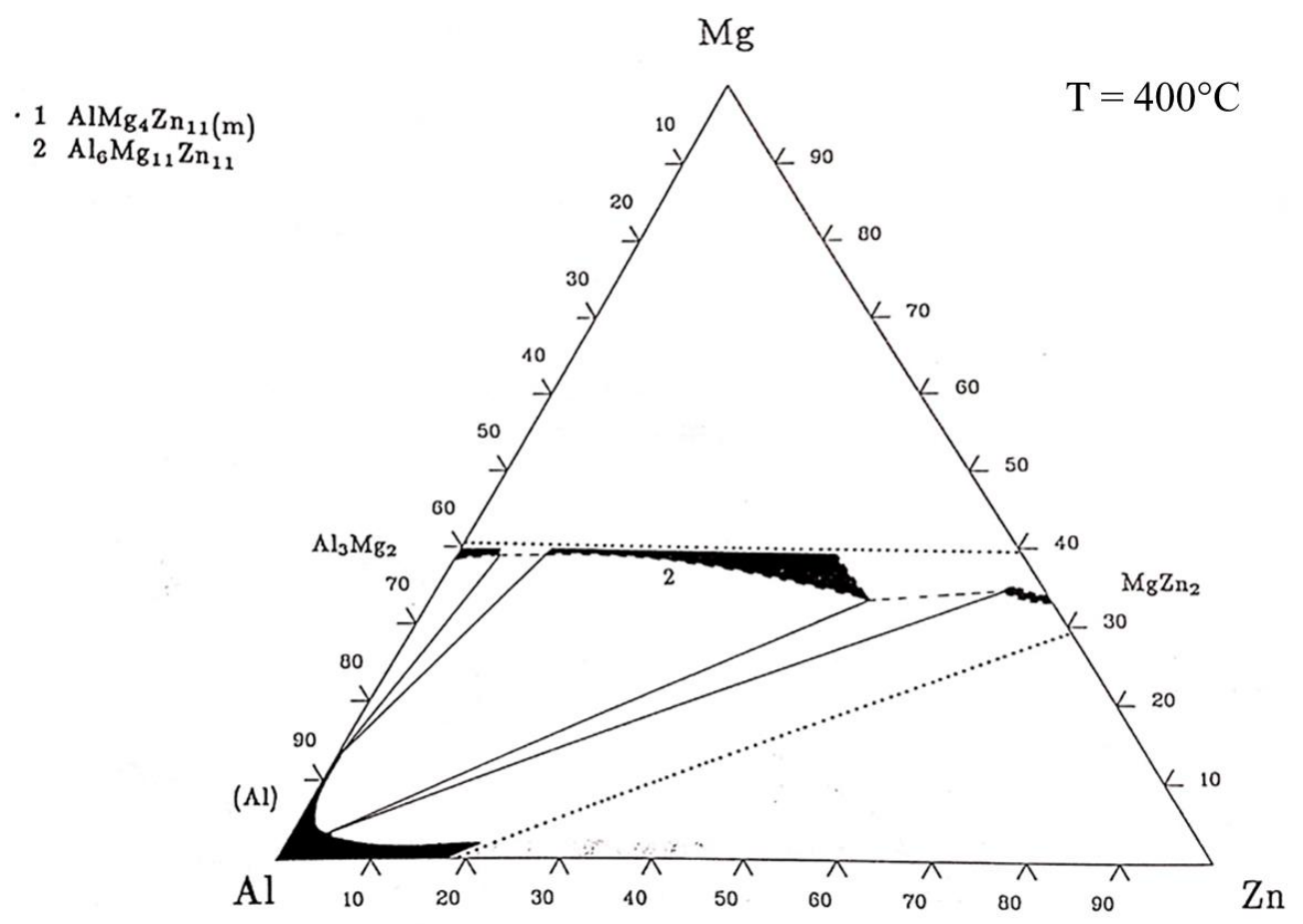

Figura 11 - Secção isotérmica $\left(400^{\circ} \mathrm{C}\right)$ do sistema ternário Al-Zn-Mg [47] 


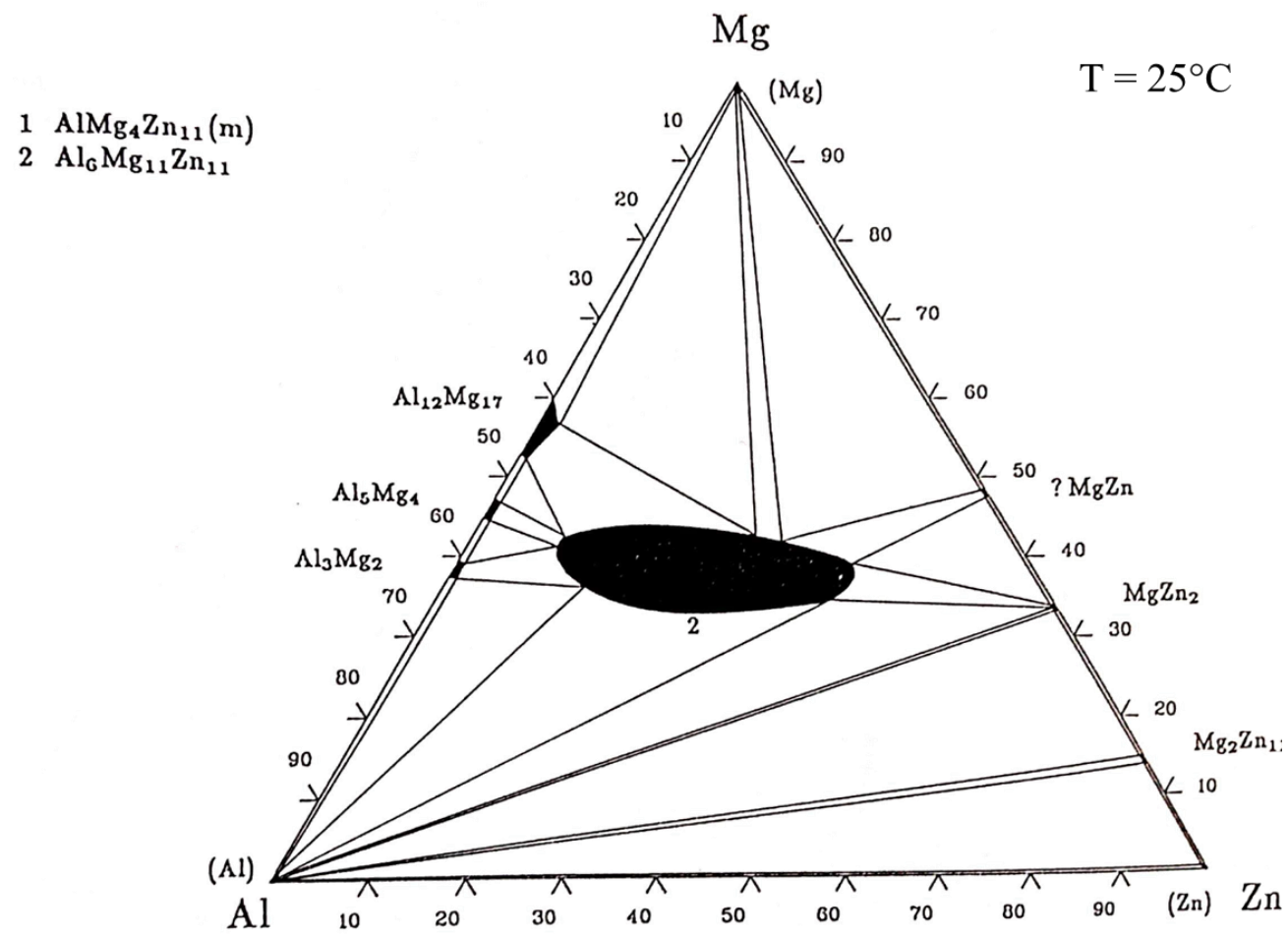

Figura 12 - Secção isotérmica $\left(25^{\circ} \mathrm{C}\right)$ do sistema ternário Al-Zn-Mg [47]

\subsection{Condutividade elétrica do alumínio e suas ligas}

O presente tópico discute o efeito da presença de elementos em solução sólida e de precipitados na condutividade elétrica do alumínio e suas ligas.

A condutividade elétrica $\sigma$ de um material pode ser expressa de acordo com:

$$
\sigma=n \cdot|e| \cdot \mu_{e}
$$

Onde "n" é o número de portadores de carga (os elétrons, para o caso dos metais e ligas), "e" é a carga do elétron e " $\mu_{\mathrm{e}}$ " é a mobilidade dos portadores. A mobilidade depende essencialmente de fatores que atuam como obstáculos ao fluxo de portadores de carga. Assim, a presença de impurezas, as vibrações térmicas e o encruamento são elementos que reduzem a mobilidade dos elétrons e, por consequência, diminuem a condutividade elétrica do material.

Ao analisar os diversos fatores que influenciam a condutividade elétrica dos metais é conveniente considerar a propriedade recíproca, a resistividade elétrica $(\rho)$, que representa a perda de condutividade: 


$$
\rho=\frac{1}{\sigma}
$$

Segundo a regra de Matthiessen, a resistividade total ( $\rho$ total) pode ser representada como sendo a soma de duas contribuições principais, ou seja, vibração da rede $(\rho т)$ dependente da temperatura e resistividade residual $(\rho r)$ causada por impurezas e defeitos cristalinos:

$$
\rho_{\text {total }}=\rho_{T}+\rho_{r}
$$

Medidas de condutividade elétrica são frequentemente utilizadas para acompanhar a precipitação no estado sólido nas ligas de alumínio. As mudanças na condutividade elétrica causadas pela precipitação apresentam dois tipos característicos de comportamento: comportamento clássico e comportamento anômalo. Tais situações são apresentadas nos tópicos 2.5.1 e 2.5.2.

\subsubsection{O caso “clássico" - aumento da condutividade com a formação de precipitados}

O comportamento clássico se caracteriza pelo aumento de condutividade elétrica durante a precipitação. Este tipo de comportamento é explicado pelo aumento da mobilidade eletrônica da matriz causado pela saída de átomos de soluto de solução sólida para formar precipitados, ou seja, o número de obstáculos (átomos) que são utilizados para formar um único precipitado é muito elevado (em muitos casos, da ordem de milhões de átomos) e tem-se como resultado global um aumento da condutividade elétrica. O comportamento clássico é característico das ligas de alumínio não tratáveis termicamente, ou seja, não endurecíveis por precipitação coerente, tais como os alumínios comercialmente puros AA 1050, AA 1070 e AA 1100 [48], as ligas AA 3003 [49] e AA 4006 [50].

\subsubsection{O caso anômalo - o aumento da condutividade após tratamento de solubilização.}

Como mencionado na seção anterior, a presença de impurezas na forma de solução sólida, ou a presença de intermetálicos, distorce a rede cristalina e dificulta a 
passagem de corrente elétrica, diminuindo a condutividade do material (ou, de maneira equivalente, aumentando a resistividade deste). Observa-se, ainda, que a queda da condutividade elétrica tende a ser mais acentuada com a presença de elementos em solução sólida do que com a presença de fases intermetálicas [51]. Isso pode ser compreendido com base na seguinte analogia: É mais fácil chegar até o outro lado de uma sala cheia de cadeiras se estas estiverem "amontoadas" em uma região do que se todas elas estivessem igualmente distribuídas pela sala.

Em alguns casos, em especial quando o envelhecimento é realizado em temperatura ambiente ou em baixas temperaturas, é possível que ocorra o contrário: O material envelhecido apresenta condutividade menor do que o material solubilizado. O fenômeno descrito é, por vezes, tratado como uma anomalia [19].

O comportamento anômalo é caracterizado por uma queda na condutividade nas temperaturas mais baixas de envelhecimento (etapa de pré-precipitação), em muitos casos na temperatura ambiente, seguida por um aumento da condutividade em temperaturas de envelhecimento mais altas (etapa de precipitação). A diminuição da condutividade na etapa de pré-precipitação está associada à formação de aglomerados ("clusters") e zonas de Guinier-Preston (GP) ricos em átomos de soluto $[52,53]$. Os aglomerados contêm apenas centenas de átomos de soluto, mas são mais numerosos e próximos uns dos outros que os precipitados do comportamento clássico. Em outras palavras, a diminuição da mobilidade eletrônica causada pelos aglomerados e zonas GP mais que compensa (em termos da diminuição da mobilidade eletrônica) a saída de solução sólida dos átomos que os formam. A aglomeração de lacunas após o resfriamento rápido a partir da temperatura de solubilização provavelmente contribui para a formação de aglomerados ricos em soluto $[54,55]$. O comportamento anômalo da condutividade elétrica durante o envelhecimento de ligas de alumínio já foi detectado nos sistemas Al-Mg-Si [55-57], Al-Zn [58], Al-Zn-Mg [59] e Al-Zn-Mg-Cu [60].

O entendimento do fenômeno em questão pode ser melhor compreendido com auxílio dos diagramas esquemáticos de energia livre e de equilíbrio de uma liga binária composta pelas fases de equilíbrio $\alpha$ e $\beta$ e pelas fases metaestáveis $\beta$ ' e $\beta$ " (que podem representar, por exemplo, um precipitado metaestável ou um aglomerado de 
centenas de átomos). As Figuras 13 e 14 mostram, respectivamente, os mencionados diagramas. Na Figura 13 é possível observar a que tendência à formação de fases metaestáveis está relacionada ao aumento da quantidade de elementos de liga. Isso explica a tendência das ligas de alumínio com maior teor de elementos (como as da série $2 X X X, 6 X X X$ e 7XXX) em formar intermetálicos metaestáveis.

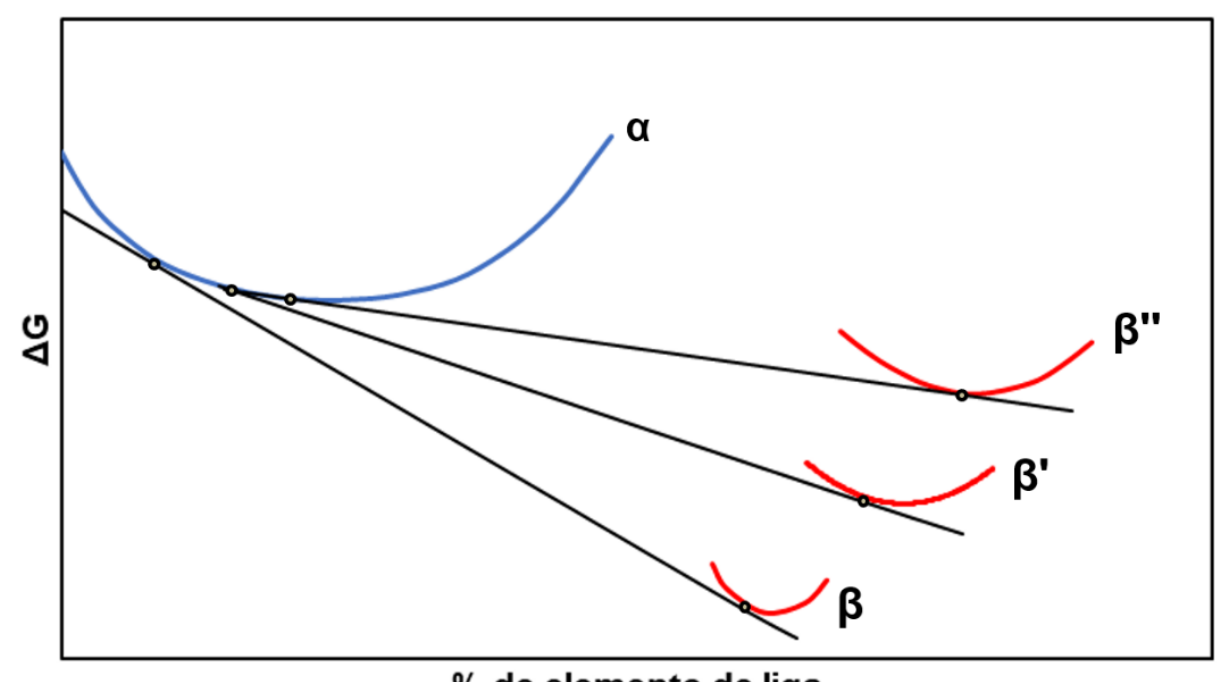

$\%$ de elemento de liga

Figura 13 - Diagrama genérico de energia livre de Gibbs por composição. Adaptado de [61]

As linhas tracejadas do diagrama de fases da Figura 14 indicam que a tendência à formação de fases metaestáveis também está relacionada a temperaturas mais baixas. Em outras palavras, o resfriamento rápido pós solubilização e o envelhecimento natural, junto ao elevado teor de elementos de liga, favorecem o aparecimento de fases metaestáveis.

Nesse ponto é importante ressaltar que o termo 'fases metaestáveis' é usado para se referir aos percussores metaestáveis das fases intermetálicas, como por exemplo a fase $\theta$ ' para as ligas da série 2XXX e a fase n' para as ligas da série 7XXX. Os percursores das mencionadas fases metaestáveis são, por sua vez, constituídos por um aglomerado de centenas de átomos de dimensão que formam regiões denominadas zonas de Guinier -Preston [62]. 


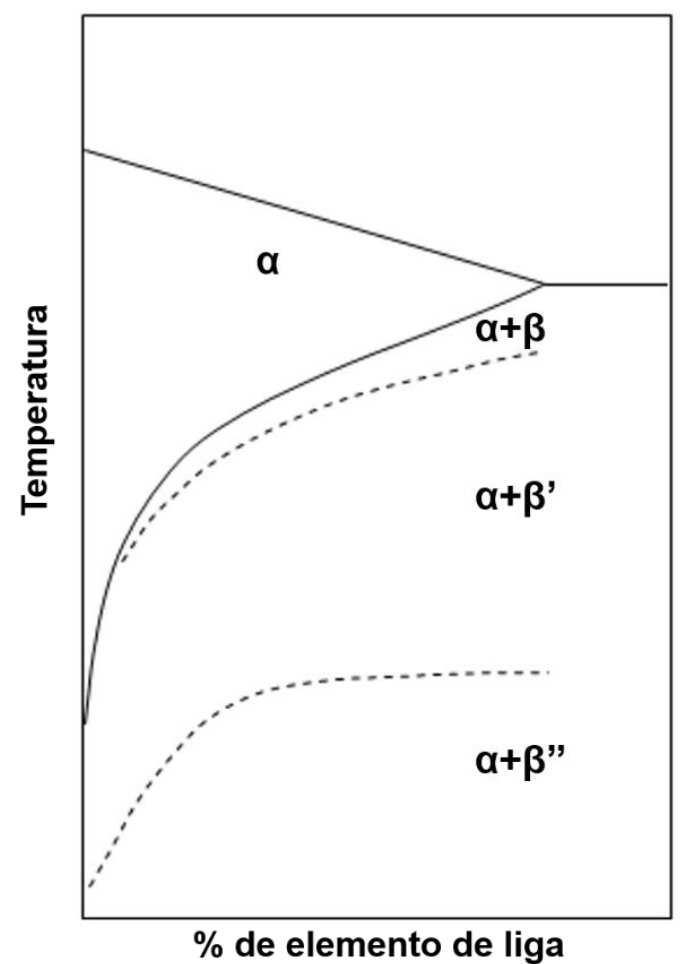

Figura 14 - Diagrama de equilíbrio genérico indicando regiões de tendência à formação de intermetálicos estáveis e metaestáveis. Adaptado de [61].

Dessa forma, é possível concluir que a anomalia observada após a etapa de solubilização está relacionada à formação das zonas GP, de forma que tais zonas surgem preferencialmente em ligas com elevados teores de elementos de liga e a baixas temperaturas (como é o caso das ligas que envelhecem a temperatura ambiente) [19]. É possível inferir que para tais materiais:

$$
\mu_{e}(G P)<\mu_{e}(S S)
$$

Onde " $\mu_{\mathrm{e}}(\mathrm{GP})$ " é a mobilidade dos portadores de carga em de uma liga contendo zonas de Guinier-Preston e " $\mu_{\mathrm{e}}(\mathrm{SS})$ " é a mobilidade dos portadores de carga em uma liga contendo elementos em solução sólida supersaturada.

A Figura 15 mostra curvas esquemáticas, adaptadas do trabalho de Panseri e Federighi (1968), de envelhecimento de uma liga de alumínio endurecível por precipitação coerente. Em relação às curvas isotérmicas, nota-se (conforme colocado anteriormente) que temperaturas de envelhecimento mais baixas tendem a promover o comportamento anômalo. 


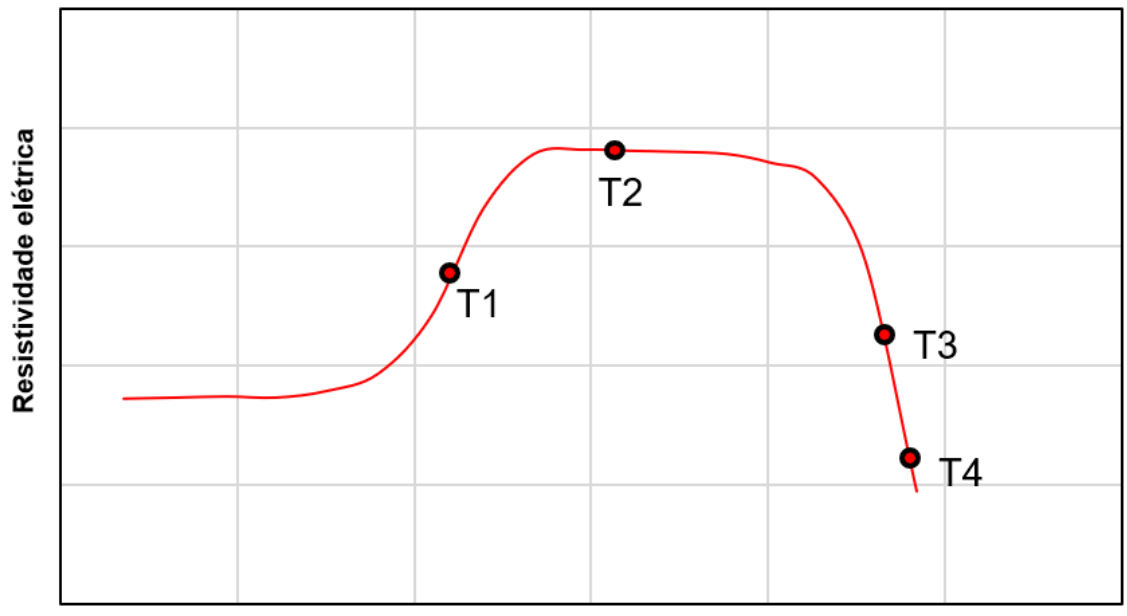

Temperatura

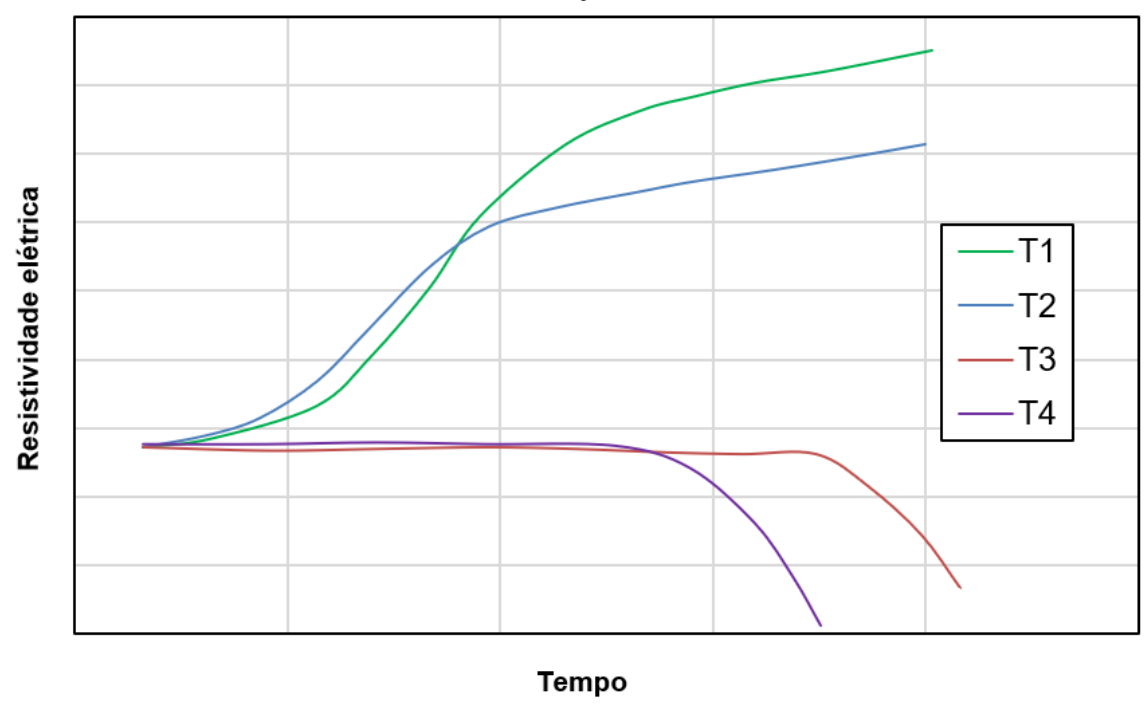

Figura 15 - Curvas esquemáticas - isócrona (acima) e isotérmicas (abaixo) - de envelhecimento de uma liga de alumínio termicamente tratável. Na legenda, T1 $<$ T2 $<$ T3 $<$ T4. Adaptado de [55]

\subsection{Extrusão dos materiais metálicos}

Extrusão é o processo de conformação mecânica que faz uso de uma ferramenta (matriz) pela qual um tarugo metálico é forçado a passar por meio da aplicação de pressão e uso de temperaturas elevadas. A Figura 16 ilustra o processo de extrusão. 


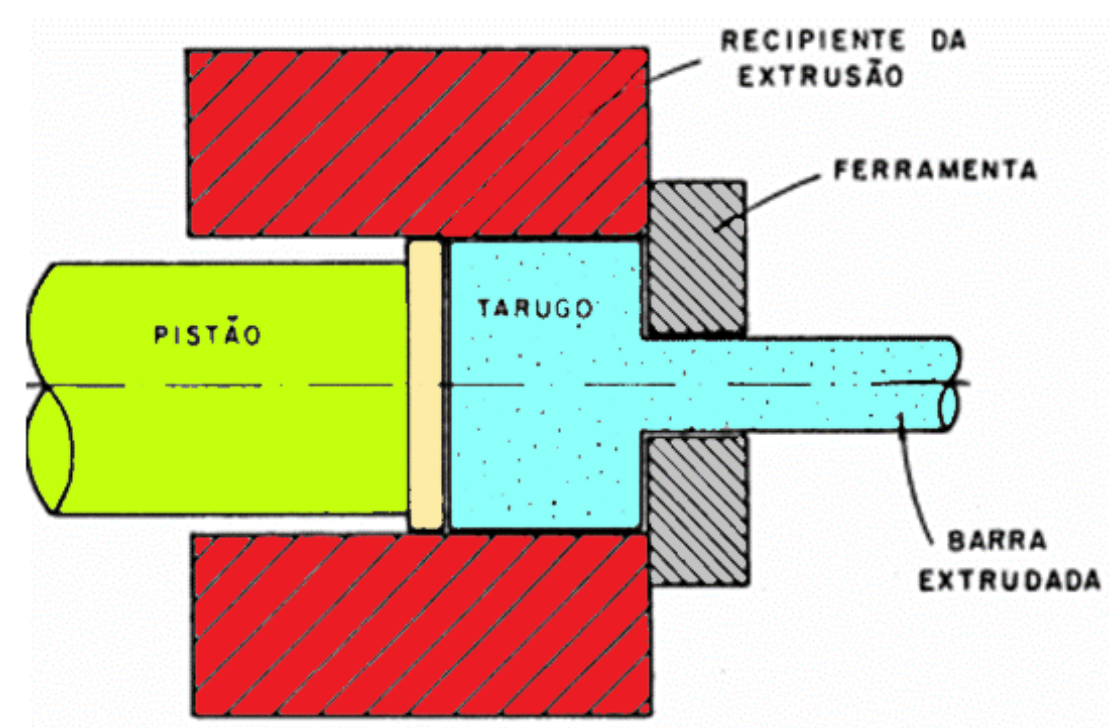

Figura 16 - Representação esquemática do processo de extrusão. Adaptado de [63]

Os produtos extrudados podem assumir diversas formas - desde barras maciças e geometrias tubulares até perfis vazados. Os produtos extrudados são amplamente usados na construção civil e na construção de veículos de transporte. A Figura 17 ilustra a grande variedade de geometrias passíveis de obtenção por meio de extrusão.

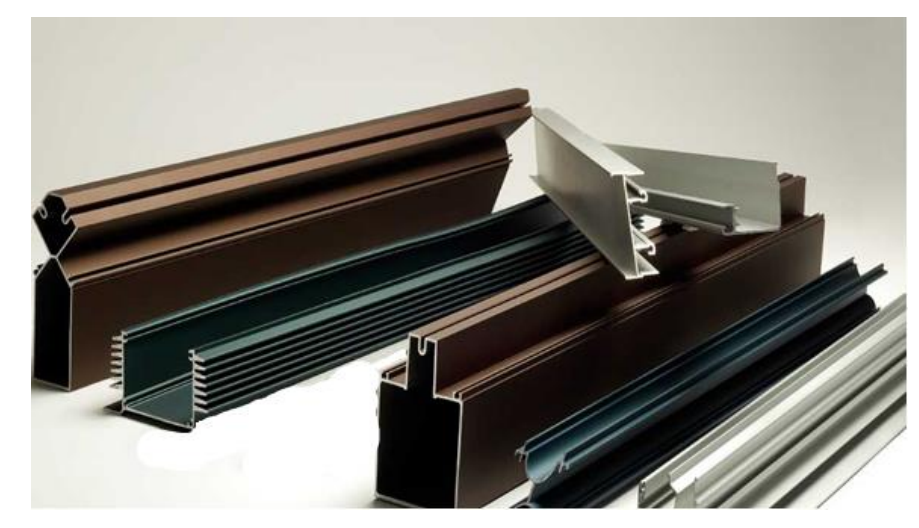

Figura 17- Exemplos de produtos obtidos por extrusão do alumínio e suas ligas [64]

\subsection{Laminação dos materiais metálicos}

O processo de laminação consiste na passagem do material entre dois cilindros rotativos, de forma a reduzir a espessura da chapa ou tira. A Figura 18 esquematiza o processo de laminação. 


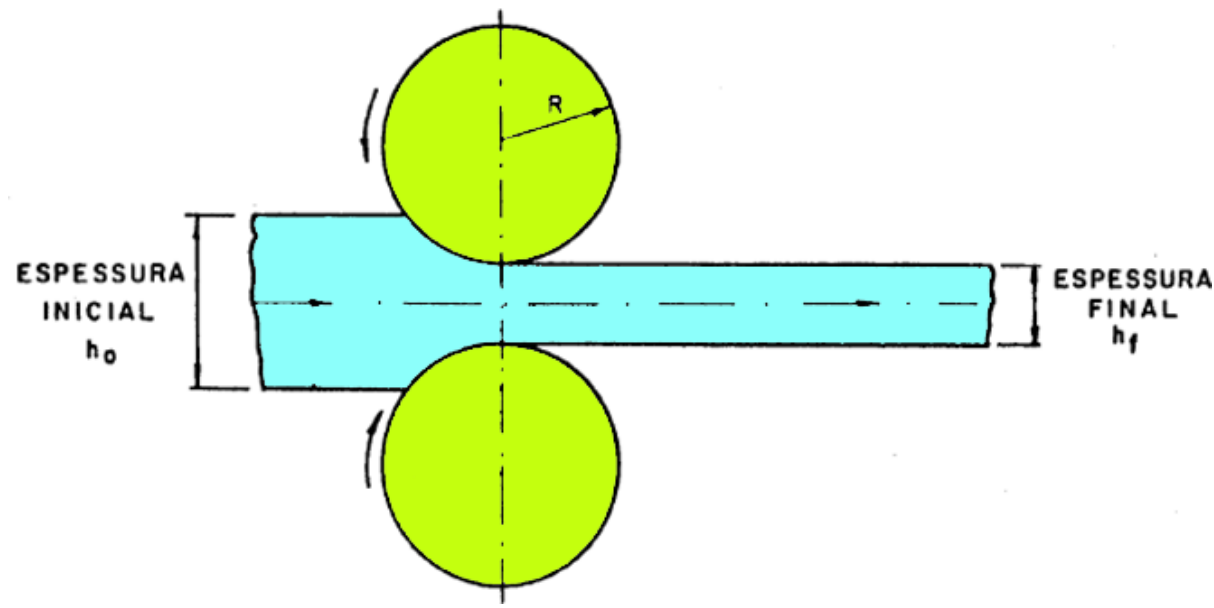

Figura 18 - Representação esquemática do processo de laminação de materiais metálicos. Adaptado de [63]

Em geral, atinge-se a redução almejada por meio de uma sequência de passes que podem ser realizados à temperatura ambiente ou mediante $o$ aquecimento prévio do material. O processo de laminação apresenta bom controle dimensional e elevada produtividade (quando comparado ao forjamento, por exemplo) em função de sua continuidade [65].

Por meio da laminação do alumínio, são produzidas chapas de espessuras diversas, bobinas e folhas. Esses produtos podem ser remanufaturados para a produção de diversos itens como calhas, carrocerias para ônibus e embalagens. A Figura 19 mostra alguns exemplos de produtos de alumínio laminados.
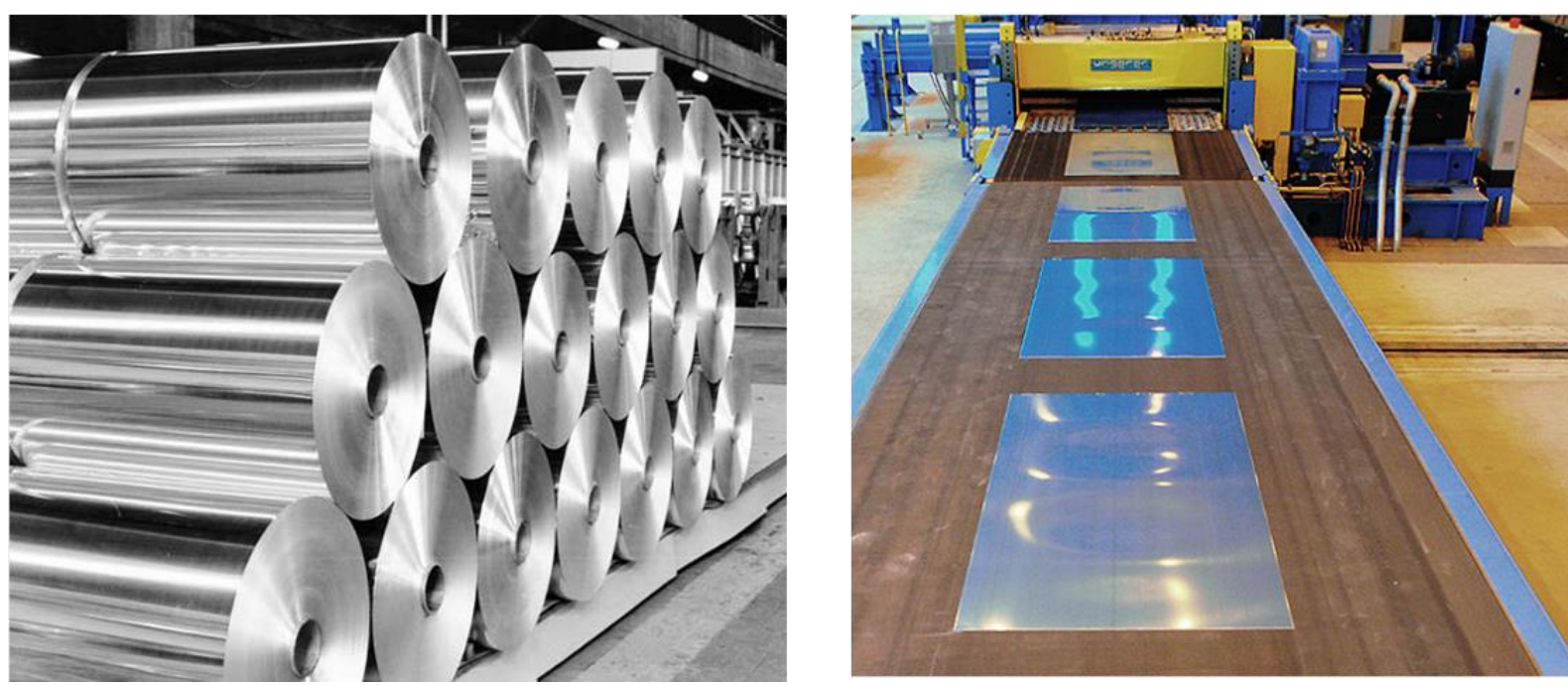

Figura 19 - Exemplos de produtos (bobinas e chapas) de alumínio e suas ligas obtidos por laminação [64] 


\subsubsection{Relações geométricas na laminação de planos}

A Figura 20 indica dois dos principais parâmetros geométricos utilizados no estudo da deformação via laminação: $O$ arco de contato $(A C)$ e o ângulo de contato $(\alpha)$.

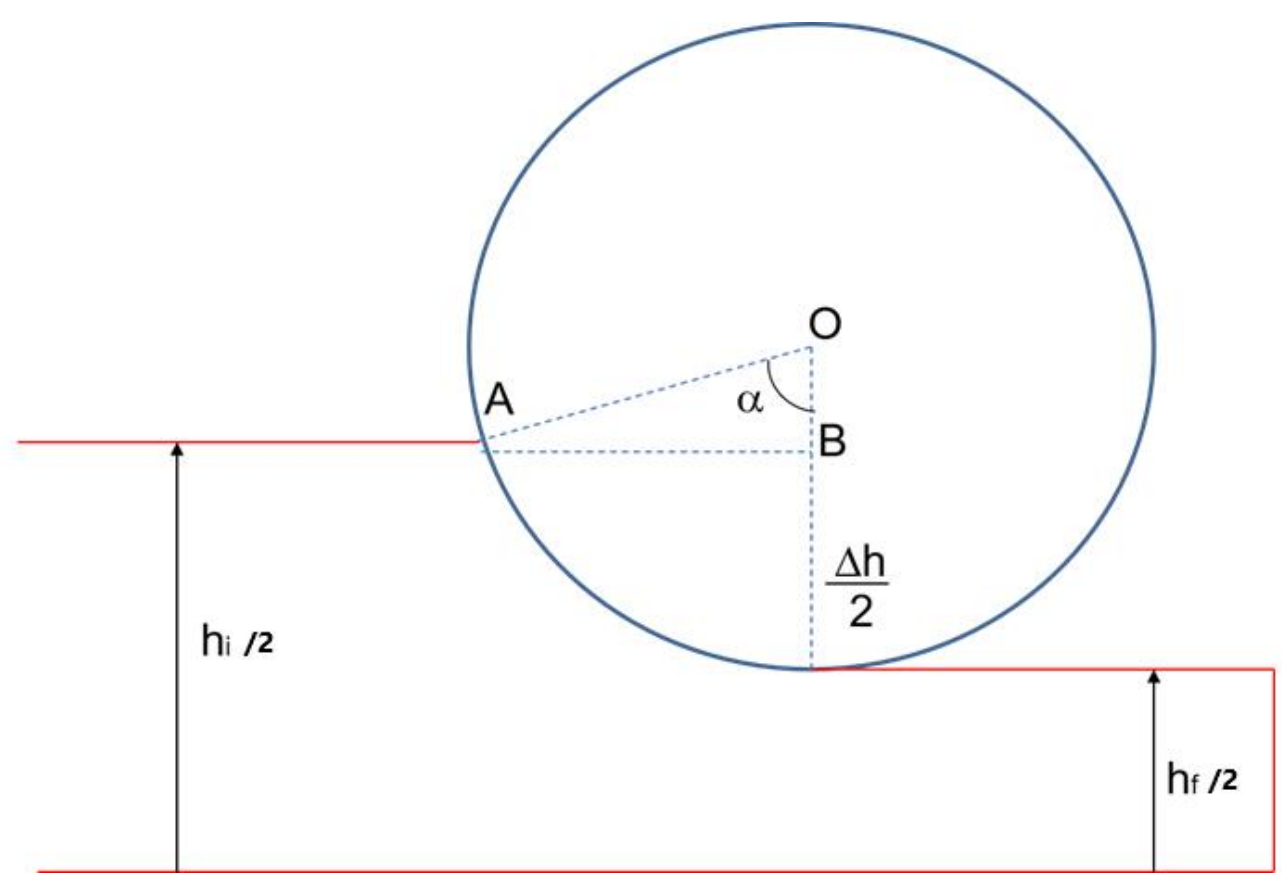

Figura 20 - Principais parâmetros geométricos associados à laminação de planos. Adaptado de [65]

Como o raio $(R)$ dos cilindros de laminação é, em geral, muito maior que a espessura das chapas, é possível aproximar o comprimento do arco pela projeção horizontal (AC). Dessa forma, a partir do triângulo ABO:

$$
L^{2}=(A O)^{2}-\left(B O^{2}\right) \rightarrow L=\sqrt{R^{2}-\left(R-\frac{\Delta h}{2}\right)^{2}} \rightarrow L=\sqrt{R \Delta h-\frac{\Delta h^{2}}{4}}
$$

Usando novamente a justificativa de que $\mathrm{R}>>\mathrm{h}_{\mathrm{i}}$, é possível desconsiderar o termo $\Delta \mathrm{h}^{2} / 4$ dentro do radical e escrever:

$$
L=\sqrt{R \Delta h}
$$

Já o ângulo de contato $(\alpha)$ pode ser estimado pela análise do triângulo $A B O$ por:

$$
\operatorname{sen} \alpha=\frac{L}{R}
$$

Utilizando a relação obtida para o comprimento do arco de contato: 


$$
\operatorname{sen} \alpha=\frac{\sqrt{R \Delta h}}{R}
$$

Multiplicando numerador e denominador por $\mathrm{R}^{1 / 2}$ :

$$
\operatorname{sen} \alpha=\frac{\sqrt{R \Delta h}}{R} \frac{\sqrt{R}}{\sqrt{R}}=\frac{R \sqrt{\Delta h}}{R \sqrt{R}} \rightarrow \operatorname{sen} \alpha=\sqrt{\frac{\Delta h}{R}}
$$

\subsubsection{O fator delta}

O fator delta $(\Delta)$ é um parâmetro calculado a partir de quatro variáveis de laminação: $O$ diâmetro dos cilindros (D), a espessura de entrada ( $\left.h_{0}\right)$, a espessura de saída $\left(\mathrm{h}_{\mathrm{f}}\right)$ e o arco de contato. $\mathrm{O}$ cálculo do fator delta é feito por meio da equação, apresentada no trabalho de Aguiar [66] :

$$
\Delta=\frac{h_{0}+h}{\text { arco de contato }}
$$

E o arco de contato pode ser calculado como:

$$
\text { arco de contato }=\sqrt{\frac{D\left(h_{0}+h\right)}{2}}
$$

Valores de $\Delta$ menores que 1 indicam que o estado de deformação imposto se aproxima de um estado homogêneo, não havendo, dessa forma, um significativo gradiente de deformação entre a superfície e o centro das chapas ou tiras laminadas [67].

\subsection{Recozimento}

Recozimento é o tratamento térmico que tem como finalidade reduzir a dureza e aumentar a tenacidade de materiais previamente deformados. Após ser submetido a uma ou mais etapas de conformação mecânica, a microestrutura dos materiais metálicos se altera - A geometria dos grãos muda e, dependendo dos parâmetros de conformação, ocorre intensa multiplicação de defeitos microestruturais, especialmente discordâncias. Tais alterações mudam as propriedades dos metais, tendendo a aumentar sua dureza e limite de escoamento as custas da redução da 
tenacidade e da ductilidade. Os próximos itens discutirão com mais detalhes a microestrutura resultante do estado encruado (deformado) e os fenômenos que podem ocorrer durante o tratamento térmico de recozimento - recuperação, recristalização e crescimento de grão.

\subsection{Estado encruado}

Ao aumento da resistência mecânica em função da deformação plástica dá-se o nome de encruamento. Um material metálico encruado ganha resistência mecânica que se manifesta pelo aumento da dureza, do limite de escoamento e do limite de resistência à tração. Por outro lado, esse ganho de resistência é acompanhado pela queda da tenacidade e da ductilidade, fatores que fragilizam o material e dificultam sua posterior conformação mecânica.

Sabe-se que a maior parte da energia dispendida para deformar plasticamente um metal é dissipada na forma de calor. De acordo com Kapoor e Nasser (1998), alguns metais podem apresentar um aumento de temperatura de até $90^{\circ} \mathrm{C}$ quando deformados a taxas da ordem de $10^{3} \mathrm{~s}^{-1}[68]$. Dessa maneira, apenas uma pequena porção da energia empregada no processo de deformação é armazenada no material na forma de defeitos cristalinos, principalmente discordâncias. Essa energia retida na forma de defeitos é justamente a força motriz para a ocorrência dos fenômenos que acontecem durante o recozimento. Uma boa estimativa do aumento energia armazenada pode ser feita pela relação:

$$
\Delta E=\frac{\Delta \rho G b^{2}}{2}
$$

Onde $\Delta E$ é a variação da energia armazenada na forma de defeitos, $\Delta \rho$ é a variação da densidade de discordâncias, $\mathrm{G}$ é o módulo de cisalhamento do material e b é o vetor de Burgers.

\subsubsection{Fatores que afetam a distribuição e a densidade de defeitos após deformação}

A microestrutura resultante dos processos de deformação plástica possui energia interna mais elevada em relação àquela associada ao material recozido. 
Apesar disso, a microestrutura do material deformado plasticamente é, em geral, retida de maneira metaestável a temperatura ambiente. A razão para tal é que o rearranjo e a aniquilação das discordâncias são fenômenos termicamente ativados e pouco prováveis de ocorrer à temperatura ambiente para a grande maioria dos metais e ligas.

A concentração e a distribuição dos defeitos cristalinos em um metal deformado dependem das propriedades do material estudado - como a energia de defeito de empilhamento (EDE) - e de parâmetros de processamento adotados - como a temperatura e velocidade de deformação.

De forma geral, é possível afirmar que fatores que aumentam a mobilidade das discordâncias (elevada EDE, altas temperaturas de deformação e taxas de deformação mais baixas) tendem a promover uma estrutura de discordâncias denominada celular - um arranjo de menor energia associada. Por outro lado, fatores que promovam a redução da mobilidade das discordâncias tendem a gerar uma distribuição mais homogênea desses defeitos ao longo da microestrutura do material. A Figura 21 mostra micrografias (obtidas por microscopia eletrônica de transmissão) de amostras de cobre $\left(E D E=62 \mathrm{~mJ} / \mathrm{m}^{2}\right)$ e alumínio $\left(E D E=163 \mathrm{~mJ} / \mathrm{m}^{2}\right)$, ambos de elevada pureza e deformados plasticamente. É possível notar a diferença entre a distribuição das linhas de discordância para os dois materiais: Enquanto no cobre a distribuição é bastante homogênea, para o alumínio existe a tendência de formação de arranjos celulares formados por paredes de discordâncias que circundam áreas com baixa concentração desses defeitos. 


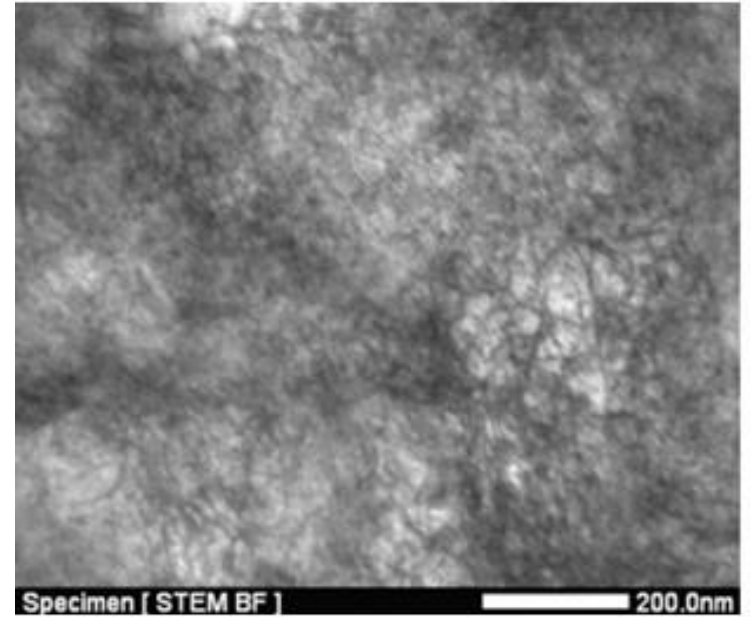

(a)

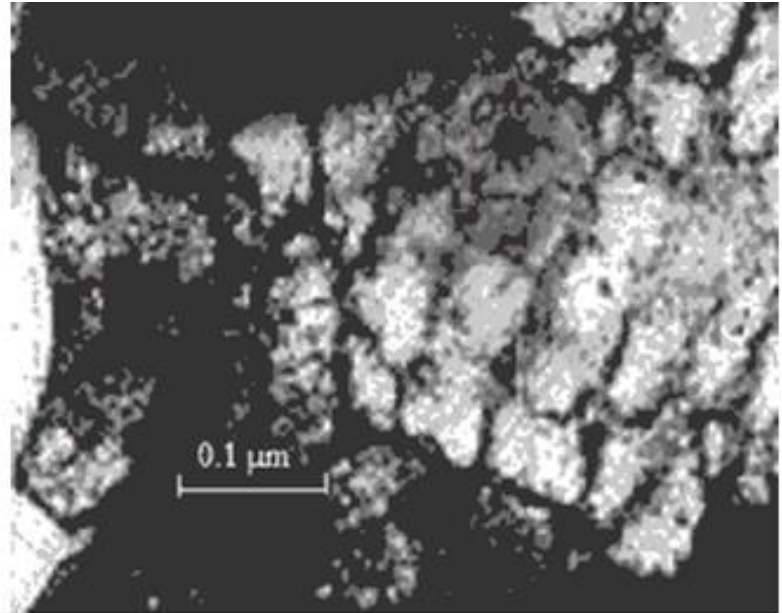

(b)

Figura 21 - Micrografias obtidas via microscopia eletrônica de transmissão de amostras de (a) cobre [69] e (b) alumínio [70], ambos de elevada pureza deformados plasticamente.

\subsection{Recuperação}

A recuperação consiste na restauração parcial da ductilidade e da tenacidade de um material deformado devido à aniquilação e rearranjo de discordâncias. De maneira geral, o fenômeno da recuperação pode ser dividido em etapas de modo a facilitar sua compreensão:

a) As discordâncias geradas por processos prévios de conformação mecânica sofrem aniquilação por meio de dois mecanismos: (i) $O$ encontro de duas discordâncias tipo cunha de sinais opostos em um mesmo plano de deslizamento e (ii) a combinação de escorregamento com desvio em discordâncias do tipo hélice com vetores de Burgers opostos. A aniquilação de discordâncias acontece para temperaturas homólogas na faixa de 0,2 a 0,3 Tf, sendo $\mathrm{Tf}$ a temperatura de fusão absoluta [71]. A Figura 22 ilustra esquematicamente situações nas quais duas discordâncias do tipo cunha (com vetores de Burgers paralelos) podem se aniquilar mutuamente para formar um cristal perfeito e um aglomerado de lacunas, respectivamente. 

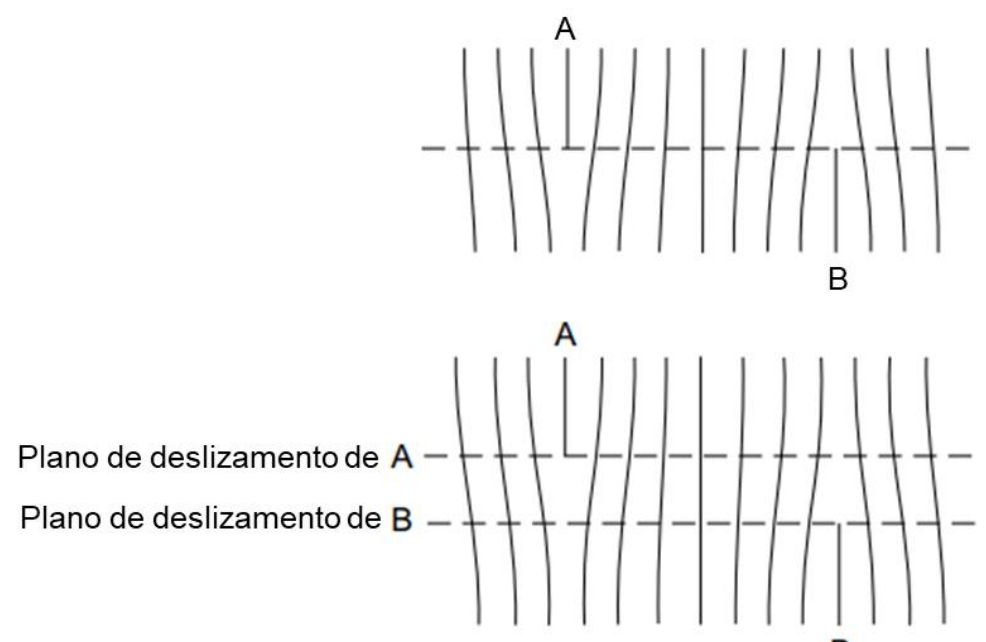

B

Figura 22 - Esquema ilustrando possíveis mecanismos de aniquilação de discordâncias - Adaptado de [72]

b) Caso as discordâncias não aniquiladas pela etapa anterior possuam mobilidade suficiente, ocorre então a formação de estruturas denominadas subgrãos ou contornos de grão de baixo ângulo. Na ausência de tensão externa aplicada, a formação de subgrãos requer temperaturas acima de 0,4 Tf, o que confere às discordâncias mobilidade suficiente para a ocorrência dos mecanismos de escorregamento com desvio e escalada [71]. A Figura 23 mostra uma micrografia obtida por MET para uma amostra deformada de alumínio de alta pureza (a) que foi em seguida recozida a $250^{\circ} \mathrm{C}$ por 120 segundos (b). É possível observar que as paredes das células de discordância, espessas e pouco ordenadas, sofrem rearranjo de modo a ficar mais bem definidas e resultando na estrutura celular. 

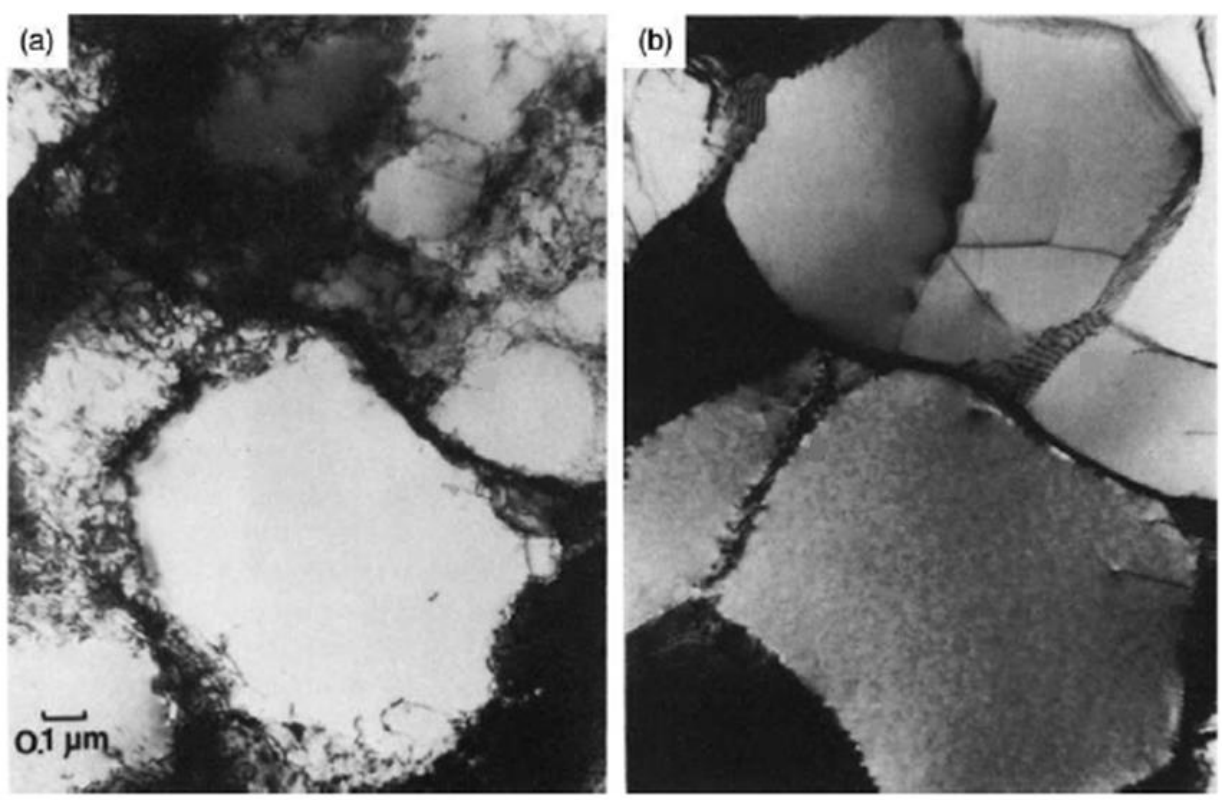

Figura 23 - Micrografias obtidas via microscopia eletrônica de transmissão de amostras de alumínio de alta pureza após deformação (à esquerda) e após recozimento a $250^{\circ} \mathrm{C}$ por 2 minutos (à direita) [73]

\subsubsection{Cinética de recuperação}

O presente trabalho apresentará dois modelos usualmente adotados para estudar a cinética de recuperação dos materiais metálicos. O primeiro, discutido brevemente e apresentado por Humphreys e Harthely [73], obedece a equação geral:

$$
\frac{1}{\rho}=\frac{1}{\rho_{0}}+k t
$$

Onde $\rho$ é a densidade de linhas de discordância em um dado instante de tempo $t$, $\rho_{0}$ é a densidade inicial de linhas de discordância e $\mathrm{k}$ é uma constante a ser determinada. A Figura 24 mostra de maneira esquemática a representação gráfica da cinética de recuperação. 


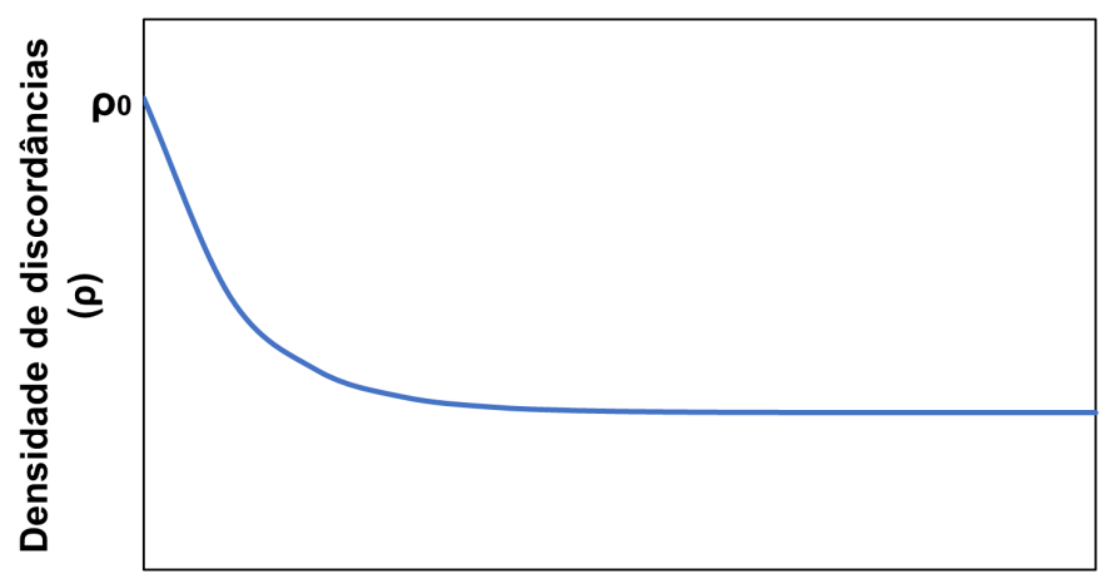

Tempo de recozimento $(t)$

Figura 24 - Curva esquemática da cinética de recuperação de um material metálico deformado e recozido a temperatura constante

Outro modelo consolidado para avaliar a cinética de recuperação foi deduzido por Kuhlmann [74] em 1948 - uma lei logarítmica para quantificar a porcentagem recuperada de um material recozido a uma dada temperatura:

$$
\% \text { Recuperada }=A-B \ln t
$$

Onde t é o tempo de recozimento e A e B são constantes a serem determinadas.

A cinética de recuperação de materiais metálicos pode (de maneira mais simples e estatisticamente mais confiável) ser quantificada através de medidas indiretas. Dessa forma, ao invés de se medir a densidade de discordâncias antes e após o recozimento via microscopia eletrônica de transmissão (o que, além de um trabalho exaustivo, significaria analisar uma área muito reduzida e frequentemente pouco representativa), usa-se medidas de dureza, limite de escoamento, ou limite de resistência à tração e atribui-se que a variação dessas propriedades esteja diretamente associada à densidade de discordâncias.

\subsection{Recristalização}

A recristalização é o fenômeno de formação e crescimento de novos grãos, em meio a uma matriz metálica encruada, que ocorre durante o recozimento do material deformado [71]. Um material recristalizado perde resistência mecânica (representada pela queda de dureza e limite de escoamento, por exemplo), mas tem algumas de suas propriedades, como tenacidade à fratura e ductilidade, restauradas. 
Em termos microestruturais, é possível entender a recristalização como a migração de contornos de alto ângulo que varrem uma matriz encruada de modo a eliminar os defeitos cristalinos da região varrida. Essa migração de contornos, e consequente redução do número de defeitos cristalinos, tem como força motriz a redução da energia interna armazenada em virtude da deformação plástica. Por questões didáticas, o fenômeno é em geral dividido em nucleação e crescimento, etapas que serão discutidas nos próximos tópicos.

\subsubsection{Nucleação da recristalização}

Por nucleação da recristalização, entendem-se os mecanismos de rearranjo de discordâncias de modo a formar uma região praticamente livre de defeitos cristalinos delimitada por um contorno de alto ângulo.

Embora consolidado, o termo nucleação, que será adotado no presente trabalho, não é estritamente adequado para descrever o início do fenômeno. Isso porque é altamente improvável que ocorra a formação de um núcleo de segunda fase em meio à matriz encruada em virtude de flutuações energéticas, como é o caso da solidificação ou da precipitação [75]. As teorias mais bem aceitas acreditam que os núcleos de recristalização já existem de maneira latente no estado deformado, isto é, antes mesmo do início do recozimento [76]. Três mecanismos propostos para descrever o início da recristalização são brevemente apresentados a seguir:

a) Migração de contornos de preexistentes: Esse mecanismo estabelece que a migração dos contornos de alto ângulo preexistentes acontece devido à diferença do grau de deformação entre duas regiões adjacentes. A ocorrência deste mecanismo é condicionada à redução da energia global do sistema. Em outras palavras, a redução da energia associada à eliminação de defeitos cristalinos deve compensar o aumento da energia relativa ao crescimento da superfície do contorno de grão em migração, conforme indica de maneira esquemática a Figura 25. A migração de contornos preexistentes é um mecanismo predominante para graus de deformação de até $40 \%$. 


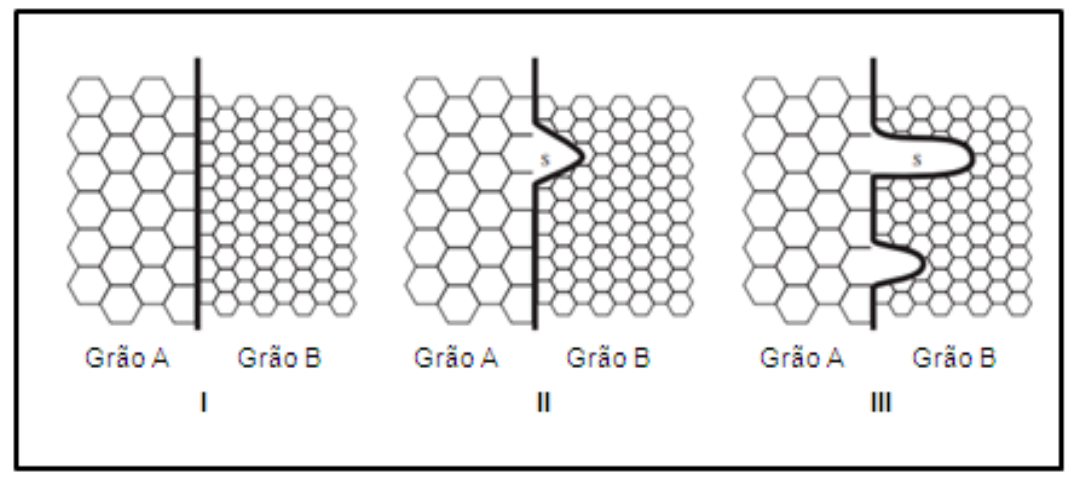

Figura 25 - Mecanismo de migração de contornos pré-existentes. O contorno migra do grão A, menos deformado, na direção do grão $\mathrm{B}$, mais deformado. As estruturas representadas dentro de cada grão são células de discordâncias

b) Nucleação pela migração de contornos de baixo ângulo: Proposto de maneira independente por Cahn [77] e Beck [78], o mecanismo propõe a formação de uma região com baixa concentração de defeitos circundada por contornos de baixo ângulo (subcontornos) capazes de migrar. Tal migração faz com que discordâncias sejam absorvidas pelos subcontornos e faz com que estes aumentem a diferença de orientação entre duas regiões adjacentes até se transformarem em contornos de alto ângulo também capazes de se movimentar e de varrer a microestrutura. A migração de subcontornos é, em geral, atuante para materiais de baixa EDE que sofreram elevada deformação e que são recozidos em temperaturas elevadas (maiores que 0,7 da temperatura absoluta de fusão). A Figura 26 ilustra esquematicamente 0 mecanismo.

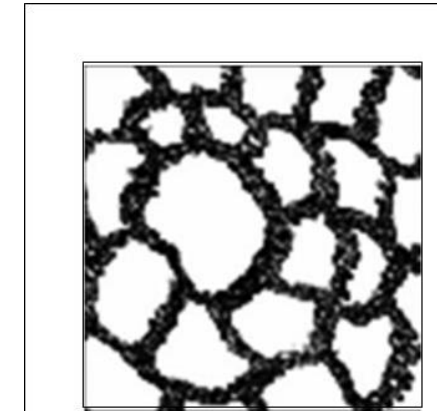

(A)

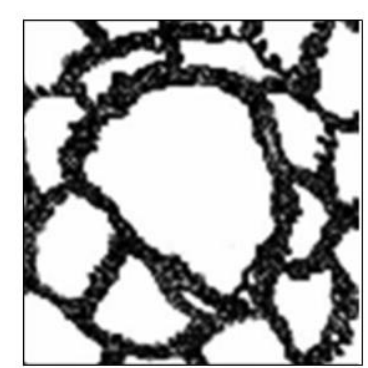

(B)

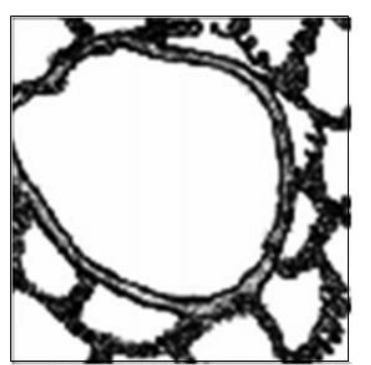

(C)

Figura 26 - Formação de um núcleo de recristalização a partir de um subgrão. (A) arranjo inicial, (B) O subgrão maior cresce às custas dos vizinhos, (C) Núcleo de recristalização é formado. [73]

c) Nucleação por coalescimento de subgrãos: O mecanismo propõe que um núcleo de recristalização seja gerado por meio do coalescimento de subgrãos vizinhos. De maneira equivalente, o fenômeno pode ser descrito como resultado da rotação de um subgrão em relação a outro, como esquematizado pela Figura 27.0 
mecanismo em questão é, aparentemente, atuante em temperaturas de recozimento mais baixas, e já foi observado e estudado em ligas de alumínio [79].

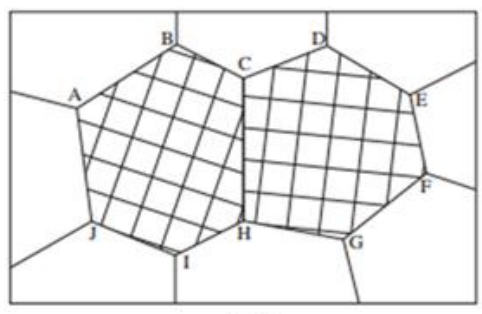

(a)

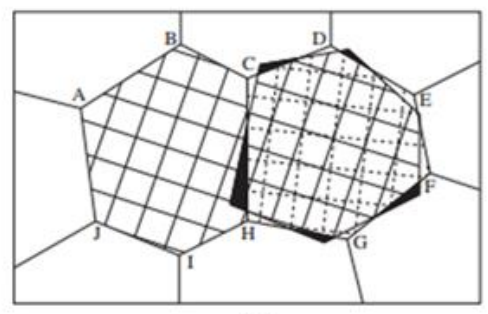

(b)

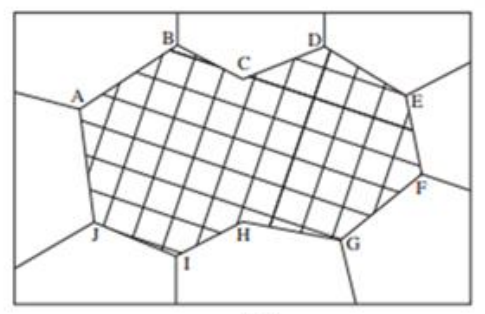

(c)

Figura 27 - Coalescimento de subgrãos. (a) Arranjo inicial antes da ocorrência do fenômeno, (b) Migração de subcontornos que causa efeito similar à rotação do subgrão CDEFGH. (c) Subgrão coalescido [80]

\subsubsection{Crescimento das regiões recristalizadas}

- A velocidade de migração dos contornos que varrem a microestrutura eliminando os defeitos cristalinos é descrita de acordo com:

$$
V=m \Delta P
$$

Onde $\mathrm{m}$ é a mobilidade dos contornos e $\mathrm{P}$ o potencial termodinâmico para a ocorrência da transformação. Na realidade, $\Delta \mathrm{P}$ representa a soma do potencial termodinâmico ou força motriz e das forças retardadoras ou de arraste.

Como colocado por Rollet e coautores [81], o modelo proposto pela equação anterior, embora útil pela sua simplicidade e clareza, não descreve de maneira precisa a migração dos contornos de grão. Além disso, o termo "m" associado à mobilidade dos contornos, não deixa explícito quais parâmetros exercem influência sobre a velocidade "V". Burke e Turnbull [82] propuseram um modelo modificado que expressava a velocidade de migração dos contornos como indicado por:

$$
V=\left[\frac{b^{4} f}{k T} \exp \left(\frac{-E_{A}}{k T}\right)\right] \Delta P
$$

Onde b é um parâmetro relacionado ao tamanho do átomo do material, $f$ é a freqüência atômica com que ocorrem saltos através da interface (nesse caso o contorno de grão), $E_{A}$ é a energia de ativação para a movimentação atômica, k é a constante de Boltzman e T é a temperatura do sistema estudado. 


\subsubsection{Cinética de recristalização}

Dos modelos matemáticos existentes para descrever a cinética de recristalização, o proposto pelos pesquisadores Johnson, Mehl, Kolmogorov e Avrami (JMAK) é um dos que mais se destaca pela sua simplicidade e boa correlação com os dados experimentais. De acordo com esse modelo, a fração recristalizada $(X)$ de um material deformado e recozido a uma dada temperatura pode ser estimada segundo:

$$
X=1-\exp \left(-A t^{n}\right)
$$

Onde A e n são constantes que podem ser determinadas experimentalmente e $t$ é o tempo de recozimento.

A correlação é em geral feita por meio do ajuste dos resultados experimentais (obtidos via estereologia quantitativa ou via medidas indiretas, como a dureza) ao modelo JMAK na forma linearizada, isto é:

$$
\ln \left[\ln \frac{1}{(1-X)}\right]=\ln A+n \ln t
$$

A Figura 28 mostra algumas curvas JMAK que representam a cinética de recristalização do alumínio de elevada pureza deformado $40 \%$ por laminação e recozido em diferentes temperaturas. É possível notar que para temperaturas mais baixas, os dados experimentais começam a sofrer desvios em relação ao modelo matemático. Tais faixas de temperatura favorecem a ocorrência o fenômeno de recuperação, que diminui o potencial termodinâmico para a ocorrência da recristalização. 


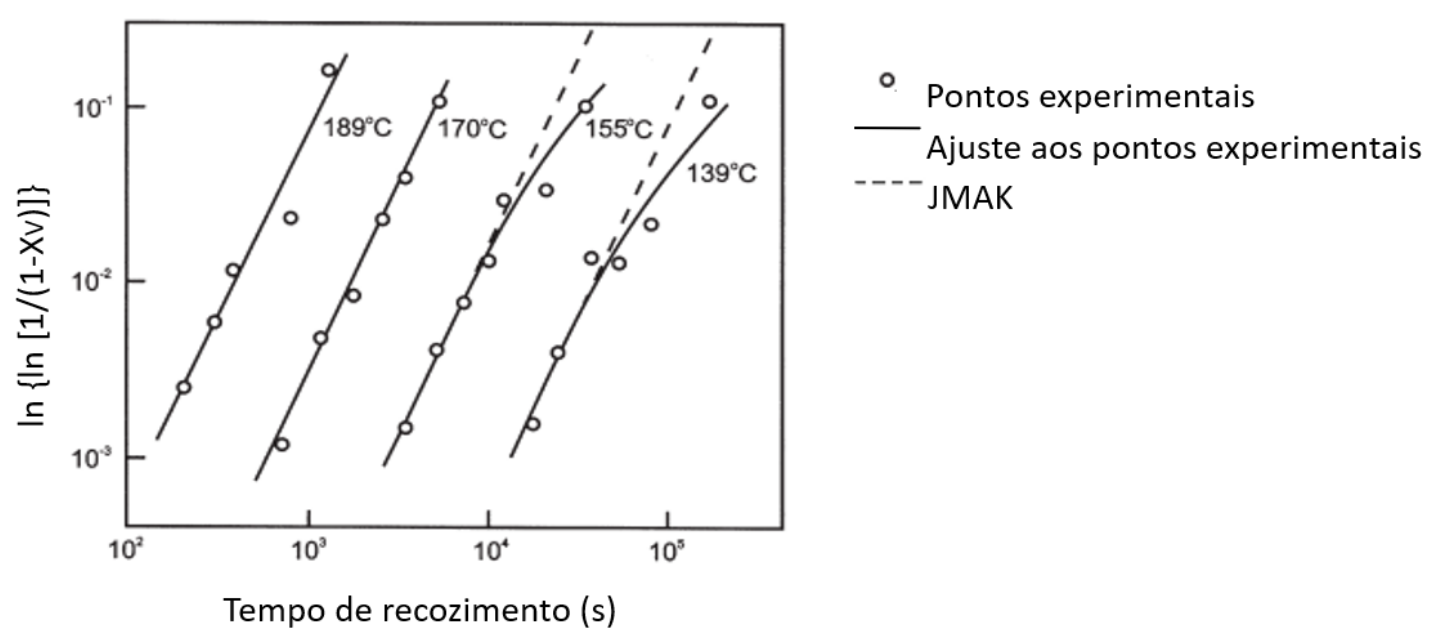

Figura 28 - Curvas baseadas no modelo JMAK para alumínio de elevada pureza deformado 40\% por laminação e recozido em diferentes temperaturas [83]

O modelo JMAK considera algumas hipóteses simplificadoras, sendo elas:

- A taxa de nucleação de novos grãos é constante;

- A taxa com a qual novos grãos crescem obedece a uma lei linear;

- A nucleação ocorre deforma aleatória e homogênea.

Sabe-se, por exemplo, que a nucleação de novos grãos se dá em locais de maior energia (regiões com alta concentração de defeitos e heterogeneidades) e não de maneira aleatória e homogênea, como adotado pelo modelo JMAK. Dessa forma, a adoção de tais hipóteses pode levar o modelo a se desviar dos resultados experimentais. Não obstante, a relação proposta por Johnson, Mehl, Kolmogorov e Avrami ainda é constantemente utilizada em estudos envolvendo a cinética de recristalização das ligas de alumínio [84], [85], [86].

\subsubsection{Influência da presença de partículas de segunda fase e de átomos de soluto na cinética de recristalização}

A adição de átomos de soluto, ou a formação de precipitados de segunda fase em meio a matriz, tende a alterar a cinética de recristalização de um material metálico. A Figura 29 mostra que a presença de pequenos teores de ferro em solução sólida retarda a migração dos contornos de grão - embora a presença de átomos de soluto cause um aumento na energia interna armazenada em um material deformado, as 
forças de arraste que as nuvens desses átomos impõem sobre os contornos de grão em migração atrasam a recristalização.

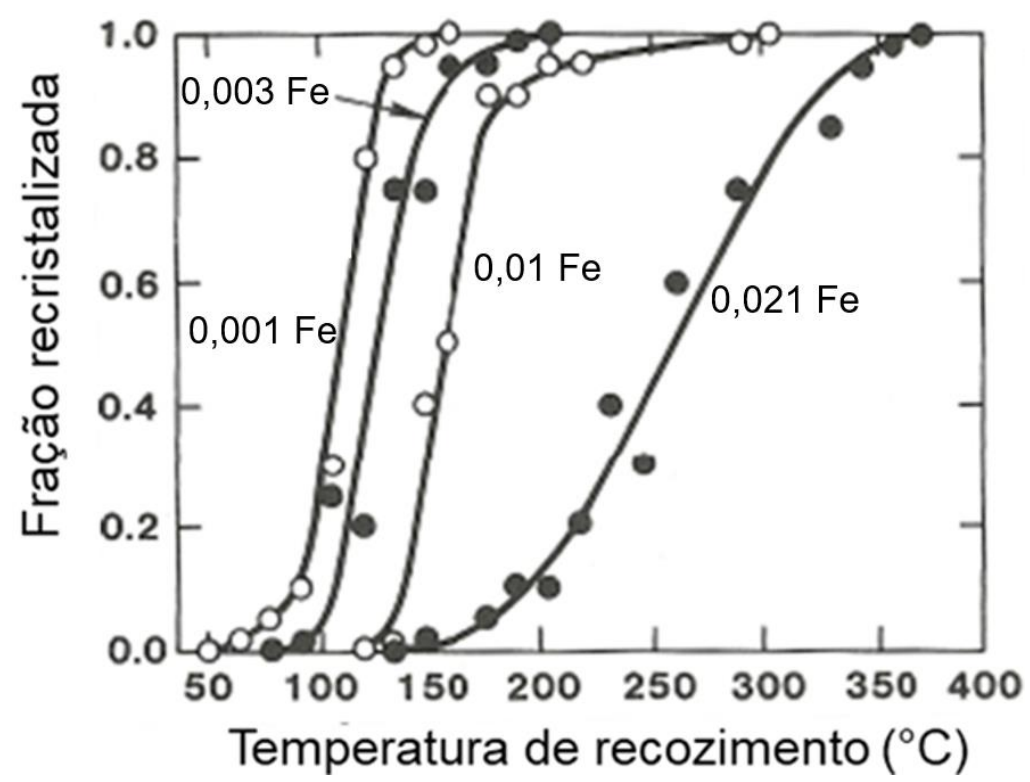

Figura 29- Efeito de teores de Fe em solução sólida na cinética de recristalização do Al de alta pureza (1XXX) [87]

A presença de partículas de segunda fase pode causar tanto retardo como aumento da velocidade de recristalização. O fator que determina a ocorrência de um comportamento ou de outro é, fundamentalmente, o tamanho das partículas de segunda fase. Um material contendo partículas grosseiras (diâmetro maior que $1 \mu \mathrm{m}$ ) tende, quando deformado, a reter uma maior densidade de discordâncias ao redor dessas partículas, já que a acomodação da deformação acontece somente na matriz. Nessas regiões, são formados novos "núcleos" (isso é, regiões de baixa concentração de defeitos delimitadas por contornos de grão de alto ângulo) em um fenômeno denominado PSN - particle stimulated nucleation. A Figura 30 ilustra esquematicamente a deformação da rede ao redor de uma partícula grosseira. A Figura 31 mostra a formação dessa zona ao redor de uma partícula constituinte para a liga AA 3103 deformada a frio. 


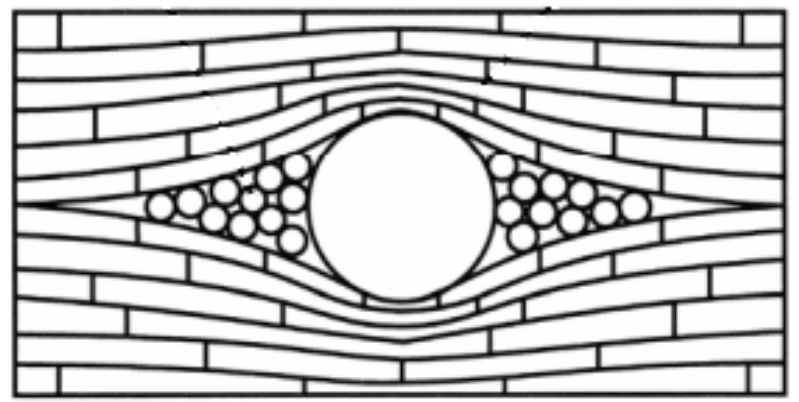

Figura 30 - Estrutura esquemática representando a distorção na rede gerada ao redor de partículas intermetálicas grosseiras [88]

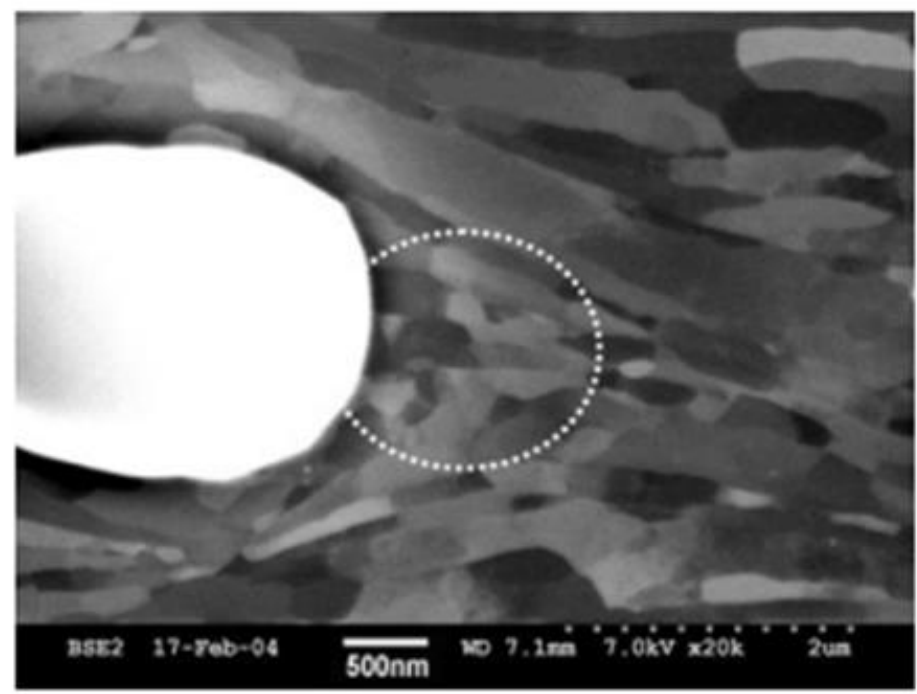

Figura 31 - Micrografia obtida com auxílio de microscopia eletrônica de varredura (modo elétrons retroespalhados) evidenciando a recristalização ao redor de partícula de fase intermetálica para a liga AA 3003 deformada a frio. [89]

Por outro lado, partículas finas (diâmetro menor que $1 \mu \mathrm{m}$ ) e pouco espaçadas tendem a gerar a) uma estrutura de discordâncias mais homogeneamente distribuídas e b) o ancoramento dos subcontornos e contornos de grão em migração [90]. Ambos os efeitos contribuem para retardar a cinética de recristalização.

Para o caso do recozimento de soluções sólidas supersatutadas, existem faixas de temperatura em que os fenômenos de recristalização e precipitação podem se sobrepor e se influenciar. A Figura 32 mostra curvas TTT esquemáticas para ligas de alumínio deformadas por laminação e posteriormente recozidas. Para temperaturas de recozimento maiores que $T_{1}$ apenas a recristalização acontece. Para temperaturas de recozimento entre $T_{1}$ e $T_{2}$ a recristalização se completa antes do início da precipitação. Para temperaturas inferiores a $T_{2}$ a precipitação acontece antes do início 
da recristalização, o que tem influência sobre a migração dos contornos de alto ângulo e, por consequência, atrasa a cinética de formação dos novos grãos.

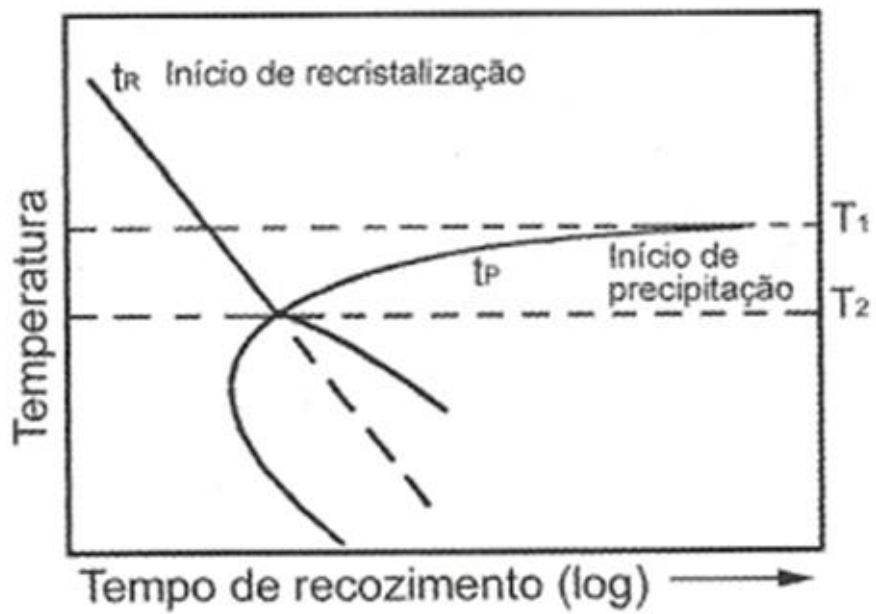

Figura 32 - - Curvas TTT esquemáticas para recristalização e precipitação em ligas de alumínio. Adaptado de [91]

Em relação ao recozimento de soluções sólidas supersaturadas, Jones e Humphreys [92] mostraram que o recozimento de ligas do sistema Al-Sc em determinadas temperaturas resulta em uma microestrutura com diferentes faixas de tamanho de grão. A explicação dada ao fenômeno é relacionada à redução da velocidade da recristalização após o início da precipitação das partículas de segunda fase. Dessa forma, grãos que surgiram antes da precipitação já estão na etapa de crescimento (resultando em grãos maiores) enquanto outros, que são nucleados após início da precipitação, enfrentam a dificuldade de crescimento em função da presença dos pequenos precipitados. A Figura 33 mostra uma micrografia para a liga Al -0,12\% Sc recozida por um minuto a $425^{\circ} \mathrm{C}$.

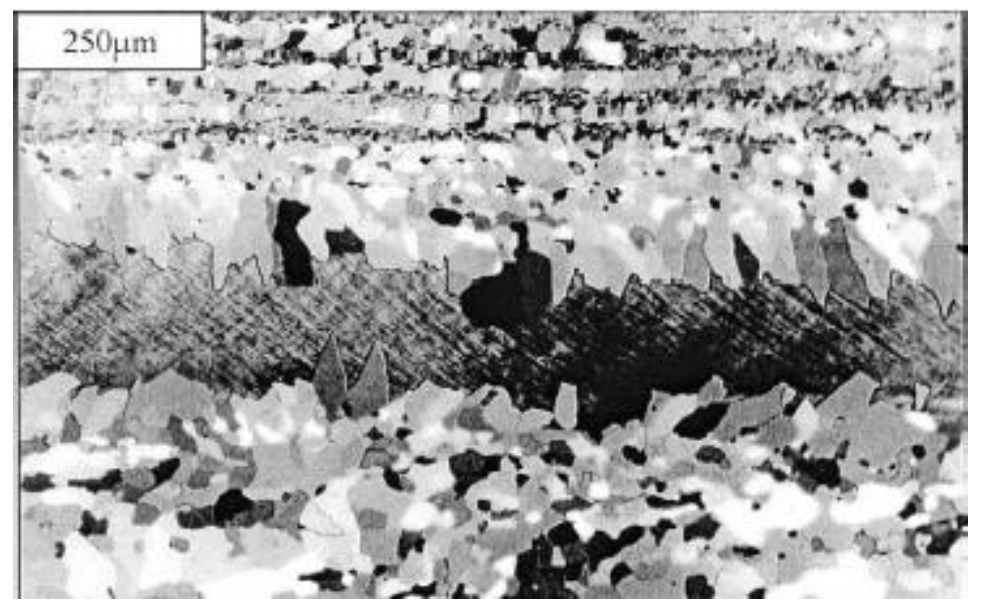

Figura 33- Micrografia obtida por microscopia eletrônica de varredura (no modo elétrons retroespalhados) da Al $0,12 \%$ p Sc deformada e recozida por um minuto a $425^{\circ} \mathrm{C}$ [92] 


\subsubsection{Recristalização dinâmica}

Em termos práticos, a recristalização dinâmica pode ser compreendida como o processo de recristalização que ocorre durante a deformação plástica do material metálico, ou seja, o material está submetido à tensão e temperatura simultaneamente aplicadas. A mesma ideia pode ser pode ser estendida ao processo de recuperação e à chamada recuperação dinâmica. Os fenômenos de recuperação dinâmica tem notória importância na explicação de fenômenos como a superplasticidade de algumas ligas de alumínio [93]. Já o conceito de recristalização dinâmica também é aplicado na produção de ligas de alumínio de grãos ultrafinos (da ordem de $100 \mathrm{~nm}$ ), materials altamente tecnológicos e de aplicação estrutural [94].

Fundamentalmente, existem três fatores que influenciam a ocorrência de recristalização dinâmica em um dado material: O grau de deformação imposto, a temperatura de deformação e a energia de falha de empilhamento (EFE). De maneira resumida, baixa EFE e elevadas temperaturas e graus de redução tendem a promover a ocorrência do fenômeno. Sendo o alumínio um material de elevada EFE, conclui-se que a ocorrência de recristalização dinâmica desse material necessita de elevado grau de deformação e de elevada temperatura de deformação. A Figura 34 ilustra, de maneira esquemática, a ocorrência dos fenômenos dinâmicos para algumas situações de graus de deformação e materiais de diferentes EFE.

a)

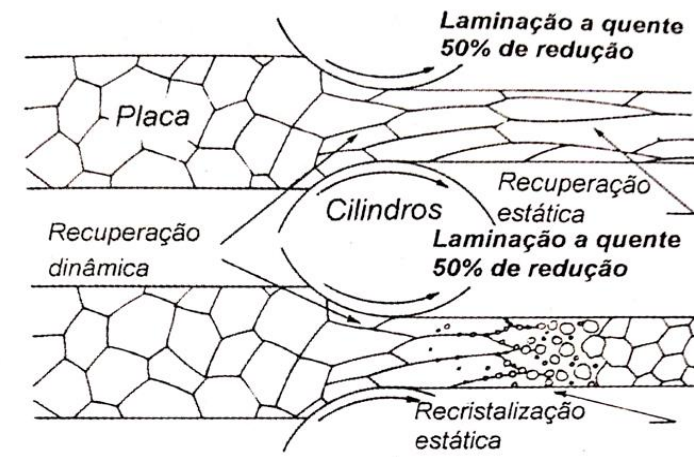

c)

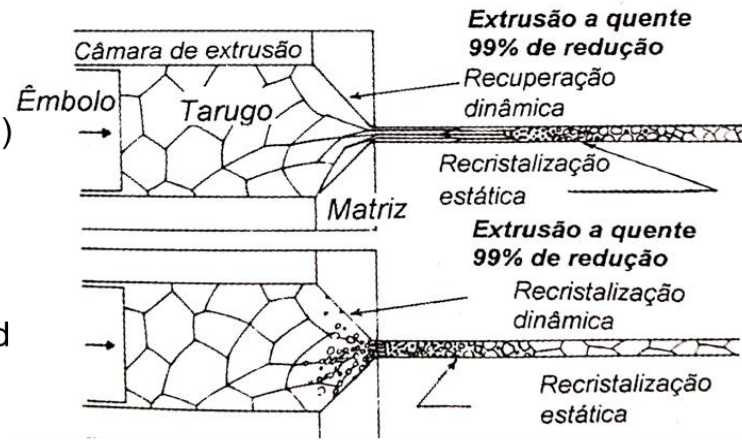

Figura 34 - a) Ocorrência de recuperação estática em materiais de alta EDE submetidos à laminação a quente (baixo grau de deformação). b) Em materiais de baixa EDE é possível que haja, além da recuperação dinâmica, recristalização após deformação a quente. C) elevados graus de deformação (como a extrusão) e altas temperaturas de deformação aplicados em materiais de alta EDE tendem a promover a recuperação dinâmica e a recristalização após deformação (estática). d) Já aplicando as mesmas condições do item anterior à materiais de baixa EDE, tende-se à obter uma estrutura de grãos recristalizados de maneira dinâmica - Adaptado de [95] 


\subsection{Crescimento de grão}

Uma vez terminado o processo de crescimento das regiões recristalizadas, temse uma microestrutura de grãos refinados e que possui concentração de defeitos cristalinos ordens de grandeza menor em relação ao estado encruado. O processo de recristalização é, dessa forma, acompanhado da redução da energia interna do material. Observa-se, no entanto, que a microestrutura resultante não é (em termos termodinâmicos) a mais estável possível. Isso porque grãos mais finos implicam em maior área de contornos de grão, que por sua vez levam a um aumento da energia interna associada às numerosas interfaces. Dessa forma, após o término da recristalização, e com o objetivo de atingir um estado mais estável, o recozimento subsequente faz com que os grãos comecem a crescer de modo a reduzir a área total dos contornos. A Figura 35 ilustra de maneira esquemática o fenômeno do crescimento de grão.
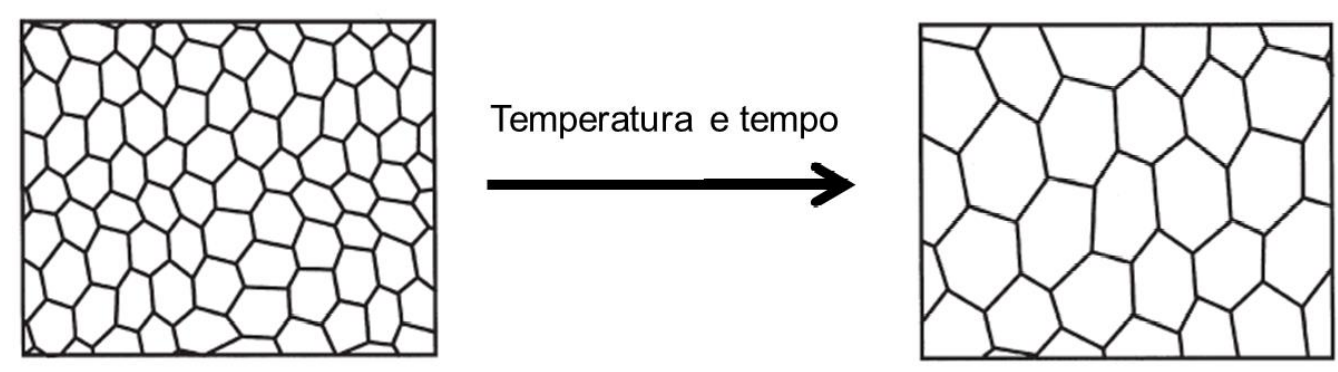

Figura 35 - Representação esquemática do fenômeno de crescimento de grão [73]

A velocidade de migração dos contornos durante o crescimento de grão depende fortemente de fatores como temperatura, presença de átomos em solução sólida e de precipitados de segunda fase. Enquanto a mobilidade dos contornos aumenta com o aumento da temperatura (já que o fenômeno é termicamente ativado), ela diminui com a presença de precipitados e/ou átomos que tendem a ancorar o movimento dos contornos.

Embora ambos, recristalização e crescimento de grão, envolvam a migração de contornos de alto ângulo, existem algumas diferenças entre os dois casos:

1) O potencial termodinâmico para ocorrência do crescimento de grão é a diminuição da área total dos contornos. No caso da recristalização, é a energia acumulada na forma de defeitos cristalinos que assume esse papel. 
2) A velocidade de migração dos contornos durante a recristalização é, em geral, mais elevada quando comparada à velocidade de migração durante o crescimento de grão.

3) Durante o crescimento de grão, os contornos se movem no sentido do seu centro de curvatura. Já na recristalização, o movimento dos contornos se dá no sentido contrário ao da curvatura.

\subsubsection{Cinética de crescimento de grão}

A seguir, serão apresentados alguns modelos matemáticos comumente utilizados em estudos de cinética de crescimento de grão.

Em 1952, Burke e Turnbull [96] deduziram uma expressão para descrever a cinética de crescimento de grão assumindo que uma força motriz $(P)$ atua no sentido de promover a migração dos contornos de acordo com:

$$
P=\frac{\alpha \gamma}{D}
$$

Onde $\gamma$ é a energia por unidade de área associada aos contornos, D é o diâmetro médio dos grãos e $\alpha$ é uma constante relacionada à geometria dos grãos. O modelo em questão assume que a velocidade de migração dos contornos é proporcional à força motriz P, isto é:

$$
\frac{d D}{d t}=c_{1} P=c_{1} \frac{\alpha \gamma}{D}
$$

Onde $c_{1}$ é uma constante de proporcionalidade. Integrando de $D_{0}$ (diâmetro inicial) até um $\mathrm{D}(\mathrm{t})$ :

$$
\int_{D_{0}}^{D} D . d D=\int_{0}^{t} c_{1} \alpha \gamma d t \rightarrow D^{2}-D_{0}^{2}=2 c_{1} \alpha \gamma t
$$

Fazendo $2 \alpha \gamma c_{1}=k$, obtem-se:

$$
D^{2}-D_{0}^{2}=k t
$$

Huda e Zaharinie [97] propuseram uma forma modificada da relação parabólica expressa anteriormente, de acordo com: 


$$
D-D_{0}=k t^{n}
$$

Onde a constante $n$ é denominada expoente de crescimento de grão. A Tabela 5 exibe um compilado de valores de $n$ para metais de alta pureza apresentado por Humphreys e Hatherly [73]. Em função dos mecanismos de ancoramento de contornos por precipitados e átomos de solução sólida, sabese que as ligas metálicas possuem, em geral, valores de $n$ menores do que os respectivos metais de elevada pureza.

\begin{tabular}{l} 
Tabela $\mathbf{5}$ - Valores de $\mathrm{n}$ (expoente de crescimento de grão) para diferentes metais de alta pureza [73] \\
\cline { 2 - 2 } \\
\begin{tabular}{cc} 
Metal & $\mathbf{n}$ \\
\hline $\mathrm{Al}$ & 0,25 \\
$\mathrm{Fe}$ & 0,40 \\
$\mathrm{~Pb}$ & 0,42 \\
$\mathrm{Sn}$ & 0,43 \\
\hline
\end{tabular}
\end{tabular}

Já de acordo com Beck [98], a equação anterior pode ser expressa de maneira modificada (e genérica) de acordo com:

$$
D^{1 / n}-D_{0}^{\frac{1}{n}}=G t
$$

A constante $\mathrm{G}$, que representa a taxa de crescimento de grãos, é função da temperatura segundo:

$$
G=G_{o} \exp \left(\frac{-Q}{R T}\right)
$$

Onde $G_{0}$ é uma constante a ser determinada, $R$ é a constante universal dos gases, T é a temperatura e $Q$ é a energia de ativação para o crescimento de grão.

\subsection{PCGZ - Zona de grãos periféricos grosseiros}

O crescimento (exagerado) dos grãos periféricos é um defeito comum às ligas extrudadas de alumínio, seja na forma de barras quadradas, circulares ou tubos 
vazados. A Figura 36 mostra a ocorrência do fenômeno em tubo extrudado da AA 6005.

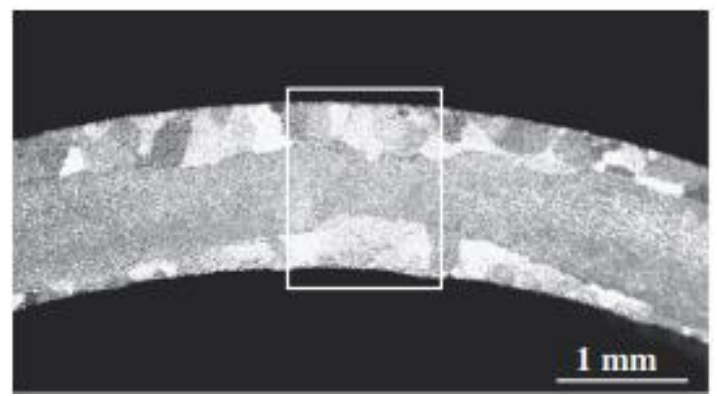

Figura 36 - Macrografia de tubo extrudado da AA 6005. Nota-se a presença da zona de grãos grosseiros nas regiões periféricas [99]

A formação dessa estrutura de grãos possui grande influência (em geral deletéria) sobre as propriedades mecânicas dos materiais. Sabe-se, por exemplo, que - PCGZ reduz de maneira significativa a usinabilidade de barras de alumínio extrudadas [100]. Dessa maneira, a busca pelo entendimento dos mecanismos que regem a formação dessa estrutura, bem como a influência de cada parâmetro de processamento sobre o surgimento deste defeito, se torna de vital importância para produzir materiais com propriedades desejadas.

De maneira simplificada, a formação de tal microestrutura parece estar ligada à combinação de três fatores: elevadas temperaturas, elevadas taxas de deformação e elevadas deformações. Eivani e colaboradores [101] propuseram um mecanismo para descrever a ocorrência tal fenômeno na liga Al-4.5Zn-1Mg extrudada. A teoria, baseada nas observações realizadas pelos autores via microscopia óptica de luz polarizada e EBSD, é sumariamente descrita a seguir:

1) No início do processo deformação a quente ocorre a recuperação dinâmica e a consequente formação de subgrãos. Nesse estágio inicial não é esperada a ocorrência de recristalização estática ou dinâmica em função da elevada energia de defeito de empilhamento (EDE) do alumínio e suas ligas e da ocorrência anterior de recuperação.

2) Com a continuidade do processo de deformação mecanismos como a nucleação estimulada por partículas (PSN), somado às altas taxas de deformação na periferia do material extrudado resultam na nucleação de alguns grãos de maneira dinâmica. Esses novos grãos possuem pequena diferença de orientação em relação 
à matriz encruada. Em termos práticos, isso significa que o crescimento das regiões recristalizadas dinamicamente será mais lento em relação aos grãos recristalizados de maneira estática.

3) Após o processo de deformação, acontece a recristalização estática durante o recozimento, ou recristalização metadinâmica caso a temperatura do material seja mantida elevada após a saída da extrusora. Os grãos recristalizados dessa maneira crescem mais rapidamente em relação aos que se formaram por recristalização dinâmica. Dessa forma, a zona de grãos grosseiros tem origem no crescimento anormal dos grãos recristalizados de maneira estática.

O mecanismo descrito é representado esquematicamente na Figura 37.

(a)

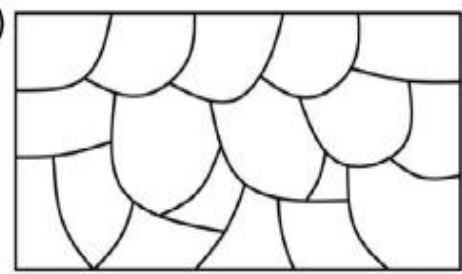

(c)

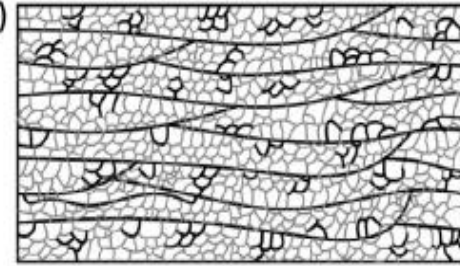

(e)

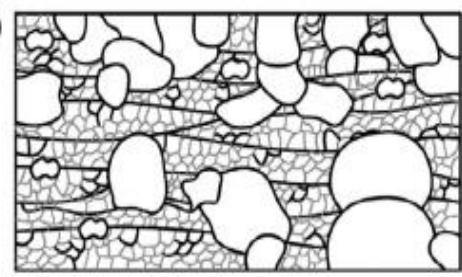

(b)

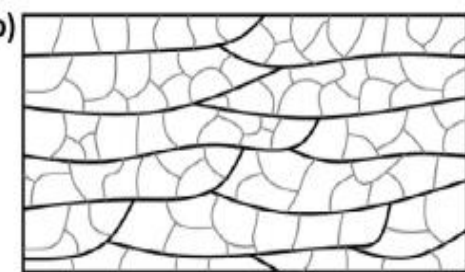

(d)

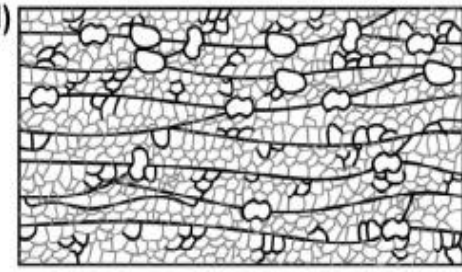

(f)

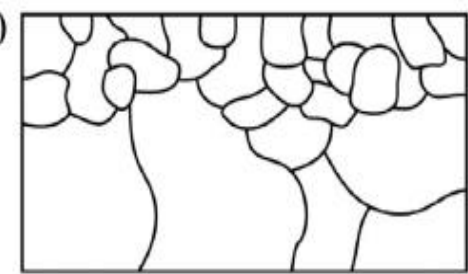

Figura 37 - Representação esquemática do mecanismo de formação do PCG proposto por Eivani. (a) A microestrutura inicial possui grãos aproximadamente equiaxiais. (b) A ocorrência da deformação plástica leva à formação de subgrãos. (c) Os subgrãos formados diminuem de tamanho com a continuidade da deformação. Ao mesmo tempo ocorre a formação de uma estrutura parcialmente recristalizada (de maneira dinâmica). (d) Ao fim do processo de deformação, ocorre a nucleação e o crescimento de novos grãos de maneira estática. (e-f) Os grãos recristalizados de maneira estática crescem mais rapidamente do que os que foram recristalizados de maneira dinâmica, dando origem a microestrutura de grãos grosseiros periféricos

A Tabela 6 mostra uma compilação de diversos estudos envolvendo a extrusão do alumínio e suas ligas. Embora tais estudos possuam poucas semelhanças em relação aos parâmetros de processamento adotados, eles parecem convergir para 
alguns pontos em comum: A formação da PCGZ parece depender fortemente da velocidade de deformação $(\dot{\varepsilon})$, da razão de extrusão $(R)$ e da temperatura de deformação. Além disso, o fenômeno também é influenciado, em menor grau, pela composição química da liga utilizada. 
Tabela 6 - Compilado de resultados de estudos relacionados à extrusão do alumínio e suas ligas

\begin{tabular}{|c|c|c|c|c|c|c|c|c|}
\hline Liga & Composição & $\begin{array}{l}\text { Variáveis do } \\
\text { processo }\end{array}$ & $\begin{array}{l}\text { Ocorre formação } \\
\text { de PCGZ? }\end{array}$ & $\begin{array}{c}\text { Espessura } \\
\text { média } \\
\text { aproximada da } \\
\text { PCGZ }(\mu \mathrm{m}) \\
\end{array}$ & $\begin{array}{l}\text { Tamanho de } \\
\text { grão médio } \\
\text { aproximado da } \\
\text { PCGZ }(\mu \mathrm{m}) \\
\end{array}$ & $\begin{array}{l}\text { Textura da } \\
\text { PCGZ }\end{array}$ & Obs & Referência \\
\hline AA 6005 & $\begin{array}{l}0,4 \% \mathrm{Si}-0,2 \% \mathrm{Fe}- \\
0,15 \% \mathrm{Cu}-0,8 \% \mathrm{Mg}- \\
0,02 \% \mathrm{Ti}\end{array}$ & $\begin{array}{l}\text { Exrusão direta }-\mathrm{R}= \\
44 ; \mathrm{v}=50 \mathrm{~mm} / \mathrm{s} ; \mathrm{T}= \\
500^{\circ} \mathrm{C}, 520^{\circ} \mathrm{C} \mathrm{e} \\
580^{\circ} \mathrm{C}\end{array}$ & Não & - & - & - & $\begin{array}{l}\text { O atrito parece } \\
\text { estar relacionado } \\
\text { com a diferença } \\
\text { de textura } \\
\text { desenvolvida } \\
\text { entre a parede e } \\
\text { o interior do } \\
\text { material } \\
\text { extrudado }\end{array}$ & [102] \\
\hline AA 6061 & $\begin{array}{l}\text { Os autores apenas } \\
\text { colocam que a } \\
\text { composição estava de } \\
\text { acordo com o colocado } \\
\text { pela Aluminum } \\
\text { Association. Foram } \\
\text { usadas amostras com } \\
0,17 \% \text { e } 0,35 \% \text { em peso } \\
\text { de } \mathrm{Cr}\end{array}$ & $\begin{array}{l}\text { Extrusão indireta }-\mathrm{R} \\
=20 \text { e } \mathrm{R}=40 ; \mathrm{v}=1,3 \\
\text { e } 2,6 \mathrm{~mm} / \mathrm{s} ; \mathrm{T}= \\
400^{\circ} \mathrm{C} \text { e } 482^{\circ} \mathrm{C}\end{array}$ & Sim & $\begin{array}{l}\text { Variou de } 2,5 \% \\
\text { a } 27,5 \% \text { da } \\
\text { dimensão do } \\
\text { raio do cilindro } \\
\text { extrudado, } \\
\text { dependendo } \\
\text { das condições } \\
\text { de } \\
\text { processamento } \\
\text { e recozimento } \\
\text { adotadas. }\end{array}$ & - & $\begin{array}{l}\text { Os autores } \\
\text { estudaram } \\
\text { apenas a } \\
\text { textura de } \\
\text { amostras que } \\
\text { não formaram } \\
\text { PCGZ }\end{array}$ & $\begin{array}{l}\text { A espessura da } \\
\text { PCGZ varia com } \\
\text { a razão e a } \\
\text { velocidade de } \\
\text { extrusão. Quanto } \\
\text { maiores forem } \\
\text { tais parâmetros, } \\
\text { maior a } \\
\text { espessura da } \\
\text { camada de grãos } \\
\text { grosseiros. }\end{array}$ & [100] \\
\hline $\begin{array}{l}\mathrm{Al}-4.5 \mathrm{Zn}- \\
\quad 1 \mathrm{Mg}\end{array}$ & $\begin{array}{l}\text { Al-0.29Si-0.31Fe- } \\
0.2 \mathrm{Cu}-0.36 \mathrm{Mn}-1.22 \mathrm{Mg}- \\
4.37 \mathrm{Zn}-0.001 \mathrm{Ti}-0.10 \mathrm{Cr} \\
-0.20 \mathrm{Zr}\end{array}$ & $\begin{array}{l}\text { Extrusão direta; } v= \\
5 \mathrm{~mm} / \mathrm{s} ; \mathrm{T}=460^{\circ} \mathrm{C} \\
500^{\circ} \mathrm{C} \text { e } 540^{\circ} \mathrm{C} ; \mathrm{R}=16\end{array}$ & $\begin{array}{l}\text { Ocorreu para as } \\
\text { temperaturas de } \\
\text { extrusão de } 500 \text { e } \\
540^{\circ} \mathrm{C} \text {. A barra } \\
\text { extrudada a } 400^{\circ} \mathrm{C} \\
\text { só apresentou } \\
\text { PCGZ após } \\
\text { recozimento } \\
\text { posterior }\end{array}$ & 200 & 200 & $\begin{array}{l}\text { Não foi } \\
\text { estudado } \\
\text { pelos autores }\end{array}$ & - & [101] \\
\hline
\end{tabular}




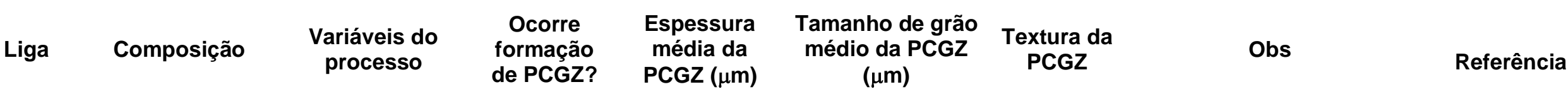

\begin{tabular}{|c|c|c|c|c|c|c|c|}
\hline AA 6063 & $\begin{array}{l}\mathrm{Al}-0,001 \mathrm{Cu}- \\
0,182 \mathrm{Fe}-0,025 \\
\mathrm{Mn}-0,011 \mathrm{Zn}- \\
0,567 \mathrm{Mg}-0,529 \\
\text { Si- 0,001 Cr- } \\
0,019 \mathrm{Ti}\end{array}$ & $\begin{array}{l}\text { Extrusão direta; } \\
\mathrm{v}=2,25 \mathrm{~mm} / \mathrm{s} ; \mathrm{R} \\
=11, \mathrm{~T}=460^{\circ} \mathrm{C} . \\
\text { Foram utilizados } \\
\text { diferentes ângulos } \\
\text { da matriz }\left(94^{\circ},\right. \\
\left.98^{\circ}, 102^{\circ} \text { e } 106^{\circ}\right)\end{array}$ & Sim & $\begin{array}{l}\text { Variando entre } \\
\text { aproximadame } \\
\text { nte } 1900 \text { e } \\
4200, \\
\text { dependendo do } \\
\text { ângulo da } \\
\text { matriz }\end{array}$ & 500 & $\begin{array}{l}\text { Não foi } \\
\text { estudado } \\
\text { pelos } \\
\text { autores }\end{array}$ & $\begin{array}{l}\text { O valor de certos } \\
\text { ângulos de matriz (98 } \\
\text { para o estudo) induz } \\
\text { uma PCGZ com menor } \\
\text { espessura em relação } \\
\text { aos demais ângulos } \\
\text { adotados }\end{array}$ \\
\hline
\end{tabular}

A formação da PCGZ

Al- $0,2 \mathrm{Cu}-0,28$

Extrusão direta; v

matriz

parece estar associada

à elevação da

temperatura combinada

às elevadas taxas de

deformação impostas à

região periférica durante

$0,08 \mathrm{Zr}$

pelos autores

estudado

pelos

a extrusão.

Extrusão direta; $\mathrm{T}$

$430-470^{\circ} \mathrm{C}$, com

Foram utilizadas $\begin{array}{ll}430-470^{\circ} \mathrm{C} \text {, com } \\ \text { temperatura de }\end{array}$

duas ligas e a saída controlada

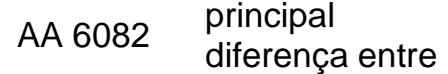

$\left(480^{\circ} \mathrm{C}\right.$ e $\left.520^{\circ} \mathrm{C}\right)$;

$=133 \mathrm{~mm} / \mathrm{s}$; os

elas era o teor de produtos

extrudados foram

forjados a $500^{\circ} \mathrm{C}$.

Variou entre

500 e 2500 ,

dependendo do

Sim

teor de cromo e

da temperatura

de saída do

extrudado
$500-1500$,

dependendo do

teor de $\mathrm{Cr}$ e da

temperatura de

saída do

extrudado
Não foi

estudado

pelos

autores
O teor de $\mathrm{Cr}$ e a

temperatura de extrusão

tendem a diminuir a

extensão da PCGZ nos

produtos de alumínio

extrudados 


\begin{tabular}{|c|c|c|c|c|c|c|c|c|}
\hline Liga & Composição & Variáveis do processo & $\begin{array}{c}\text { Ocorre } \\
\text { formação } \\
\text { de } \\
\text { PCGZ? }\end{array}$ & $\begin{array}{l}\text { Espessura média } \\
\text { da PCGZ }(\mu \mathrm{m})\end{array}$ & $\begin{array}{l}\text { Tamanho de } \\
\text { grão médio } \\
\text { da PCGZ } \\
(\mu \mathrm{m})\end{array}$ & $\begin{array}{c}\text { Textura } \\
\text { da PCGZ }\end{array}$ & Observações & Referência \\
\hline AA 6061 & $\begin{array}{l}\mathrm{Al}-0,62 \mathrm{Si}- \\
0,18 \mathrm{Fe}- \\
0,25 \mathrm{Cu}- \\
0,87 \mathrm{Mg}- \\
0,14 \mathrm{Mn}-0,1 \\
\mathrm{Cr}-0,02 \mathrm{Ti}\end{array}$ & $\begin{array}{l}\text { T variando entre } 360^{\circ} \mathrm{C} \text { e } \\
520^{\circ} \mathrm{C} ; \mathrm{R}=16 \text { e } 32 ; \mathrm{v}=16 \\
\mathrm{~mm} / \mathrm{s} \text { e } 40 \mathrm{~mm} / \mathrm{s}\end{array}$ & Sim & $\begin{array}{l}\text { Variou entre } 250 \text { e } \\
1000 \text { dependendo } \\
\text { dos parâmetros de } \\
\text { extrusão adotados }\end{array}$ & Não estimado & $\begin{array}{l}\text { Não } \\
\text { estudado } \\
\text { pelos } \\
\text { autores }\end{array}$ & $\begin{array}{l}\text { A presença e a } \\
\text { extensão da camada } \\
\text { de grãos grosseiros } \\
\text { dependem fortemente } \\
\text { da velocidade de } \\
\text { extrusão e da } \\
\text { temperatura de } \\
\text { extrusão }\end{array}$ & [106] \\
\hline AA 6082 & $\begin{array}{l}\mathrm{Al}-1,05 \mathrm{Si}- \\
0,18 \mathrm{Fe}- \\
0,60 \mathrm{Mg}- \\
0,50 \mathrm{Mn}- \\
0,03 \mathrm{Cr}-0,02 \\
\mathrm{Ti}\end{array}$ & $\begin{array}{l}\text { T variando entre } 360^{\circ} \mathrm{C} \text { e } \\
520^{\circ} \mathrm{C} ; \mathrm{R}=16 \text { e } 32 ; \mathrm{v}=16 \\
\mathrm{~mm} / \mathrm{s} \text { e } 40 \mathrm{~mm} / \mathrm{s}\end{array}$ & Sim & $\begin{array}{l}\text { Variou entre } 100 \text { e } \\
300 \text { dependendo } \\
\text { dos parâmetros de } \\
\text { extrusão adotados }\end{array}$ & Não estimado & $\begin{array}{l}\text { Não } \\
\text { estudado } \\
\text { pelos } \\
\text { autores }\end{array}$ & $\begin{array}{l}\text { A presença e a } \\
\text { extensão da camada } \\
\text { de grãos grosseiros } \\
\text { dependem fortemente } \\
\text { da velocidade de } \\
\text { extrusão e da } \\
\text { temperatura de } \\
\text { extrusão }\end{array}$ & [106] \\
\hline AA 6063 & $\begin{array}{l}\text { Al-1,05 Si - } \\
0,18 \mathrm{Fe}- \\
0,60 \mathrm{Mg}- \\
0,50 \mathrm{Mn}- \\
0,03 \mathrm{Cr}-0,02 \\
\mathrm{Ti}\end{array}$ & $\begin{array}{l}\text { Não especificado pelo autor, } \\
\text { que não variou os parâmetros } \\
\text { de extrusão e sim a } \\
\text { composição química das ligas } \\
\text { e o tempo de } \\
\text { homogeneização pós- } \\
\text { extrusão }\end{array}$ & Sim & $\begin{array}{l}\text { Variou entre } 15 \% \text { e } \\
50 \% \text { do raio do } \\
\text { produto extrudado, } \\
\text { dependendo da } \\
\text { composição química } \\
\text { e do tempo de } \\
\text { homogeneização }\end{array}$ & Não estimado & $\begin{array}{l}\text { Não } \\
\text { estudado } \\
\text { pelos } \\
\text { autores }\end{array}$ & $\begin{array}{l}\text { Maiores teores de } \\
\text { elemento de liga (Fe e Mn) } \\
\text { tendem a dificultar a } \\
\text { formação da PCGZ. } \\
\text { Menores tempos de } \\
\text { homogeneização tem } \\
\text { efeito análogo }\end{array}$ & [107] \\
\hline
\end{tabular}




\subsection{Textura cristalográfica nos materiais metálicos}

Os materiais metálicos de engenharia são constituídos por unidades denominadas grãos. Cada um desses grãos é formado por agrupamentos atômicos que possuem determinada orientação espacial e que se distinguem de seus vizinhos por fronteiras chamadas de contornos de grão. Os contornos de grão são, dessa forma, uma espécie de interface que separa dois grãos que possuem orientações cristalográficas distintas. Cabe ressaltar que outros defeitos, como os subcontornos, também separam regiões com orientações diferentes. No entanto, nesse caso, temse uma diferença de orientação menor em relação àquela associada ao contorno de grão de alto ângulo.

Caso a orientação dos grãos em uma dada amostra metálica não seja feita ao acaso, isto é, caso exista uma orientação preferencial em relação a um sistema de eixos coordenados (o que em geral e ocorre, uma vez que a orientação dos grãos é fortemente influenciada pelo processamento termomecânico a qual o material foi submetido [108]), diz-se que o material possui textura cristalográfica. A Figura 38 mostra de maneira esquemática uma chapa que possui textura.

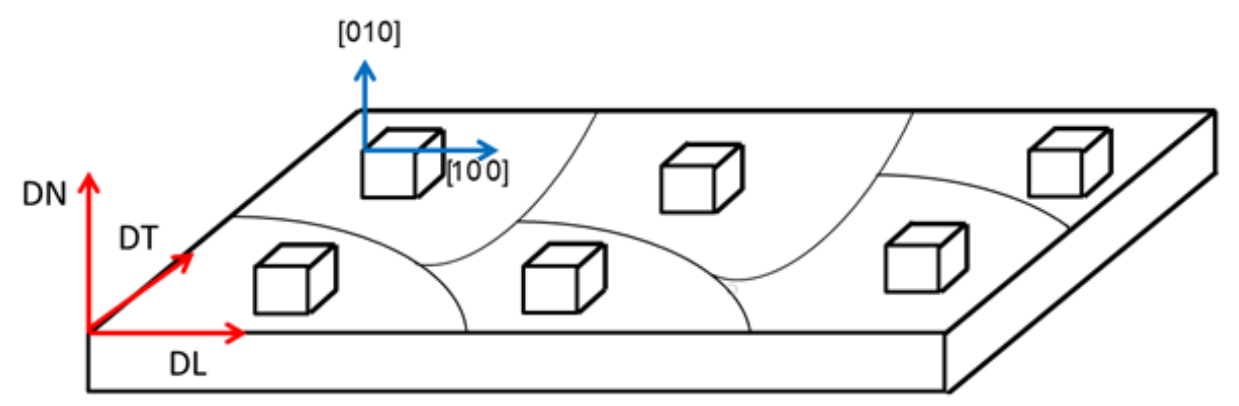

Figura 38 - Representação esquemática de chapa metálica com textura tipo cubo. DL, DN e DT representam as direções de laminação, normal e tranversal, respectivamente

A importância de estudar a textura dos diferentes materiais de engenharia reside no fato de que a orientação preferencial dos grãos resulta em respostas mecânicas distintas quando o mesmo material é submetido a esforços aplicados em direções diversas (a chamada anisotropia). Por exemplo, sabe-se que determinados componentes de textura favorecem os processos de embutimento e estiramento para produção de latas de alumínio. 


\subsubsection{Descrição das orientações e representação das texturas cristalográficas}

Um dos primeiros passos para compreensão e estudo da textura cristalográfica é o entendimento de como (matematicamente) são feitas as descrições e representações gráficas que caracterizam a orientação dos grãos que compõe um material. Os tópicos a seguir exploram as principais ferramentas utilizadas para essa finalidade.

\subsubsection{Sistemas de coordenadas - amostra e cristal}

Com o objetivo de estudar a textura cristalográfica dos materiais, é necessário estabelecer sistemas de referências que relacionem a orientação dos cristais com a amostra macroscópica.

Denomina-se sistema de coordenadas da amostra $A=\left\{a_{1}, a_{2}, a_{3}\right\}$ o referencial formado por eixos (preferencialmente) cartesianos estabelecidos de acordo com a geometria macroscópica. Analogamente, denomina-se sistema de coordenadas do cristal $\mathrm{C}=\{\mathrm{c} 1, \mathrm{c} 2, \mathrm{c} 3\}$ o sistema de eixos, também preferencialmente cartesianos, formado por direções específicas do cristal analisado. Considere uma chapa metálica laminada e suas respectivas direções de laminação (DL), normal (DN) e transversal (DT). Considere também, que um dado cristal que compõe o material possui uma orientação específica em relação à chapa. A situação previamente mencionada é representada na Figura 39.

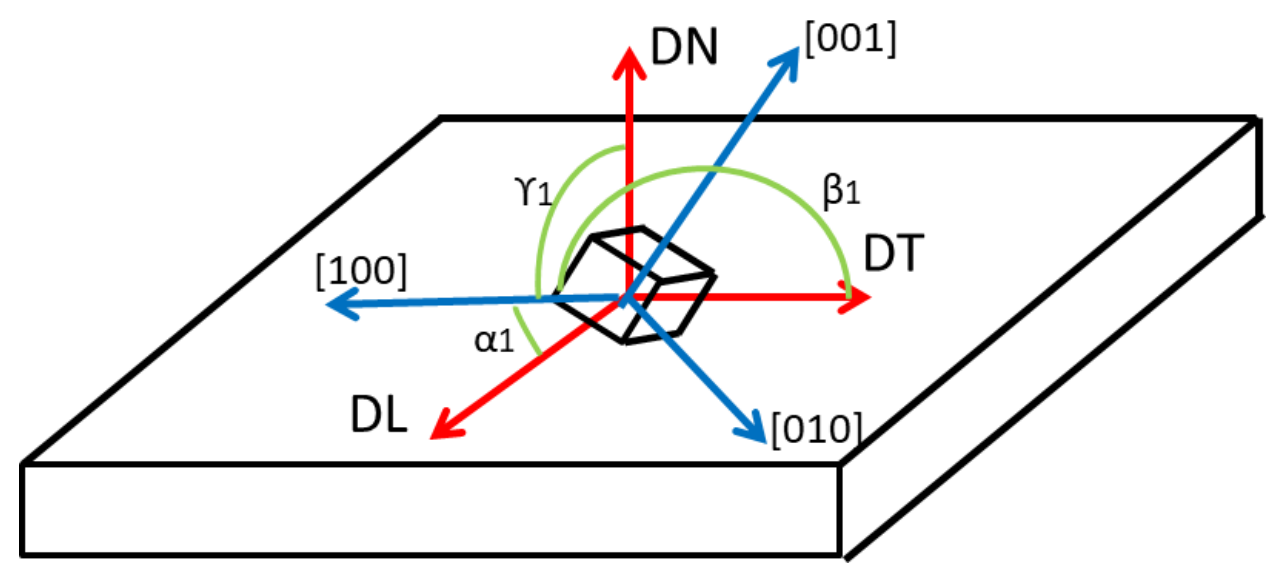

Figura 39 - Representação dos sistemas de coordenadas da amostra (A) e do cristal (C). Os ângulos $\alpha_{1}, \beta_{1}$ e $\gamma_{1}$ são respectivamente os ângulos entre a direção de laminação (DL) e as direções dos eixos do cristal 
Normalmente, adotam-se sistemas de coordenadas em função da geometria e do processamento mecânico ao qual foi submetido o material. Esses sistemas são escolhidos de modo a facilitar as análises posteriores. Assim, para amostras laminadas, é comum adotar $A=\{D L, D T, D N\}$. Da mesma forma, no que se refere ao cristal, o conjunto das direções mutualmente ortogonais $C=\{[100]$, [010] e [001]\} é geralmente adotado.

\subsubsection{A matriz de orientação}

Uma maneira de descrever a orientação de um cristal contido em uma amostra macroscópica é estabelecer relações matemáticas entre o sistema de eixos cartesianos da amostra (A) e do cristal (C). Dessa forma, define-se a matriz de orientação g como:

$$
C=g \cdot A
$$

Onde g é uma matriz cujos elementos são os cossenos dos ângulos das direções $<100>$ e cada um dos eixos relacionados à geometria macroscópica da amostra (no caso da chapa laminada, DL, DN e DT). $\alpha_{1}$, por exemplo, é definido como o ângulo entre a direção cristalina [100] e o eixo $\times$ (no caso, DL). $\alpha_{2}$ é definido como o ângulo entre a direção [100] do cristal e o eixo y (no caso DT). Por fim, $\alpha_{3}$ é definido como o ângulo entre a direção [100] e a direção normal DN. As outras duas linhas da matriz são formadas pelos ângulos entre as outras duas direções cristalográficas ([010] e [001]) e os eixos $x, y$ e $z$, gerando uma matriz quadrada de 9 elementos:

$$
g=\left[\begin{array}{lll}
\cos \alpha_{1} & \cos \beta_{1} & \cos \gamma_{1} \\
\cos \alpha_{2} & \cos \beta_{2} & \cos \gamma_{2} \\
\cos \alpha_{3} & \cos \beta_{3} & \cos \gamma_{3}
\end{array}\right]
$$

Algumas propriedades importantes da matriz de rotação são:

1) g é uma matriz ortogonal, isso é a matriz inversa de g é igual à sua transposta.

2) Como a orientação espacial de um cristal é definida por três variáveis independentes, conclui-se que g possui elementos redundantes. De fato, os valores contidos na matriz estão "amarrados", de modo que o produto vetorial entre as duas primeiras linhas (ou colunas) resulta na terceira. 


\subsubsection{A Orientação ideal (índices de Miller - Bravais)}

Uma maneira simplificada de expressar a orientação de um cristal se dá pela utilização dos índices de Miller. Da matriz da orientação (g), nota-se que os valores da primeira coluna (que dão a direção do eixo DL em relação ao sistema de coordenadas do cristal) e da última coluna (que dão a direção do eixo DN em relação ao sistema de coordenadas do cristal) podem ser multiplicados por um número inteiro e depois divididos por um fator comum para a obtenção dos índices de Miller que representem a dada orientação. Seja, por exemplo, a matriz de orientação g dada por:

$$
\left[\begin{array}{ccc}
-0,768 & 0,581 & 0,267 \\
-0,384 & -0,753 & 0,535 \\
0,512 & 0.308 & 0,802
\end{array}\right]
$$

Multiplicando os valores da primeira coluna por $10^{3}$ e reduzindo para os menores inteiros, obtêm-se: -6, -3 e 4. Repetindo o mesmo procedimento para a última coluna (mas desta vez arredondando as casas decimais) obtêm-se 1,2 e 3. Assim, a orientação desse cristal pode ser expressa por (123) [ [634].

Diz-se que um material possui textura quando um elevado número dos grãos que o compõe possui orientação cristalográfica próxima de uma orientação ideal denominada componente. No caso de uma chapa laminada, por exemplo, representase a componente através dos índices de Miller do plano $\{\mathrm{hkl}\}$ paralelo ao plano de laminação da chapa e pela direção <abc> contida no plano $\{\mathrm{hkl}\}$ e paralela à direção de laminação (DL). A Figura 40 ilustra uma chapa metálica que apresenta textura de componente $\{001\}<110>$. Isso é equivalente a dizer que uma grande parcela dos grãos que compõe a chapa possui orientações próximas à mencionada.

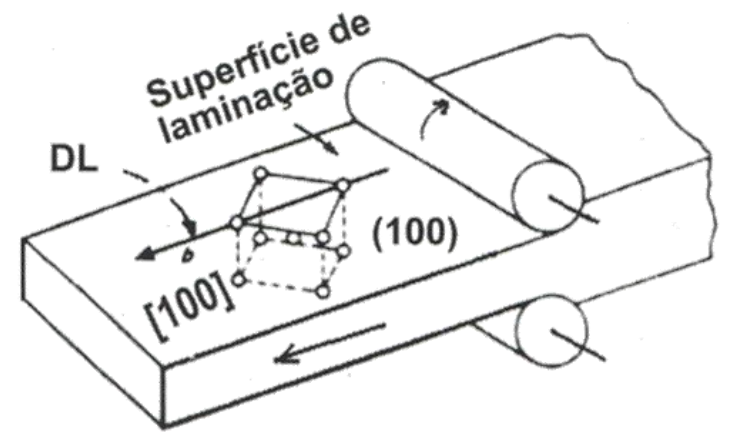

Textura $\{001\}<110>$

Figura 40 - Representação da textura do tipo Cubo Rodado $(\{001\}<110>$ ) em uma chapa metálica laminada [109] 


\subsubsection{Os ângulos de Euler e o espaço de Euler}

Os ângulos de Euller constituem outra maneira de representar a orientação cristalográfica. Através de três rotações consecutivas, faz-se com que o sistema de eixos associado à amostra macroscópica $(A)$ coincida com aquele associado ao cristal (C). Usualmente, as rotações são expressas por três ângulos $\left(\phi_{1}, \Phi, \phi_{2}\right)$ que representam:

- Uma rotação $\phi_{1}$ em torno do eixo DN que transforma o eixo DL em DL' e o eixo DT em DT';

- Uma rotação $\Phi$ em torno $r$ do eixo DL' que transforma DN em DN';

- Uma rotação $\phi_{2}$ em torno do eixo DN'.

As operações descritas são ilustradas na Figura 41.

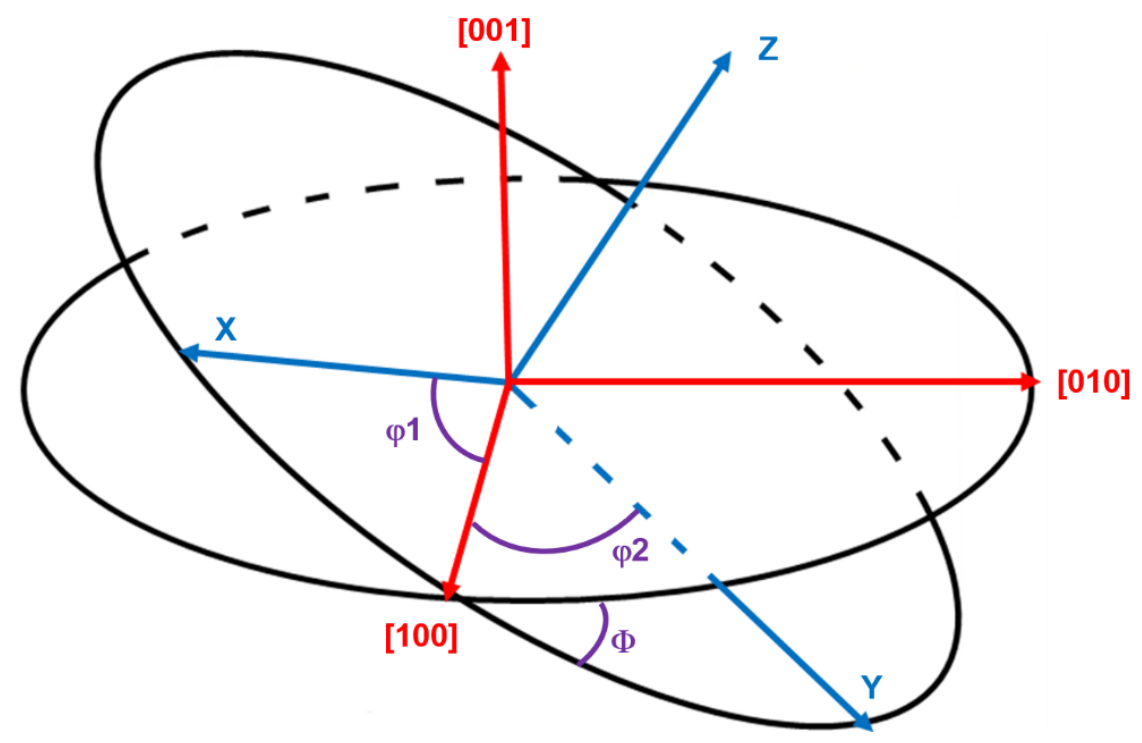

Figura 41 - Representação das rotações $\phi_{1}, \phi_{2}$ e $\Phi$ realizadas de modo a fazer o eixo da amostra coincidir com o eixo do cristal. Adaptado de [110]

A matriz de orientação g pode ser escrita em termos dos ângulos de Euller de acordo com:

$\left[\begin{array}{ccc}\cos \varphi_{1} \cos \varphi_{2}-\operatorname{sen} \varphi_{1} \operatorname{sen} \varphi_{2} \cos \Phi & \operatorname{sen} \varphi_{1} \cos \varphi_{2}+\cos \varphi_{1} \operatorname{sen} \varphi_{2} \cos \Phi & \operatorname{sen} \varphi_{2} \operatorname{sen} \Phi \\ -\cos \varphi_{1} \operatorname{sen} \varphi_{2}-\operatorname{sen} \varphi_{1} \cos \varphi_{2} \cos \Phi & -\operatorname{sen} \varphi_{1} \operatorname{sen} \varphi_{2}+\cos \varphi_{1} \cos \varphi_{2} \cos \Phi & \cos \varphi_{2} \operatorname{sen} \Phi \\ \operatorname{sen} \varphi_{1} \operatorname{sen} \Phi & -\cos \varphi_{1} \operatorname{sen} \Phi & \cos \Phi\end{array}\right]$ 
Onde:

- $0^{\circ} \leq \varphi_{1}, \varphi_{2} \leq 360^{\circ}$

- $0^{\circ} \leq \Phi \leq 180^{\circ}$

Por meio dos ângulos de Euller, é possível expressar uma orientação cristalográfica (sem equívocos) por um ponto em um espaço tridimensional cujos eixos são $\varphi_{1}, \varphi_{2}$ e $\Phi$. O mencionado espaço é denominado Espaço de Euller e é comumente utilizado para representar de maneira gráfica a macrotextura cristalográfica obtidas via difração de raios $X$ ou a microtextura obtida via EBSD. A Figura 42 mostra a representação de uma orientação g (onde $\varphi_{1}=200^{\circ}, \varphi_{2}=250^{\circ}$ e $\Phi=90^{\circ}$ ) no Espaço de Euller.

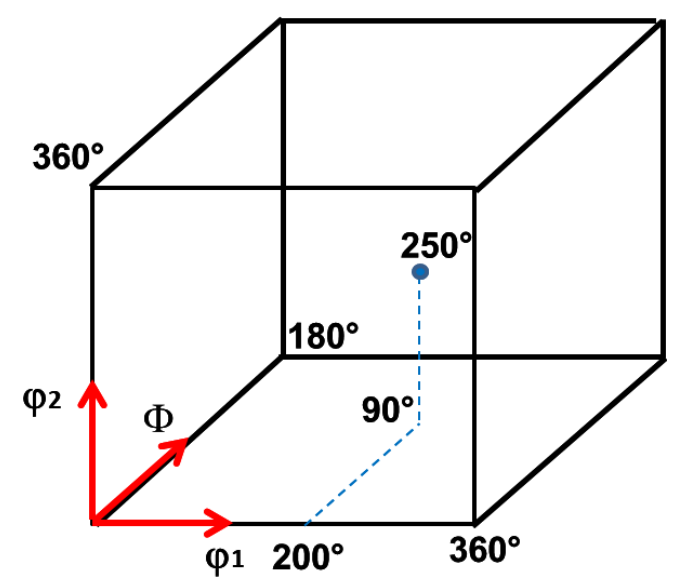

Figura 42 - Exemplo de representação de orientação no Espaço de Euler

\subsubsection{Representação gráfica - projeção estereográfica e figuras de polo}

Embora a descrição matemática e precisa de cada um dos grãos que compõe uma amostra seja um assunto de interesse, a representação gráfica das orientações dos inúmeros grãos que formam esse material é de maior utilidade prática para 0 estudo da textura. Nesse contexto, uma maneira comumente utilizada para a representação das orientações cristalográficas é a utilização das figuras de polo geradas por meio de projeções estereográficas.

Considere uma esfera de raio $\mathrm{R}$ que contém em seu centro um cristal cúbico com uma determinada orientação, conforme representado na Figura 43. Seja também a circunferência que passa pelo equador da esfera anteriormente mencionada. Um dado 
plano cristalográfico contido no cristal é representado por um ponto através do seguinte procedimento:

Projeta-se a direção normal ao plano (que no sistema cúbico tem os mesmos índices de Miller do plano) sob a superfície da esfera de raio R. A intersecção da direção normal ao plano com a esfera determina o ponto $P$.

Liga-se o polo sul da esfera ao ponto $\mathrm{P}$ determinado no procedimento anterior. A intersecção dessa direção com a circunferência equatorial da esfera determina o ponto P'. Tal ponto é a representação do plano cristalográfico em questão.
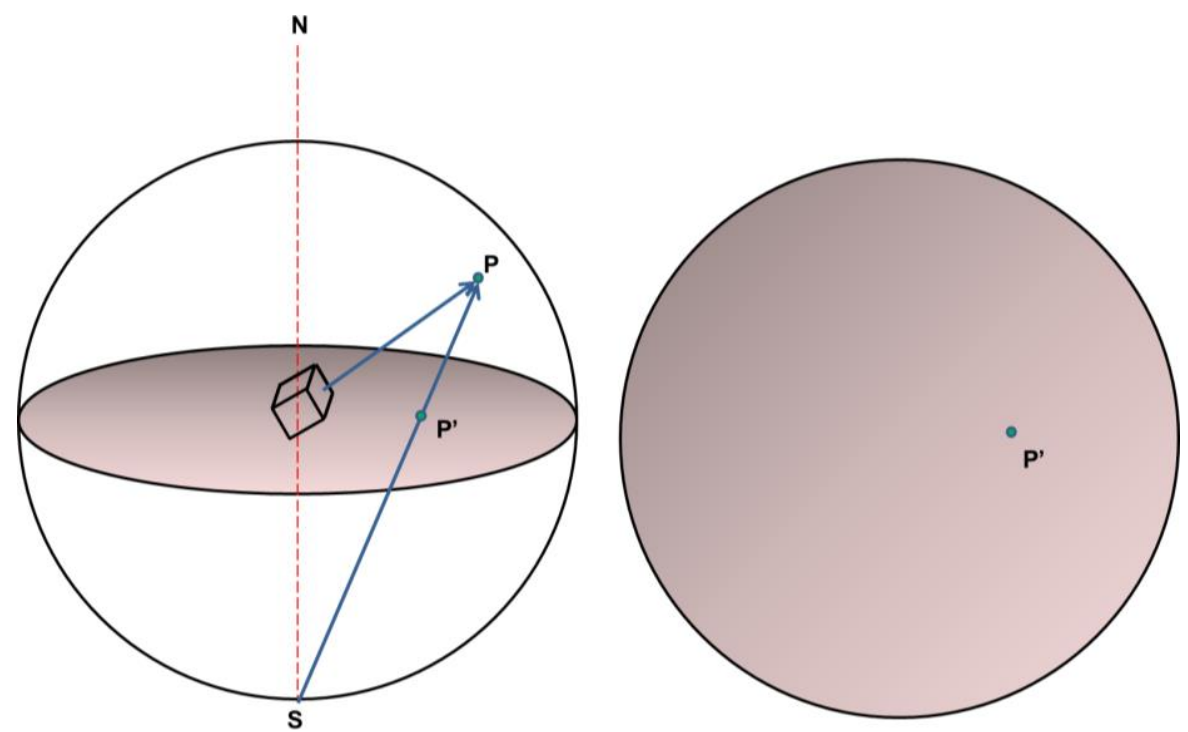

Figura 43 - Projeção de um dado plano cristalino na esfera de referência para formação das figuras de polo

Por meio do procedimento apresentado na Figura 43, constroem-se projeções (chamadas estereográficas) para os principais planos de deslizamento dos sistemas CCC e CFC. A Figura 44 ilustra as mencionadas projeções. As linhas desenhadas dividem a figura em 24 recintos de formato aproximadamente triangular (um desses recintos está pintado em vermelho). Em função da elevada simetria do sistema cúbico, existe equivalência entre qualquer uma das 24 figuras triangulares mencionadas. Assim, utilizando apenas uma dessas figuras (denominada triângulo fundamental de orientações), é possível referir-se a qualquer plano dos sistemas cúbicos. 


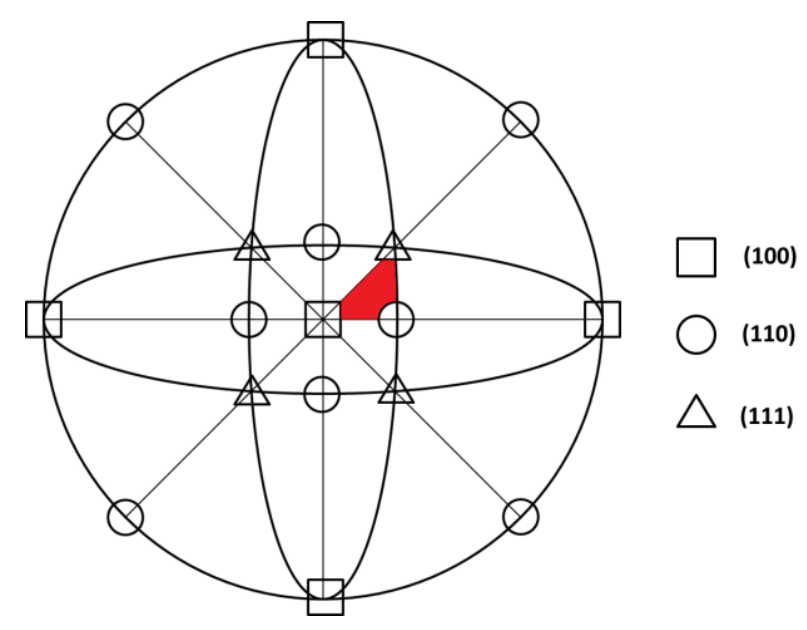

Figura 44 - Representação da projeção estereográfica dos planos cristalinos da família (100), (110) e (111). Em vermelho, está destacado o chamado triângulo fundamental de orientações

- A Figura 45 ilustra um triângulo fundamental de orientações e também as projeções de 5 grãos. Note que, neste exemplo, as orientações dos grãos (em relação à superfície de uma chapa, por exemplo) estão próximas da orientação da família de planos (100).

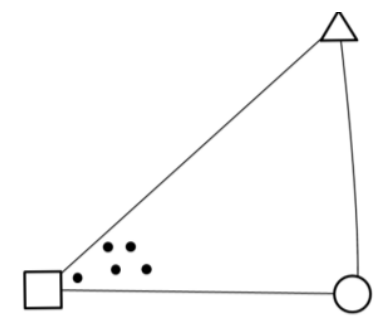

Figura 45 - Projeção da orientação de 5 grãos sobre o triângulo fundamental de orientações

Caso o número de grãos analisados seja elevado, a representação pontual dos planos por meio do triângulo fundamental de orientações se torna inviável. Em casos como este, é comum delimitar por curvas de isonível as regiões que possuem densidades de pontos semelhante, conforme ilustrado na Figura 46. 


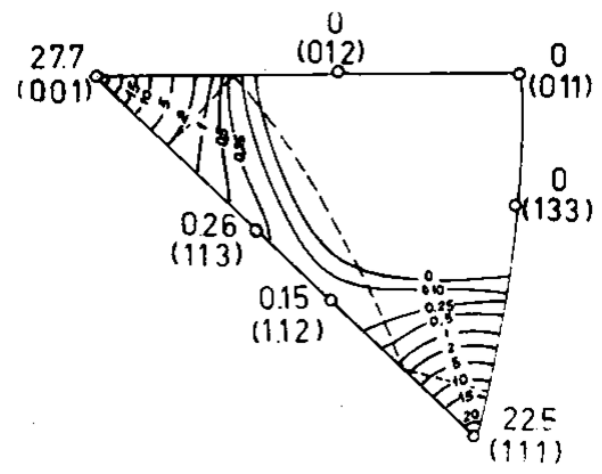

Figura 46 - Representação da orientação cristalina por meio de curvas de isonível plotadas no triângulo fundamental de orientações [111]

A mesma técnica (curvas de isointensidade) pode ser aplicada às próprias figuras de polo, conforme ilustrado na Figura 47 que mostra projeções características de chapas com textura Cubo.

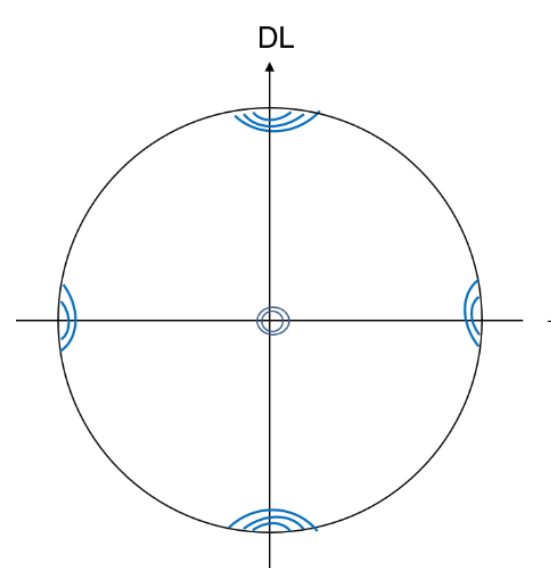

a) (100)

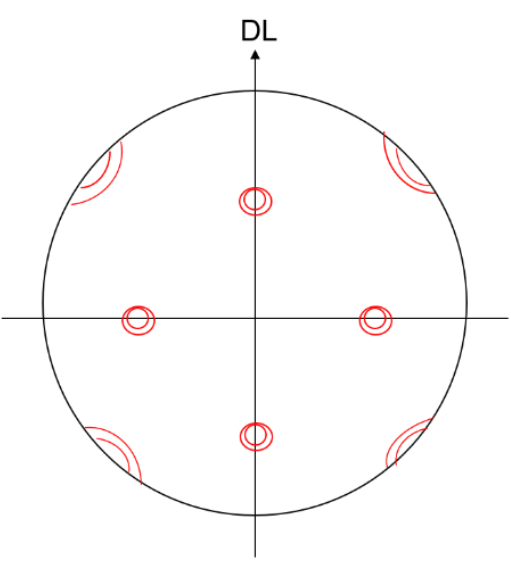

b) (110)

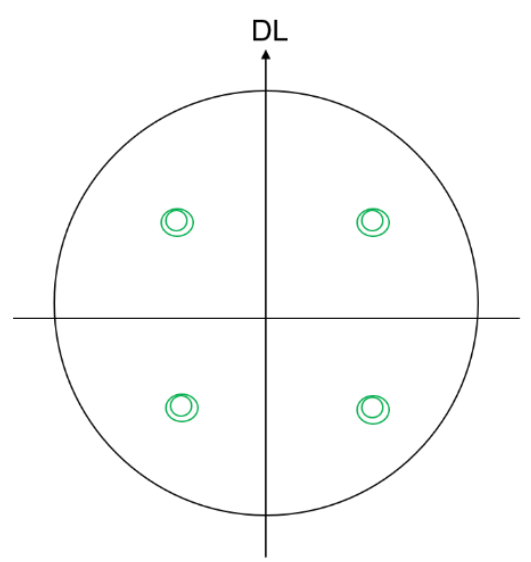

c) (111)

Figura 47 - Figuras de pólo relativas às familias de planos a) (100), b) (110) e c) (111) de um material com forte textura do tipo Cubo. Adaptado de [111]

\subsubsection{Função Distribuição de Orientação (FDO)}

A projeção de uma determinada orientação cristalográfica em um sistema bidimensional (como os mapas de orientação) resulta em perda de informações, de modo que a textura não pode ser completamente descrita. Basta imaginar que os cristais podem ser rotacionados ao redor de um eixo, conforme ilustrado na Figura 48. Observa-se que o plano (001) pode se manter paralelo em relação à superfície de 
laminação de uma chapa, enquanto as direções do cristal (também em relação à direção de laminação da amostra) podem mudar.
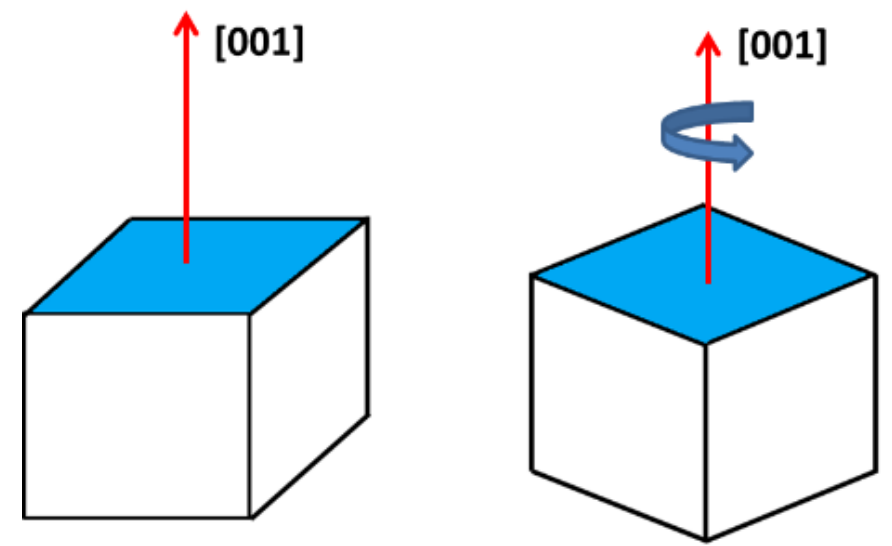

Figura 48 - A rotação de um cristal altera suas direções cristalográficas em relação à amostra macroscópica, enquanto o plano paralelo cristalográfico pode ser manter paralelo à superfície

A interpretação das figuras de polo, por outro lado, pode se mostrar bastante trabalhosa quando há, em determinado material, a presença de duas ou mais componentes de textura.

A função distribuição de orientação (FDO) permite uma avaliação quantitativa da textura cristalográfica por meio de representações gráficas tridimensionais e inequívocas da densidade de orientação dos grãos que formam um material. Em outras palavras, as FDOs indicam a frequência de ocorrência de uma dada componente $\{$ hkl $\}<u v w>$ em uma amostra analisada.

A FDO é definida pela fração volumétrica dos grãos com determinada orientação $g=g\left(\varphi_{1}, \varphi_{2} \Phi\right)$ de acordo com:

$$
\frac{d V}{V}=f(g) \cdot d g
$$

Onde:

$$
d g=\frac{1}{8} \pi^{2} \operatorname{sen} \Phi \mathrm{d} \varphi_{1} \cdot \mathrm{d} \Phi \cdot \mathrm{d} \varphi_{2}
$$

E $f\left(\varphi_{1}, \varphi_{2} \Phi\right)$ pode ser expressa por funções denominadas harmônicos esféricos. Maior detalhamento matemático acerca de tais funções foge ao escopo deste texto e pode ser encontrado no trabalho de Bunge [112]. 
A partir das figuras de polo obtidas por DRX (medidas de macrotextura) ou usando-se a técnica de EBSD (medidas de microtextura) são estimadas as FDOs, em posse das quais a determinação das componentes de textura pode ser realizada.

Comumente, as FDOs são representadas no espaço de Euller. Para facilitar a visualização das componentes de textura, em geral se utiliza uma representação em duas dimensões fixando-se o ângulo $\varphi 2$ e representando a seção resultante por meio de curvas de isointensidade. A Figura 49 ilustra o Espaço de Euller, as seções de constante e a representação das texturas tipo Goss e Latão.

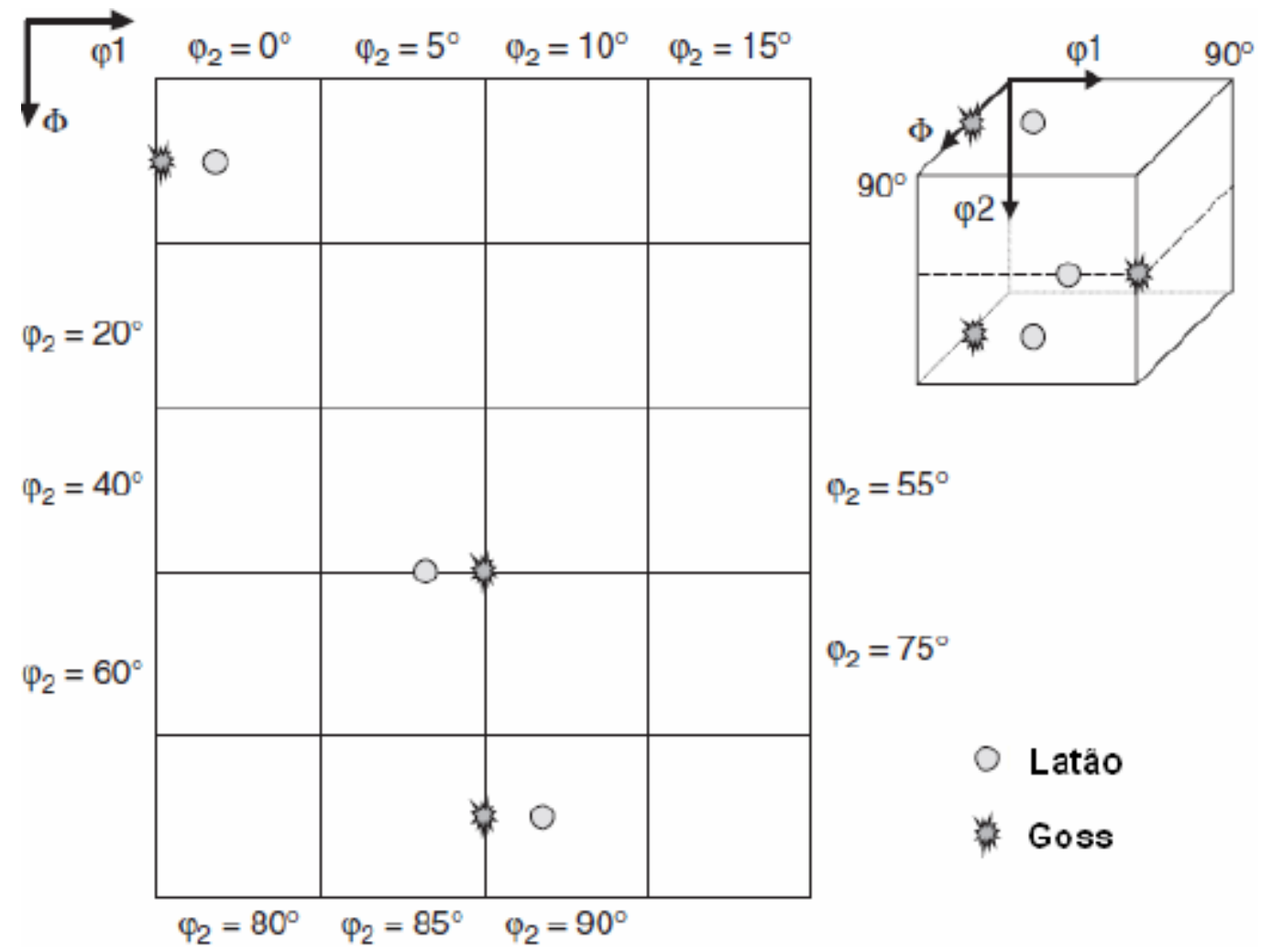

Figura 49 - Representação das componentes Latão e Goss no Espaço de Euller. Para facilitar a visualização, são plotadas seções de $\varphi 2$ constante em intervalos de $5^{\circ}$ [113]

Em geral, são utilizados ábacos auxiliares, como os mostrados na Figura 50, para auxiliar a interpretação dos resultados obtidos. 

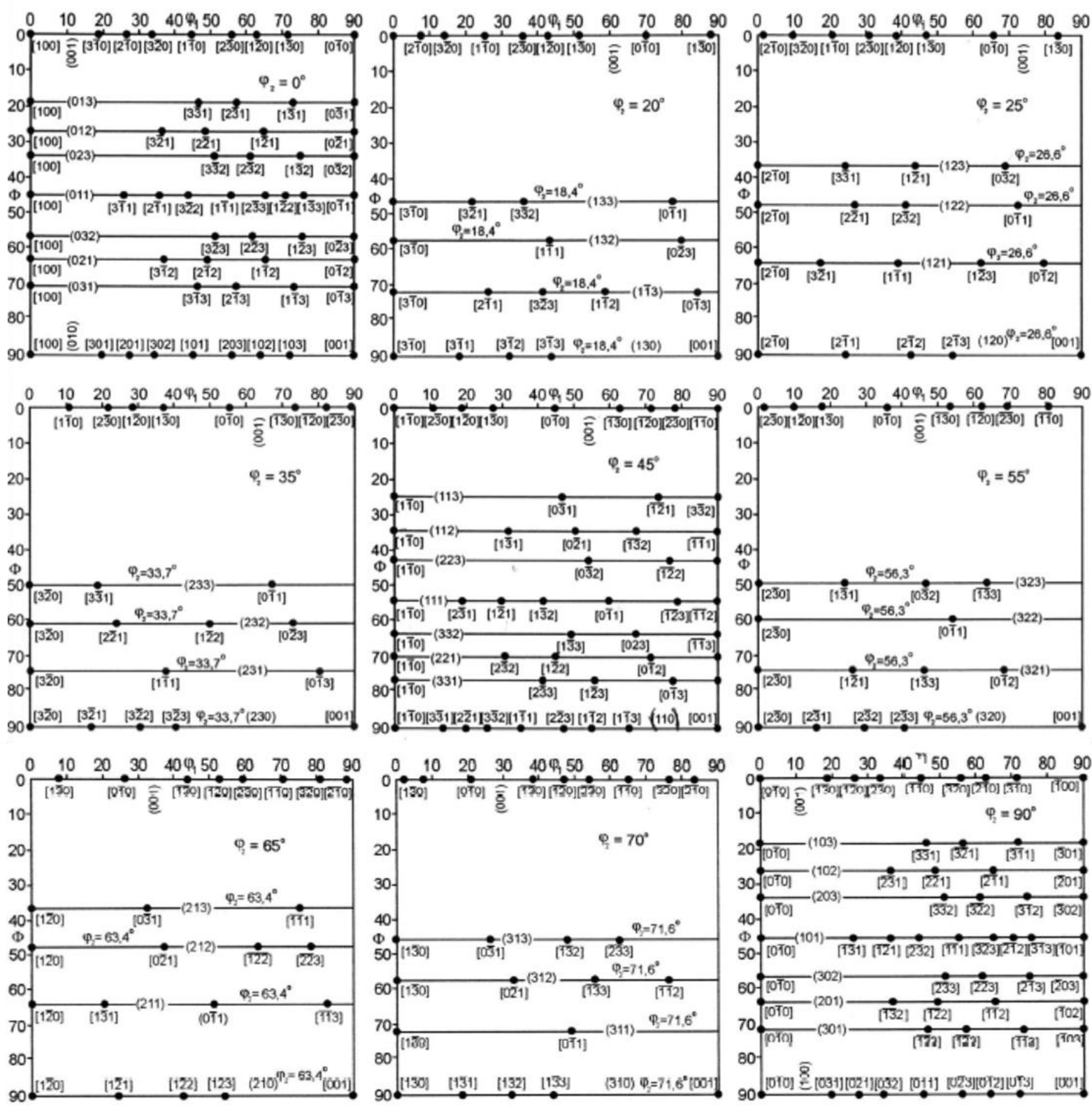

Figura 50 - Ábaco auxiliar para interpretação das FDO's. [112]

\subsubsection{Textura cristalográfica dos metais CFC}

A textura cristalográfica dos metais CFC pode ser mais bem visualizada com a ajuda das chamadas fibras; linhas cujos eixos são descritos por determinadas direções, em geral paralelas à direção de laminação ou à direção normal de laminação. Por exemplo, no caso dos metais CFC existe a chamada fibra $\alpha$, um segmento de reta paralelo à $\varphi_{1}$ e contido no plano definido pelos eixos $\varphi_{1}$ e $\phi$ no espaço de Euler. A Figura 51 ilustra a localização espacial das duas principais fibras ( $\alpha$ e $\beta$ ) definidas para metais CFC. Também estão assinaladas as principais componentes 
associadas à deformação desses materiais. A Fibra $\alpha$ compreende o segmento que se origina da componente Goss $\{011\}<100>$ e encerra-se na componente Latão $\{011\}$ $<211>$. A Fibra $\beta$ "origina-se da componente Latão e "encerra-se até a componente Cobre $\{112\}<111>$ passando pela componente $S\{123\}<634>$.

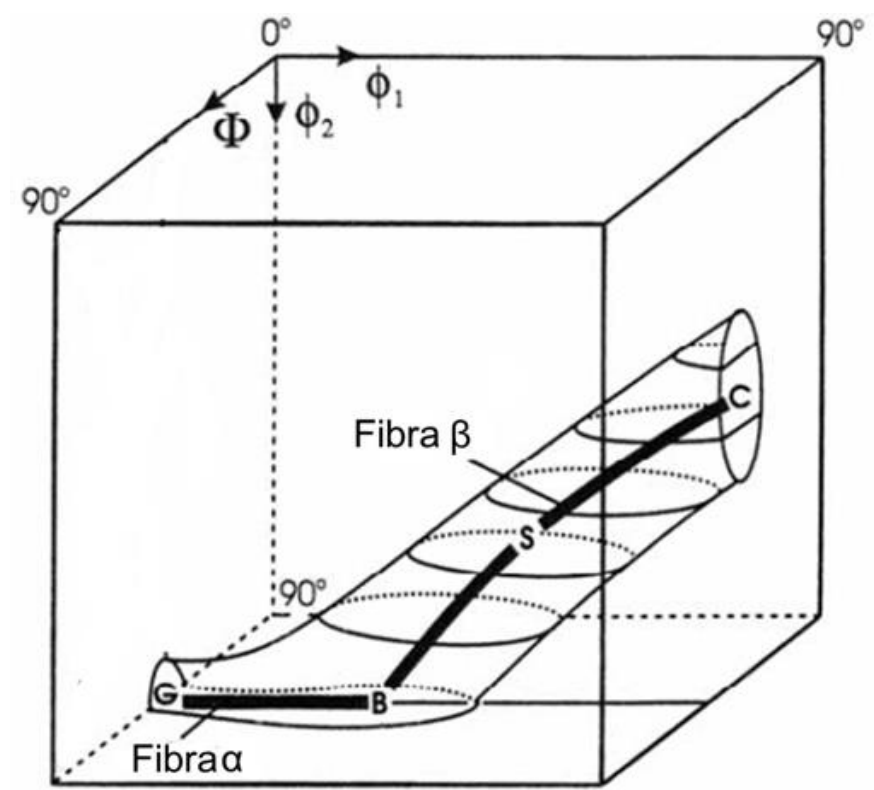

Figura 51 - Localização espacial das principais fibras do sistema CFC no Espaço de Euller. [108]

A textura de deformação de amostras metálicas com estrutura CFC tende a apresentar componentes que se acumulam nas vizinhanças das fibras $\alpha$ e $\beta$ [110]. Baixos graus de deformação tendem a gerar componentes ao redor da fibra $\alpha$, enquanto graus mais elevados de deformação tendem a dar origem à componentes ao redor da fibra $\beta$.

A predominância da componente de textura dos metais CFC é função, principalmente, da energia de falha de empilhamento (EFE) do material em questão. Materiais CFC de baixa EFE tendem a apresentar textura do tipo Latão quando deformados, enquanto materiais de EFE elevada tendem a apresentar a textura do tipo Cobre. A Figura 52 mostra a variação de $\mathrm{f}(\mathrm{g}) \operatorname{com}$ 甲2 (ou seja, a variação ao longo da fibra $\beta$ ) para o cobre puro, e para a ligas cobre-zinco (ambos laminados com 95\% de redução de espessura). Sabe-se que a presença de elementos de liga tende a promover a queda da EFE em relação ao material puro. Nota-se, dessa forma, como o abaixamento da EFE favorece a formação da chamada componente Latão e da componente Cobre e da componente S. 


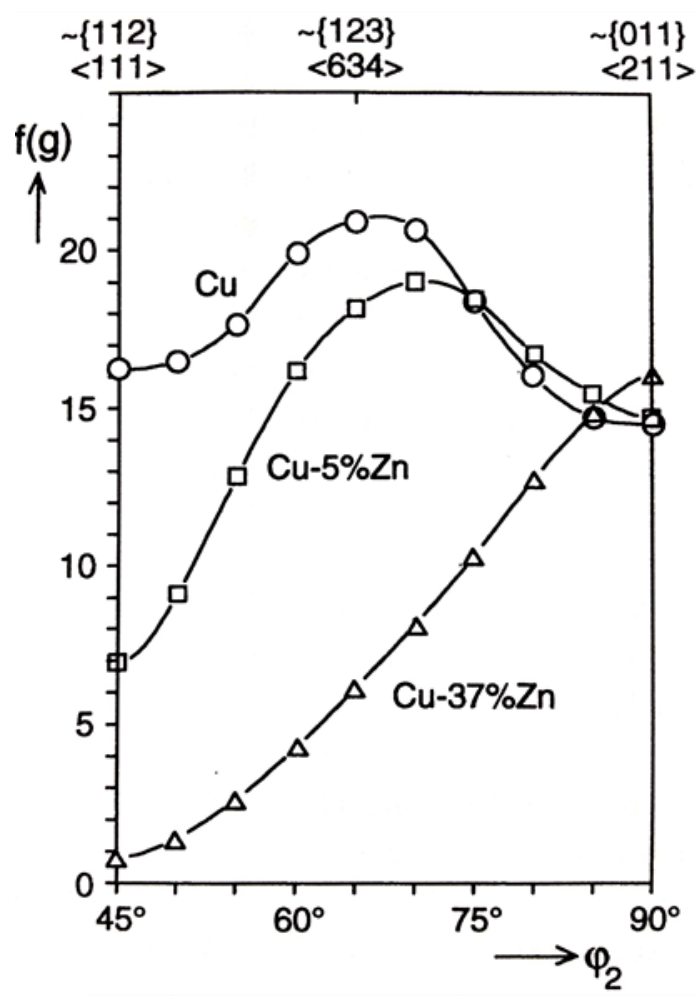

Figura 52 - Variação de $\mathrm{f}(\mathrm{g})$ com $\varphi_{2}$ para o cobre de elevada pureza e para duas ligas cobre zinco com diferentes teores de zinco. Nota-se que a adição de elementos de liga altera a textura de deformação das ligas em relação aos metais puros [114] (EXEMPLO COM AL)

Em relação à textura do material recozido, entende-se que esta é fortemente dependente do grau de deformação e do tempo e temperatura de tratamento térmico. Recozimentos realizados em temperaturas mais baixas em ligas de alumínio tendem a promover o fenômeno de recuperação, que pouco altera a textura cristalográfica do material [115]. O recozimento de materiais metálicos (suficientemente deformados) em temperaturas mais altas, por outro lado, propicia a ocorrência da recristalização. Nesse caso, a textura pode:

1) Não se alterar, isso é, a textura resultante da recristalização se mantém muito similar à textura de deformação prévia;

2) Dar origem a uma textura intensa, de componentes completamente diferentes daquelas geradas pelo processo de deformação;

3) Não se desenvolver, gerando assim, um material "livre" de textura, ou de componentes de textura muito fracas.

A ausência de textura (colocada no item 3) é incomum e raramente observada, ocorrendo em materiais processados por rotas alternativas, como a metalurgia do pó 
e similares [116]. Em relação aos itens 2 e 3, os mecanismos ligados à ocorrência de um fenômeno ou de outro ainda não são totalmente compreendidos, existindo atualmente duas teorias concorrentes que buscam explicar cada um deles: A teoria da nucleação orientada (item 1, que estabelece que a textura do material é determinada no momento em que ocorre a nucleação de novos grãos) e a teoria do crescimento orientado (item 2, que assume a formação de núcleos com orientações diversas, sendo que apenas alguns deles, com orientações específicas, crescem e determinam a textura do material) [115].

A Tabela 7 apresenta um resumo das principais componentes de textura encontradas em metais CFC, sua orientação em termos dos ângulos de Euler e os processos termomecânicos que tendem a promover a formação tais componentes.

Tabela 7 - Índices de Miler e ângulos de Euler das principais componentes de textura encontradas em metais e ligas de estrutura CFC [108], [117]

\begin{tabular}{cccc}
\hline Nome da Orientação & $\begin{array}{c}\text { Orientação Ideal } \\
\{\text { hkl }\}<\text { uvw }>\end{array}$ & $\begin{array}{c}\text { Possíveis } \\
\text { Ângulos de Euler } \\
\varphi 1, \Phi, \varphi 2\end{array}$ & Associada à \\
\hline C, Cobre & $\{112\}<111>$ & $90^{\circ}, 35^{\circ}, 45^{\circ}$ & Laminação \\
S & $\{123\}<634>$ & $59^{\circ}, 37^{\circ}, 63^{\circ}$ & Laminação \\
B, Latão & $\{011\}<211>$ & $35^{\circ}, 45^{\circ}, 0^{\circ}$ & Laminação \\
G, goss & $\{011\}<100>$ & $0^{\circ}, 45^{\circ}, 0^{\circ}$ & Laminação \\
Cubo & $\{001\}<100>$ & $0^{\circ}, 0^{\circ}, 0^{\circ}$ & Recristalização \\
Cubo Rodado & $\{001\}<110>$ & $45^{\circ}, 0^{\circ}, 0^{\circ}$ & Recristalização \\
\hline
\end{tabular}




\section{MATERIAIS E MÉTODOS}

Nesse capítulo são descritos os materiais estudados, assim como os métodos experimentais utilizados.

\subsection{Materiais utilizados}

As amostras da AA 7108 foram extraídas tanto dos lingotes cilíndricos de 200 $\mathrm{mm}$ de diâmetro (nos estados bruto de solidificação e homogeneizado a $480^{\circ} \mathrm{C}$ por 4 horas) quanto de barras extrudadas a quente (a partir desses lingotes) de $15 \mathrm{~mm}$ de espessura. Para o corte das tiras a partir das barras, foi utilizada uma máquina de corte por jato d'água, localizada no Departamento de Engenharia de Minas da Escola Politécnica. Para cortes posteriores, utilizou-se uma cortadeira de precisão da marca Struers localizada no Laboratório de Transformação de Fases do Departamento de Engenharia Metalúrgica e de Materiais da Escola Politécnica.

A Tabela 8 mostra a composição química da liga AA 7108 (obtida via espectrofotometria óptica realizada na Companhia Brasileira de Alumínio) utilizada no presente trabalho.

Tabela 8 - Composição da AA 7108 utilizada no presente trabalho

\begin{tabular}{ccccccccc}
\hline Ti & Mn & Si & Cr & Fe & Mg & Zr & Zn & Al \\
\hline 0,05 & - & 0,05 & 0,01 & 0,10 & 1,03 & 0,20 & 4,96 & Balanço \\
\hline
\end{tabular}

\subsection{Caracterização do material como recebido}

A liga AA 7108 (bruta de solidificação, homogeneizada e extrudada) foi caracterizada com auxílio das técnicas experimentais descritas a seguir (Sendo que as amostras no estado bruto de solidificação e homogeneizado foram caracterizadas apenas pelas técnicas descritas entre os tópicos 3.2.1 e 3.2.5). 


\subsubsection{Condutividade elétrica}

A condutividade elétrica da AA 7108 foi medida com emprego de um condutivimetro, marca Zappi, modelo DC-11M, localizado no Departamento de Engenharia Metalúrgica e de Materiais da Escola Politécnica.

As medidas foram tomadas com relação ao cobre de alta pureza recozido: o chamado IACS (International Annealed Copper Standard). Isso significa que uma dada liga de alumínio com 50 IACS possui $50 \%$ da condutividade elétrica do cobre de alta pureza recozido.

Para cada amostra foram realizadas três medidas. O padrão de calibração usado foi o da liga de alumínio de 59,4\% IACS, fornecido pela Zappi juntamente com o condutivimetro.

\subsubsection{Preparação metalográfica}

A preparação metalográfica das amostras para os ensaios de microscopia óptica, microscopia eletrônica de varredura e EBSD foi realizada seguindo o procedimento descrito a seguir. As amostras foram lixadas com lixas de carboneto de silício (SiC) de granulometria 220, 400, 800 e 1200 e então lavadas com água destilada e secas. Em seguida, utilizando-se pastas diamantadas na sequência $6 \mu \mathrm{m}$, $3 \mu \mathrm{m}$ e $1 \mu \mathrm{m}$, foi realizado um polimento inicial. Por fim, com emprego da politriz automática MINIMET (localizada no Laboratório de Transformação de Fases do Departamento de Engenharia Metalúrgica e de Materiais da Escola Politécnica) e de sílica coloidal $(0,06 \mu \mathrm{m})$ foi realizada a etapa final de polimento.

\subsubsection{Microscopia óptica de luz polarizada (M.O)}

As amostras preparadas conforme descrito na seção 3.2.2 foram anodizadas com solução de $\mathrm{HBF}_{4} 1,8 \%$ e fonte de $20 \mathrm{~V}$ com anodo da liga AA 1050 para revelar a estrutura de grãos. As amostras anodizadas foram analisadas com auxílio de um microscópio óptico com polarizador de luz, marca Olympus BX51M, localizado na empresa CBA em Alumínio - SP. 


\subsubsection{Microscopia eletrônica de varredura (MEV)}

Análises por microscopia eletrônica de varredura foram realizadas em em um microscópio modelo FEI - Inspect 50, localizado no Departamento de Engenharia Metalúrgica e de Materiais da Escola Politécnica. Foram obtidas imagens nos modos elétrons retroespalhados e elétrons secundários, além de análises químicas de microrregiões que foram realizadas via espectroscopia de energia dispersiva (EDS).

\subsubsection{Dureza Vickers}

Ensaios de dureza Vickers foram realizados ao longo da superfície de extrusão da liga AA 7108 no estado como recebido, nas amostras bruta de solificação, homogeneizada e nas amostras posteriormente processadas por tratamentos termomecânicos. As medidas foram tomadas em um microdurômetro da marca Shimadzu, localizado no Laboratório de Microscopia Eletrônica e de Força Atômica do Departamento de Engenharia Metalúrgica e de Materiais da Escola Politécnica. A carga utilizada foi $100 \mathrm{~g}$ e foram tomadas 15 medidas por amostra.

Foram também realizados ensaios de dureza Vickers utilizando carga de $100 \mathrm{~g}$ em equipamento automatizado da marca Emco-test com penetrador piramidal. $\mathrm{O}$ microdurômetro em questão está localizado no Laboratório de Soldagem e Junção do Departamento de Engenharia Metalúrgica e de Materiais da Escola Politécnica.

\subsubsection{Difratometria de raios $X$}

Uma amostra da AA 7108 (em formato de paralelepípedo de dimensões $15 \mathrm{~mm}$ $\times 15 \mathrm{~mm} \times 5 \mathrm{~mm}$ ) no estado como recebido teve sua superfície preparada através de polimento mecânico e foi submetida à análise por difração de raios $\mathrm{X}$. $\mathrm{O}$ experimento foi conduzido no equipamento PANalytical, modelo X'PERT, instalado no Laboratório de Caracterização Tecnológica, localizado no Departamento de Engenharia de Minas da Escola Politécnica. $\mathrm{O}$ equipamento mencionado apresenta como fonte de raios $\mathrm{X}$ um tubo que emitia a radiação CuKa $(\lambda=1,542 \AA)$ 


\subsubsection{Textura cristalográfica (via EBSD)}

Amostras da liga AA 7108 foram cortadas ao longo da espessura, conforme ilustrado esquematicamente na Figura 53, e tiveram suas superfícies preparadas conforme descrito na seção 3.2.2. Para estudo da microtextura, foi utilizada a técnica de EBSD, cujo detector estava acoplado ao microscópio eletrônico modelo FEl Inspect F50, localizado no Departamento de Engenharia Metalúrgica e de Materiais da Escola Politécnica.

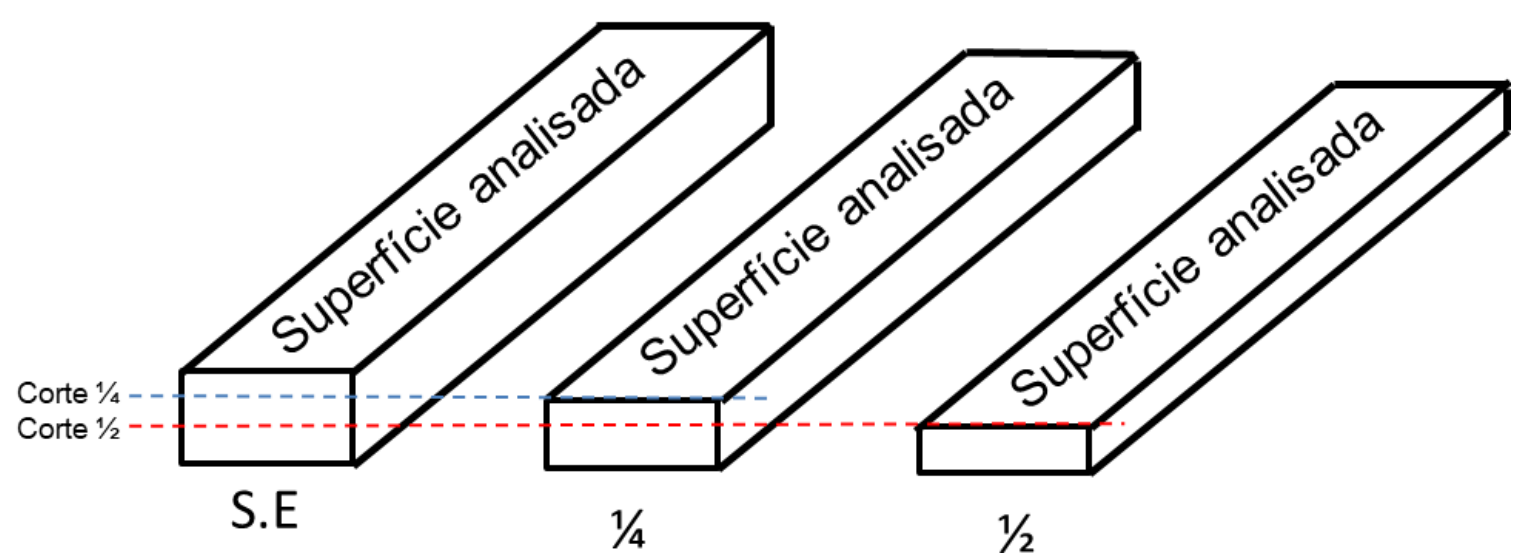

Figura 53 - Representação dos cortes realizados nas amostras das barras extrudadas de AA 7108. A macrotextura foi estudada nas três superfícies indicadas.

\subsubsection{Textura cristalográfica (via difratometria de raios $\mathrm{X}$ )}

Para estudo da macrotextura, utilizou-se um difratômetro da marca Rigaku, modelo DMAX 2000, com goniômetro de textura horizontal acoplado. O difratômetro está localizado no CCTM - IPEN - São Paulo. A análise foi realizada com emprego do software PAT (Programa de Análise de Textura), desenvolvido por Galego [118]. Além de gerar as figuras de polo das principais famílias de planos dos metais CFC, também foi possível obter as funções densidade de orientação (FDO) para cada superfície de cada liga analisada.

\subsection{Tratamentos termomecânicos}

As próximas seções descrevem os tratamentos termomecânicos a que as amostras da liga AA 7108 foram submetidas. 


\subsubsection{Solubilização e envelhecimento}

As amostras da AA 7108 foram inicialmente tratadas a $490^{\circ} \mathrm{C}$ por 5 horas em forno mufla localizado no Departamento de Engenharia Metalúrgica e de Materiais da Escola Politécnica. Ao final das 5 horas, as amostras foram retiradas do forno e resfriadas rapidamente na mistura água + gelo $\left(0^{\circ} \mathrm{C}\right)$. Tal tratamento tinha como objetivo promover a solubilização dos intermetálicos causadores do endurecimento por precipitação, o que promove o aumento a ductilidade do material, facilitando a etapa seguinte de laminação.

Após o tratamento térmico descrito anteriormente, foram tomadas medidas de dureza Vickers e de condutividade elétrica das amostras solubilizadas. Tais medições foram refeitas e registradas a cada 12 horas para analisar a ocorrência de envelhecimento natural.

\subsubsection{Laminação das tiras}

As tiras solubilizadas da AA 7108 foram (logo após o quenching) deformadas em laminador duo reversível instalado no Departamento de Engenharia Metalúrgica e de Materiais da Escola Politécnica. Com o objetivo de minimizar os efeitos do envelhecimento natural, as amostras eram mergulhadas em água imediatamente após cada passe. O laminador possuía rolos de diâmetro $50 \mathrm{~mm}$.

Foram realizadas duas reduções de espessura - 33,7\% e 63.6\% - variando-se o número de passes de laminação para cada redução. Foi também calculada a deformação verdadeira (e a acumulada) após cada passe. Além disso, os passes foram realizados de modo a manter o fator delta $(\Delta)$ menor que 1 , o que aproxima 0 processo de um estado homogêneo de deformação. As técnicas de caracterização descritas anteriormente foram utilizadas para caracterizas as tiras laminadas. Os valores de redução foram escolhidos em função de experimentos de prospecção realizados anteriormente. Observou-se que reduções de espessura maiores que $70 \%$ promoviam o surgimento de trincas perpendiculares à direção de laminação. 


\subsubsection{Recozimento das tiras}

As amostras deformadas conforme descrito no tópico 3.3.2 foram submetidas a recozimento em forno mufla localizado no Departamento de Engenharia Metalúrgica e de Materiais da Escola Politécnica. A temperatura adotada foi $490^{\circ} \mathrm{C}$ por 1 e 14 horas. O material recozido foi novamente caracterizado com as técnicas experimentais descritas anteriormente.

A Figura 54 mostra um fluxograma resumindo as etapas experimentais realizadas a partir da AA 7108 extrudada. Informações de caráter descritivo ou acerca dos parâmetros de processamento são apresentadas ao lado dos blocos do fluxograma. 


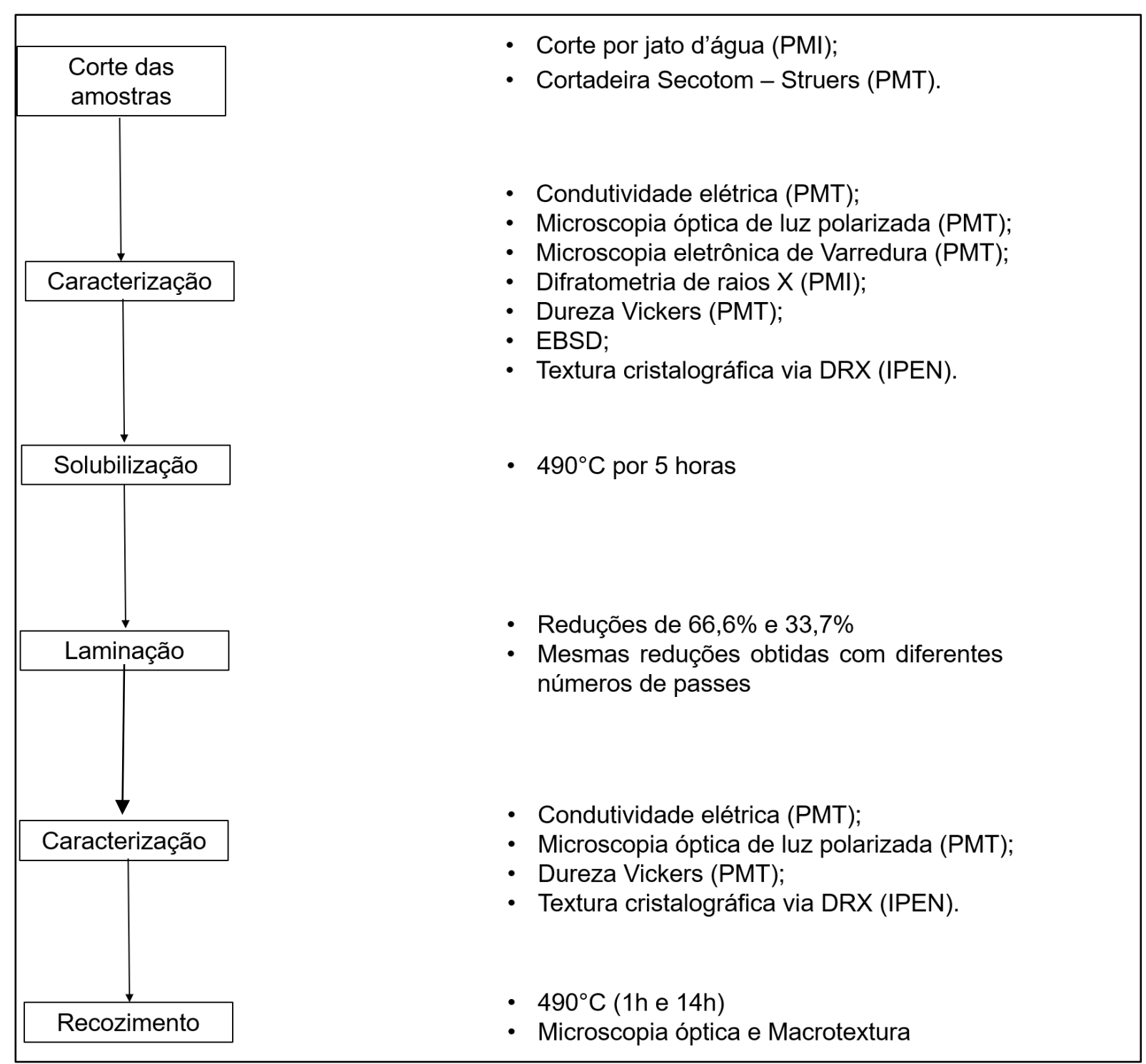

Figura 54 - Fluxograma resumo dos procedimentos experimentais realizados a partir das amostras de AA 7108 extrudadas. 


\section{RESULTADOS E DISCUSSÃO}

Os resultados e discussões serão divididos e apresentados conforme indicado a seguir:

- Caracterização microestrutural, medição de dureza Vickers e da condutividade elétrica das amostras brutas de solidificação e homogeneizadas.

- Caracterização microestrutural, medição de dureza Vickers e obtenção da macro e microtextura cristalográfica das amostras extrudadas.

- Caracterização microestrutural, medição de dureza Vickers e obtenção da macrotextura cristalográfica das amostras solubilizadas e laminadas 33,7\% e 63,6\% em redução de espessura.

- Caracterização microestrutural, medição de dureza Vickers e obtenção da macrotextura cristalográfica das amostras recozidas após laminação.

\subsection{Caracterização microestrutural das amostras fundidas e homogeneizadas}

O presente tópico apresenta os resultados de caracterização das amostras provenientes dos lingotes da AA 7108 nos estados bruto de solidificação e homogeneizado. Embora a avaliação da microestrutura do material nos mencionados estados não seja o objetivo principal desse estudo, ela pode tanto motivar estudos futuros relacionados a esse material, como também pode auxiliar a compreensão de resultados que serão descritos e discutidos a posteriori.

A Figura 55 mostra macrografias da liga AA 7108 para o estado bruto de solidificação e homogeneizado. A olho nu, observa-se uma estrutura isenta de macro defeitos de solidificação (o que foi confirmado com auxílio de uma lupa) e de granulação bastante refinada, sem diferenças notáveis em relação ao tamanho dos grãos na periferia e no centro da amostra. Ainda a olho nu, nota-se um ligeiro aumento do tamanho de grão após homogeneização. Tal crescimento pode ser atribuído ao crescimento de grão ocorrido durante o tratamento térmico para homogeneizar o material bruto de solidificação. 


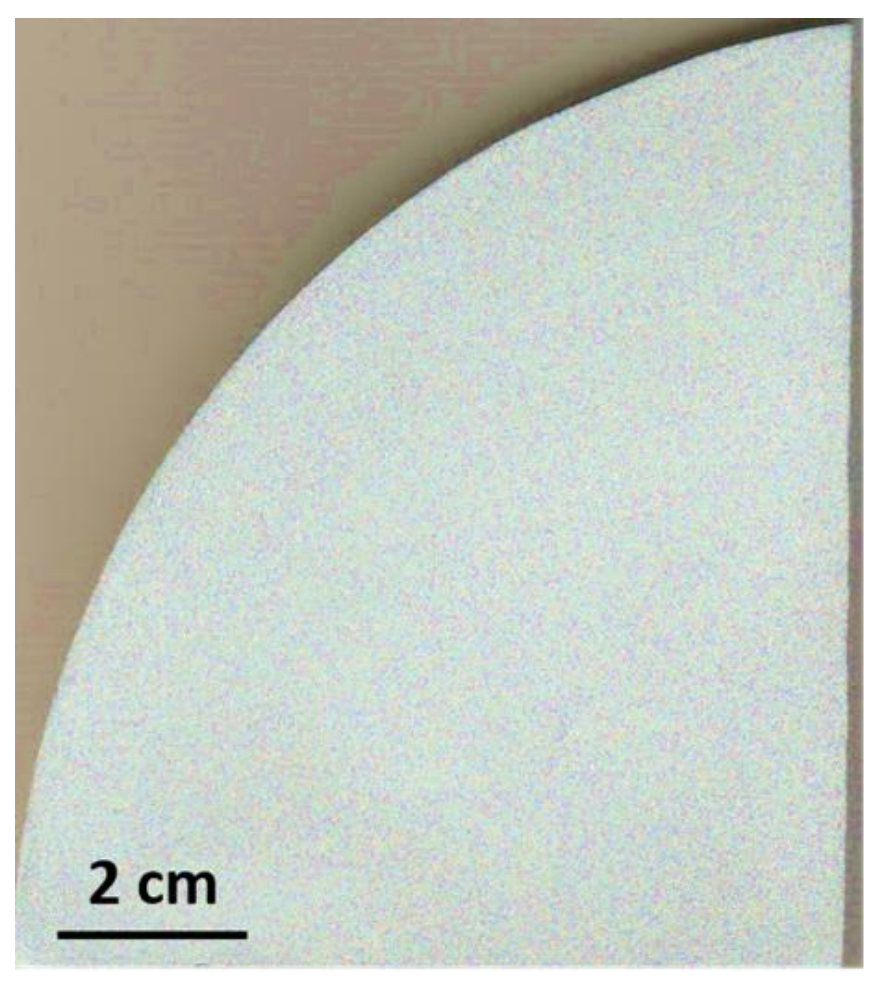

(a)

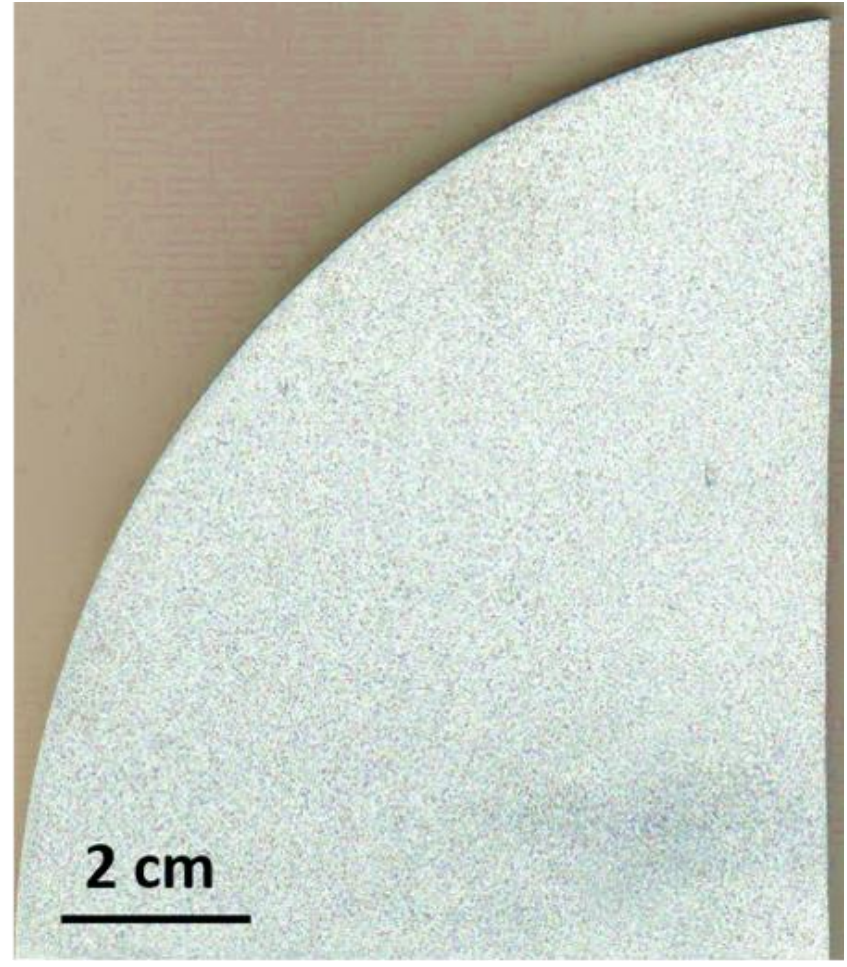

(b)

Figura 55 - Macrografias das seções transversais dos lingotes da liga AA 7108 nas condições (a) bruta de solidificação e (b) homogeneizada. Obtidas por meio de ataque com reagente de Tucker

As Figuras 56 e 57 mostram micrografias obtidas por microscopia óptica de luz polarizada da AA 7108 nos estados bruto de solidificação e homogeneizado, respectivamente. São também indicados os valores médios de dureza Vickers e condutividade elétrica associados às respectivas amostras. A diferença entre 0 tamanho dos grãos entre as amostras pode observada por meio da comparação entre as micrografias: enquanto a amostra bruta de solidificação apresenta tamanho de grão médio de aproximadamente $140 \mu \mathrm{m}$, a amostra homogeneizada apresenta granulação mais grosseira (valor médio próximo de $200 \mu \mathrm{m}$. A observação por microscopia óptica também evidencia que os grãos localizados na região mais central do lingote têm dimensões similares aos grãos periféricos. Tal fenômeno pode ser explicado ao se considerar os teores de Ti e Zr presentes na composição da AA 7108. Tais elementos possuem papel de refinadores de grão [19] e, dessa forma, é possível que impeçam que o tamanho dos grãos centrais difira significativamente do tamanho dos grãos periféricos. 
Os comportamentos observados sugerem que um futuro estudo eletroquímico sistemático sobre o efeito do tratamento térmico de homogeneização será muito oportuno. 

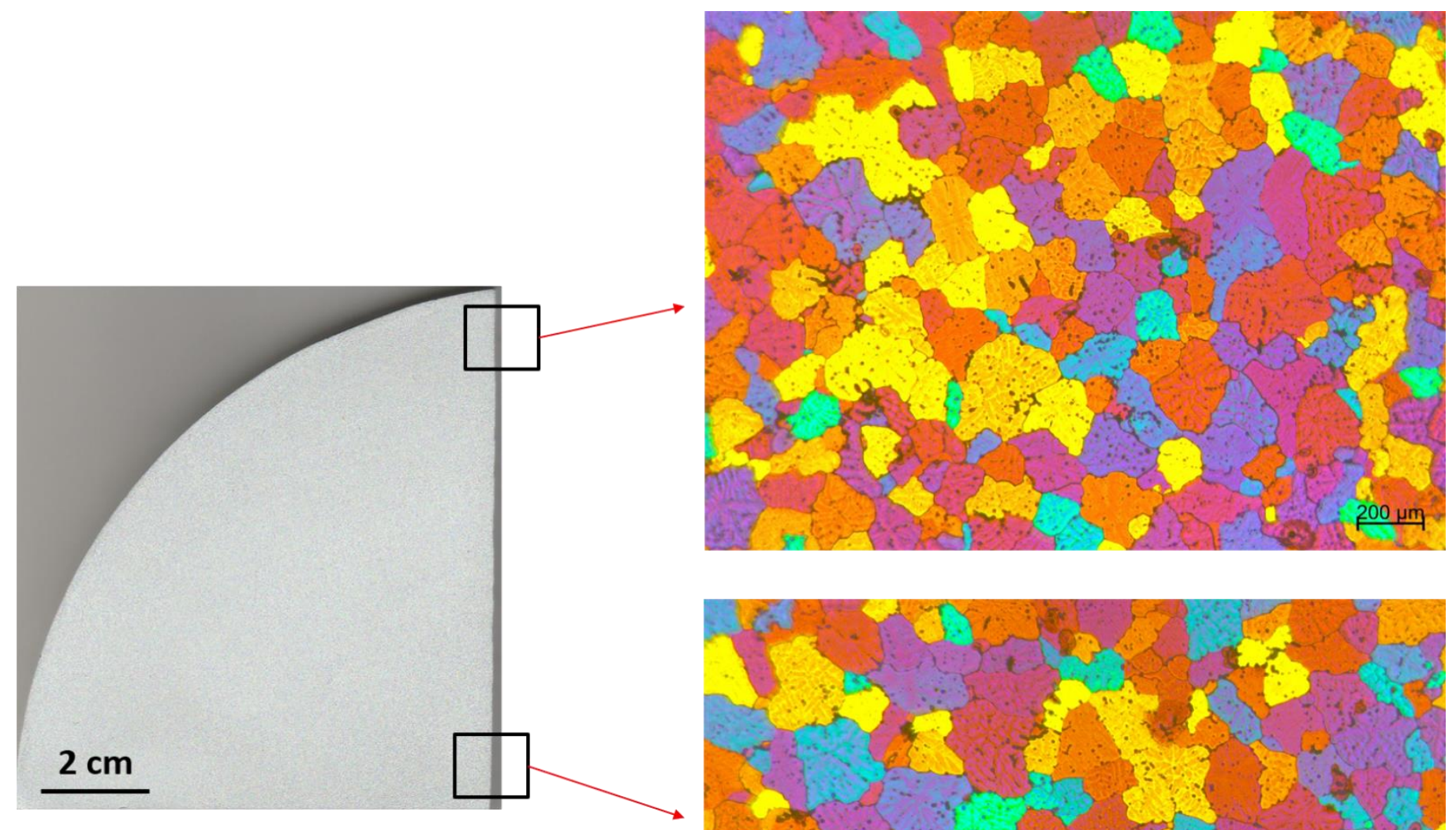

- $121,9 \pm 3,5 \mathrm{HV}$

- $40,0 \%$ IACS

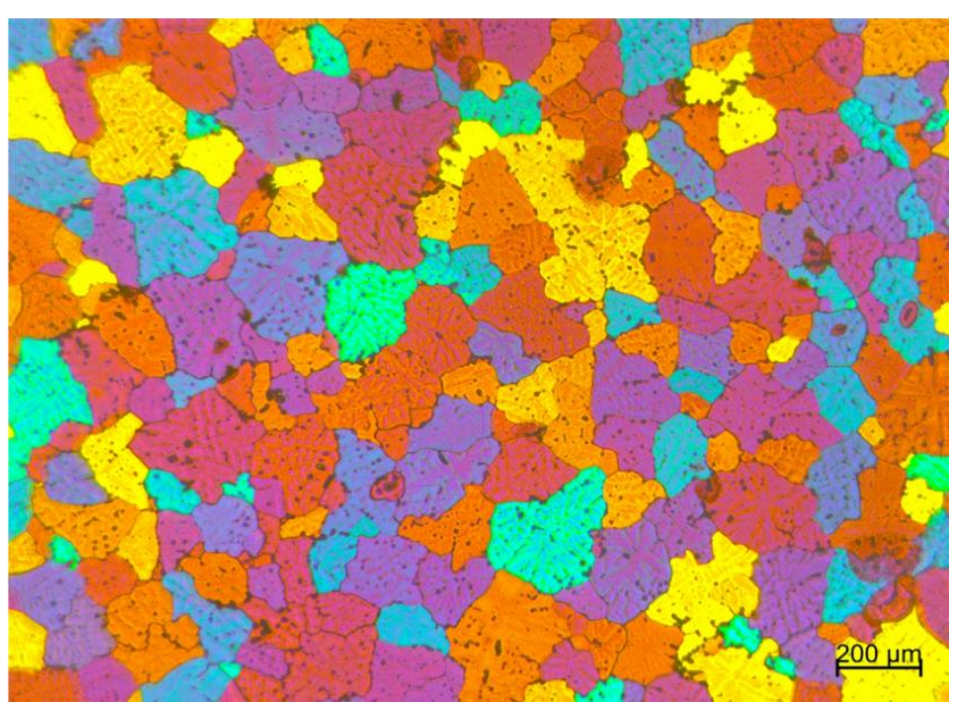

Figura 56 - Micrografias ópticas obtidas com auxílio de luz polarizada das amostras brutas de solidificação. As setas relacionam a micografia com o local em que foram extraídas as amostras 

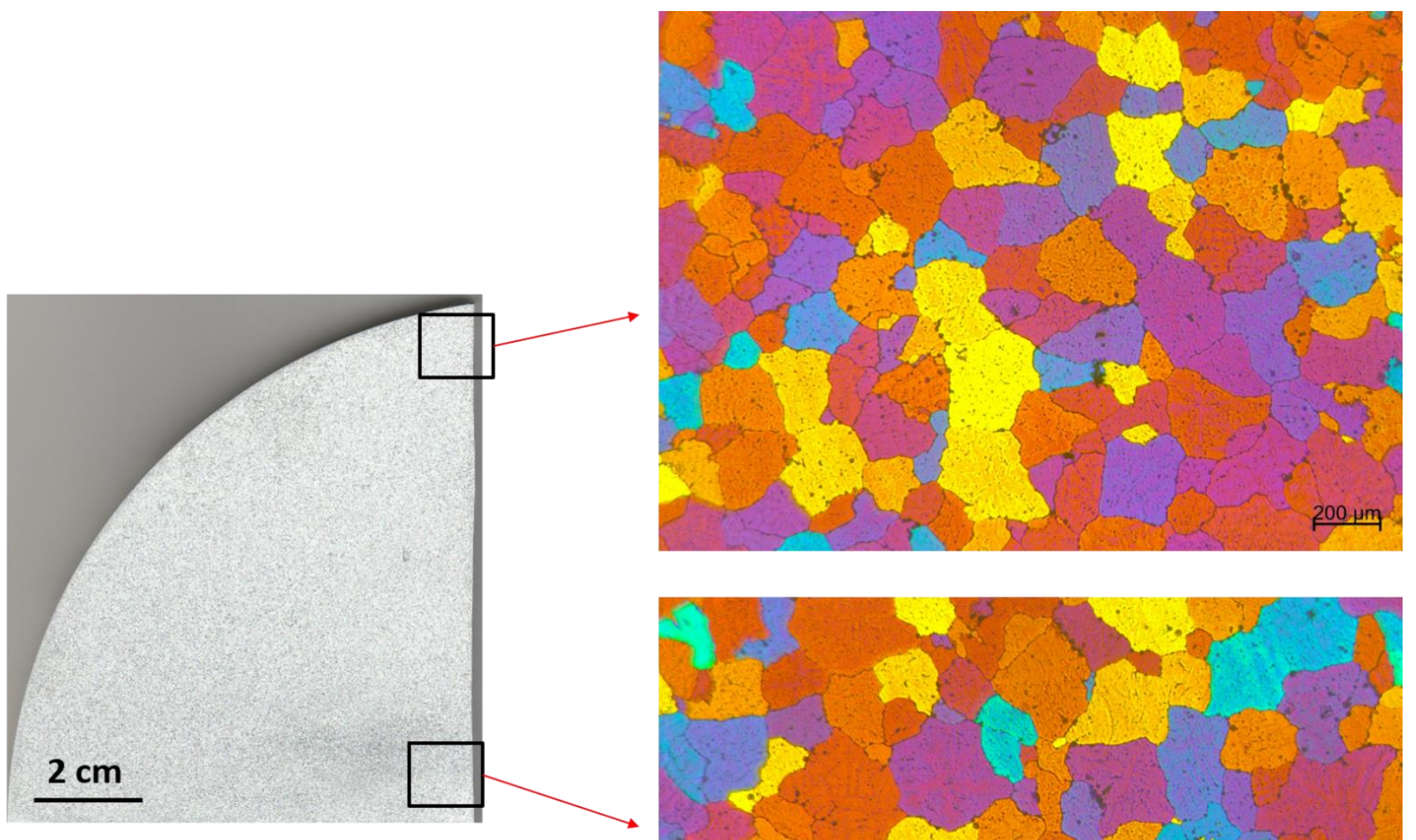

- $128,9 \pm 4,1 \mathrm{HV}$

- $40,5 \%$ IACS

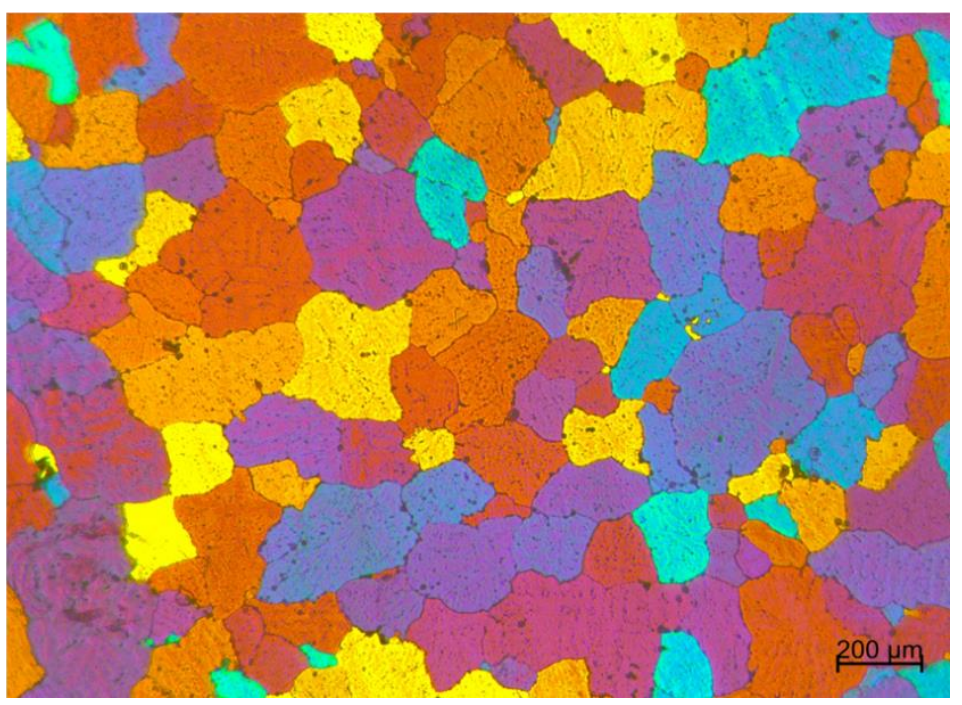

Figura 57 - Micrografias ópticas obtidas com auxílio de luz polarizada das amostras homogeneizadas. As setas relacionam a micografia com o local em que foram extraídas as amostras 
Em relação às medidas de dureza e condutividade elétrica, nota-se que o tratamento de homogeneização tornou a liga ligeiramente mais resistente e mais condutiva. A liga, oriunda do mesmo lote da utilizada por Gianiselle [11], foi homogeneizada a $486^{\circ} \mathrm{C}$ (temperatura elevada o suficiente para causar a solubilização de $M g Z n_{2}$ nas ligas de alumínio da série $7 \mathrm{XXX}$ [33]), conforme indicado pela Figura 58, e foi resfriada em água. No entanto, como se trata um produto de geometria industrial (tarugos de $200 \mathrm{~mm}$ de diâmetro), ocorre que o resfriamento pode não ter sido realizado com a rapidez necessária, de modo que a precipitação de intermetálicos fez-se possível, o que explica a elevação da dureza observada. A formação desses precipitados, por outro lado, retira elementos em solução sólida da matriz rica em alumínio e, dessa forma, reduz a condutividade elétrica do material.

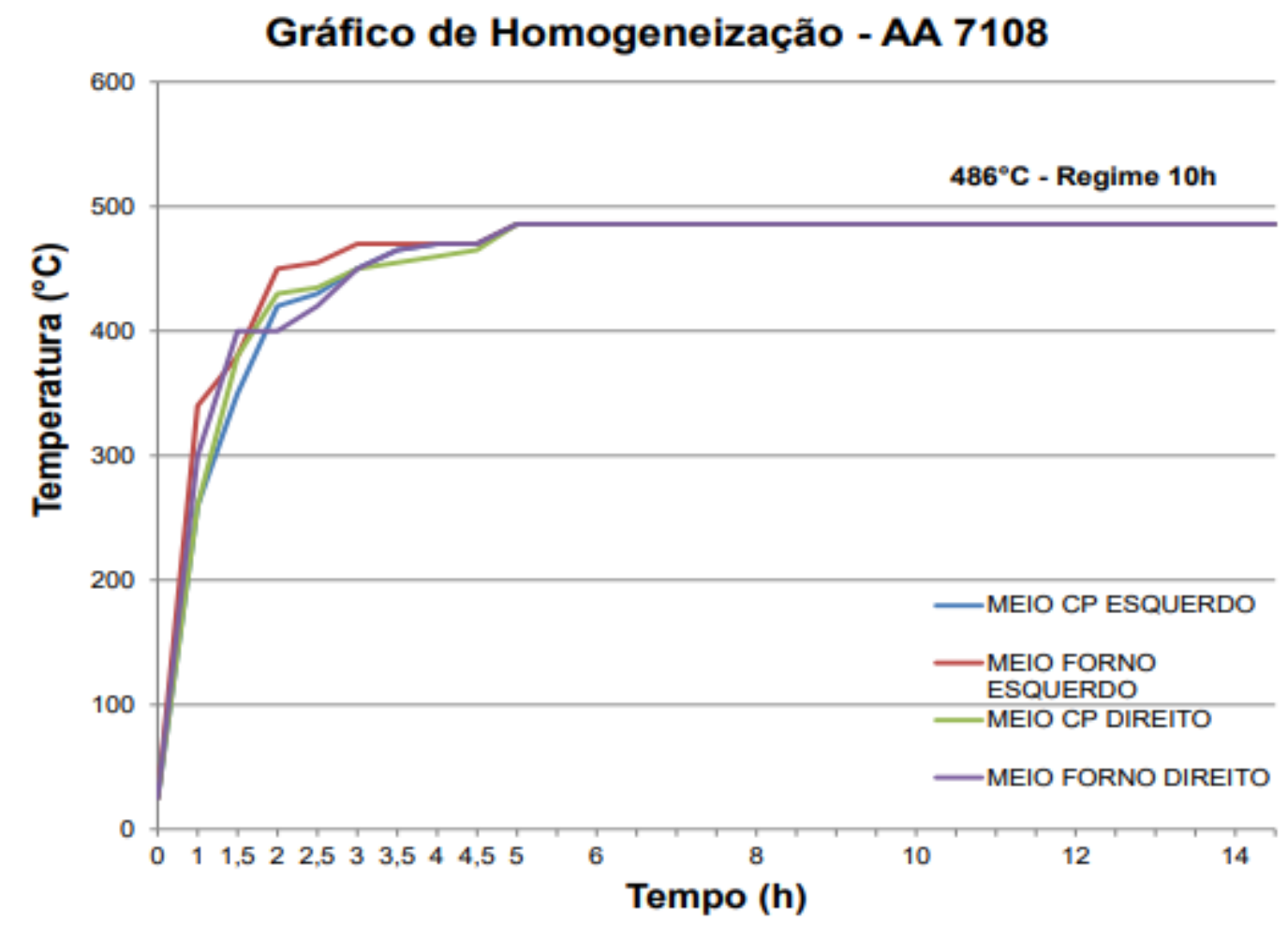

Figura 58 - Ciclo térmico adotado na CBA para realização do tratamento térmico de homogeneização [11]

As Figuras 59 e 60 mostram micrografias obtidas por microscopia eletrônica de varredura (modo elétrons secundários) da AA 7108 nos estados bruto de solidificação e homogeneizado, respectivamente. Ambas as amostras foram atacadas previamente com reagente de Tucker sob as mesmas condições. A diferença de aspecto entre as micrografias pode ser explicada com base no tratamento de homogeneização. $O$ material no estado bruto de solidificação possui microestrutura formada por dendritas 
que possuem composição química distinta em relação aos arredores. Tal diferença de composição é causada pelo fenômeno de microssegregação que promove a expulsão de elementos de liga durante a ocorrência da solidificação. Como regiões com maiores teores de elementos de liga (isso é, na região exterior às dendritas) tendem a ser preferencialmente atacadas pelos reagentes químicos, observa-se que a micrografia da amostra bruta de solidificação da Figura 59 apresenta a estrutura dendrítica bastante aparente, sendo que os arredores são removidos por ação química.

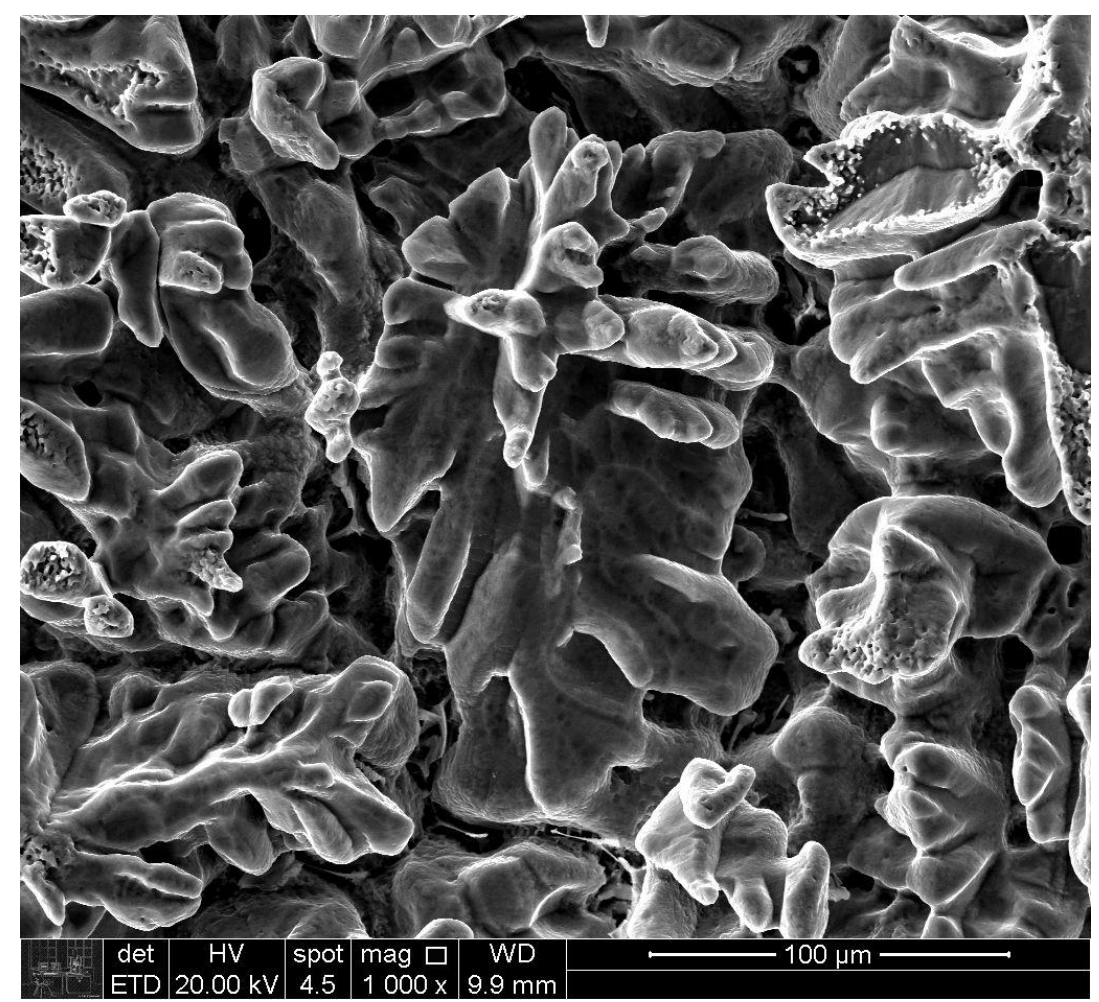

Figura 59 - Micrografia obtida por microscopia eletrônica de varredura (modo elétrons secundários) da amostra bruta de solidificação

Já em relação a amostra homogeneizada, os efeitos da microssegregação são atenuados, pois ocorre a redistribuição de soluto. Dessa forma, não ocorre remoção diferencial de material em função da diferença de composição e a microestrutura se revela com a estrutura dendrítica menos aparente, conforme mostrado na Figura 60. 


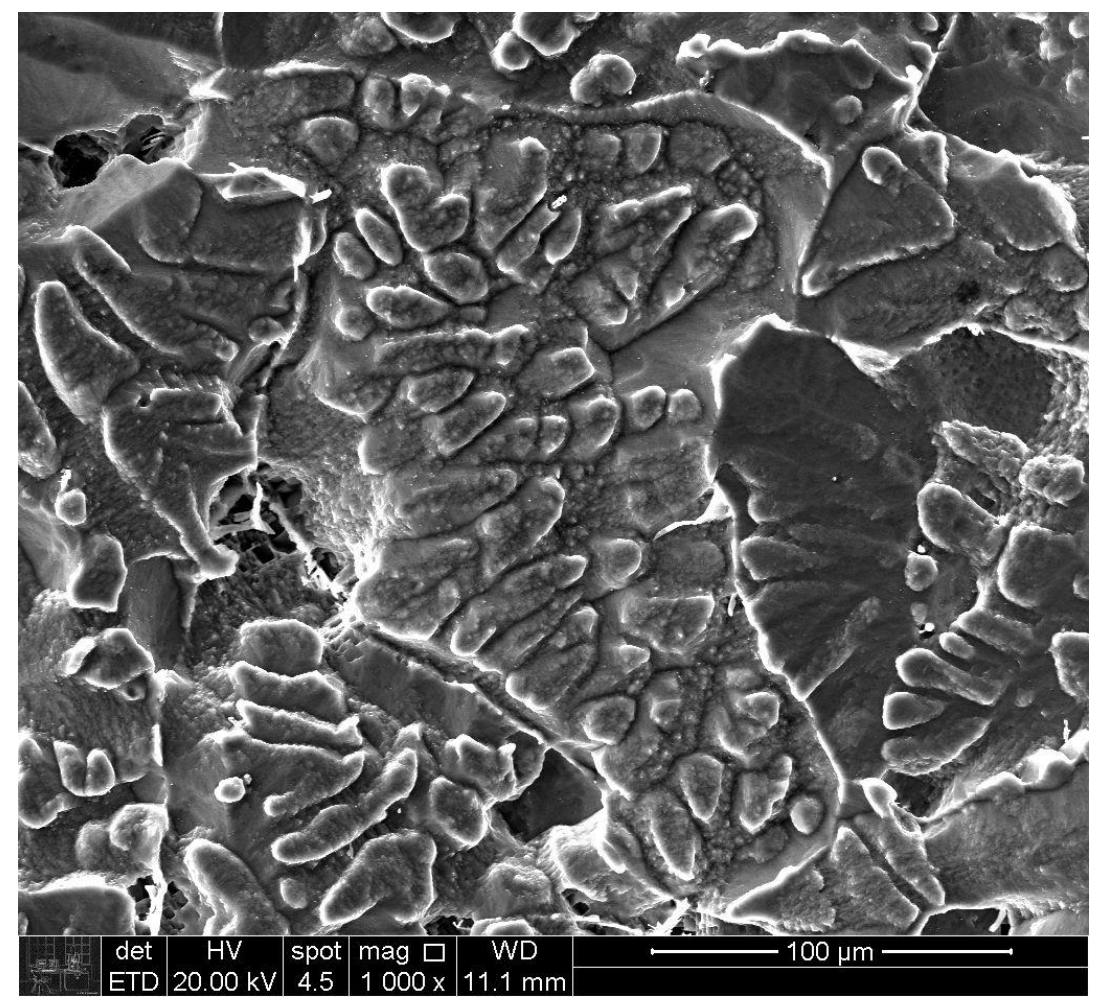

Figura 60 - Micrografia obtida por microscopia eletrônica de varredura (modo elétrons secundários) da amostra homogeneizada

As micrografias apresentadas anteriormente foram obtidas após ataque químico com reagente de Tucker. $O$ ataque promove a remoção das partículas de segunda fase, de modo que a análise das fases metálicas, incluindo as interdendríticas, é impedida.

A Figura 61 mostra uma micrografia obtida por microscopia eletrônica de varredura (no modo elétrons retroespalhados) da amostra da AA 7108 no estado bruto de solidificação e sem ataque. É possível observar a presença de intermetálicos interdendríticos, além do efeito da microssegregação de átomos de soluto. Esse último é evidenciado por tons mais claros presentes em algumas regiões, reflexo da concentração de átomos de soluto de maior peso atômico nesses locais. 


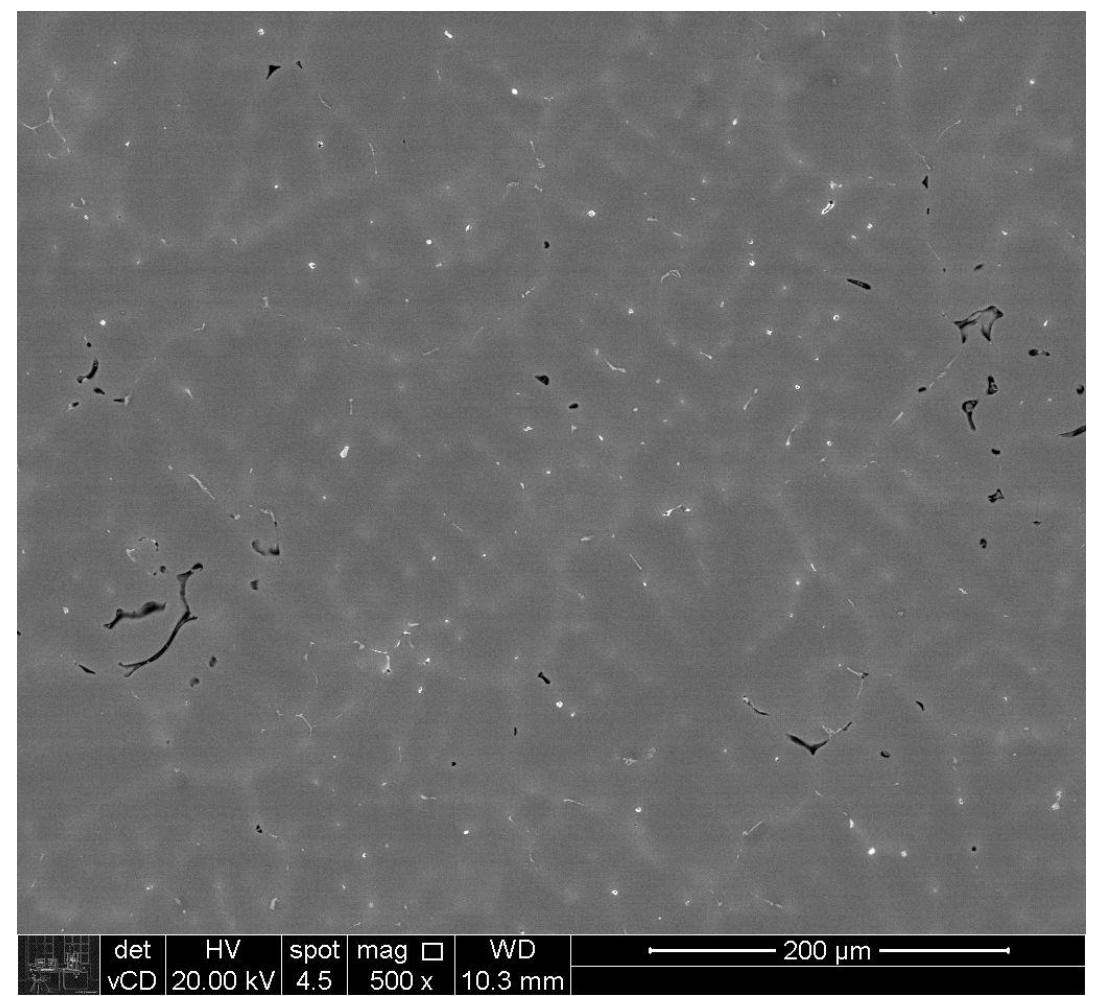

Figura 61 - Micrografia obtida por microscopia eletrônica de varredura (modo elétrons retroespalhados) da amostra bruta de solidificação. É possível notar a presença de fases intedendríticas assim como o fenômeno de microssegregação

A Figura 62 exibe outra micrografia obtida por microscopia eletrônica de varredura (no modo elétrons retroespalhados) da amostra da AA 7108 no estado bruto de solidificação e sem ataque. Nesse caso, também estão mostradas as composições de determinadas regiões e pontos adquiridos a partir de espectroscopia de energia dispersiva (EDS). Com relação a análise da área (matriz), nota-se a predominância do zinco e do magnésio juntamente com o alumínio, o esperado para uma liga de alumínio que possui $\mathrm{Zn}$ e Mg como elementos principais e que apresentam boa solubilidade no Al [22]. Além disso, observa-se a presença de um dispersoide com elevado teor de Fe e de uma fase formada por altos teores de $\mathrm{Zn}$ e $\mathrm{Mg}$, possivelmente MgZn ou MgZn2, fases previstas nos diagramas de equilíbrio Al-Zn-Mg (vide Figura 11). 


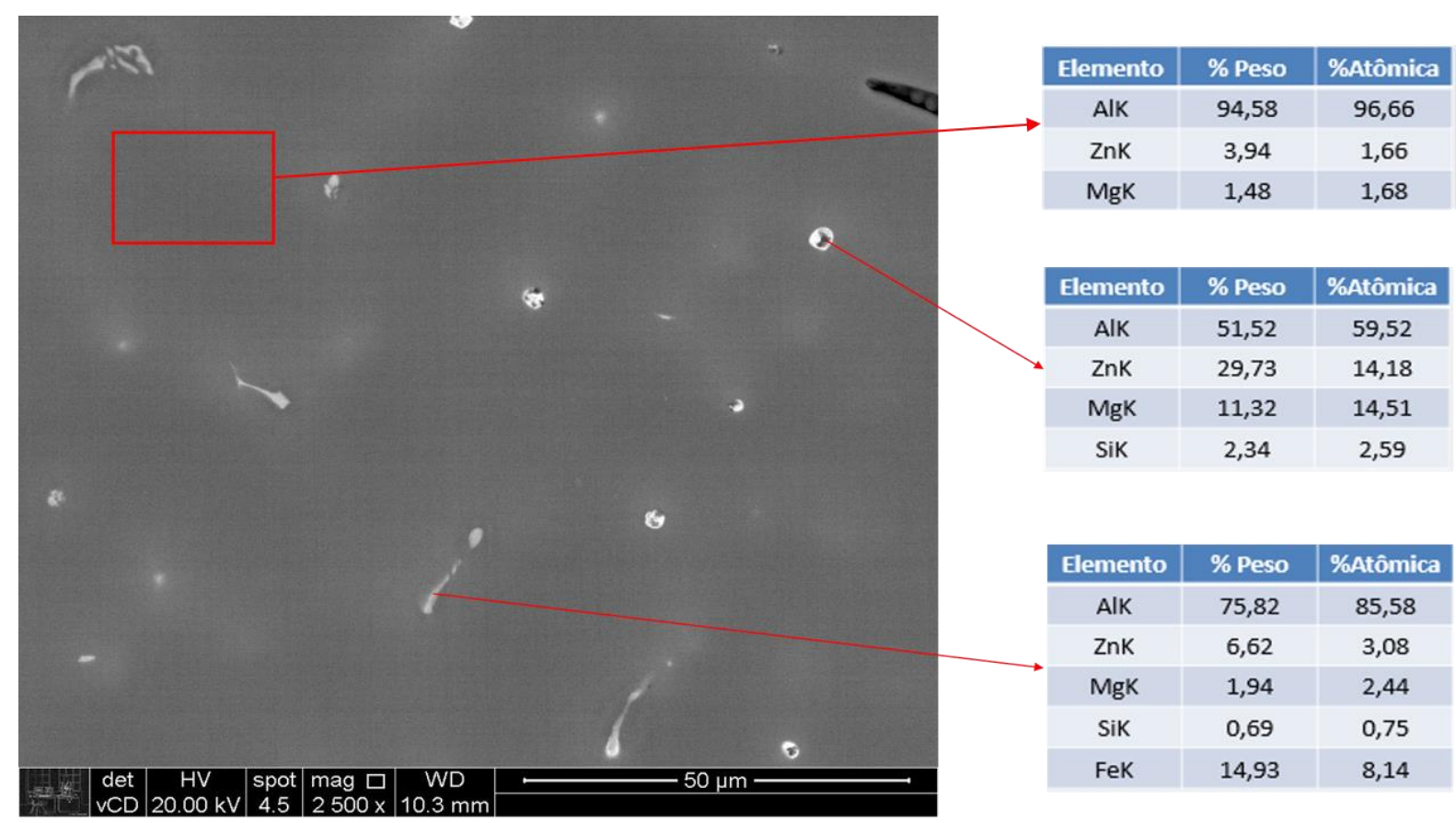

Figura 62 - Micrografia obtida por microscopia eletrônica de varredura (modo elétrons retroespalhados) da amostra bruta de solidificação. As setas indicam regiões e pontos analisados via EDS e as respectivas composições químicas associadas

Além desses intermetálicos, foram encontradas numerosas partículas de segunda fase, com aspecto facetado, cuja composição química foi medida via espectroscopia de energia dispersiva (EDS). A Figura 63 exibe o aspecto e a composição obtida para a fase em questão presente na amostra bruta de solidificação, novamente sem ataque. É possível que tal precipitado seja o dispersóide $\mathrm{Al}_{3}(\mathrm{Zr}, \mathrm{Ti})$ cuja presença já foi reportada em outros estudos da AA 7108 [119]. As análises realizadas que serão apresentadas nas próximas seções (em especial a difração de raios $\mathrm{X}$ ) corroboram com essa possibilidade. 


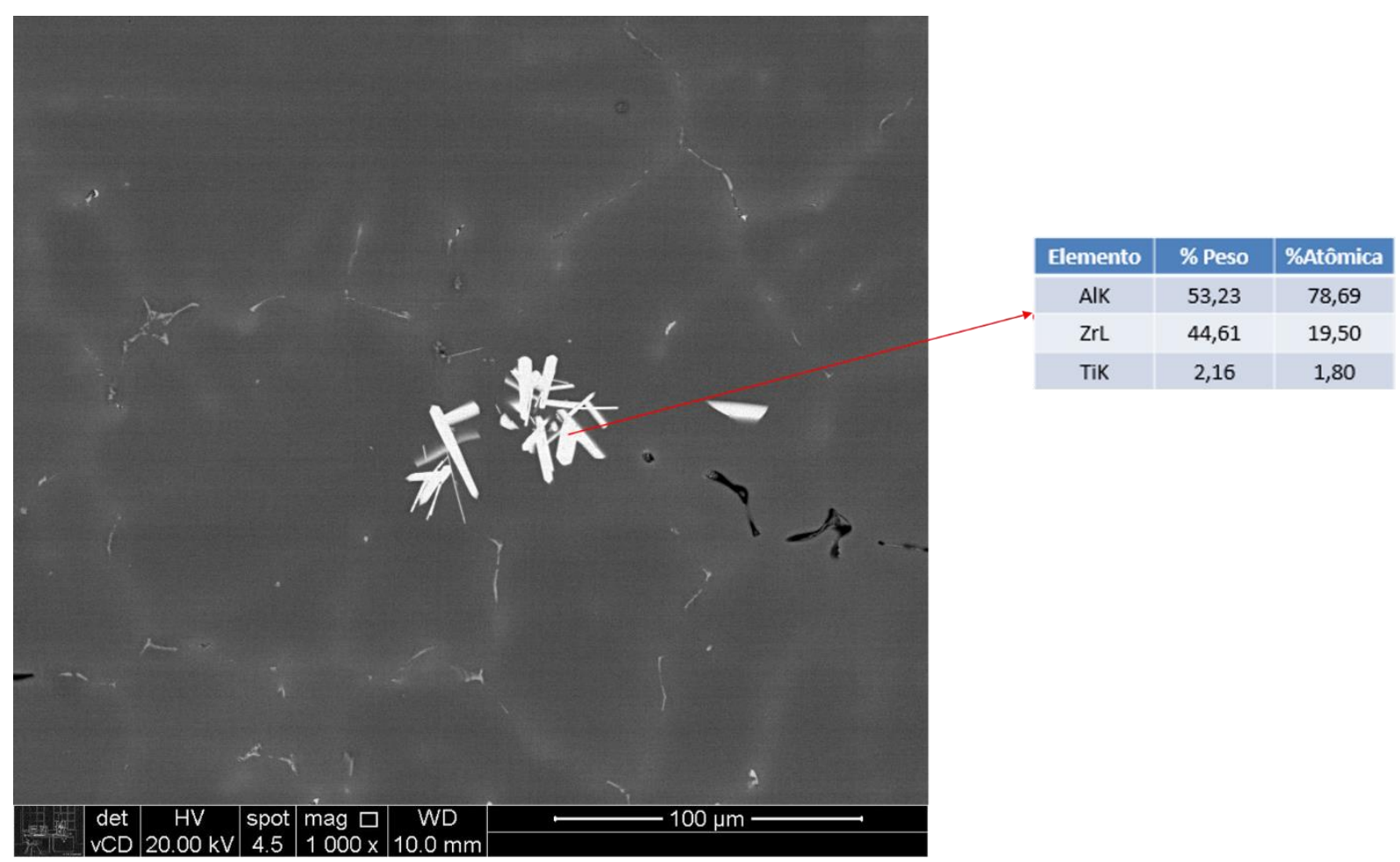

Figura 63 - Micrografia obtida por microscopia eletrônica de varredura (modo elétrons retroespalhados) da amostra bruta de solidificação. As setas indicam regiões e pontos analisados via EDS e as respectivas composições químicas associadas

A Figura 64 mostra uma micrografia obtida por microscopia eletrônica de varredura (no modo elétrons retroespalhados) da amostra da AA 7108 no estado homogeneizado e sem ataque. Observa-se que o efeito da microssegregação não se faz presente (compare com a Figura 63) e que o volume de precipitados é menor em relação à amostra bruta de solidificação. Tais observações indicam o sucesso associado ao tratamento térmico de homogeneização. 


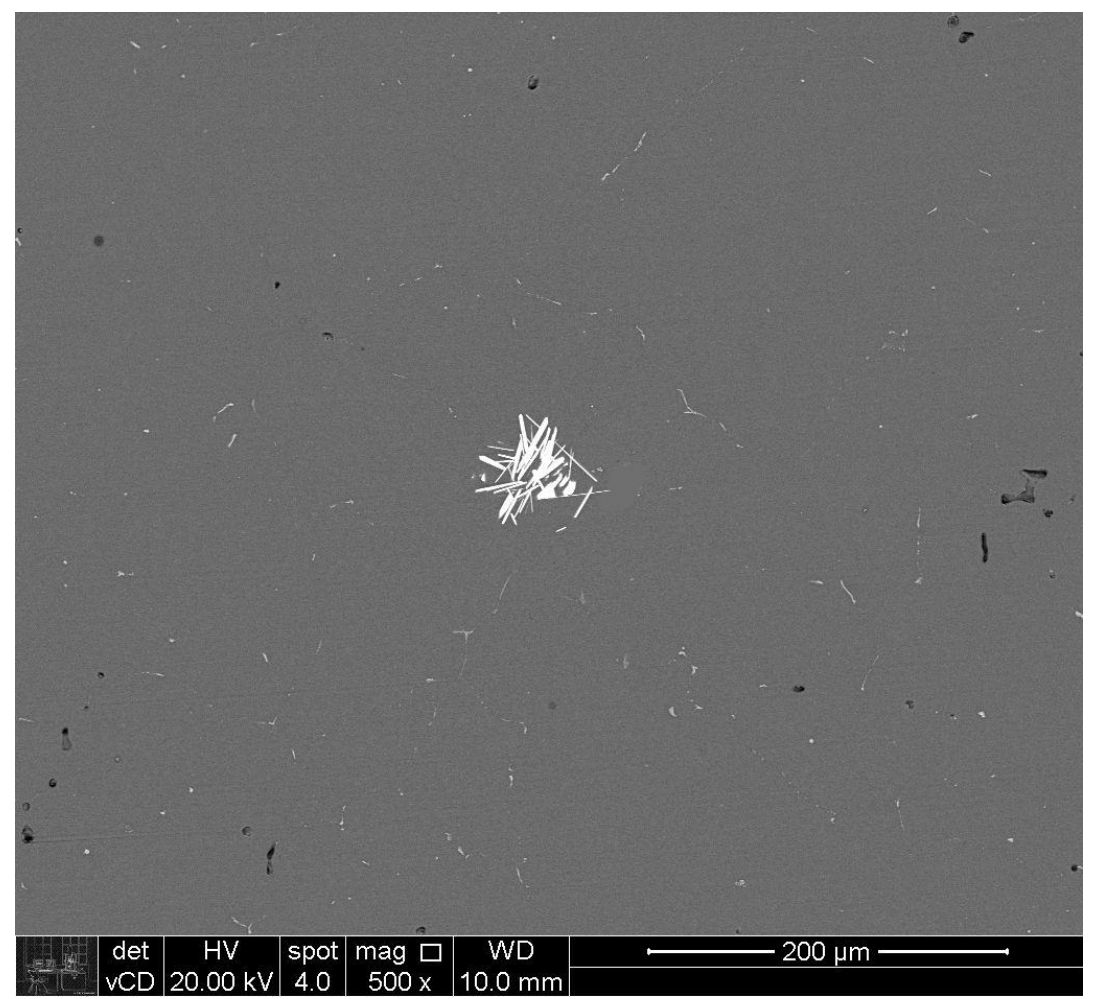

Figura 64 - Micrografia obtida por microscopia eletrônica de varredura (modo elétrons retroespalhados) da amostra homogeneizada. Observa-se uma atenuação do fenômeno de microssegregação. Nota-se também a diminuição da concentração de intermetálicos, indicando que houve solubilização de algumas dessas fases

Adicionalmente, não foram encontrados precipitados com elevados teores de $\mathrm{Zn}$ e Mg, como havia sido observado nas amostras homogeneizadas. A Figura 65 exibe uma micrografia obtida por microscopia eletrônica de varredura (no modo elétrons retroespalhados) juntamente com a composição determinada via EDS associada a determinados pontos e áreas. Com relação a matriz rica em Al, observa-se pouca variação em relação à amostra bruta de solidificação. Dispersoides com elevados teores de Fe são observados, uma vez que os tratamentos térmicos não promovem a dissolução dessas fases [120]. O dispersoide rico em Zr e Ti também foi identificado nas amostras homogeneizadas. 


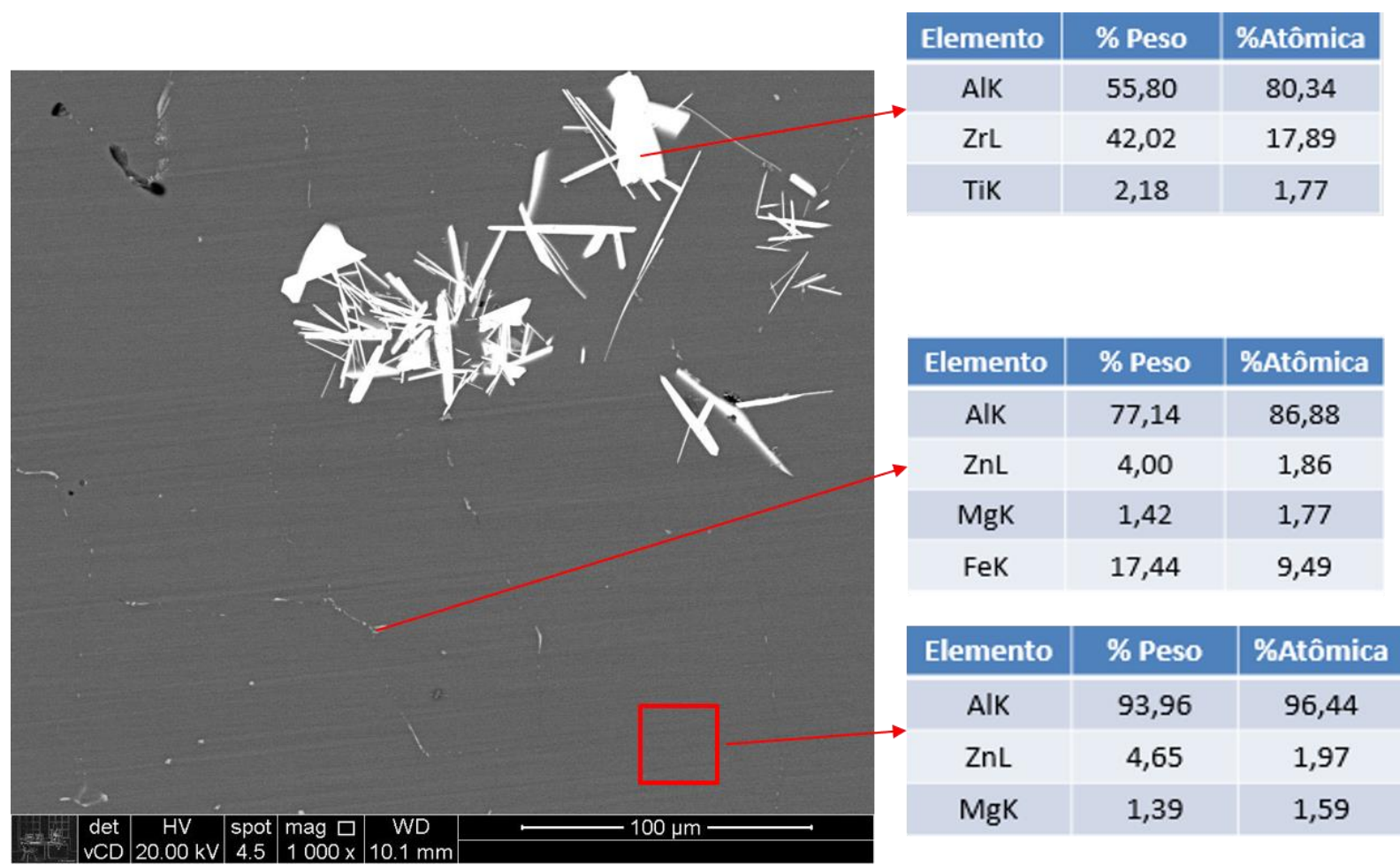

Figura 65- Micrografia obtida por microscopia eletrônica de varredura (modo elétrons retroespalhados) da amostra homogeneizada. As setas indicam regiões e pontos analisados via EDS e as respectivas composições químicas associadas

A Figura 66 exibe os difratogramas relativos às amostras bruta de solidificação e homogeneizada. Na escala em que são apresentados, é possível notar apenas os intensos picos associados à matriz rica em alumínio. A diferença na intensidade relativa entre os picos associados às distintas famílias de planos cristalográficos indica, em primeira análise, alteração da textura cristalográfica, possivelmente em função do crescimento de grão ocorrido durante a homogeneização. Diferenças em relação a picos relativos a outras fases podem ser notados com uso de maiores ampliações dos difratogramas, como será mostrado a seguir. 

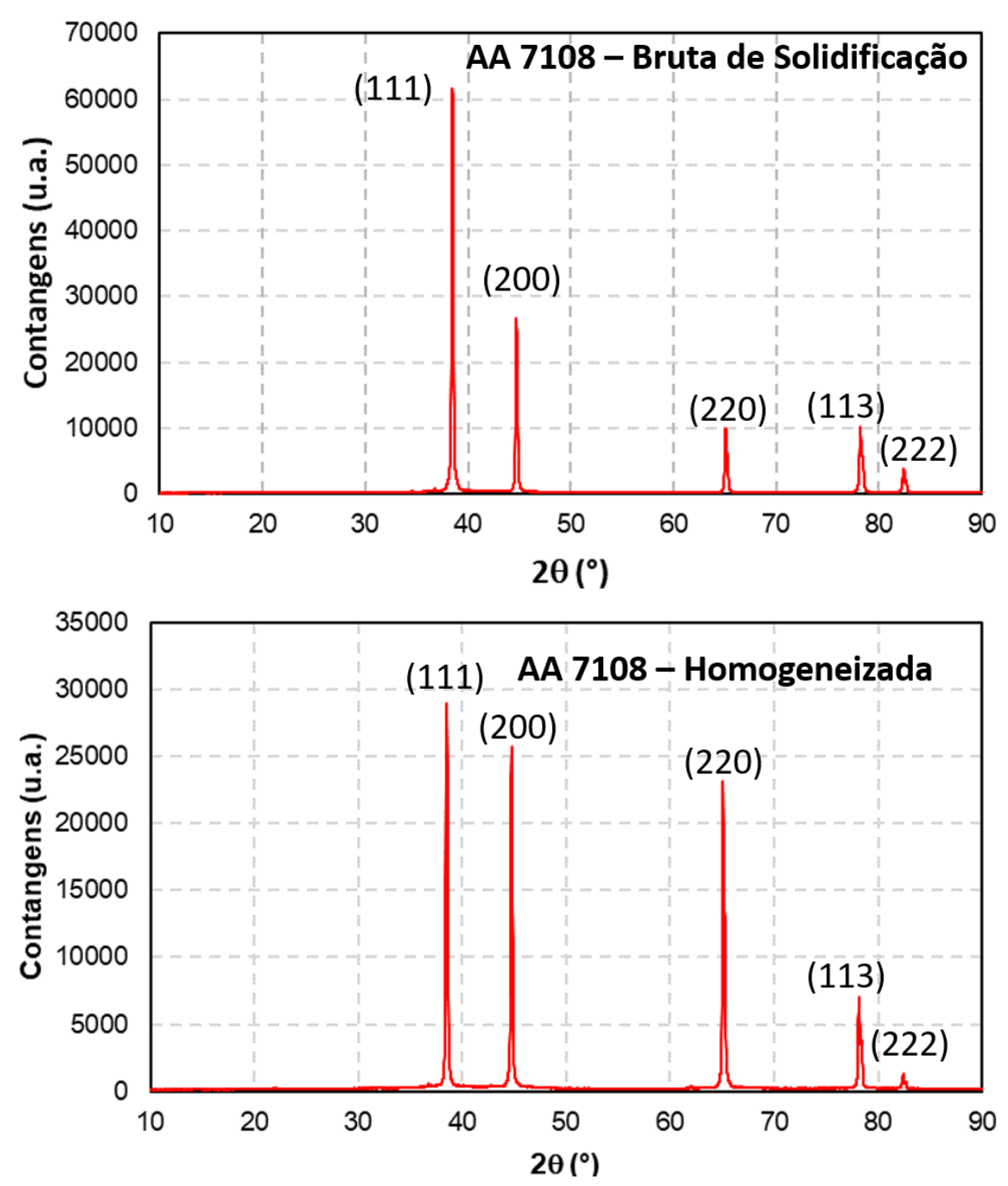

Figura 66 - Difratograma da AA 7108 nos estados bruto de solidificação e homogeneizado. São indicadas as famílias de planos relativas ao alumínio em cada um dos dois estados avaliados

A análise do difratograma em outras escalas permite a identificação de picos associados à fase $\mathrm{Mg}_{0,97} \mathrm{Zn}_{0,03}$, conforme indicado na Figura 67. Esse intermetálico, identificado com auxílio da ficha ICSD 98-007-4849, é uma fase hexagonal constituída de dois elementos químicos ( $\mathrm{Mg}$ e $\mathrm{Zn}$ ) relativamente solúveis no alumínio (vide Tabela 1). Dessa forma, mediante o tratamento térmico adequado, ocorre a solubilização desse intermetálico na matriz rica em alumínio. No entanto, a quantificação da solubilização dessa fase não pode ser quantificada simplesmente pela diminuição da altura relativa dos picos a ela associados. Tal constatação pode ser feita somente com cuidadoso trabalho executado por microscopia eletrônica de transmissão de alta resolução. 

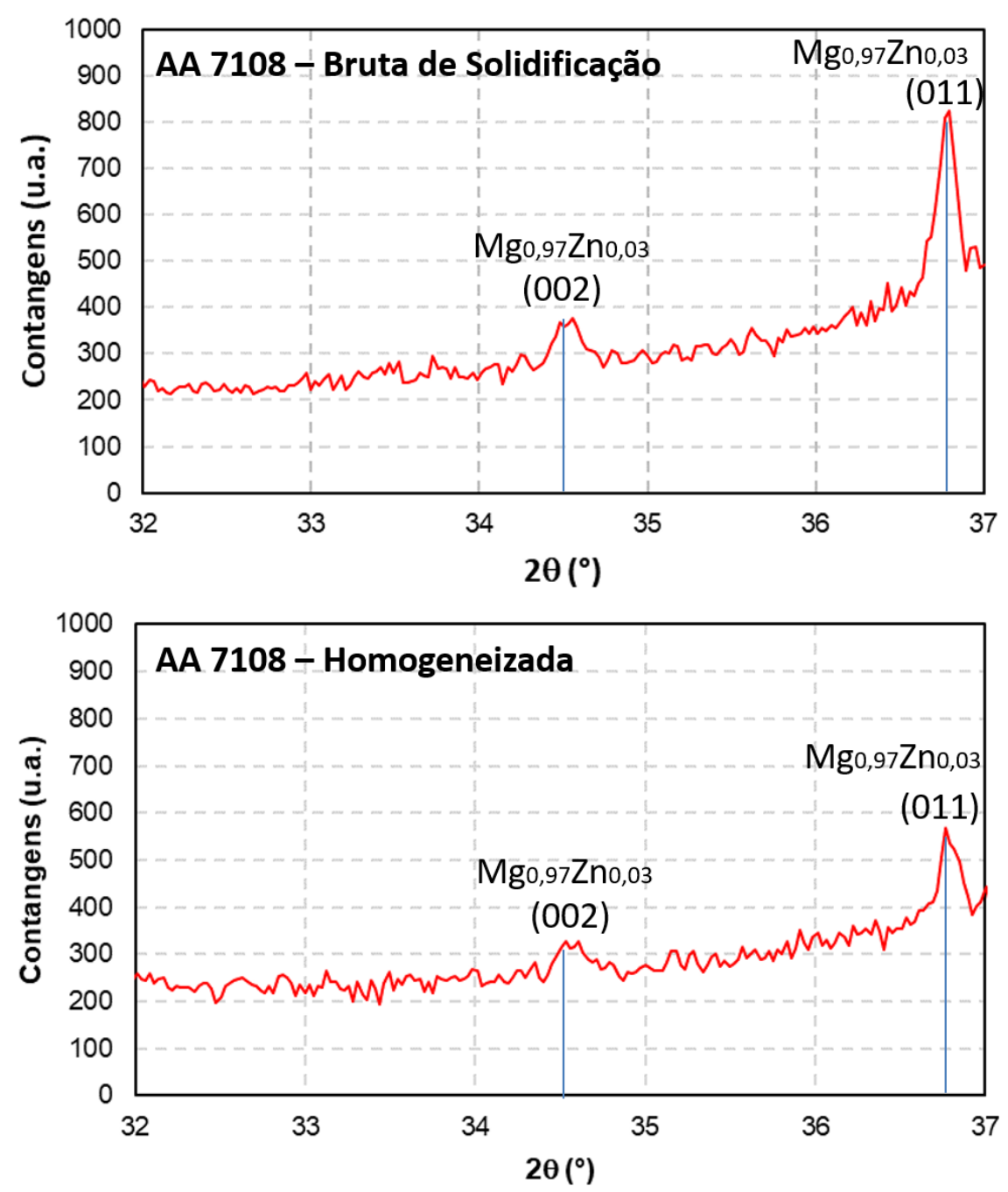

Figura 67 - Difratograma da AA 7108 nos estados bruto de solidificação e homogeneizado. São indicadas as famílias de planos relativas à fase $\mathrm{Mg}_{0,97} \mathrm{Zn}_{0,03}$.

A respeito dos dipersoides com elevado teor de $\mathrm{Ti}$, não foi possível a identificação inequívoca dessa fase com base nos difratogramas das amostras brutas de solidificação e homogeneizada. Isso porque, o pico passível de ser associado ao $\mathrm{Al}_{3} \mathrm{Ti}$ (indicado pelo "asterisco" na Figura 68 ) encontra-se em um ângulo $2 \theta$ próximo do pico (de maior intensidade) relativo à família de planos (033) da fase $\mathrm{Fe}_{4} \mathrm{Zn}_{9}$. Dessa forma, é possível que os picos de ambas as fases se sobreponham no mencionado intervalo. Posteriormente (vide Figura 74), a identificação da fase $\mathrm{Al}_{3} \mathrm{Ti}$ será possível pela análise de picos associados a outros ângulos. Adicionalmente, é possível afirmar que a pequena fração volumétrica dos dispersoides presentes na AA 7108 utilizadas nesse estudo dificulta a sua identificação. 

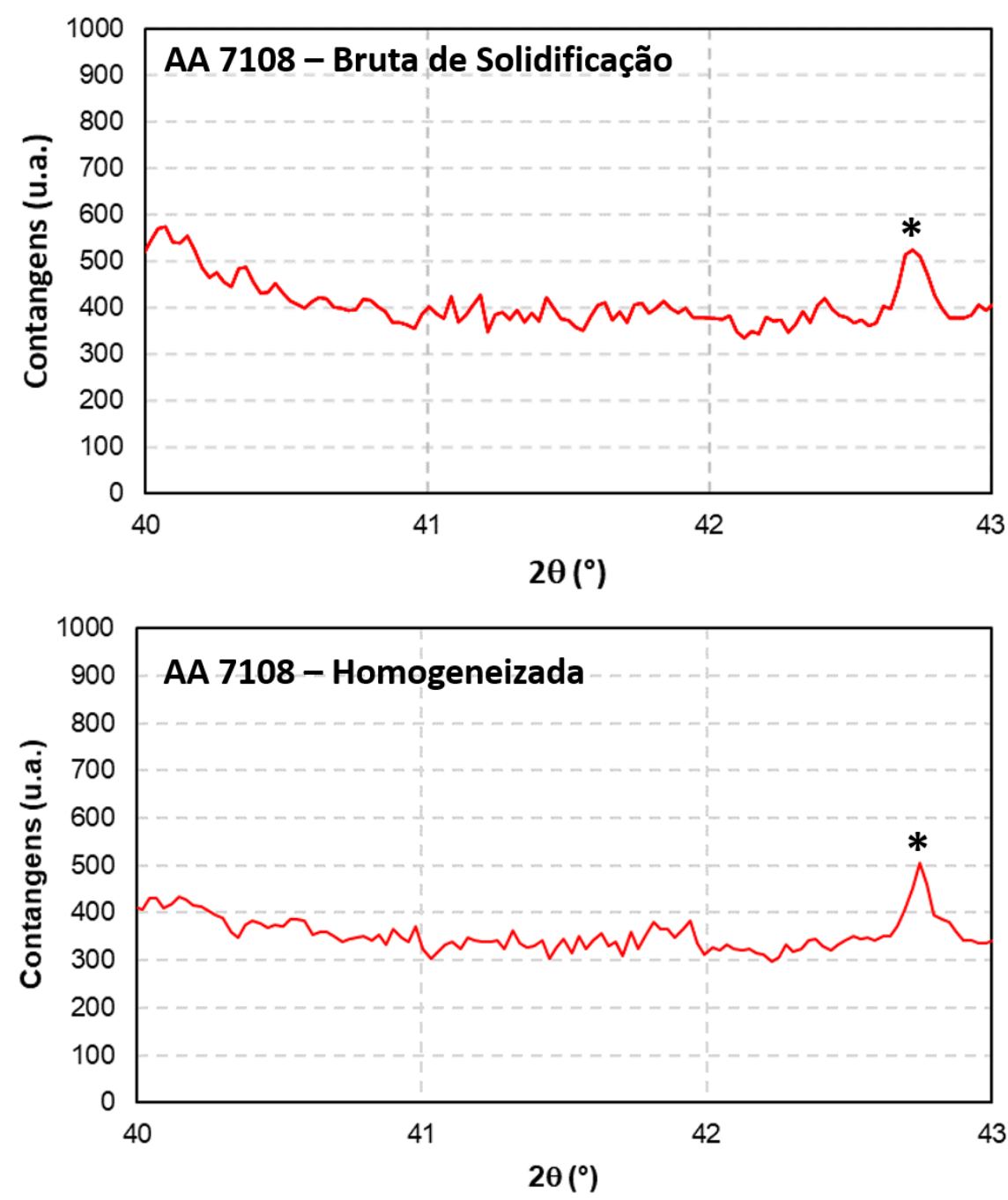

Figura 68 - Difratograma da AA 7108 nos estados bruto de solidificação e homogeneizado. O "asterisco" indica um pico que não pode ser inequivocadamente identificado, já que esse está compreendido em um intervalo de ângulos em que tanto picos de $\mathrm{Al}_{3} \mathrm{Ti}$ quanto de $\mathrm{Fe}_{4} \mathrm{Zn}_{9}$ fazem-se presentes

Utilizando-se os dados experimentais de difratometria é possível estimar com elevada precisão o parâmetro de rede associado à matriz rica em alumínio. Inicialmente, calcula-se o valor da distância interplanar (d) associada a cada família de planos cristalográficos que promovem a difração da radiação incidente. Para tal, utiliza-se a Lei de Bragg na forma:

$$
d=\frac{\lambda}{2 \operatorname{sen} \theta}
$$

Onde " $\lambda$ " corresponde ao comprimento de onda da radiação $\mathrm{Cu}$-Ka e " $\theta$ " é a metade do valor do ângulo de difração $(2 \theta)$ obtido experimentalmente. 
A seguir, com os valores de distância interplanar, é possível estimar o valor do parâmetro de rede (a) por meio de:

$$
a=d \sqrt{h^{2}+k^{2}+l^{2}}
$$

Onde "h"," k" e "l" correspondem aos respectivos índices de Miller da família de planos cristalográficos associadas ao fenômeno de difração. Assim, ao se plotar os valores de "a" em função do parâmetro $\frac{\cos ^{2} \theta}{\operatorname{sen} \theta}$ [121], obtém-se os gráficos apresentados na Figura 69. Ajustando-se os dados pelo método dos mínimos quadrados, nota-se que em ambos os casos há boa correlação entre os valores experimentais e o modelo matemático aplicado. Isso pode ser comprovado pelo elevado valor do coeficiente de correlação $\left(R^{2}\right)$ obtido em ambos os casos.

Por fim, a equação da reta que melhor representa os pontos experimentais fornece o valor do parâmetro de rede associado à matriz rica em Al: basta observar o valor em que a reta em questão cruza o eixo das ordenadas, ou seja, o termo independente da equação da reta. $\mathrm{Na}$ análise em questão, observa-se que o valor do parâmetro de rede calculado para a amostra homogeneizada $(0,4057 \mathrm{~nm})$ é superior àquele relativo à amostra bruta de solidificação $(0,4055 \mathrm{~nm})$. O resultado é condizente com o processo de solubilização de intermetálicos, uma vez que o aumento do número de átomos em solução sólida tende a distorcer a rede cristalina da espécie que majoritariamente compõe a matriz de modo a aumentar o parâmetro de rede. 

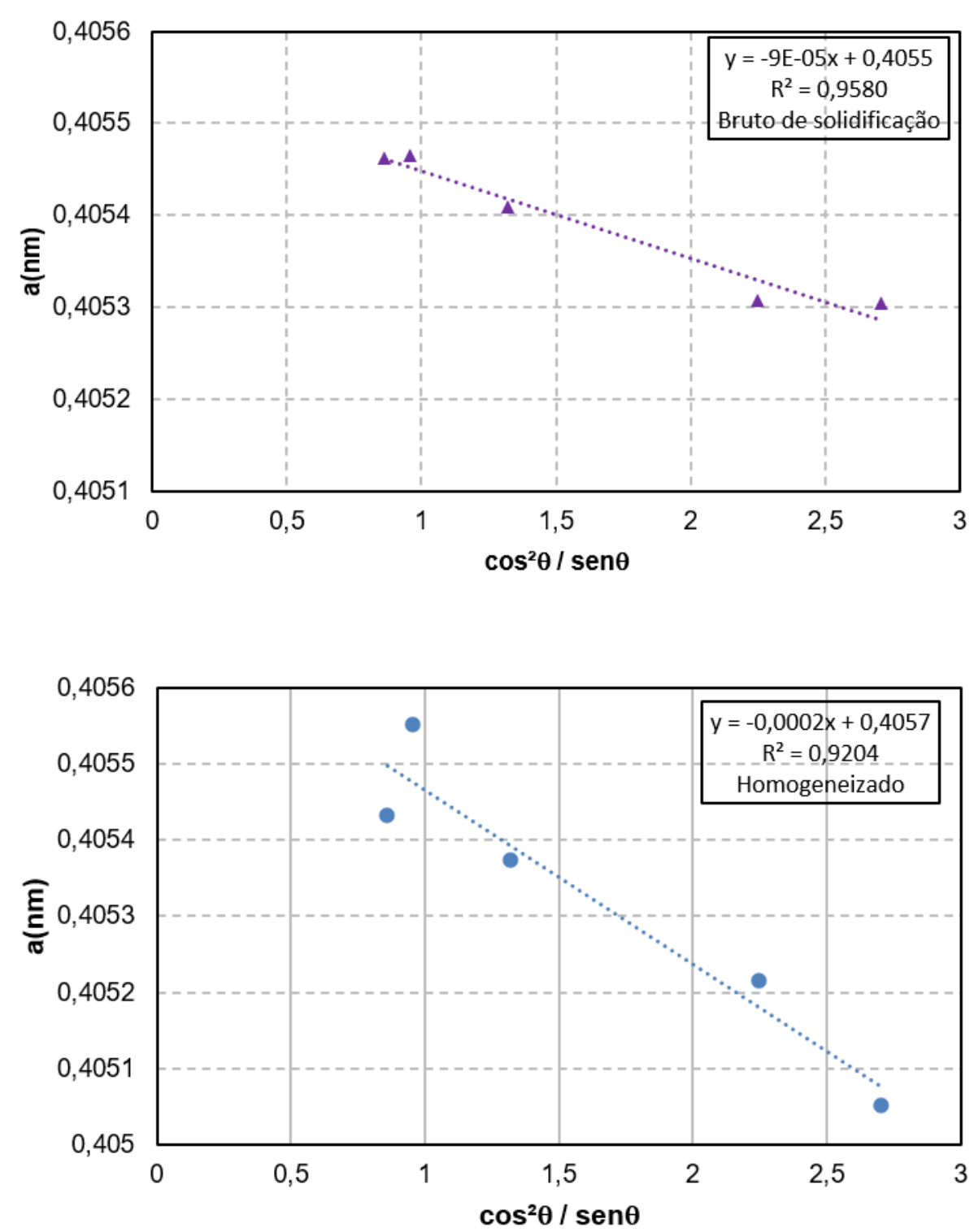

Figura 69 - Gráficos de "a" x " $\cos ^{2} \theta / \operatorname{sen} \theta$ " para as amostras nos estados bruto de solidificação e homogeneizado. A reta indicada em cada um dos gráficos foi obtida por meio do método dos mínimos quadrados e representa a melhor equação que representa o conjunto de dados experimentais indicados pelos pontos

\subsection{Caracterização microestrutural, medição de dureza Vickers e obtenção da macro e microtextura cristalográfica das amostras extrudadas}

\subsubsection{Microscopia óptica de luz polarizada}

A Figura 70 mostra micrografias obtidas por microscopia óptica de luz polarizada da AA 7108 no estado extrudada. São mostradas as direções de conformação (DL), normais à direção de conformação (DN) e transversais à direção de conformação (DT). 

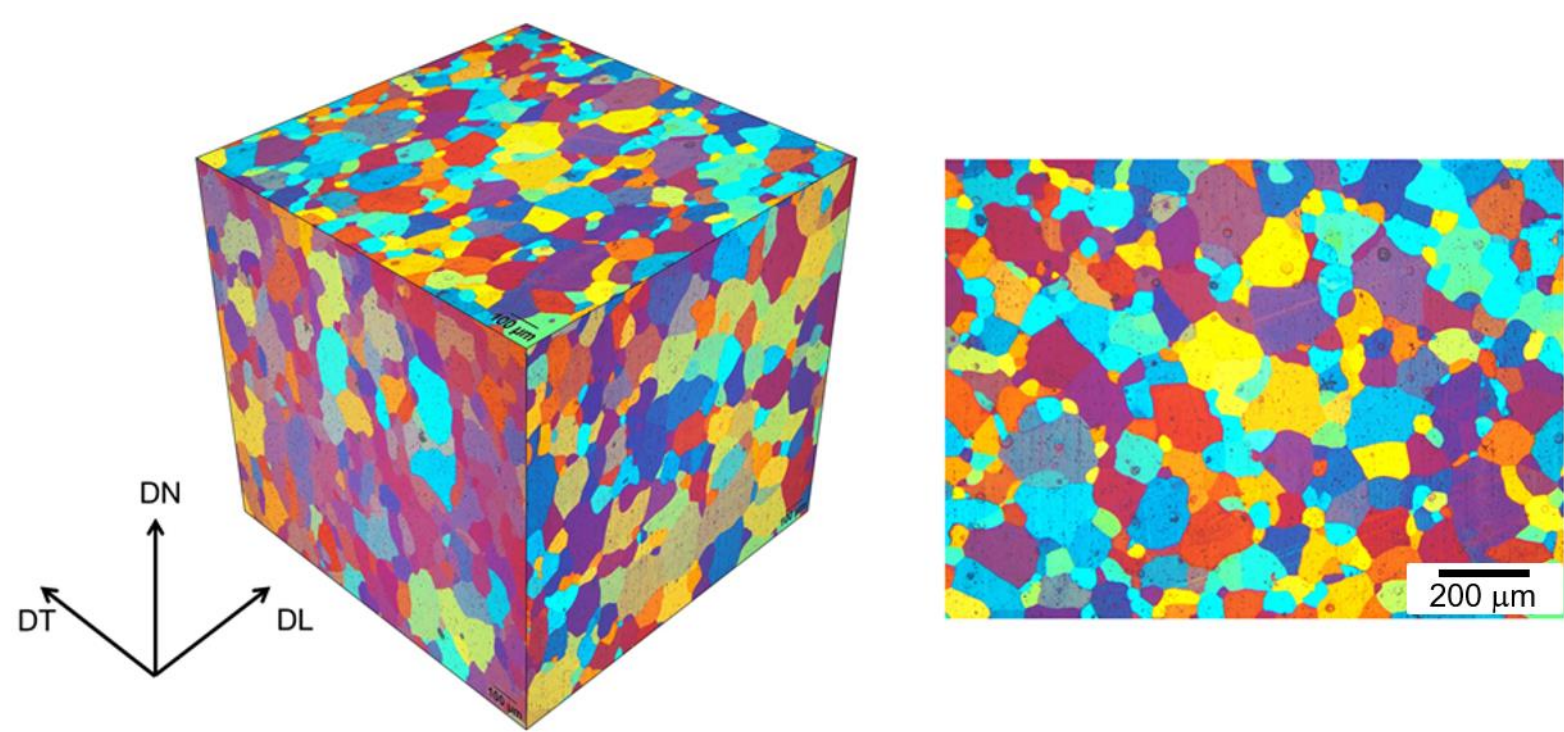

Figura 70 - Micrografias ópticas obtidas com auxílio de luz polarizada da amostra extrudada. DT representa a direção transversal, DL representa a direção de laminação e DN representa a direção normal em relação ao processo de extrusão. A micrografia à direita representa a superfície de extrusão SE

Observa-se uma estrutura de grãos refinados aproximadamente equiaxiais nas três superfícies analisadas. A origem de tal microestrutura é atribuída ao processamento termomecânico a qual a barra foi submetida (extrusão a quente), o que promoveu o fenômeno de recristalização dinâmica (ou metadinâmica) e resultou na estrutura de grãos mencionada. Isso porque o processo de extrusão envolve tanto elevadas temperaturas, quanto elevados graus e taxas de deformação, fatores esses que tendem a promover a ocorrência de recristalização durante a deformação (dinâmica) ou logo após a deformação (metadinâmica) [94].

A análise da microestrutura das bordas da seção transversal da AA 7108 difere daquela observada em regiões próximas ao centro da barra. É possível notar que os grãos mais próximos à matriz de extrusão são bastante refinados em relação aos grãos grosseiros da região adjacente. Tal fenômeno, descrito na literatura como PCGZ, é frequentemente observado em estudos com ligas de alumínio extrudadas a quente [1,100]. Sabe-se que a combinação entre elevada deformação e atrito, existente na região do material próxima da ferramenta de extrusão, pode contribuir com a ocorrência de PCGZ [100]. A Figura 71 mostra as micrografias das bordas e da região central da seção transversal da AA 7108 extrudada. É possível observar a mencionada zona presente nas bordas da amostra e adjacente a grãos finos que vão 
crescendo na medida em que se dirige para o centro da barra, mas sem atingir a dimensão daqueles localizados nas bordas

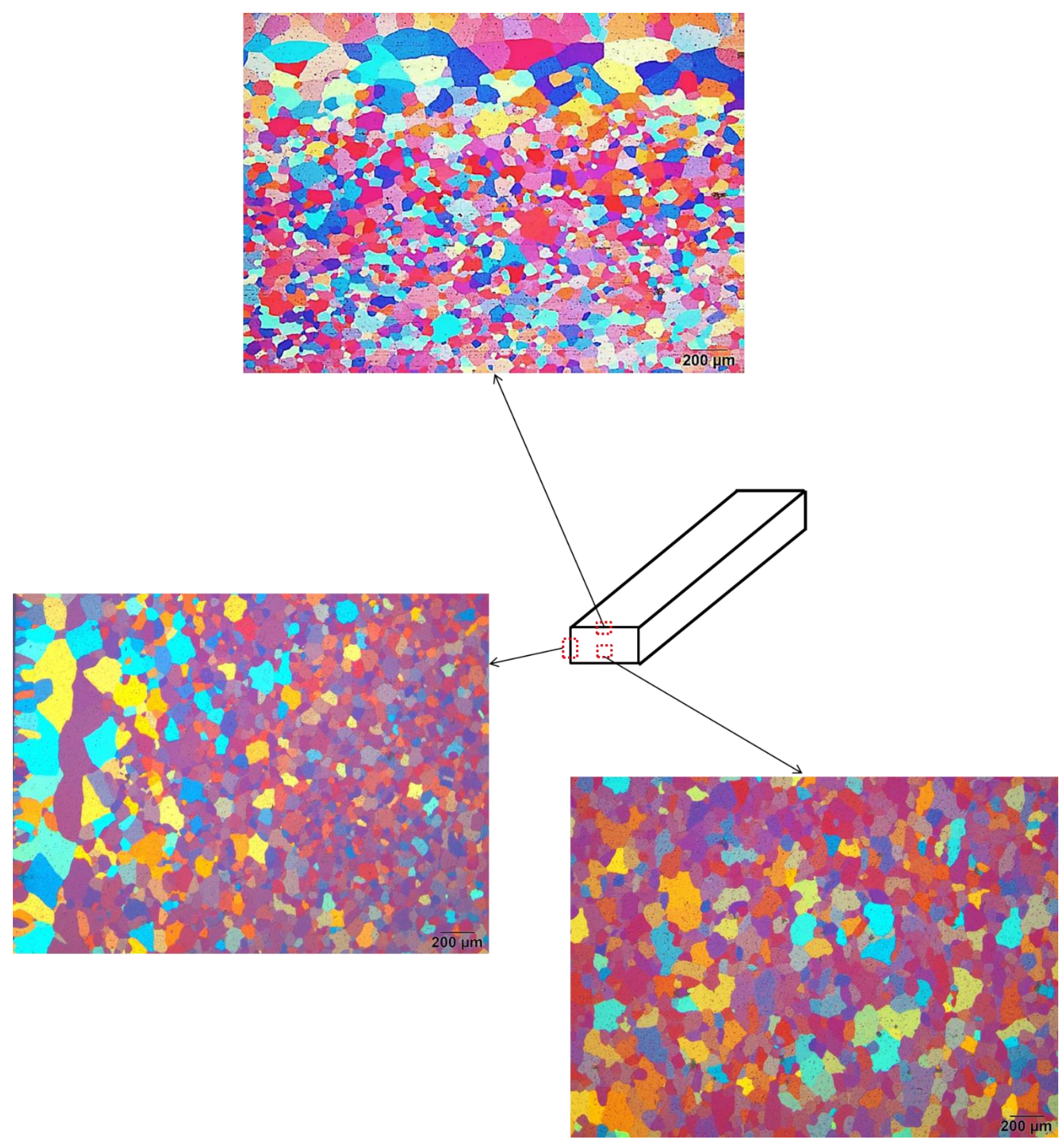

Figura 71 - Micrografias ópticas obtidas com auxílio de luz polarizada para a seção tranversal da amostra extrudada. As imagens indicam a diferença entre o tamanho médio dos grãos do centro e os da periferia.

\subsubsection{Microscopia eletrônica de varredura, EDS e DRX}

A Figura 72 mostra uma micrografia da AA 7108 obtida por microscopia eletrônica de varredura no modo elétrons retroespalhados. Foram encontradas 
partículas de segunda fase, de aspecto facetado, cuja composição química foi medida via espectroscopia de energia dispersiva (EDS). O resultado das análises pontuais também está indicado na Figura 72. Tal precipitado, presente nas etapas anteriores de processamento (Vide Figura 65), corresponde ao $\mathrm{Al}_{3}(\mathrm{Zr}, \mathrm{Ti})$.

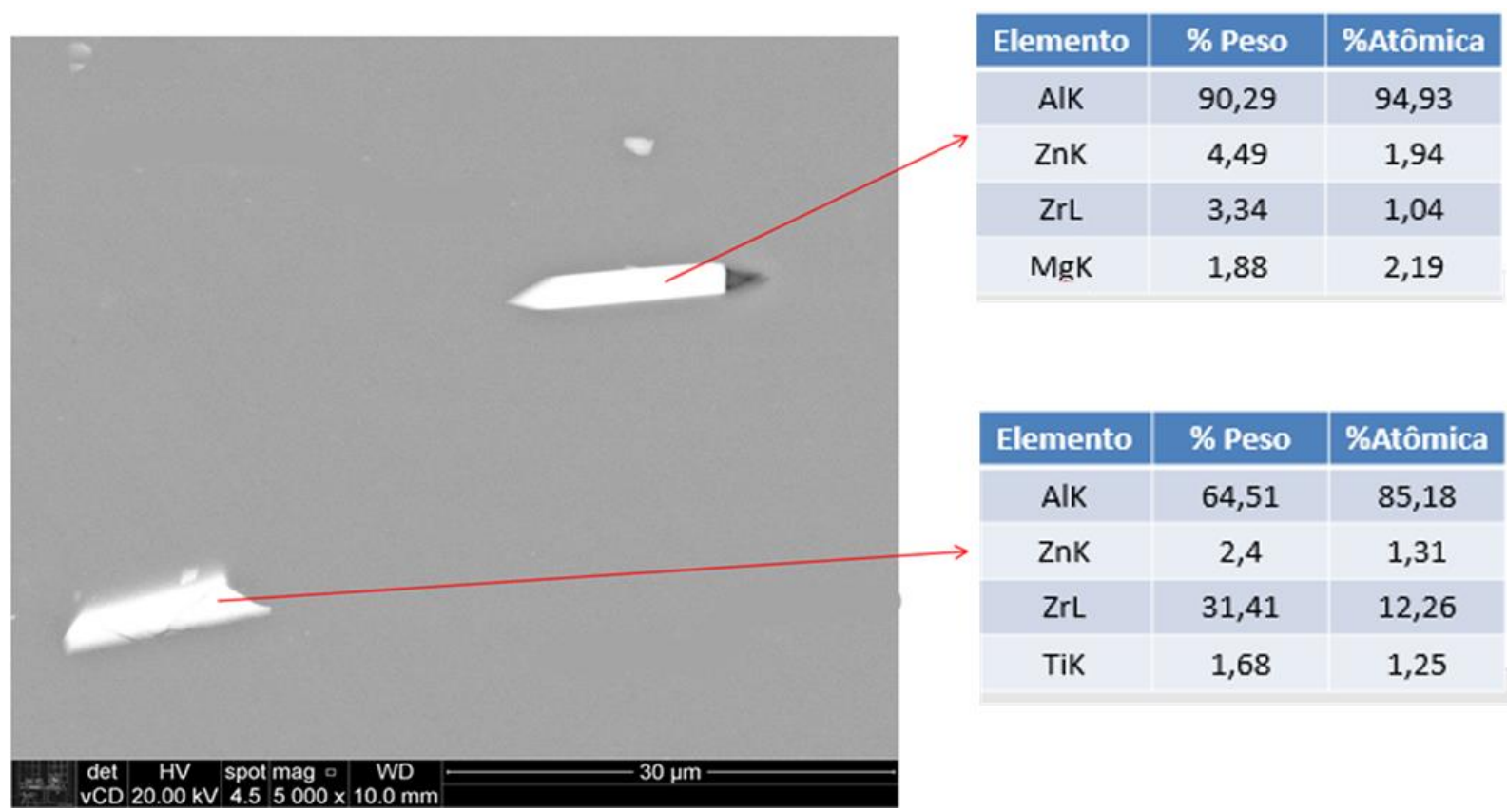

Figura 72 - Micrografia obtida por microscopia eletrônica de varredura da amostra extrudada. Os intermetálicos encontrados (junto com as análises via EDS) são mostrados na imagem

Além do $\mathrm{Al}_{3}(\mathrm{Zr}, \mathrm{Ti})$, também foram encontrados intermetálicos (dispersoides) com elevado teor de $\mathrm{Zn}, \mathrm{Mg}$ e $\mathrm{Fe}$, conforme indicado pela análise de EDS mostrada na Figura 73. Nota-se a diferença entre a morfologia das partículas de segunda fase (compare com a Figura 63) da amostra extrudada em relação às amostras brutas de fundição e homogeneizadas. Tal diferença de aspecto deve ter origem no processamento mecânico (extrusão) que promove a dispersão desses particulados ao longo da matriz rica em alumínio. Além disso, como o processamento foi realizado em temperatura elevada o suficiente (e foi seguido de resfriamento em água), isso explicaria a solubilização e a ausência de intermetálicos solúveis na matriz, como o $\mathrm{MgZn}_{2}$. 


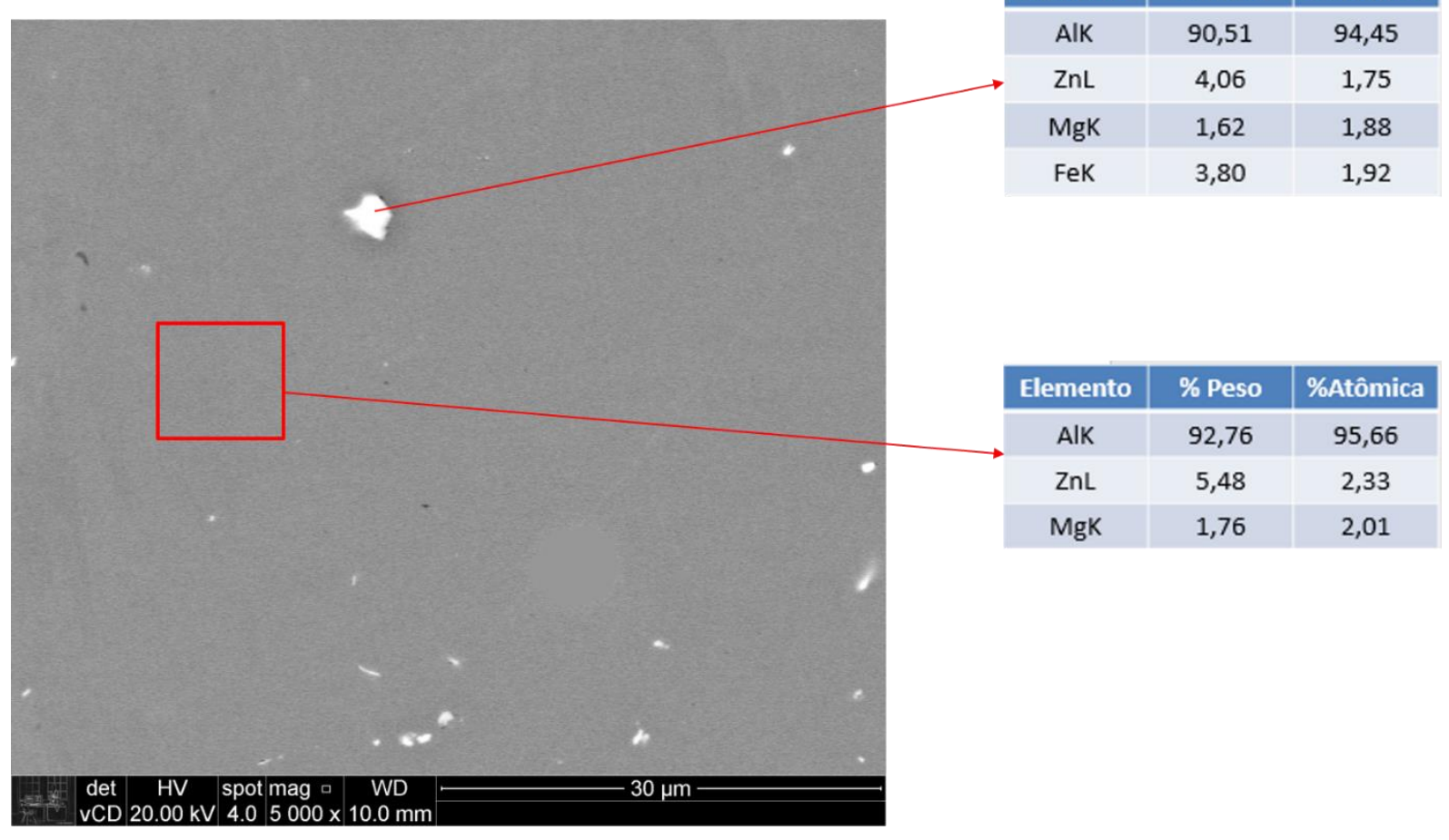

Figura 73 - Micrografia obtida por microscopia eletrônica de varredura da amostra extrudada. Os intermetálicos encontrados (junto com as análises via EDS) são mostrados na imagem

$A$ análise via difratometria de raios- $X$ complementa as observações via MEV e permite a identificação da fase $\mathrm{Al}_{3} \mathrm{Ti}$, além da matriz rica em alumínio. A identificação foi realizada com auxílio do software HighScore Plus e das fichas ICSD 98-006-1051 (Alumínio) e ICSD 98-008-2227 ( $\mathrm{Al}_{3} \mathrm{Ti}$ ). A Figura 74 mostra o difratograma (obtido a partir da superfície de extrusão, após preparação metalográfica padrão) e a indicação dos picos relativos às fases encontradas. Nota-se que para alguns picos (das fichas padrão), os valores de $2 \theta$ relativos ao $\mathrm{Al}$ e ao $\mathrm{Al}_{3} \mathrm{Ti}$ se encontram muito próximos (como por exemplo para $2 \theta \cong 39^{\circ}$ e $2 \theta \cong 65^{\circ}$ ), sendo possível que ocorra o fenômeno de superposição de picos nos intervalos mencionados.

Não foram encontrados picos associados à presença do dispersóide $\mathrm{Al}_{3} Z r$. É possível que em virtude da baixa fração volumétrica, tal fase não tenha sido detectada pela técnica de difração de raios $\mathrm{X}$, que embora precisa, apresenta limite de detecção pobre. 


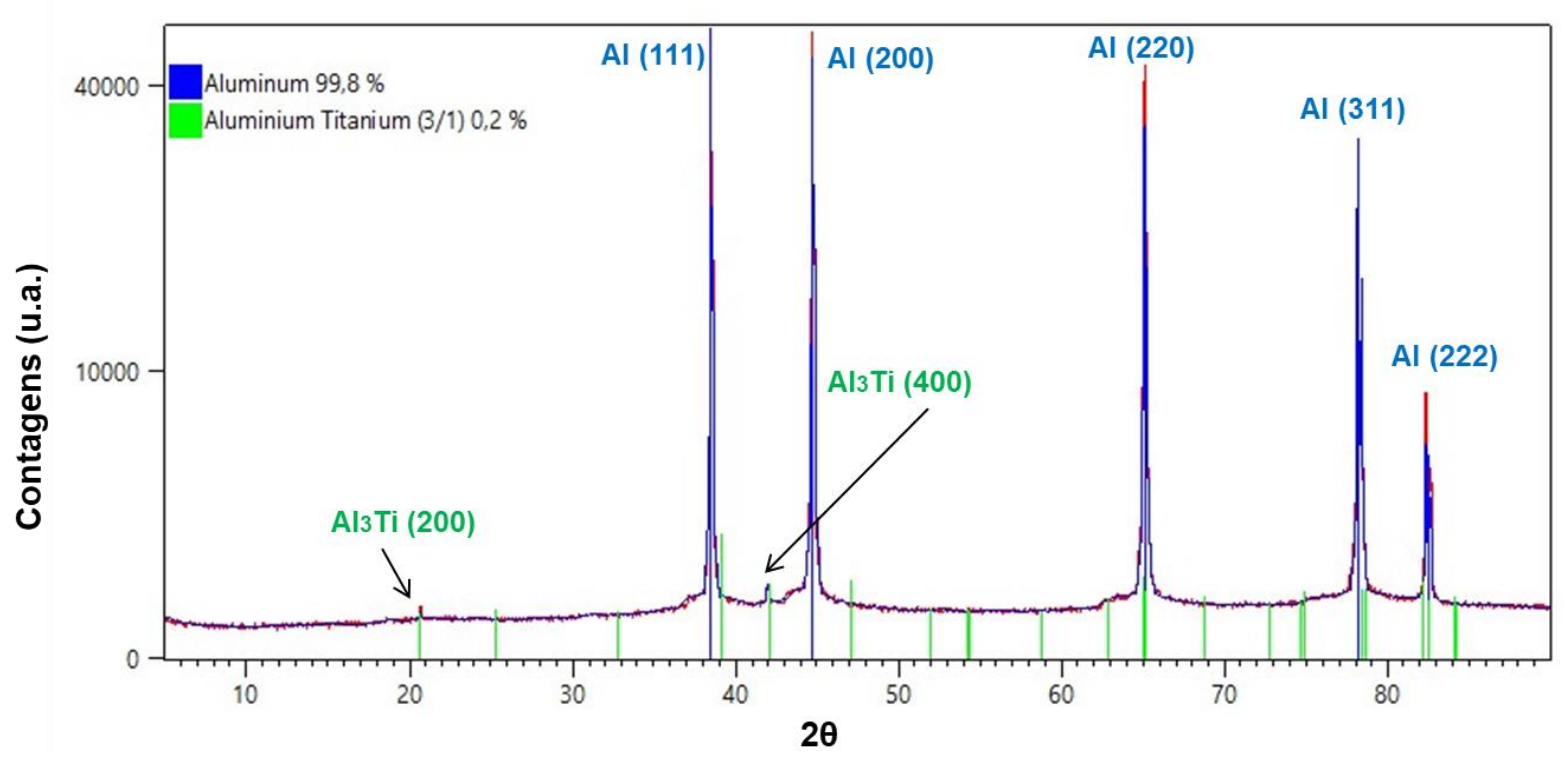

Figura 74 - Difratograma da AA 7108 extrudada. São indicadas as famílias de planos relativas à cada um dos picos identificados. Abaixo da curva, são apontadas as posições dos picos encontradas nas fichas padrão mencionadas

\subsubsection{Medidas de dureza Vickers}

A Figura 75 mostra o mapeamento (com escala de cores) de dureza realizado com as informações coletadas do ensaio. A dureza média encontrada foi $84,3 \pm 5,8$ HV e não foram encontradas diferenças significativas entre o centro e a periferia da amostra, conforme poderia se esperar.

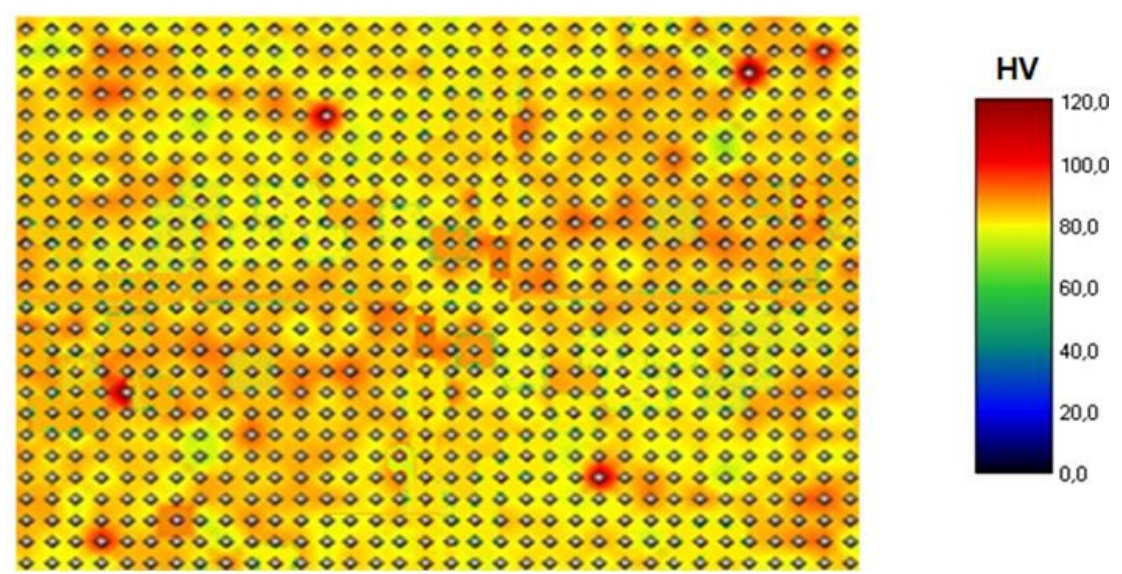

Figura 75 - Mapeamento de dureza Vickers realizado sobre a seção transversal da barra extrudada da AA 7108

\subsubsection{Textura cristalográfica}

A Figura 76 mostra mapas de orientações obtidos via EBSD. As análises foram realizadas em duas regiões da superfície de extrusão: Uma próxima à periferia e uma 
próxima ao centro. Como colocado anteriormente, o tamanho médio dos grãos localizados no centro é significativamente maior (tamanho médio em torno de $130 \mu \mathrm{m}$ ) em relação ao tamanho médio dos grãos localizados nas regiões periféricas $(25 \mu \mathrm{m}$ em média), excetuando-se, obviamente, a PCGZ. Nota-se um predomínio das cores avermelhadas/roseadas para ambos os casos. Isso significa que os planos cristalográficos da família $\{100\}$ tendem a estar alinhados com a superfície de extrusão

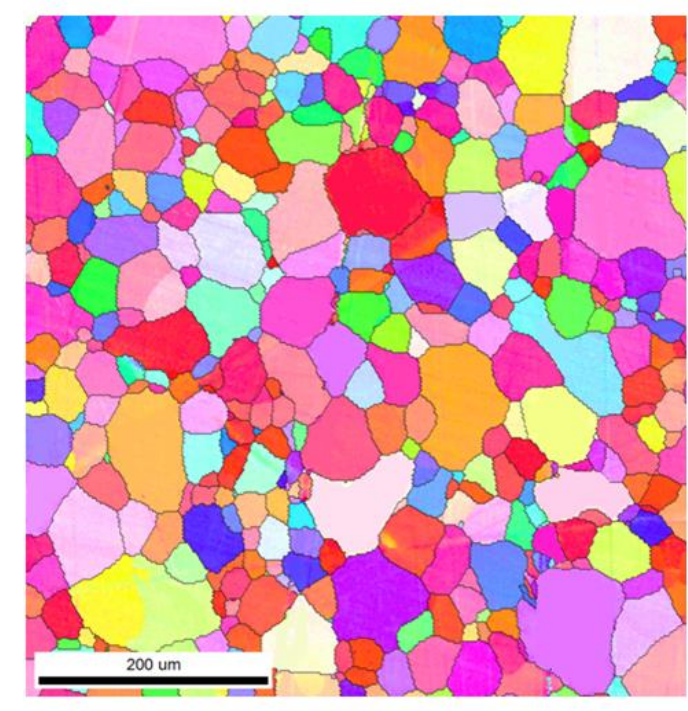

(a)

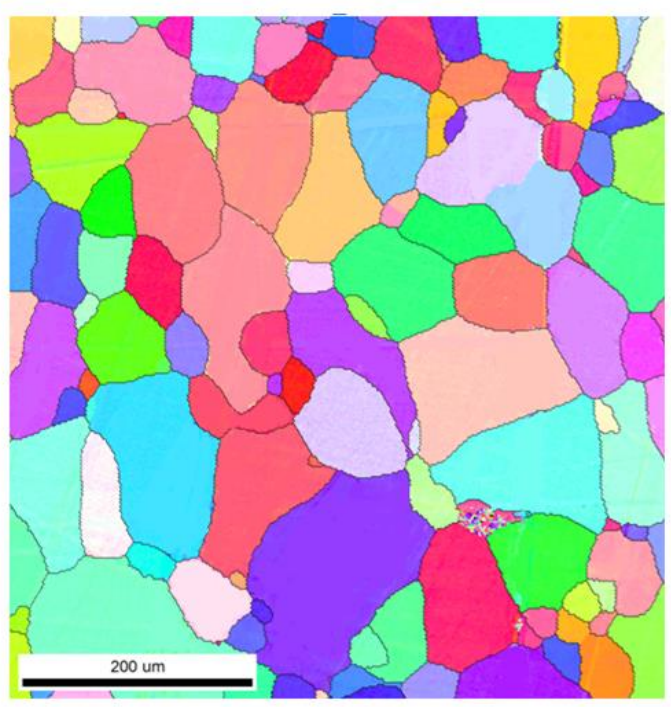

(b)

Figura 76 - Mapeamento de orientações (EBSD) da superfície de extrusão na (a) periferia e (b) centro da AA 7108

A Figura 77 mostra as mesmas regiões analisadas na Figura 76, mas dando destaque para a mesotextura, ou seja, para a orientação entre os grãos. Nessa representação, os contornos de coloração azul representam contornos de médio ângulo (valores compreendidos entre $5^{\circ}$ e $15^{\circ}$ ), enquanto os contornos de colocação preta representam contornos de alto ângulo (valores de desorientação superiores a $15^{\circ}$ ). Nota-se a quase totalidade de contornos de alto ângulo indicando uma microestrutura de grãos recristalizados com baixa densidade de subgrãos (que, na escala apresentada, sequer são visíveis). 


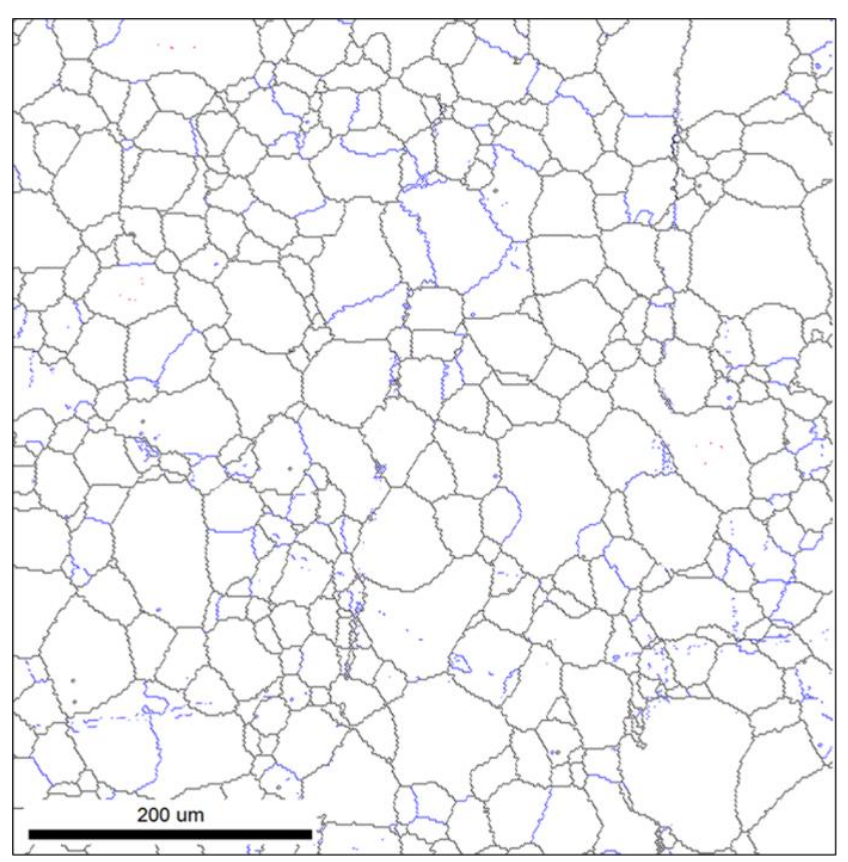

(a)

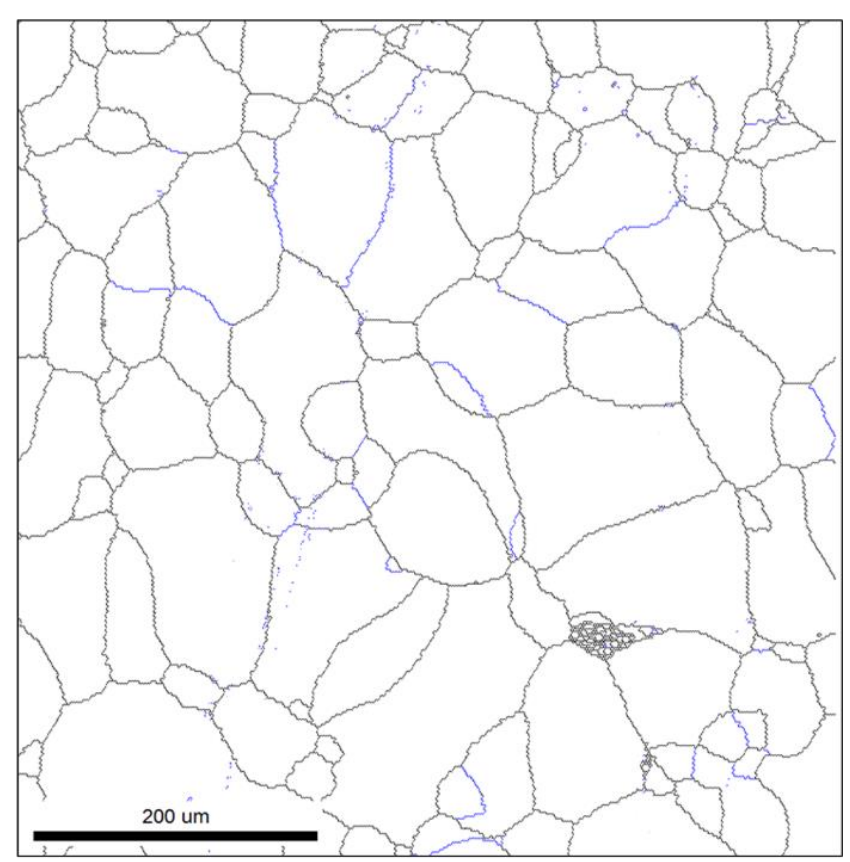

(b)

Figura 77 - Mapeamento de orientações (EBSD) da superfície de extrusão na (a) periferia e (b) centro da AA 7108. Os contornos representados na coloração azul representam contornos de médio ângulo, enquanto os contornos representados na coloração preta representam contornos de alto ângulo

As Figuras 78 e 79 mostram as seções de $\varphi_{2}=$ constante da FDO relativas à superfície de extrusão. A análise foi feita com emprego do software OIM Analysis ${ }^{\mathrm{TM}}$ utilizando os dados obtidos via EBSD. Observa-se que a componente mais forte, denominada cubo (com ângulos de Euller $\varphi 1=90^{\circ}, \phi=0, \varphi 2=0$ ), possui intensidade $f(g)=9,1$, uma componente de textura típica de recristalização [117]. Já a análise realizada sobre a região central, mostra a presença das componentes (013) <031> (com ângulos de Euller $\varphi 1=90^{\circ}, \phi=20^{\circ}, \varphi 2=0$, próxima à localização da componente cubo) e Goss (com ângulos de Euller $\varphi 1=90^{\circ}, \phi=90^{\circ}, \varphi 2=45^{\circ}$ ). 

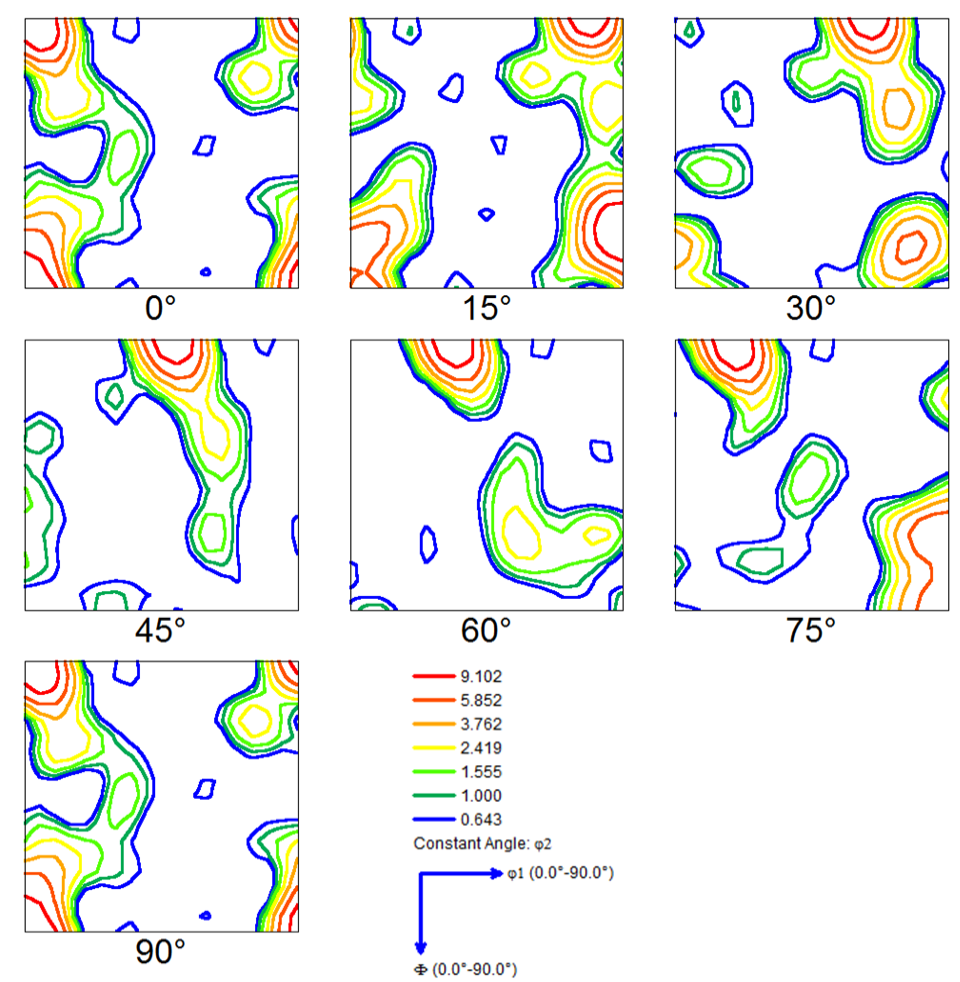

Figura 78 - FDO obtida via EBSD X relativa à AA 7108 extrudada. A análise foi realizada na superfície de extrusão em região próxima à periferia
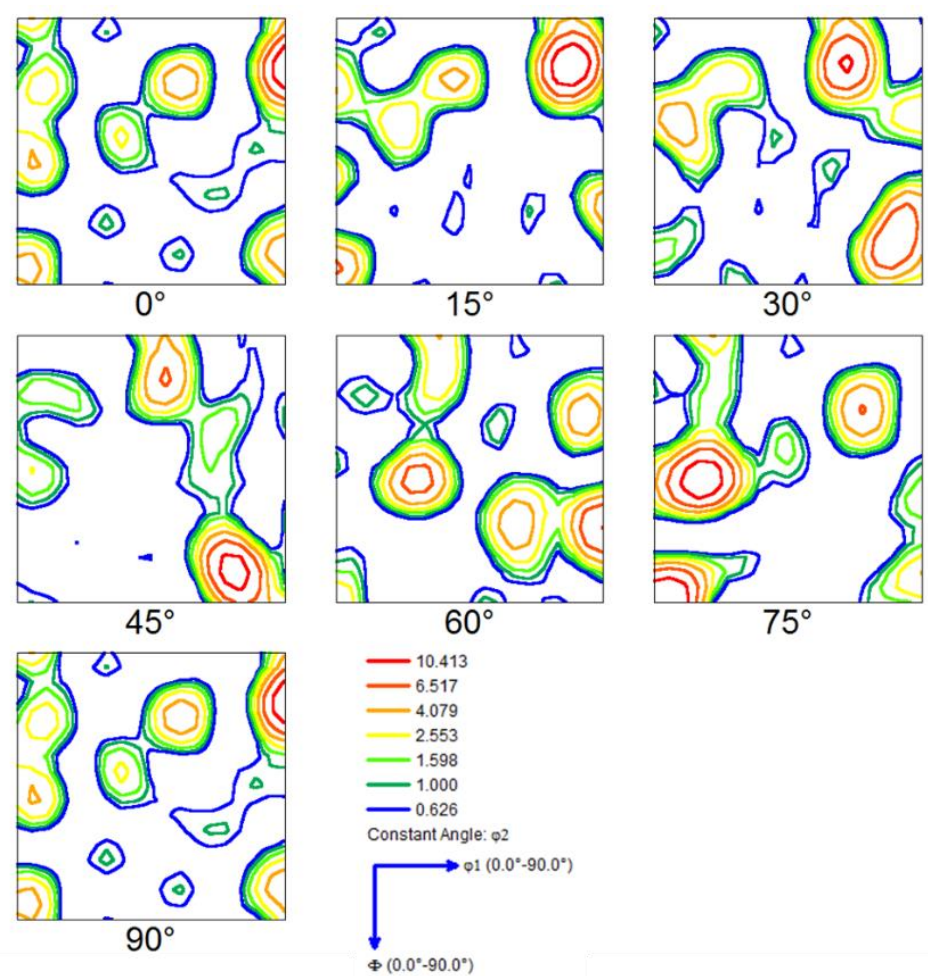

Figura 79 - FDO obtida via EBSD X relativa à AA 7108 extrudada. A análise foi realizada na superfície de extrusão em região próxima ao centro 
Embora o mapeamento de orientações via EBSD permita a observação "grão a grão" (microtextura), tal técnica oferece parâmetros estatísticos muito pobres, uma vez que a área analisada é bastante reduzida e (possivelmente) pouco representativa do material estudado. Análises de textura estatisticamente mais confiáveis podem ser obtidas por difratometria de raios X. A Figura 80 mostra as figuras de polo obtidas (via DRX) para a superfície de extrusão, para $1 / 4$ abaixo da superfície e para o centro da amostra (1/2). A família de planos associada a cada figura está indicada acima de cada imagem (Exemplo: Arquivo SE - 111 significa superfície de extrusão e família de planos (111)).
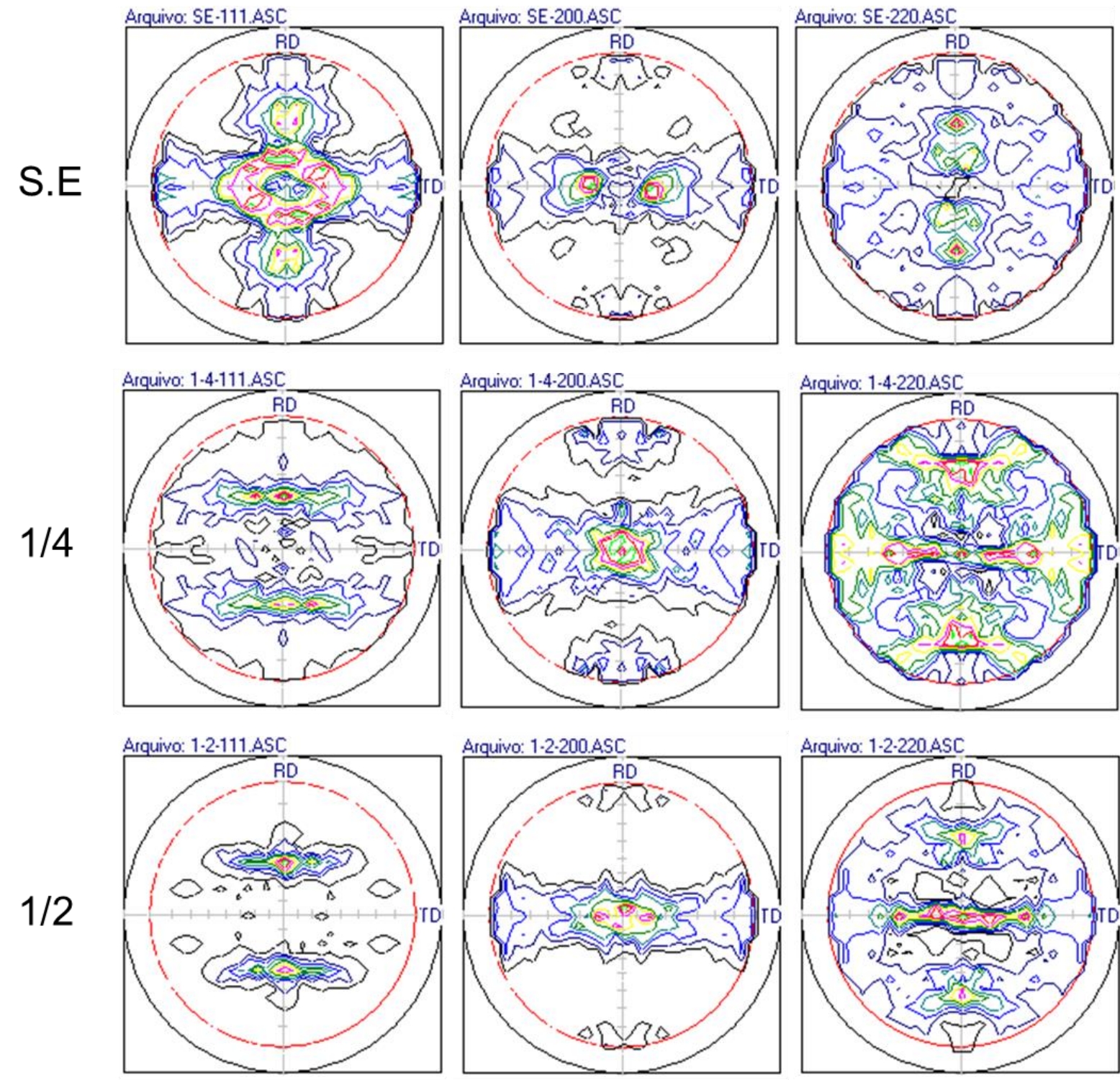

Figura 80 - Figuras de pólo obtidas por análise via difração de raios X relativas à superfície de extrusão (S.E.), 1/4 abaixo da superfície e para o centro da amostra (1/2) 
As figuras de polo têm pouca utilidade (direta) na avaliação quantitativa da textura, de forma que uma descrição mais completa é feita por meio das funções distribuição de orientação (FDO). As Figuras 81, 82 e 83 mostram as FDOs (obtidas por meio das figuras de pólo) relativas à AA 7108 no estado inicial. Tais FDOs foram obtidas das amostras de supercífie de extrusão, 1/4 abaixo dessa superfície e na metade da barra extrudada, conforme explicado com maiores detalhes na seção Materiais e Métodos. Na região da superfície (SE) foi observada a presença da componente $\{001\}<100\rangle$ denominada cubo (com ângulos de Euller $\varphi 1=0, \phi=0$, $\varphi 2$ $=0$ ) com intensidade $\mathrm{f}(\mathrm{g})=10,3$, como é possível observar na FDO da Figura 81 .
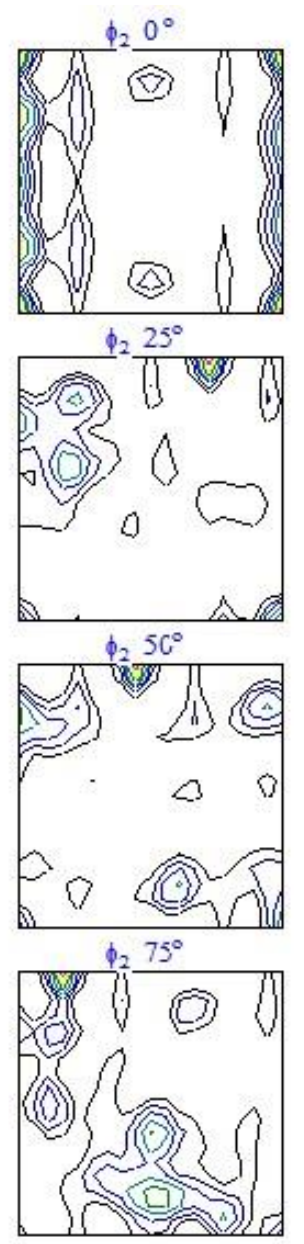
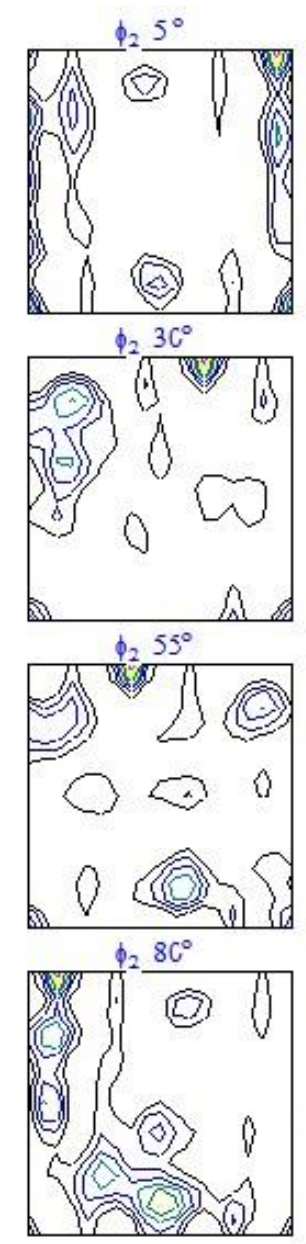
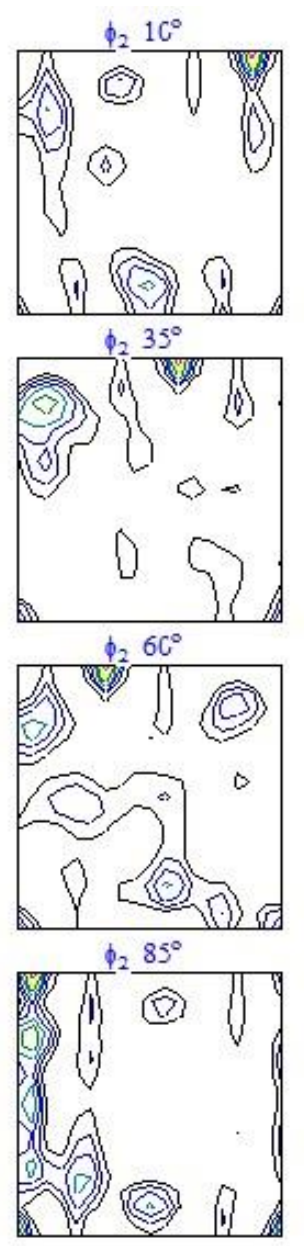
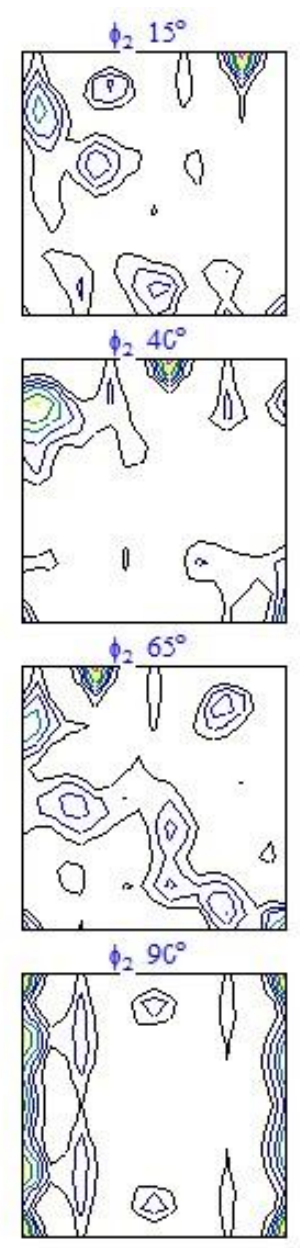
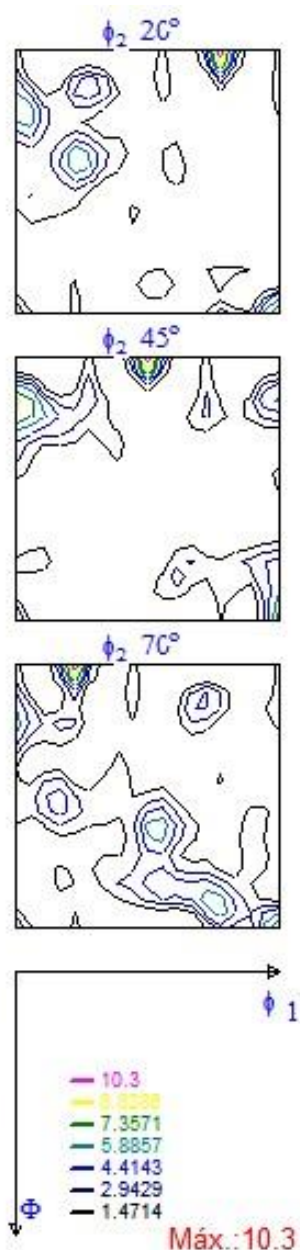

Figura 81 - FDO obtida via difratometria de raios $X$ relativa à AA 7108 extrudada. A análise foi realizada na superfície de extrusão

$\mathrm{Na}$ região da metade da espessura (representada nesse trabalho por $1 / 2$ ) observou-se a presença de textura tipo cubo $\{001\}<100>$ de maior intensidade $(\mathrm{f}(\mathrm{g})=$ 16,4). Tal componente pode ser visualizada na FDO apresentada na Figura 82. Adicionalmente, uma componente do tipo Goss $\{011\}<100>$ (intensidade $\mathrm{f}(\mathrm{g})=14$ ) 
também pode ser observada na região da metade da barra. A presença dessa componente não é típica do fenômeno de recristalização das ligas de alumínio. Componentes de textura do tipo Goss já foram encontradas em outros trabalhos com ligas de alumínio [1] e podem ser atribuídas às menores taxas de resfriamento que ocorrem no centro da barra (em relação à periferia) durante o processamento mecânico a quente [49].
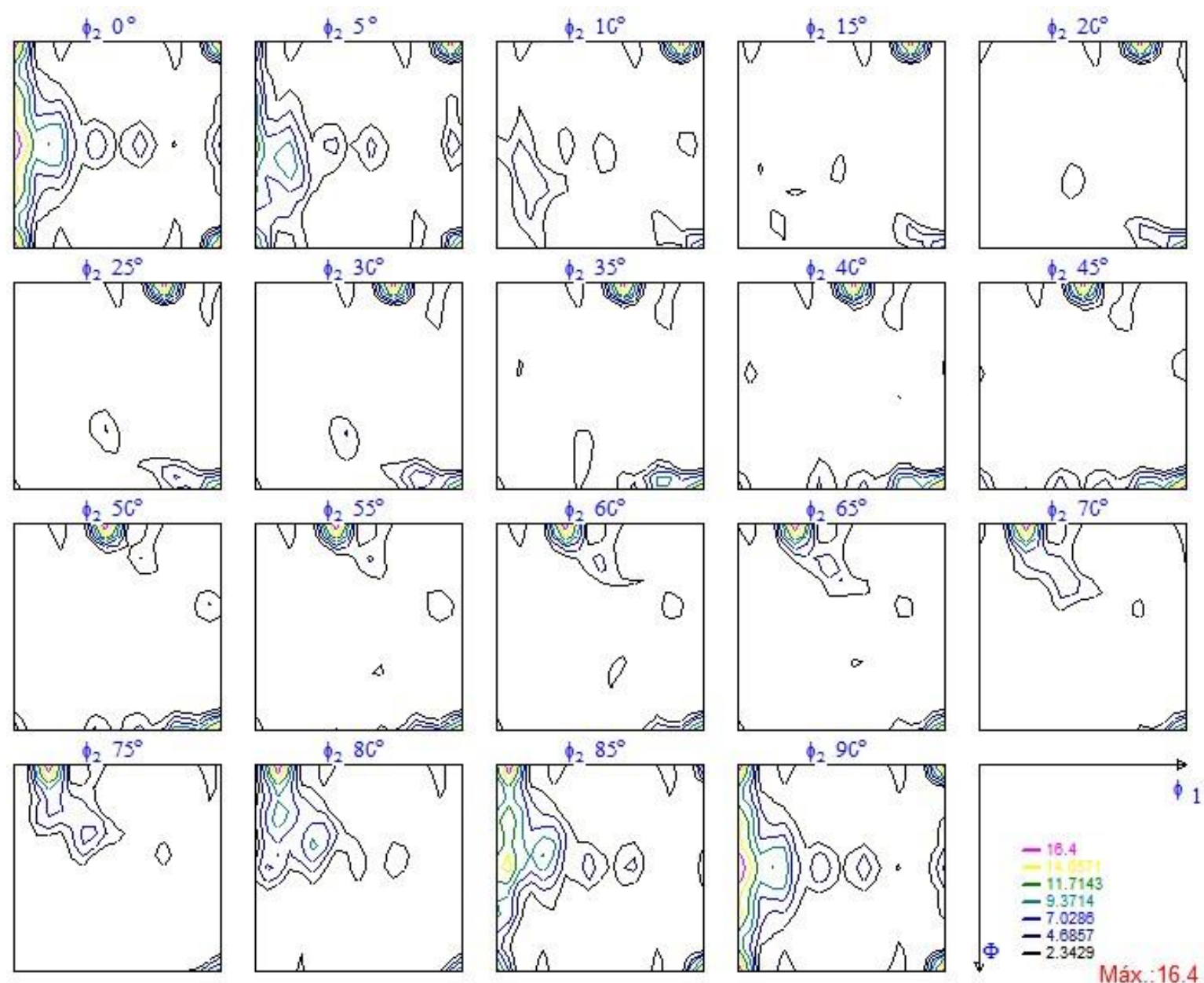

Figura 82 - FDO relativa à AA 7108 extrudada. A análise foi realizada na metade da barra, em superfície paralela à superfície de extrusão

Na posição $1 / 4$, a função densidade de orientações (Figura 83) mostra um estado de transição entre as componentes encontradas na superfície de extrusão e na superfície $1 / 2$. 


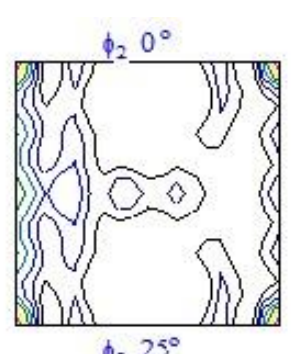

$\phi_{2} 25^{\circ}$
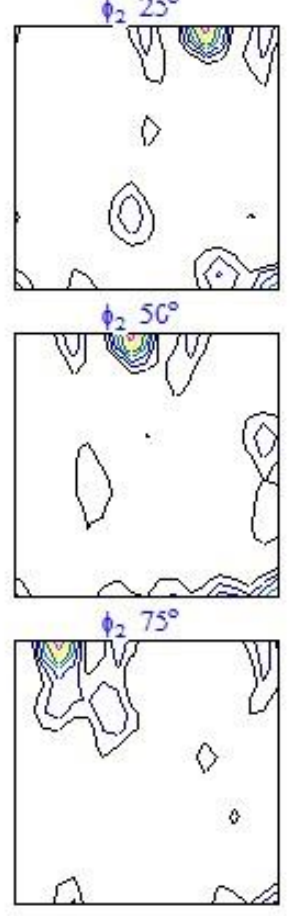
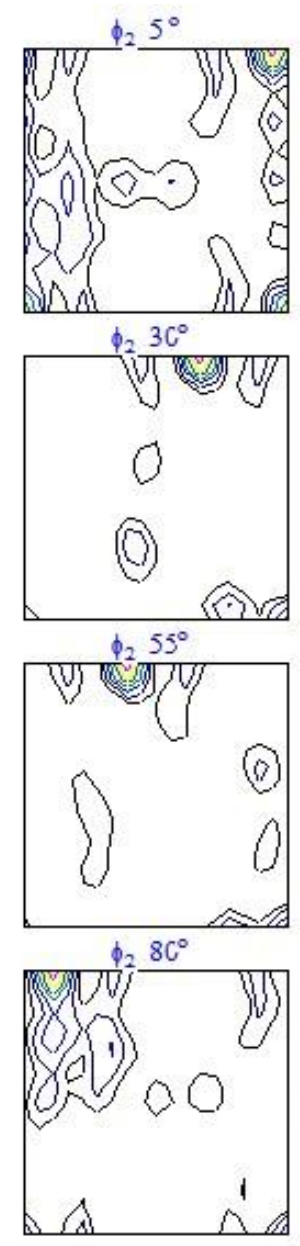
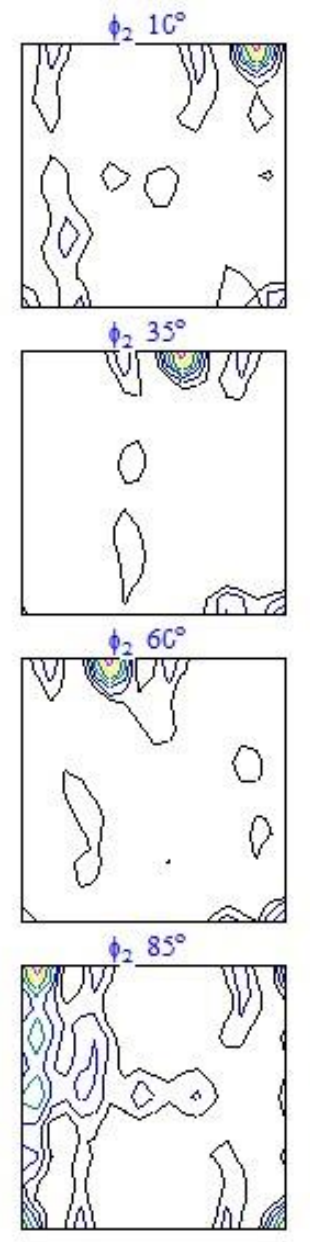
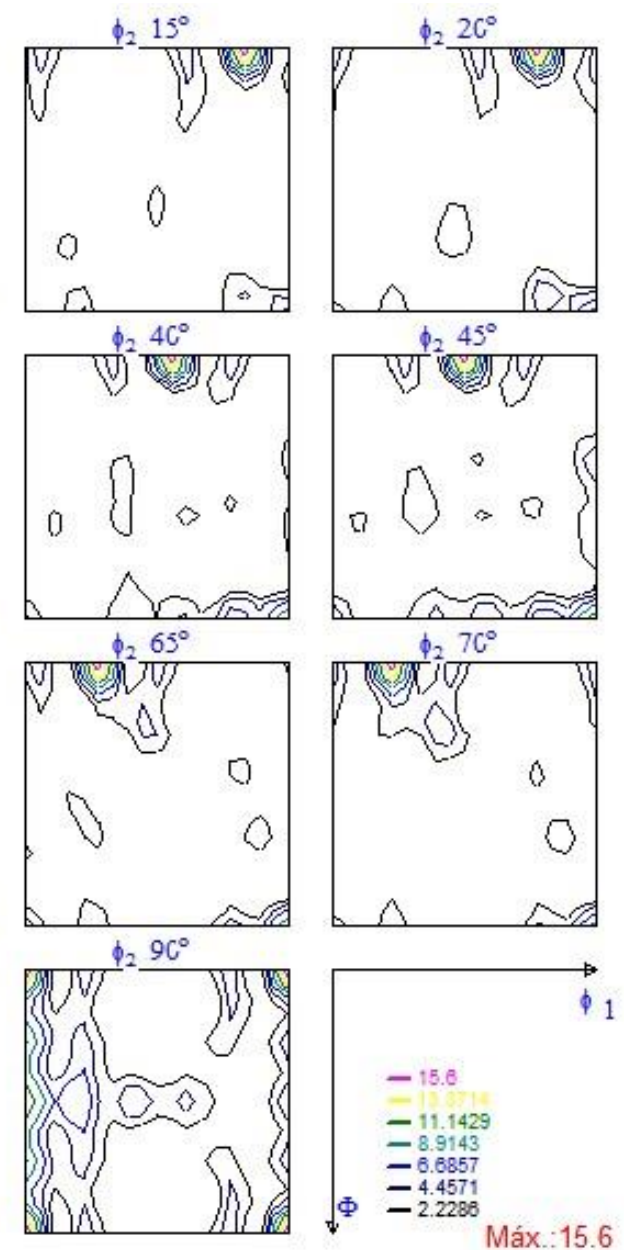

Figura 83 - FDO relativa à AA 7108 extrudada. A análise foi realizada a 11/4 de espessura abaixo da superfície de extrusão

O gráfico de fibra correspondente aos ângulos de Euler $\varphi 1=0, \varphi 2=0$ e $0<\phi<$ $45^{\circ}$ é exibido na Figura 84. Por meio desse, é possível notar com mais clareza a predominância da textura tipo Cubo na superfície de extrusão e a predominância da textura tipo Goss associadas às regiões mais centrais da barra extrudada, conforme colocado anteriormente. 


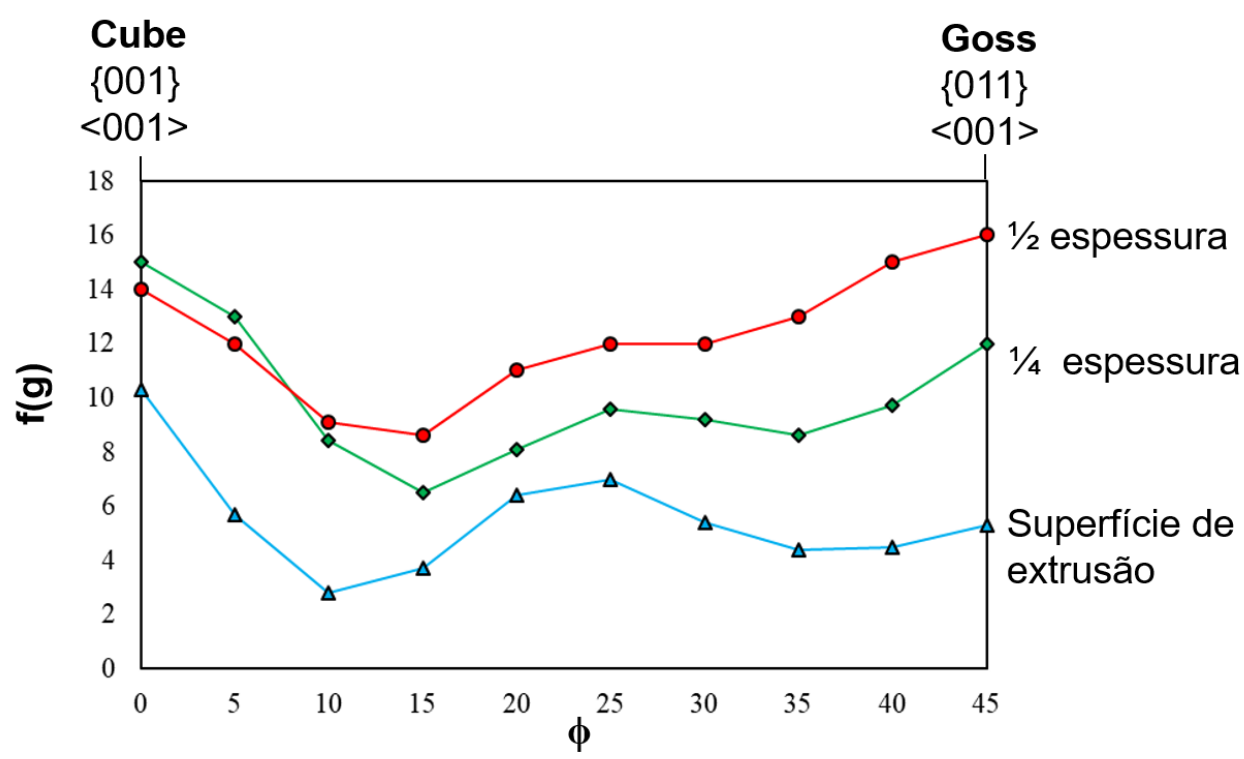

Figura 84 - Gráfico de fibra ao longo da família de direções $<100>\left(\varphi_{1}=0, \varphi_{2}=0\right.$ e $\left.0<\phi<45^{\circ}\right)$ relativo às amostras extrudadas ao longo da espessura

\subsubsection{Textura cristalográfica da zona de grãos grosseiros periféricos (PCGZ)}

Com o objetivo de estudar a textura cristalográfica da zona de grãos grosseiros, foram utilizadas as técnicas de EBSD e difratometria de raios $\mathrm{X}$. Inicialmente, estimouse a profundidade da penetração dos raios- $X$ na amostra de acordo com a metodologia descrita a seguir.

Seja $I_{D}$ a intensidade do feixe de raios $\mathrm{X}$ que é difratada por uma dada família de planos cristalinos. A fração da intensidade difratada que é atribuída a uma camada superficial de espessura $x$ (denominada $G_{x}$ ) pode ser expressa por:

$$
G_{x}=\frac{\int_{0}^{x} d I_{D}}{\int_{0}^{\infty} d I_{D}}
$$

Onde o denominador expressa a intensidade difratada por uma amostra do material de "espessura infinita". Cullity [121] coloca que amostras com espessuras da ordem de décimos de polegada $(1$ polegada $=2,54 \mathrm{~cm}$ ) podem ser, para efeitos de cálculo de penetração de raios $\mathrm{X}$, consideradas como possuindo espessura infinita. Dessa forma, considera-se de maneira arbitrária, que a contribuição da superfície de espessura x para o aumento da intensidade difratada é de $95 \%, 99 \%$ ou até mesmo $99,9 \%$. Assim, é possível ignorar a contribuição proveniente do material abaixo da superfície de espessura x para a intensidade do feixe difratado. 
O cálculo com boa precisão do valor de $G_{x}$ em função do ângulo $\theta$ (proveniente da lei de Bragg) pode ser realizado com emprego da expressão:

$$
G_{x}=1-\exp \left(\frac{-2 \mu x}{\operatorname{sen} \theta}\right)
$$

Onde $\mu$ é o coeficiente de absorção do metal ou liga metálica. A equação anterior pode reescrita de forma a colocar a espessura $x$ em evidência:

$$
x=\frac{\ln \left(\frac{1}{1-G_{x}}\right) \cdot \operatorname{sen} \theta}{2 \mu}
$$

Fazendo:

$$
K_{x}=\ln \left(\frac{1}{1-G_{x}}\right)
$$

Chega-se a:

$$
x=\frac{K_{x} \cdot \operatorname{sen} \theta}{2 \mu}
$$

O coeficiente de absorção $\mu$ da liga pode ser estimada por meio da média ponderada das absorbâncias dos elementos que a constituem. A Tabela 9 mostra os dados utilizados para calcular a coeficiente de absorção mássico para cada um dos elementos químicos que compõe a liga estudada.

Tabela 9 - Densidade e coeficiente de absorção mássica dos elementos que constituem a AA 7108 para a radiação CuKa [122]

\begin{tabular}{ccc}
\hline Elemento & Densidade $-\rho\left(\mathbf{g} / \mathbf{c m}^{3}\right)$ & $\begin{array}{c}\text { Coeficiente de } \\
\text { absorbância }-\mu / \rho\left(\mathbf{c m}^{2} / \mathbf{g}\right)\end{array}$ \\
\hline $\mathbf{A l}$ & 2,7 & 50,2 \\
$\mathbf{Z n}$ & 7,13 & 59,5 \\
$\mathbf{M g}$ & 1,74 & 40,9 \\
$\mathbf{T i}$ & 11,87 & 222,2 \\
$\mathbf{Z r}$ & 6,51 & 136,8 \\
\hline
\end{tabular}

Em posse do valor do coeficiente de absorção mássico $(\mu / \rho)$ e da densidade $(\rho)$ da AA 7108, foram adotados (de forma arbitrária) valores de $G_{x}$ que variavam de 0,1 
a 0,99 e construiu-se o gráfico que expressa a profundidade de penetração da radiação $\mathrm{Cu}-\mathrm{K} \alpha$ em função de $\mathrm{G}_{x}$ para cada uma das famílias de planos cristalográficos do sistema CFC que promovem o fenômeno de difração. Nota-se que mesmo para valores de $G_{x}=0,9$, a máxima profundidade calculada de penetração gira em torno de $75 \mu \mathrm{m}$. A Figura 71 mostra que a camada de grãos grosseiros que se pretende estudar tem cerca de $300 \mu \mathrm{m}$ de espessura. Ou seja, mesmo para valores elevados de $G_{x}$, conclui-se que a penetração dos raios $X$ atinge somente os grãos mais próximos à superfície, ou seja, atinge somente os grãos grosseiros dos quais se planeja estudar a textura cristalográfica. A Figura 85 exibe graficamente a estimativa da penetração dos raios X para a liga AA 7108 .

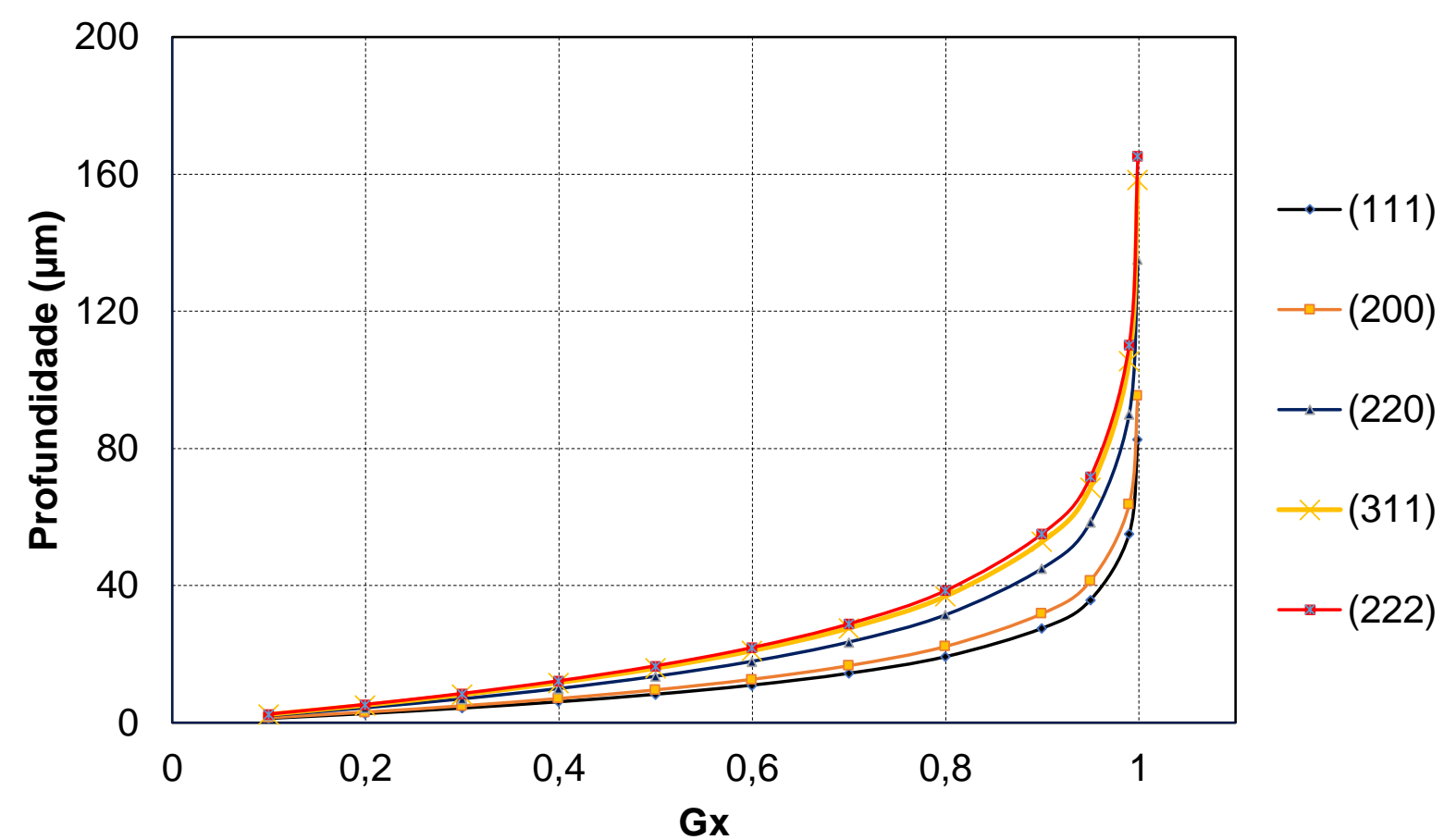

Figura 85 - Estimativa da profundidade de penetração da radiação Cu-Ko em função de $G_{x}$ para cada família de planos do sistema CFC que promovem a difração da radiação

A Figura 86 mostra os difratogramas da superfície de extrusão da AA 7108 no estado como recebido. $O$ difratograma do item a, corresponde à amostra que foi submetida à preparação metalográfica (lixamento e polimento), enquanto 0 difratograma do item b é relativo à amostra que não foi preparada. Experimentalmente, nota-se que alguns décimos de milímetro da espessura de uma dada amostra são consumidos durante a preparação metalográfica, especialmente durante a etapa de 
lixamento, fator que no caso da liga estudada, promove a remoção da camada de grãos grosseiros.

Nota-se que a intensidade relativa dos picos dos difratogramas apresentados diferem bastante entre si. Enquanto os picos mais intensos do difratograma "a" são relativos às famílias (200) e (220), no difratograma "b" o pico mais intenso corresponde ao (113). Embora a análise da intensidade relativa dos picos de difração não seja o método mais adequado para o estudo da textura cristalográfica, tal observação fornece, ao menos de maneira qualitativa, indícios de que a orientação preferencial da camada de grãos grosseiros difere bastante da orientação dos grãos abaixo dessa camada.

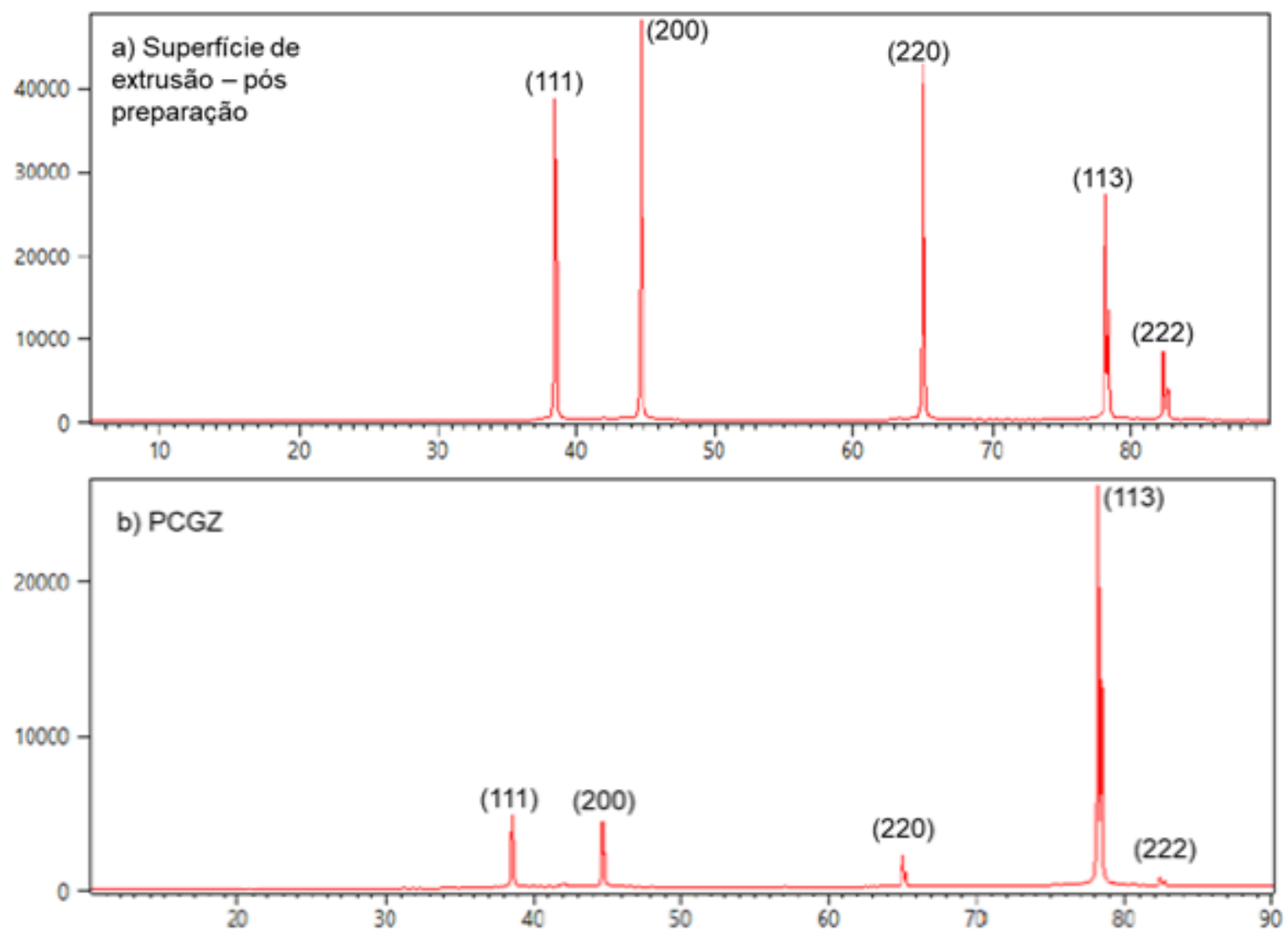

Figura 86 - Difratogramas da AA 7108 relativos à superfície de extrusão a) da amostra preparada (lixada e polida) e b) da amostra sem preparação. A diferença de intensidade relativa entre os picos dos difratogramas indica a possibilidade de diferentes componentes de textura estarem presentes para cada caso

Utilizando-se o procedimento apresentado na Seção 4.1, estimou-se o valor do parâmetro de rede em função dos dados obtidos via difração de raios $X$ para as amostras SE e PCGZ. Para a superfície SE, o valor calculado foi $0,4058 \mathrm{~nm}$ e para a PCGZ o valor calculado foi $0,4057 \mathrm{~nm}$ (vide Figura 87). Essa diferença de valores está 
possivelmente associada à concentração de átomos de soluto em cada uma das regiões avaliadas. Maiores teores de soluto em ligas metálicas tendem a distorcer a estrutura cristalina de modo a aumentar o parâmetro de rede em relação ao metal puro (vide o parâmetro de rede do alumínio de elevada pureza: 0,4049 nm). Como a região associada à PCGZ é resfriada (pós processamento) mais rapidamente, a solubilização de intermetálicos acontece de maneira mais eficiente e a região se torna mais concentrada em termos de $\mathrm{Zg}$ e $\mathrm{Mg}$ em solução sólida, o que implica em um maior parâmetro de rede quando comparado ao material que se encontra mais próximo ao centro da seção transversal do extrudado.
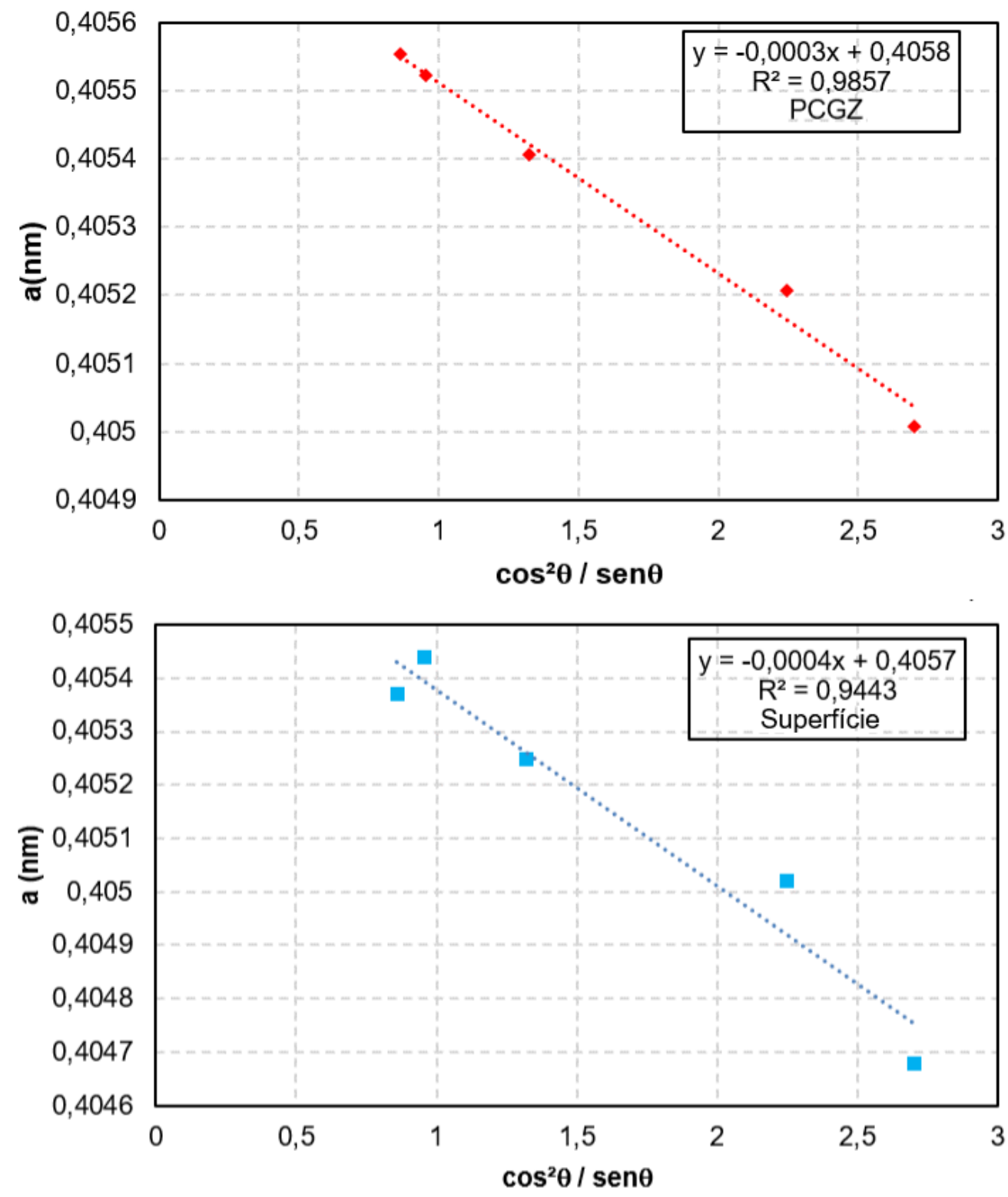

Figura 87 - Gráficos a x $\cos ^{2} \theta /$ sen $\theta$ para a superfície de extrusão (obtida pela remoção da camada de grãos grosseiros) e para a PCGZ. O termo independente indicado nas equações indicadas em cada gráfico corresponde à estimativa para o valor do parâmetro de rede da matriz rica em Al 
A Figura 88 mostra o mapa de orientação obtido via EBSD para a amostra AA 7108, realizada na seção transversal, conforme indicado esquematicamente ao lado do mapeamento. A análise foi realizada próxima à fronteira do material com a baquelite, de modo que fosse possível realizar o mapeamento da PCGZ. É possível notar algumas imperfeições relativas à preparação (riscos), principalmente na região inferior (mais próxima da borda limite entre amostra e baquelite). Tais imperfeições decorrem em função da dificuldade de se obter bom acabamento nessa região de interface entre a baquelite e a liga.

É possível notar (em função das diferentes cores atribuídas às diferentes orientações) que as componentes presentes na PCGZ são diferentes daquelas associadas às regiões abaixo da zona de grãos grosseiros (vide Figura 76). Não foram geradas figuras de polo ou FDOs a partir dos dados coletados, pois a pequena área analisada, somada ao elevado tamanho dos grãos presentes na região, resultaria em baixa representatividade estatística relativa e em uma figura de polo não representativa da textura real do material.

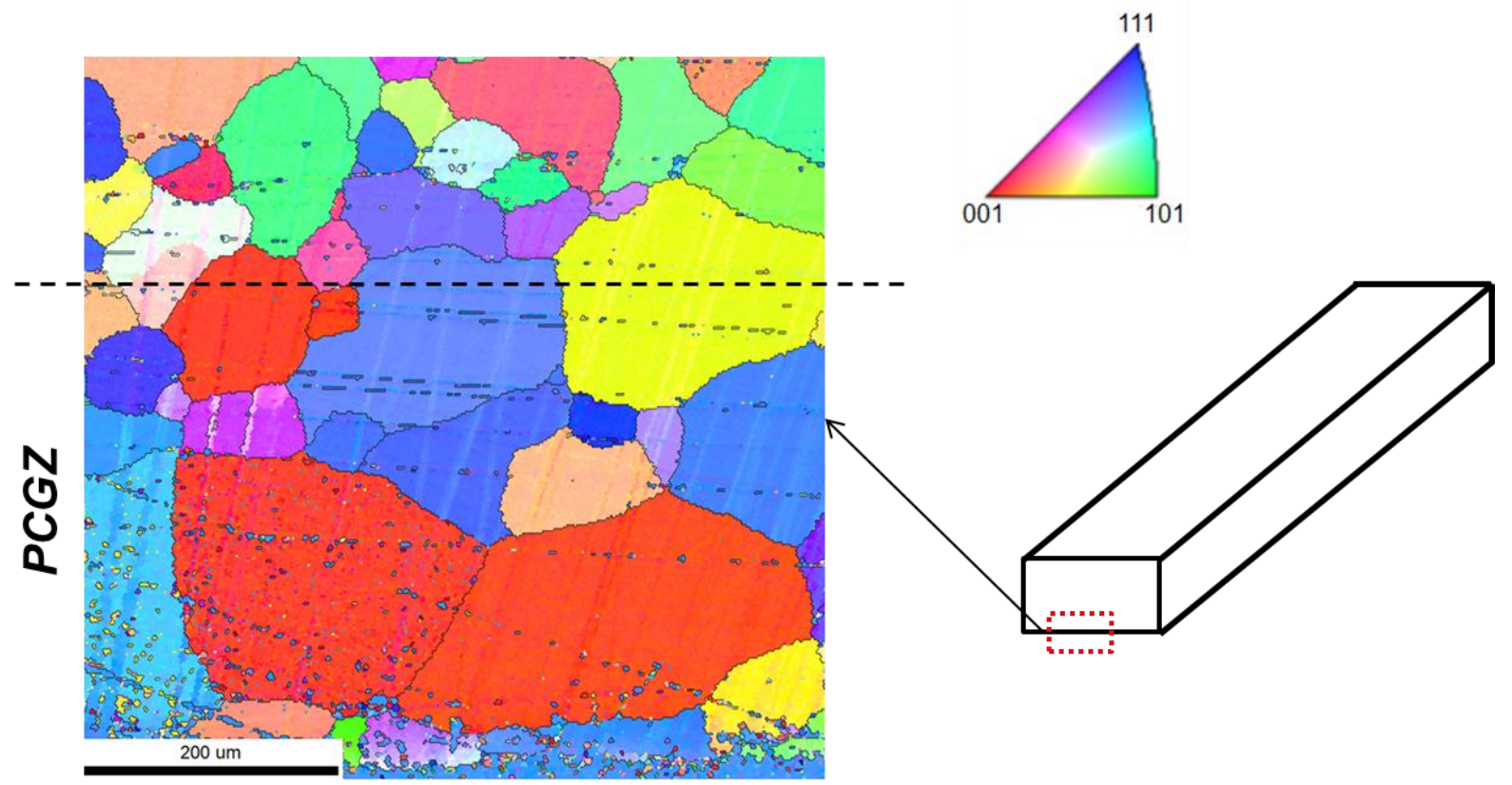

Figura 88 - Mapeamento de orientações (EBSD) da seção transversal. Imagem obtida próxima à fronteira amostra/baquelite.

A Figura 89 mostra figuras de polo associadas à PCGZ. O elevado grau de simetria observado indica confiabilidade com relação as FDOs obtidas a partir delas. 

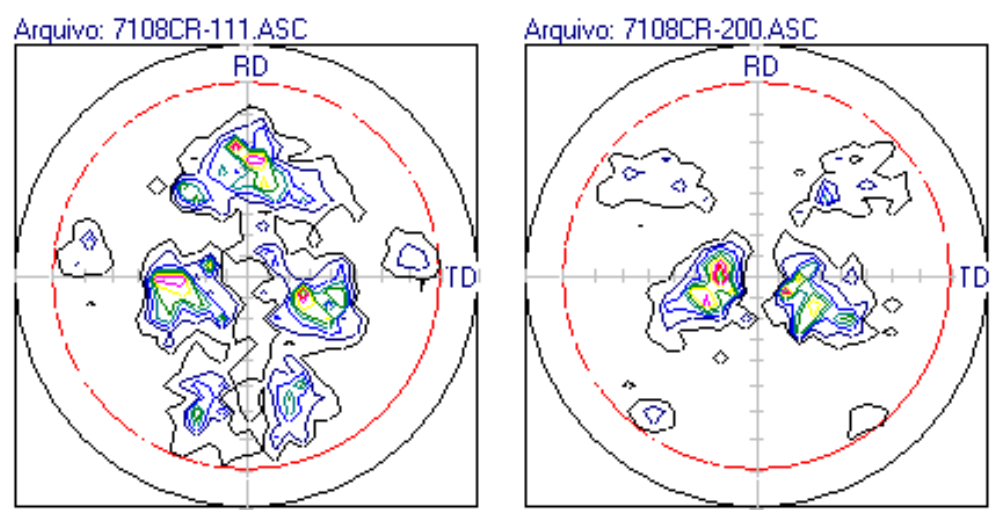

Figura 89 - Figuras de polo associadas à PCGZ.

A Figura 90 mostra a FDO relativa à superfície de extrusão, obtida via difratometria de raios $X$, mas sem preparação metalográfica, ou seja, abrangendo a PCGZ.. Nota-se a presença da componente $\{311\}<110>$, com ângulos de Euler $\varphi 1$ $=0, \varphi 2=45^{\circ}, \phi=35^{\circ}$ e intensidade máxima relativa $\mathrm{f}(\mathrm{g})=11,2$. O resultado é corroborado pela análise do difratograma (Figura 86) que mostra que existe (para as condições de processamento adotadas durante a extrusão) a tendência à formação de uma componente de textura associada à PCGZ. Tal componente associada à orientação preferencial dos grãos grosseiros difere bastante das componentes associadas aos grãos adjacentes (vide Figura 81). Sabendo que componentes de textura do tipo (113) já foram identificadas em ligas de alumínio que sofreram recristalização secundária [123] (crescimento de grão), infere-se que o mecanismo atuante na formação da PCGZ é o crescimento de grão, conforme será explicado a seguir. 


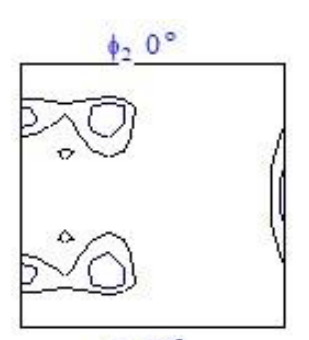

$\phi_{2} 25^{\circ}$

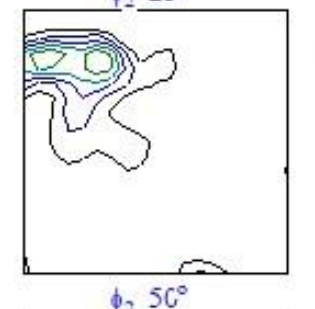

$\phi_{2} 5 \mathrm{C}^{\circ}$

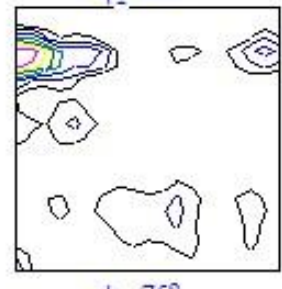

$\phi_{2} 75^{\circ}$

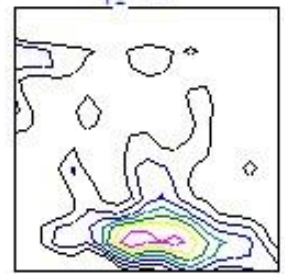

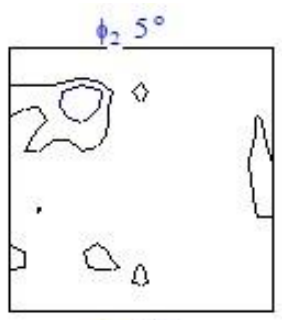

$\phi_{2} 3 \mathrm{C}^{\circ}$

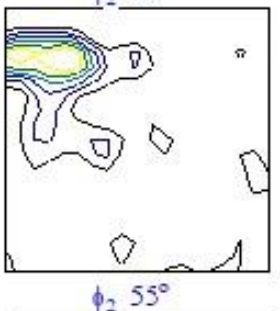

$\phi_{2} 55^{\circ}$

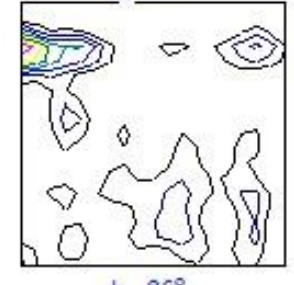

$\phi_{2} S C^{\circ}$

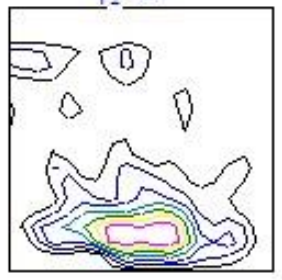

$\phi_{2} 10^{\circ}$

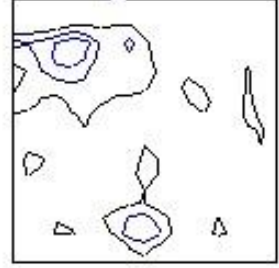

$\phi_{2} 35^{\circ}$

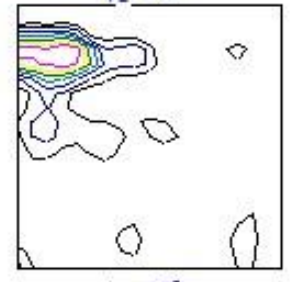

$\phi_{2} 6 \mathrm{C}^{\circ}$

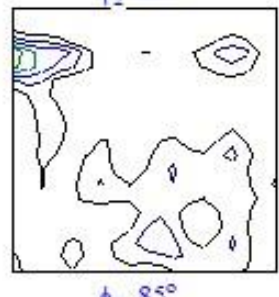

$\phi_{2} 85^{\circ}$

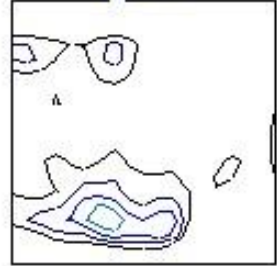

$\phi_{2} 15^{\circ}$

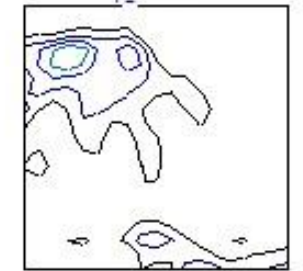

$\phi_{2} 46^{\circ}$

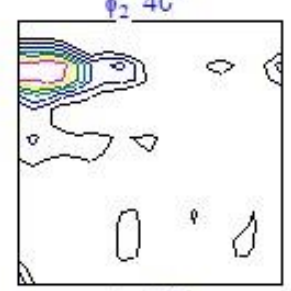

$\phi_{2} 65^{\circ}$

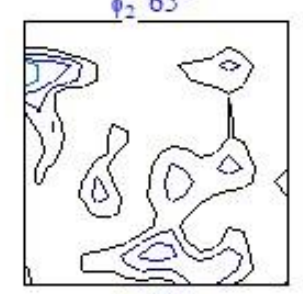

$\phi_{2} 9 \mathrm{C}^{\circ}$

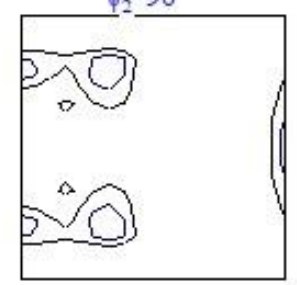

$\phi_{2} 20^{\circ}$

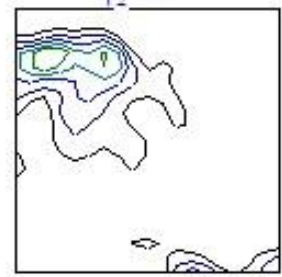

$\phi_{2} 45^{\circ}$

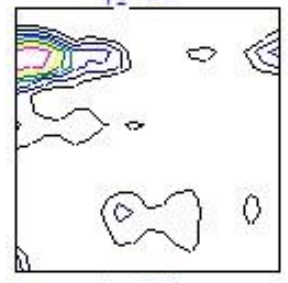

$\phi_{2} 70^{\circ}$
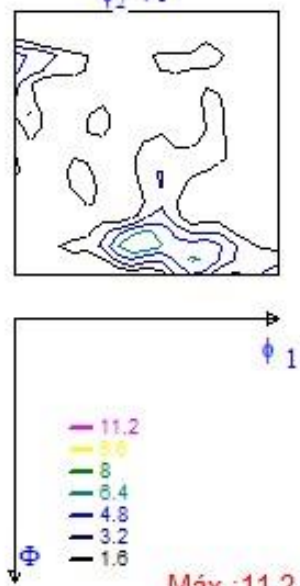

Figura 90 - FDO relativa à AA 7108 extrudada. A análise foi realizada sem preparação metalográfica prévia, de modo a avaliar a textura dos grãos periféricos e grosseiros

Com base nos resultados apresentados acerca da PCGZ, propõe-se o seguinte modelo para explicar a formação dessa região de grãos grosseiros (e que é ilustrada pelo desenho da Figura 91 mostrando a seção transversal do tarugo). Inicialmente, há um material formado por grãos de tamanho similar com precipitados dispersos (item A da figura mencionada). A coloração representa a temperatura associada ao material naquele momento (azul, temperatura ambiente, amarelo, material aquecido, e vermelho, material ainda mais aquecido em função da extrusão). Após aquecimento até temperaturas de solubilização, observa-se o aumento do tamanho dos grãos e a diminuição e redução do número de precipitados dispersos na matriz (item B). A extrusão a quente faz com que a periferia da seção transversal se aqueça mais que o interior em função do atrito com a ferramenta de extrusão, conforme mostra o item C. Nota-se que nesse ponto há a formação de subgrãos (representados por linhas pontilhadas), sendo que as maiores taxas de deformação associadas à periferia conduzem a formação de um maior número de subgrãos. O início da recristalização 
(dinâmica ou metadinâmica), indicado pelo item $\mathrm{D}$, mostra a formação de regiões com baixa densidade de defeitos, ou seja, os novos grãos, formando-se preferencialmente na região periférica. Isso porque o material presente na periferia se encontra com mais elevada energia de deformação (maior densidade de discordâncias) em relação à região central. Como a recristalização inicia-se na periferia, ela também é concluída primeiramente nessa região, conforme indica o item D. Enquanto isso, a recristalização ainda não foi concluída no centro do tarugo. Assim, enquanto ocorre a conclusão da formação de novos grãos na região central, os grãos periféricos crescem, impulsionados pela temperatura elevada associada ao processo de extrusão a quente (item E). Como resultado, obtém-se um material de microestrutura com grãos periféricos maiores em relação aos grãos localizados no centro (item F). O posterior resfriamento até a temperatura ambiente resulta no reaparecimento dos precipitados, conforma mostra o item $\mathrm{G}$. 

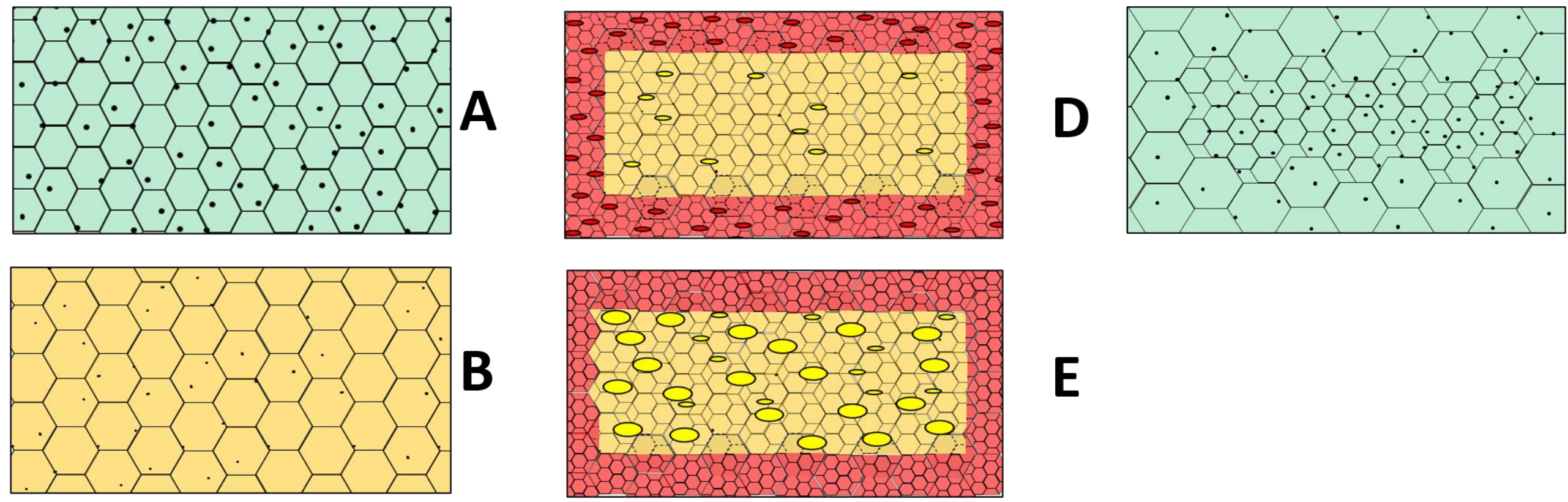

E
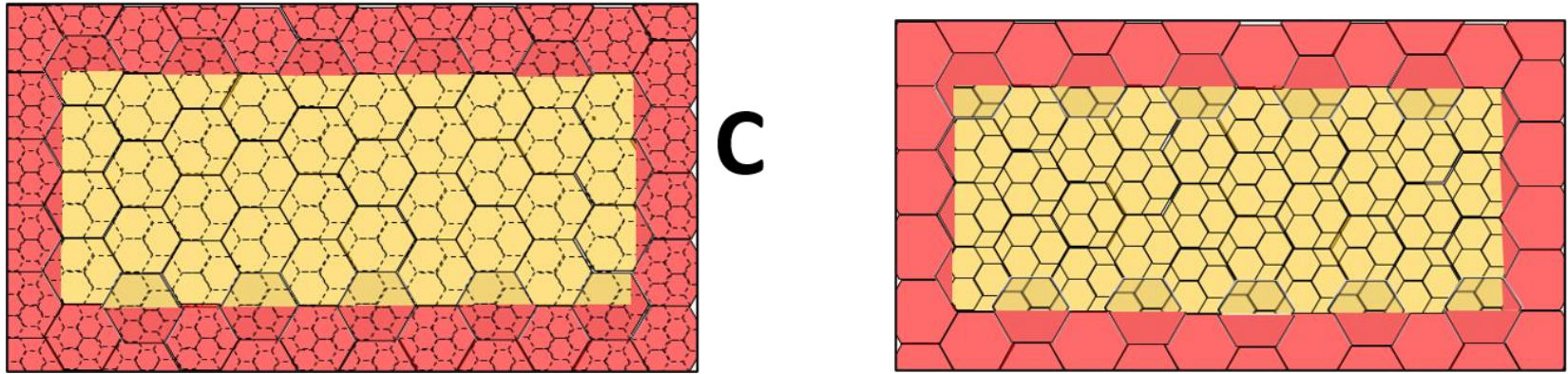

$\mathbf{F}$

Figura 91- Modelo proposto para descrever a formação da PCGZ nos materiais extrudados. Inicialmente, tem-se o material a temperatura ambiente (A) que é aquecido a temperaturas superiores à de solubilização $(B)$ e submetido à extrusão $(C)$. A periferia é submetida a maiores taxas de deformação e ocorre nessa região a formação de subgrãos menores e mais numerosos, o que por sua vez promove a recristalização durante o processamento mecânico a quente (C e D). A recristalização na periferia é concluída enquanto novos grãos ainda estão sendo formados no centro $(E)$. Os grãos recristalizados na região periférica crescem enquanto a recristalização e concluída na região central $(F)$. O material, após resfriamento, apresenta a microestrutura exibida esquematicamente em (G) 


\subsection{Caracterização microestrutural, medição de dureza Vickers e obtenção da macro e microtextura cristalográfica das amostras após processamento termomecânico.}

\subsubsection{Solubilização e envelhecimento das amostras}

A Tabela 10 mostra os valores médios de dureza e condutividade elétrica para a AA 7108 no estado inicial e após solubilização a $490^{\circ} \mathrm{C}$ por 5 horas. A queda de dureza após tratamento pode ser atribuída à dissolução dos precipitados (ou das zonas GP) de $M g Z n_{2}$, principal fase intermetálica responsável pelo endurecimento da liga.

Tabela 10 - Dureza e condutividade da AA 7108 no estado como recebido

\begin{tabular}{lcc}
\hline & Dureza (HV 0,1) & Condutividade (\%IACS) \\
Extrudada & $84,3 \pm 5,8$ & 38,9 \\
Após solubilização & $53,8 \pm 1,6$ & 41,5 \\
\hline
\end{tabular}

O aumento da condutividade elétrica, por outro lado, é considerado anômalo (conforme detalhado na revisão bibliográfica do presente trabalho). Sucintamente, sabe-se que elementos em solução sólida atuam como centros de espalhamento de elétrons de maneira mais eficiente do que precipitados. Dessa forma, seria esperado que a condutividade elétrica diminuísse com o tratamento de solubilização. No entanto, a formação das zonas GP (e não de precipitados coerentes ou semicoerentes) por meio do envelhecimento natural é a responsável pelo fenômeno observado, de forma que tais pequenos agrupamentos de átomos atuam de maneira mais efetiva do que átomos em solução sólida no aumento da resistência elétrica do material. O estudo conduzido por Waterloo e colaboradores [59] encontrou resultados de condutividade elétrica análogos aos do presente estudo.

Um mecanismo para explicar o comportamento anômalo da condutividade elétrica é apresentado a seguir. A Figura 92 apresenta microestruturas esquemáticas associadas às temperaturas T1, T2, T3 e T4 (relativas às curvas isócronas e isotérmicas mostradas na Figura 15). Observa-se que a microestrutura T2 é a que apresenta o maior número de obstáculos (nesse caso, zonas GP) à passagem de elétrons e, portanto, a maior resistividade elétrica. Já as microestruturas T3 e T4 já 
são compostas por precipitados intermetálicos que também atuam como obstáculos à passagem de portadores de carga, mas de maneira menos eficiente, o que explica a menor resistividade elétrica observada nesses casos.
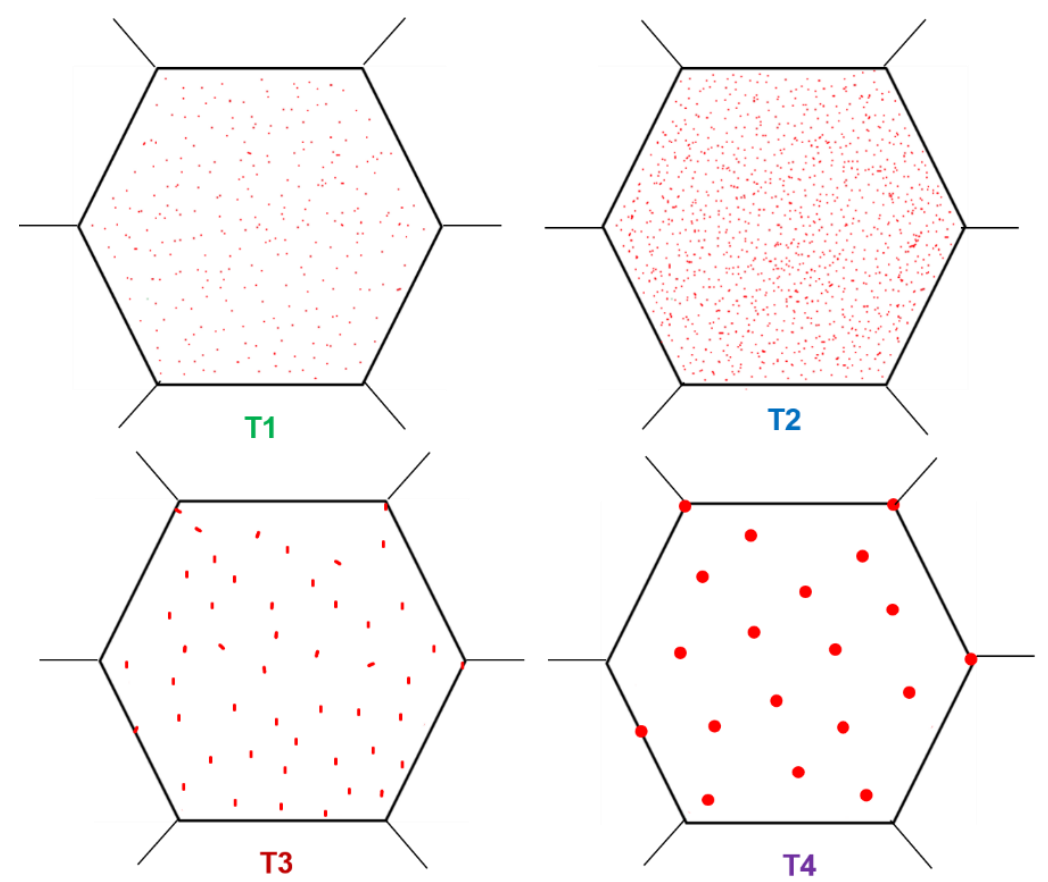

Figura 92 - Microestruturas esquemáticas associadas à precipitação de uma liga de alumínio endurecível por precipitação $(\mathrm{T} 1<\mathrm{T} 2<\mathrm{T} 3<\mathrm{T} 4)$

A Figura 93 mostra a evolução da dureza Vickers do material após solubilização quando deixado à temperatura ambiente e quando deixado em congelador convencional (a aproximadamente $-5^{\circ} \mathrm{C}$ ). Nota-se que a liga envelhece rapidamente quando deixada à temperatura ambiente, atingindo o patamar de dureza do estado inicial (aproximadamente $85 \mathrm{HV}$ ) em cerca de 4 dias. Por outro lado, nota-se que quando deixada em congelador convencional, a cinética de envelhecimento é retardada e o patamar de dureza atingido é menor em relação à amostra deixada à temperatura ambiente. Observa-se que, até o momento em que o patamar de dureza é atingido, os dados experimentais são bem descritos por uma função polinomial do segundo grau para ambos os casos. De maneira mais precisa, observa-se que o ajuste ao modelo quadrático funciona bem para intervalos de tempo compreendidos entre o tempo inicial e o tempo em que a dureza máxima é atingida. A partir desse ponto, os valores de dureza estabilizam-se ao redor do valor de pico e os dados experimentais passam a ser melhor descritos por funções sigmoides. 


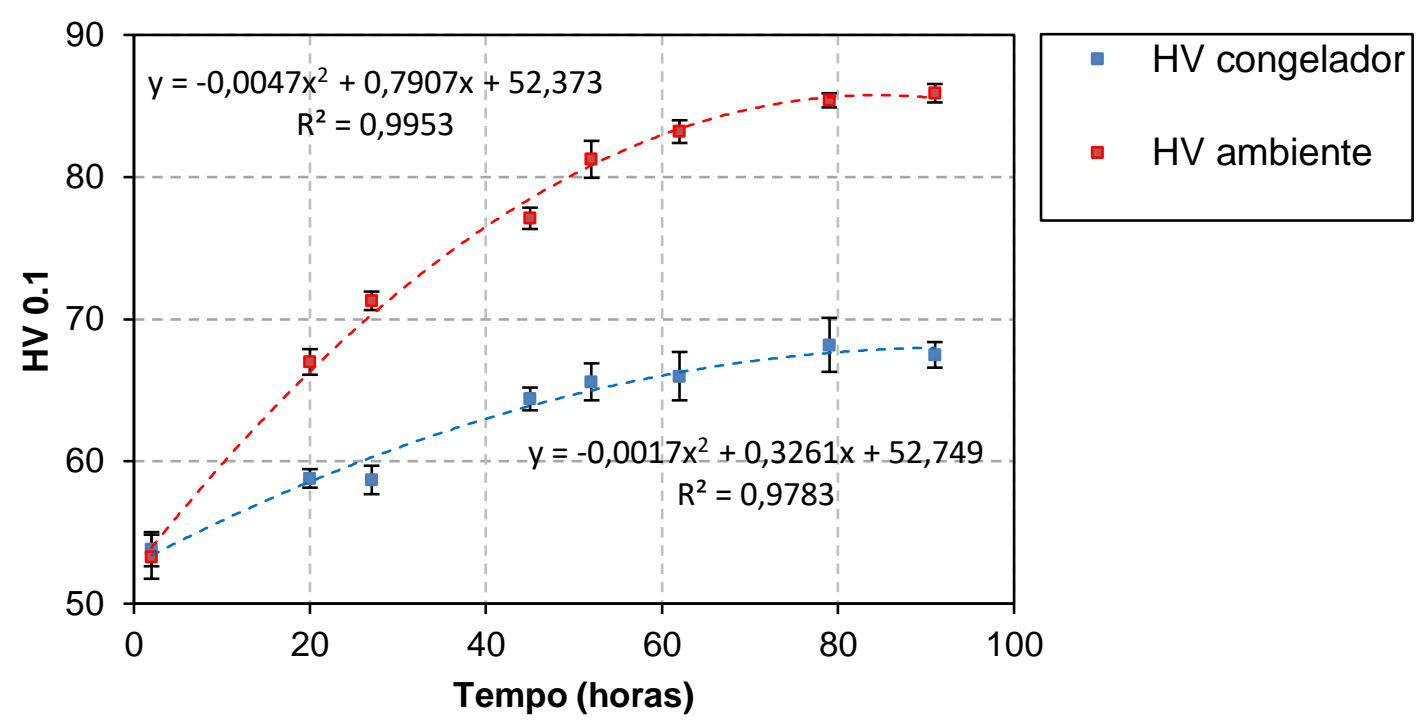

Figura 93 - Evolução da dureza a temperatura ambiente da amostra solubilizada a $490^{\circ} \mathrm{C}$ por 5 horas

A Figura 94 mostra a evolução da condutividade elétrica do material após solubilização, quando deixado à temperatura ambiente e em congelador comercial. A discussão e as conclusões são análogas às feitas no parágrafo anterior. Novamente, nota-se o bom ajuste entre os dados experimentais e funções polinomiais do segundo grau.

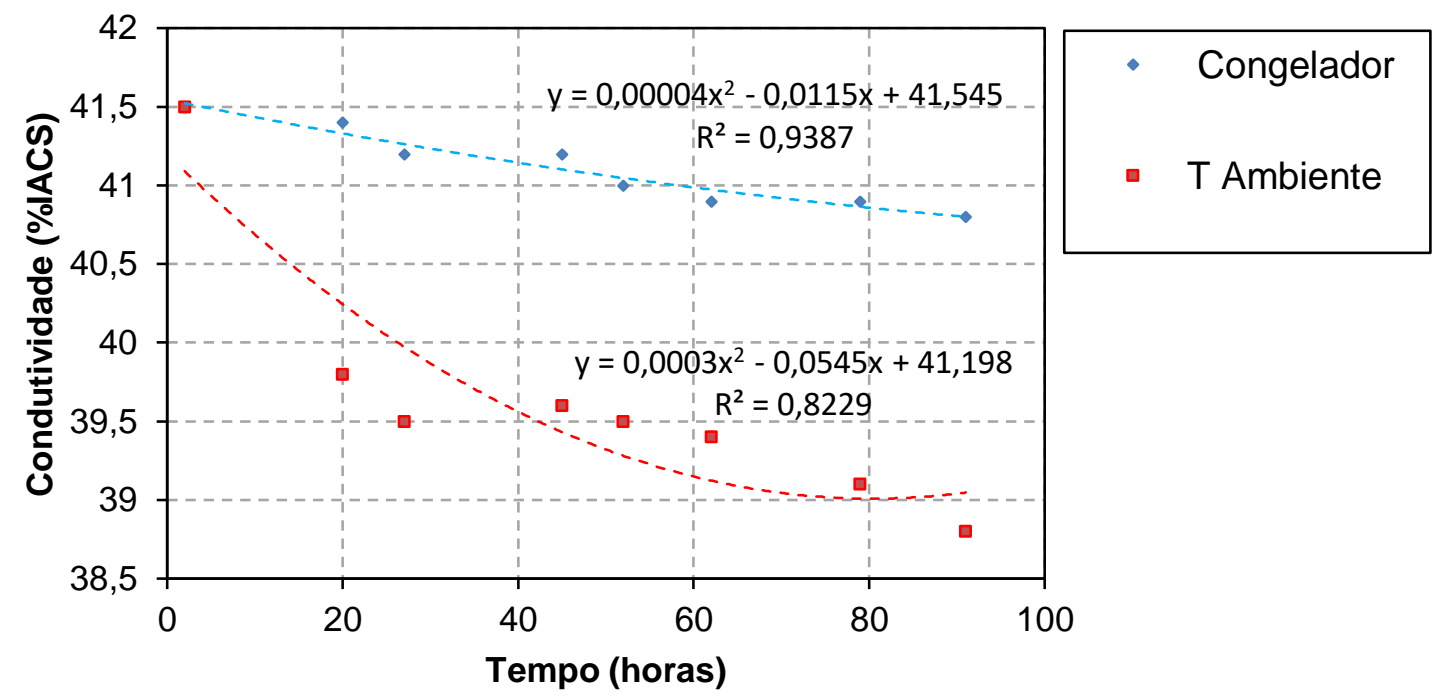

Figura 94 - Evolução da condutividade elétrica a temperatura ambiente da amostra solubilizada a $490^{\circ} \mathrm{C}$ por 5 horas

A Figura 95 mostra variação da condutividade elétrica com a dureza para a AA 7108 solubilizada e envelhecida a temperatura ambiente. Curvas desse tipo podem ser úteis para avaliar a resistência mecânica de um dado material envelhecido sem recorrer a ensaios de dureza que danifiquem sua superfície por meio de endentações. 
Tariq e colaboradores [124] mostraram que para o envelhecimento artificial de ligas de alumínio da série 2xxx, existe uma relação polinomial de segundo grau entre dureza e condutividade elétrica. A relação também aparenta estar presente no caso da AA 7108 envelhecida a temperatura ambiente, conforme mostra o índice de correlação $R^{2} \cong 0,87$.

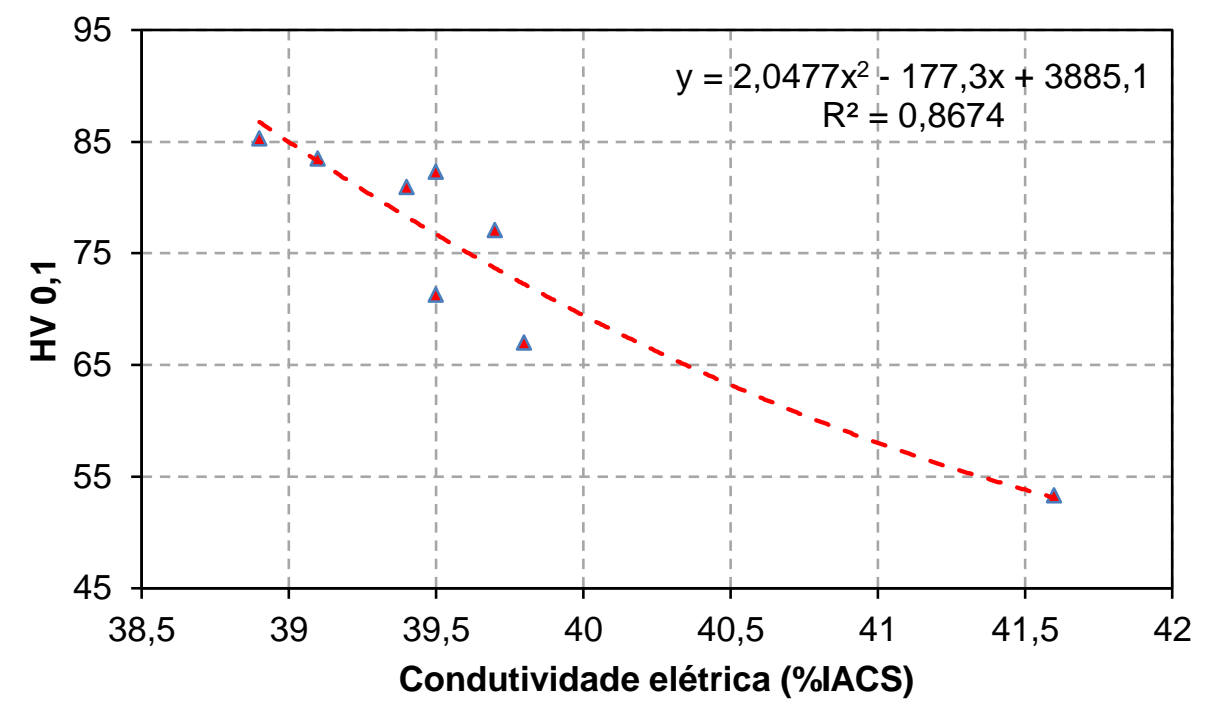

Figura 95 - Variação da dureza em função da condutividade elétrica. A linha vermelha mostra a função de segundo grau que melhor se ajusta ao conjunto de dados.

Uma das amostras, imediatamente após solubilização, foi envelhecida a $120^{\circ} \mathrm{C}$ por 24 horas (T6), e as medidas de dureza e condutividade são apresentadas na Tabela 11. Os resultados (aumento de dureza e condutividade) ajudam a reforçar a possibilidade de que a presença de zonas GP atua de maneira mais eficiente do que os átomos em solução sólida no aumento da resistência elétrica.

Tabela 11 - Dureza e condutividade da AA 7108 após tratamento de solubilização $\left(490^{\circ} \mathrm{C}\right.$ por 5 horas $)$ seguido de envelhecimento artificial $\left(120^{\circ} \mathrm{C} / 24\right.$ horas - T6);

\begin{tabular}{cc}
\hline Dureza (HV 0,1) & Condutividade (\%IACS) \\
\hline $108,2 \pm 2,4$ & 42,6 \\
\hline
\end{tabular}

\subsubsection{Laminação das amostras solubilizadas}

A Tabela 12 mostra a evolução da espessura das tiras durante o processo de laminação. A redução por passe foi, aproximadamente, de $0,4 \mathrm{~mm}$ para as atiras denominadas "A" e de 0,2 mm para as tiras denominadas "B". Também é mostrado o fator $\Delta$ calculado para cada etapa, além da deformação (verdadeira) acumulada. Os 
cálculos foram feitos em função do diâmetro dos rolos de laminação utilizados (50 $\mathrm{mm}$ ). Em destaque (fonte vermelha), são mostrados os valores relativos às tiras selecionadas para prosseguimento da parte experimental. 
Tabela 12 - Reduções de espessura das amostras em relação ao número de passes de laminação

\begin{tabular}{|c|c|c|c|c|c|c|c|c|}
\hline \multicolumn{5}{|c|}{ Tira tipo A } & \multicolumn{4}{|c|}{ Tira tipo B } \\
\hline Passe & h0 & hf & $\Delta$ & $\begin{array}{c}\text { Deformação } \\
\text { (verdadeira) } \\
\text { acumulada }\end{array}$ & h0 & hf & $\Delta$ & $\begin{array}{c}\text { Deformação } \\
\text { (verdadeira) } \\
\text { acumulada }\end{array}$ \\
\hline 1 & 6,86 & 6,48 & 0,73 & 0,06 & 6,86 & 6,7 & 0,74 & 0,03 \\
\hline 2 & 6,48 & 6,14 & 0,58 & 0,11 & 6,65 & 6,5 & 0,72 & 0,06 \\
\hline 3 & 6,14 & 5,75 & 0,56 & 0,18 & 6,49 & 6,3 & 0,72 & 0,08 \\
\hline 4 & 5,75 & 5,35 & 0,54 & 0,25 & 6,33 & 6,1 & 0,71 & 0,11 \\
\hline 5 & 5,35 & 4,97 & 0,52 & 0,32 & 6,14 & 6 & 0,70 & 0,14 \\
\hline 6 & 4,97 & 4,55 & 0,50 & 0,41 & 5,95 & 5,8 & 0,68 & 0,18 \\
\hline 7 & 4,55 & 4,13 & 0,48 & 0,51 & 5,75 & 5,5 & 0,67 & 0,21 \\
\hline 8 & 4,13 & 3,7 & 0,46 & 0,62 & 5,54 & 5,4 & 0,66 & 0,25 \\
\hline 9 & 3,7 & 3,3 & 0,43 & 0,73 & 5,35 & 5,2 & 0,65 & 0,29 \\
\hline 10 & 3,3 & 2,9 & 0,41 & 0,86 & 5,15 & 5 & 0,64 & 0,32 \\
\hline 11 & 2,9 & 2,5 & 0,38 & 1,01 & 4,96 & 4,8 & 0,62 & 0,37 \\
\hline 12 & & & & & 4,76 & 4,6 & 0,61 & 0,41 \\
\hline 13 & & & & & 4,55 & 4,3 & 0,59 & 0,47 \\
\hline 14 & & & & & 4,3 & 4,1 & 0,58 & 0,51 \\
\hline 15 & & & & & 4,13 & 3,9 & 0,57 & 0,56 \\
\hline 16 & & & & & 3,93 & 3,7 & 0,55 & 0,62 \\
\hline 17 & & & & & 3,7 & 3,5 & 0,54 & 0,67 \\
\hline 18 & & & & & 3,5 & 3,3 & 0,52 & 0,73 \\
\hline 19 & & & & & 3,3 & 3,1 & 0,51 & 0,79 \\
\hline 20 & & & & & 3,1 & 2,9 & 0,49 & 0,86 \\
\hline 21 & & & & & 2,9 & 2,7 & 0,47 & 0,93 \\
\hline 22 & & & & & 2,7 & 2,5 & 0,46 & 1,01 \\
\hline
\end{tabular}

A Figura 96 indica graficamente as etapas de laminação realizadas, passo a passo, e a deformação real acumulada em cada passe. Na figura também são indicadas as amostras selecionadas para análise, as quais convencionou-se chamar A, B, 30 ou 60. A nomenclatura se deu em função da redução em espessura calculada para cada uma das tiras. Dessa forma, por exemplo, a amostra denominada A 30 foi processada via 6 passes e sofreu uma redução em espessura de $33,7 \%$, o que, para a presente análise, corresponde à deformação real de 0,41. As amostras de índice 60 sofreram redução em espessura de $63,6 \%$. A nomenclatura dada às tiras será posteriormente retomada na forma de tabela. 
Tipo A

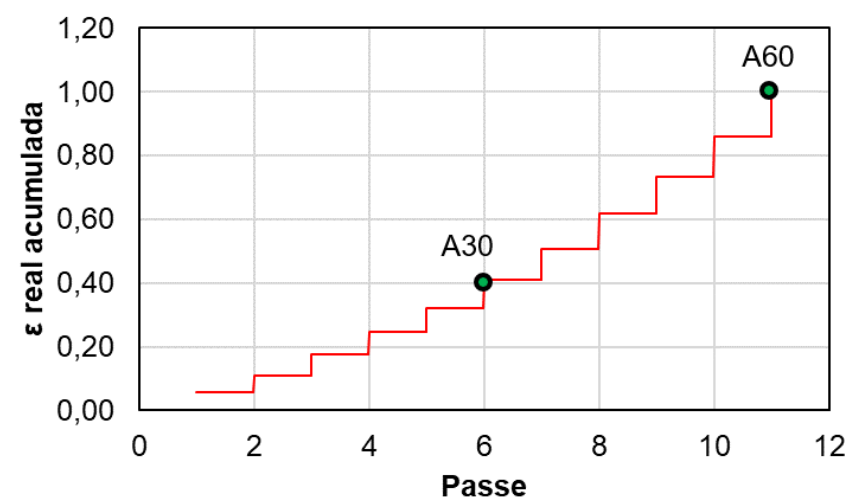

Tipo B

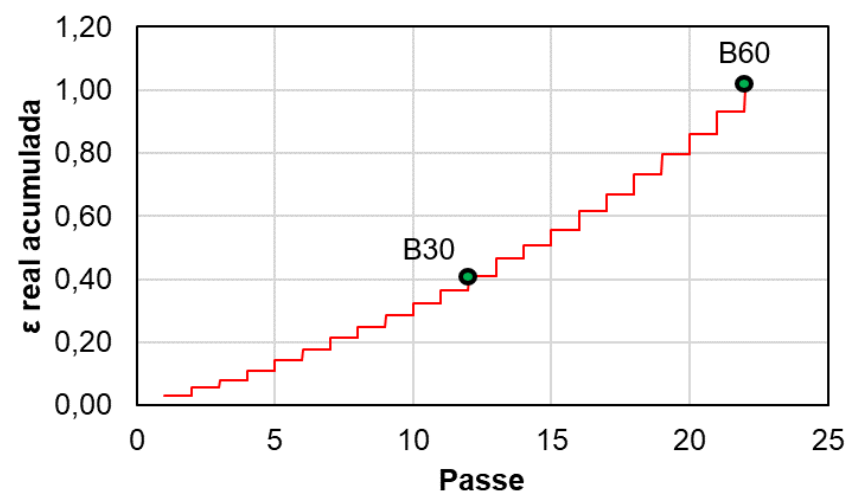

Figura 96 - Representação gráfica da deformação real acumulada em função do número de passes realizados. As amostras selecionadas para análise estão indicadas em cada um dos gráficos.

A Figura 97 mostra as micrografias obtidas por microscopia óptica de luz polarizada da superfície de laminação das amostras processadas. Em cada uma das micrografias é indicado o nome adotado (A, B, 30 e 60) e o sentido de laminação. Nota-se (qualitativamente) que os grãos das amostras processadas com um menor número de passes $(B)$ são maiores e de coloração mais bem definida (indicando que a diferença de orientação entre os subgrãos dentro de um dado grão é pequena). As observações são corroboradas pela literatura que indica que a de multiplicação de discordâncias (os defeitos que compõe os subgrãos) é potencializada pelo maior grau de deformação. Por outro lado, como um material de elevada EDE, o alumínio e suas 
ligas podem experimentar a formação de células (rearranjos de discordâncias de menor energia associada) mediante a menores velocidades de deformação $[20,36]$.
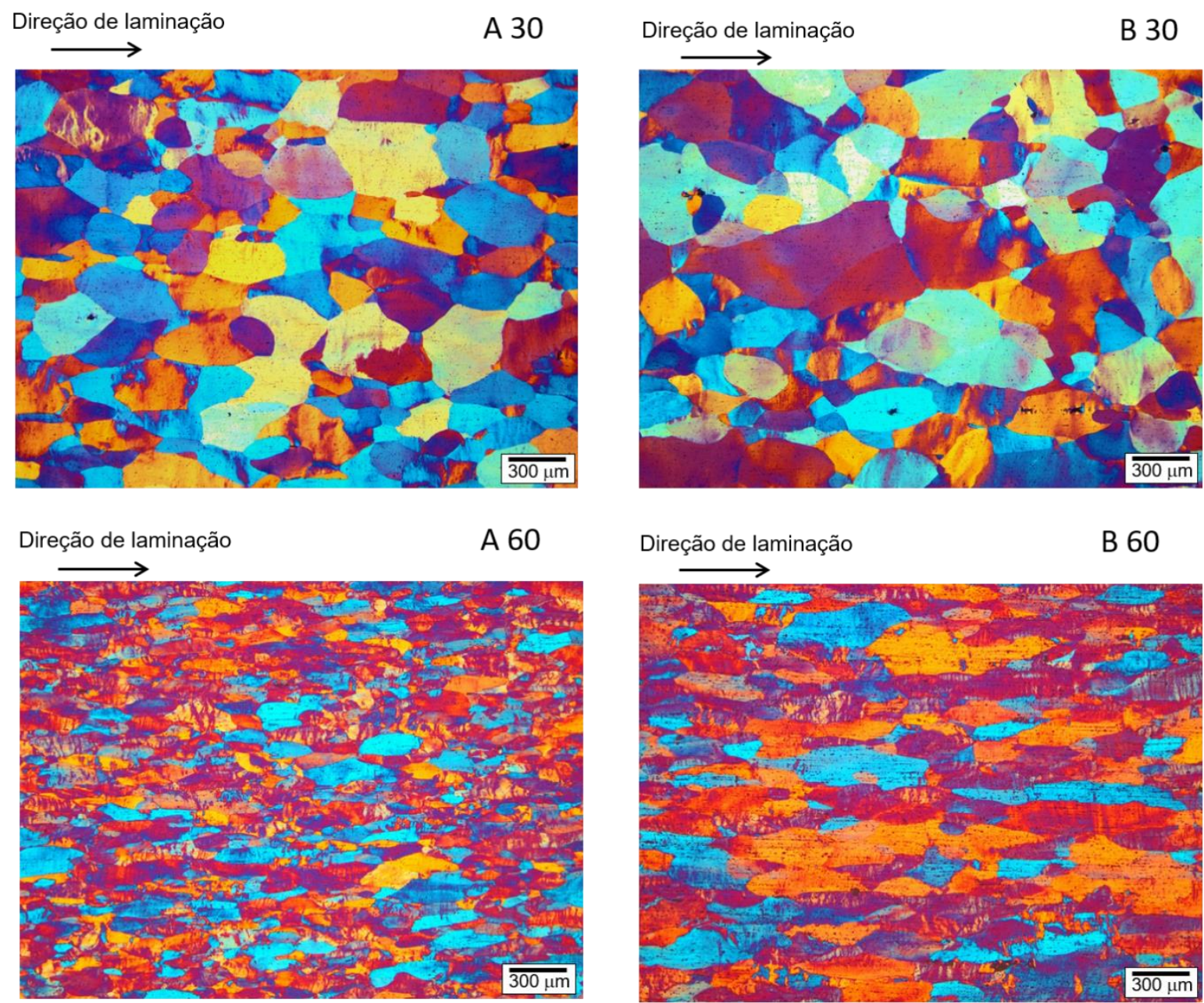

Figura 97 - Micrografias ópticas obtidas com auxílio de luz polarizada para as amostras deformadas por laminação. Acima de cada imagem é indicada o sentido de laminação e a especificação (simbologia adotada nesse trabalho) da amostra em relação ao grau de redução e ao número de passes

A Tabela 13 mostra os valores de dureza Vickers e condutividade elétrica medidas imediatamente após a etapa de laminação das quatro tiras. Nota-se que o número de passes influencia a dureza de maneira mais significativa para a o menor grau de redução. É possível explicar o maior nível de dureza da amostra B $30 \mathrm{em}$ relação à $A 30 \mathrm{com}$ base no diferente número de passes adotados. Como a amostra $\mathrm{B}$ foi deformada de maneira mais lenta (com mais passes para atingir o mesmo grau de redução), houve mais tempo para ocorrência da movimentação e rearranjo de discordâncias (possivelmente em arranjos celulares), o que resultou na queda de dureza observada. Por outro lado, nota-se que para o grau de deformação mais elevado (63,6\%), a diferença de dureza entre as tiras A e B é pouco significativa. É 
possível que, em função do maior número de passes, a continuação da deformação da tira B gere uma densidade de discordâncias tão elevada de forma que a formação das novas células de discordância seja inviável. O resultado é, portanto, o aumento da dureza [71].

Por outro lado, nota-se uma queda muito sensível na condutividade elétrica em todos os quatro casos. O encruamento, portanto, possui pouca influência na variação condutividade elétrica da AA 7108 deformada.

Tabela 13 - Medidas de dureza e condutividade elétrica medidas imediatamente após laminação a frio das amostras

\begin{tabular}{ccccc}
\hline Denominação & Redução & $\begin{array}{c}\text { Número de } \\
\text { passes }\end{array}$ & $\begin{array}{c}\text { Dureza } \\
\text { Vickers }\end{array}$ & $\begin{array}{c}\text { Condutividade(\% } \\
\text { IACS) }\end{array}$ \\
\hline A 30 & $33,7 \%$ & 6 & $90,8 \pm 3,1$ & 41 \\
B 30 & $33,7 \%$ & 12 & $84,2 \pm 3,5$ & 41,3 \\
A 60 & $63,6 \%$ & 11 & $107,5 \pm 2,3$ & 40,8 \\
B 60 & $63,6 \%$ & 22 & $105,3 \pm 2,8$ & 40,9 \\
\hline
\end{tabular}

As tiras deformadas foram mantidas em congelador comercial (aproximadamente a $-5^{\circ} \mathrm{C}$ ) com o objetivo de minimizar a ocorrência de envelhecimento por formação de zonas GP e de precipitados. Medidas de dureza Vickers foram tomadas com o passar do tempo. Os resultados são exibidos na Figura 98. Observa-se que o aumento de dureza em função do envelhecimento é retardado em relação às amostras que foram solubilizadas, mas não deformadas. É possível que a estrutura de discordâncias presente nas amostras deformadas interaja com os átomos de soluto impedindo seu agrupamento. 


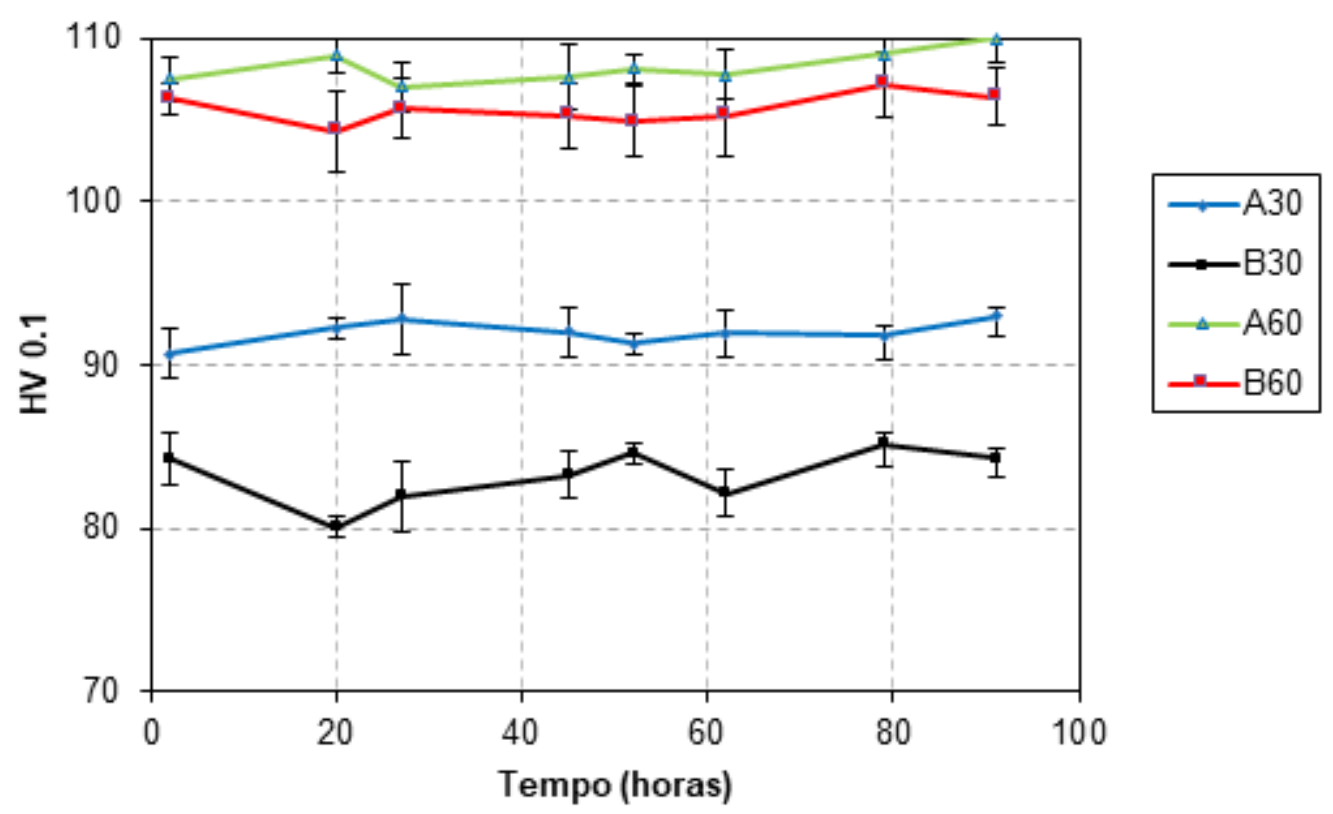

Figura 98 - Variação da dureza com o tempo das amostras laminadas e mantidas em congelador comercial

A título de comparação, analisou-se o envelhecimento das amostras laminadas e somente solubilizadas, por meio de medidas de dureza, em temperatura ambiente (cerca de $25^{\circ} \mathrm{C}$ ), conforme mostrado na Figura 99. Enquanto em congelador não foram observadas grandes variações na dureza ao longo do tempo, em temperatura ambiente, notou-se uma variação de aproximadamente $30 \mathrm{HV}$ entre o momento inicial e o início da uma estabilização do nível de dureza, indicando a forte influência da temperatura no envelhecimento dessa liga. Observa-se que o aumento de dureza causado em função do envelhecimento é análogo quando comparam-se as amostras deformadas (A60 e B60) e sem deformação (somente solubilizada). A diferença entre os níveis de dureza entre as tiras laminadas e extrudadas pode ser atribuída, conforme indicado na Figura 99, exclusivamente ao encruamento, simbolizado por $\sigma$ deformação. 


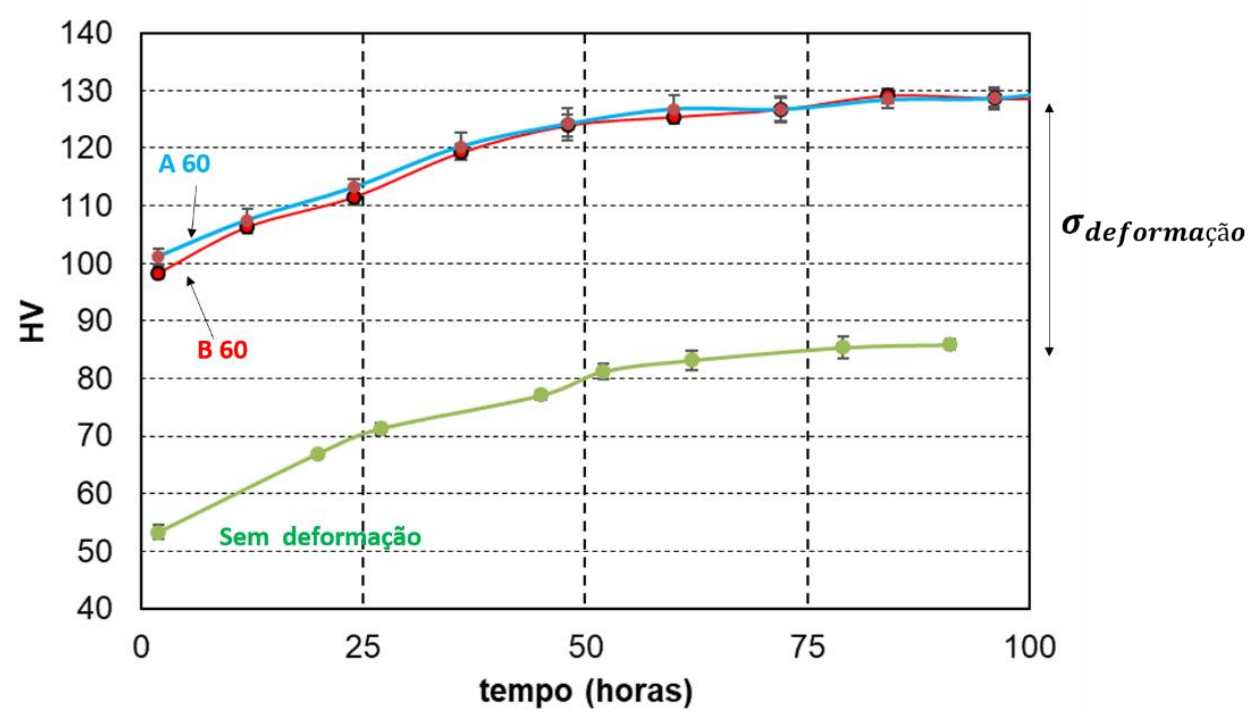

Figura 99 - Variação da dureza com o tempo das amostras laminadas e mantidas em temperatura ambiente. A amostra somente solubilizada também foi estudada a título de comparação

Como o aumento de dureza pode ser atribuído à formação das zonas GP, é possível utilizar as medidas de dureza para avaliar a cinética desse fenômeno em temperatura ambiente. Para tal, utiliza-se um modelo já aplicado em outros estudos envolvendo ligas de alumínio $[85,87]$ e transformações de fase dado por:

$$
X=\frac{H_{t}-H_{0}}{H_{\max }-H_{0}}
$$

Onde $X$ é a fração transformada, $H_{t}$ é a dureza em um certo intervalo de tempo t, $H_{0}$ é a dureza medida logo após a solubilização ou laminação (um parâmetro inicial) e $H_{\max }$ é a dureza de patamar atingida após certo intervalo de tempo e que se mantém estável desse momento em diante. A Figura 100 exibe a fração transformada em função do tempo para amostras deixadas a temperatura ambiente (cerca de $25^{\circ} \mathrm{C}$ ). A distribuição dos pontos mostra um comportamento similar para as três situações analisadas (A60, B60 e amostra somente solubilizada) indicando pouca influência do nível de deformação na velocidade de envelhecimento natural observada para a AA 7108. Cabe ressaltar que o comportamento em questão foi observado para temperatura ambiente. Caso fosse realizado um envelhecimento artificial, a formação de precipitados e a ocorrência de recristalização (e/ou recuperação) possivelmente influenciar-se-iam mutuamente [71] (Vide Figura 32). 


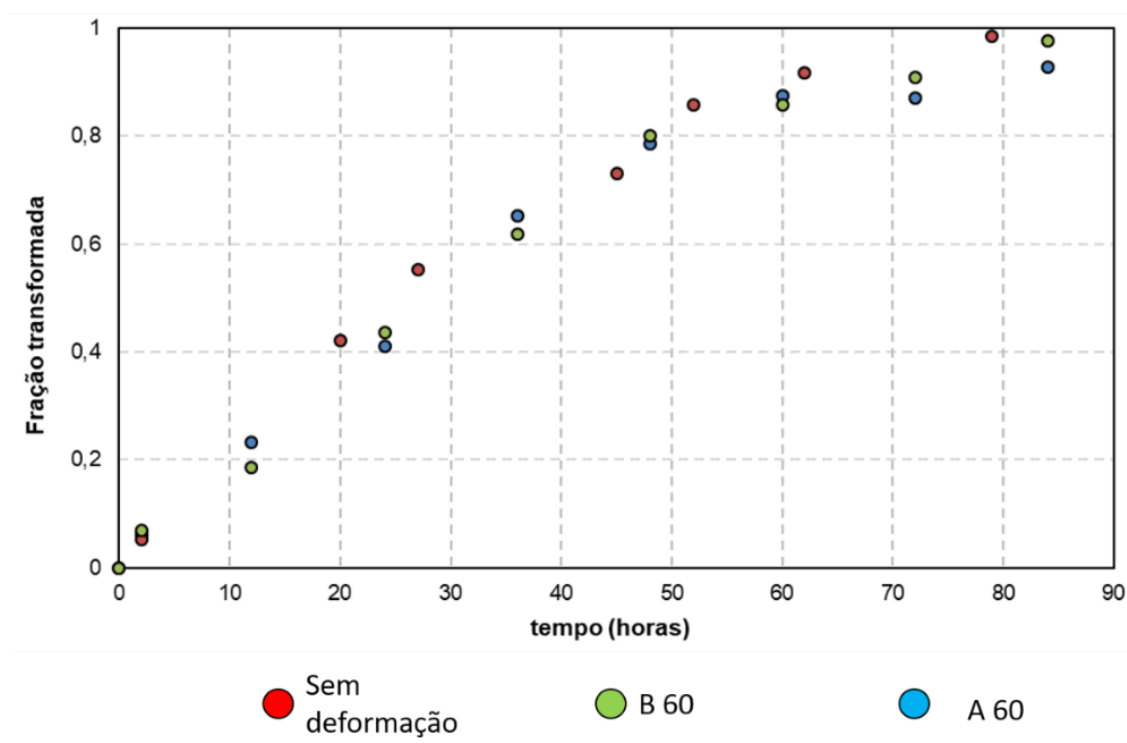

Figura 100 - Gráfico da fração transformada em função do tempo para as amostras solubilizadas, A60 e B60

Por fim, os dados relacionados à fração transformada foram aplicados ao consolidado modelo JMAK para descrever a cinética de transformações de fase, uma vez que a utlização do modelo de Johnson-Mehl-Avarami-Kolmogorov (Equação 24) para descrever o fenômeno de precipitação em ligas de alumínio constitui prática recorrente [124,125]. A equação, em sua forma linear, é dada por:

$$
\ln \left[\ln \frac{1}{(1-X)}\right]=\ln A+n \ln t
$$

Onde A e n são constantes que podem ser determinadas experimentalmente e t é o tempo decorrido. Os resultados obtidos pela correlação dos dados com a equação são apresentados no gráfico da Figura 101. O ajuste do modelo aos dados experimentais apresentou coeficiente de correção $(R)$ maior que 0,9 para todos os três casos estudados, indicando boa relação entre a equação e os valores obtidos experimentalmente. Nota-se, entretanto, que a diferença entre os coeficientes $n$ é muito pequena para os três casos analisados. Dessa forma, é possível afirmar que, para a análise realizada em temperatura ambiente, o grau de encruamento influencia pouco a velocidade de formação de zonas GP e precipitados para a liga estudada.

O expoente "n" da forma não-linear da equação de Avrami está associado ao mecanismo da transformação de fase. Um valor próximo a 1, conforme o encontrado para o envelhecimento natural das amostras analisadas, indica que a nucleação das 
partículas de segunda fase ocorre no volume e o crescimento das regiões transformadas ocorre ao longo de uma única dimensão [127].

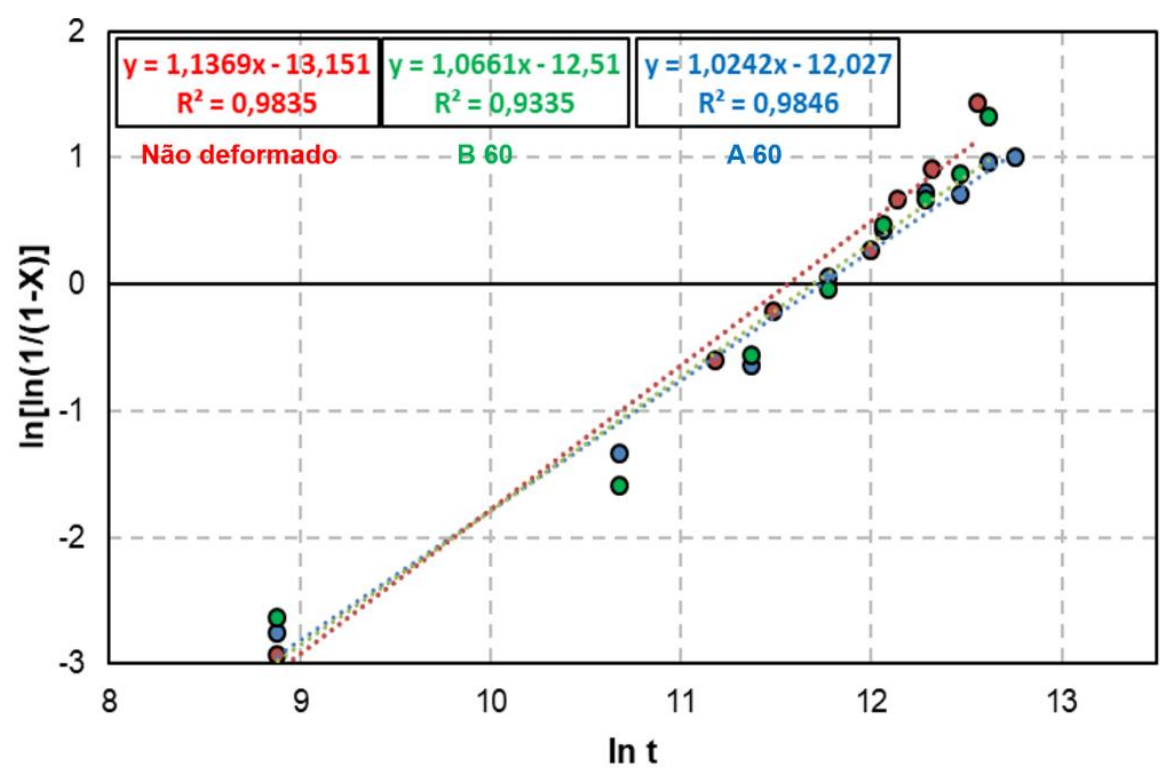

Figura 101 - Ajuste dos dados experimentais de dureza Vickers das amostras A60, B60 e somente solubilizada ao modelo JMAK

Outra equação empírica, proposta em 1938 por Austin e Rickett [128], também pode ser utilizada para analisar a cinética de envelhecimento. Embora esse modelo seja originalmente empregado para o estudo da cinética de decomposição da austenita em ligas ferrosas, ele também tem sido aplicado para avaliar a velocidade de precipitação de fases intermetálicas [30]. A equação em questão, para uma dada temperatura fixa, é dada por:

$$
\log \left(\frac{P}{100-P}\right)=k \cdot \log t+C
$$

Onde "P" é a fração transformada em termos percentuais, " $\mathrm{t}$ " é o intervalo de tempo decorrido desde o início da transformação e " $\mathrm{k}$ " e "C" são constantes a serem determinadas. A Figura 102 exibe os resultados do ajuste dos dados experimentais ao modelo de Austin-Rickett. Nota-se que embora os valores de $\mathrm{R}^{2}$ sejam, para todos os casos analisados, maiores que 0,8 (indicando razoável correlação), eles ainda são inferiores aos valores de $R^{2}$ associados ao ajuste em relação ao modelo JMAK. A Tabela 14 compara os valores entre os coeficientes de correlação para todas as situações avaliadas e permite a constatação do melhor ajuste dos dados experimentais ao modelo JMAK. 


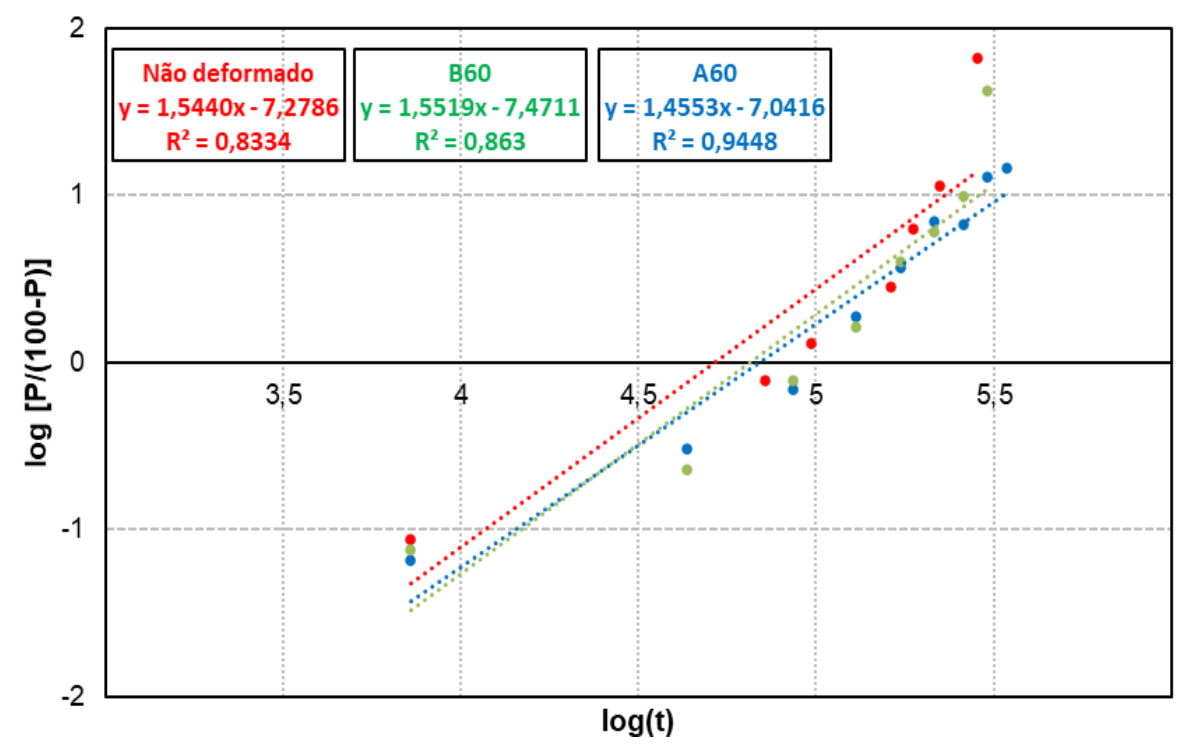

Figura 102 - Ajuste dos dados experimentais de dureza Vickers das amostras A60, B60 e somente solubilizada ao modelo Austin-Rickett

Tabela 14 - Comparativo entre os valores de $\mathrm{R}^{2}$ associados ao ajuste dos dados experimentais aos modelos JMAK e Austin-Rickett

\begin{tabular}{ccc}
\cline { 2 - 3 } Amostra & \multicolumn{2}{c}{$\mathbf{R}^{\mathbf{2}}$} \\
\hline JMAK & Austin-Rickett \\
\hline A60 & 0,9846 & 0,9448 \\
B60 & 0,9335 & 0,8630 \\
\hline
\end{tabular}

\subsubsection{Análise da textura cristalográfica das tiras laminadas}

Análises de textura cristalográfica via difração de raios $\mathrm{X}$ foram realizadas para amostras obtidas das tiras laminadas. Inicialmente, apresenta-se as figuras de polo a partir das quais as FDOs foram obtidas. O grau de simetria observado nas figuras de polo indica a validade do método adotado, uma vez que a ferramenta computacional adotada (PAT) impõe simetria às situações analisadas, ainda que essa seja baixa. A Figura 103 mostra as figuras da polo associadas às amostras A30, A 60, B30 e B60. 
A 30

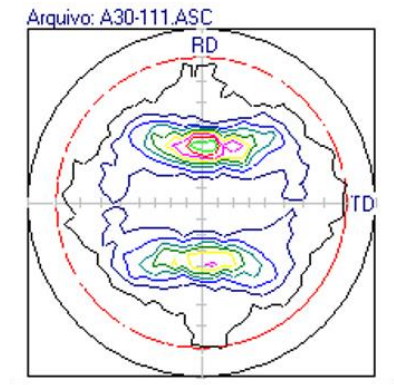

Arquivo: A.60-111.ASC

A 60

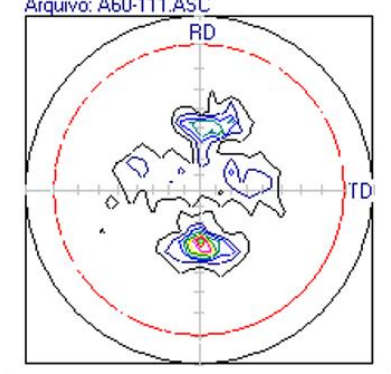

B 30

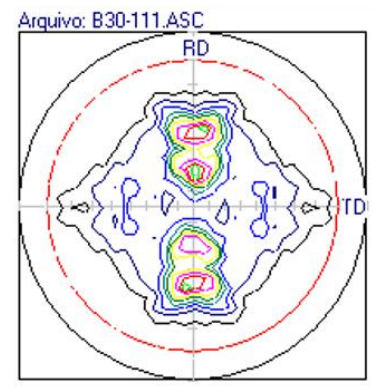

B 60

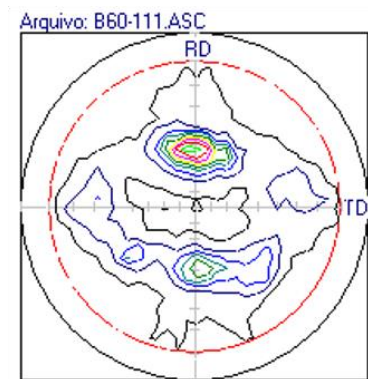

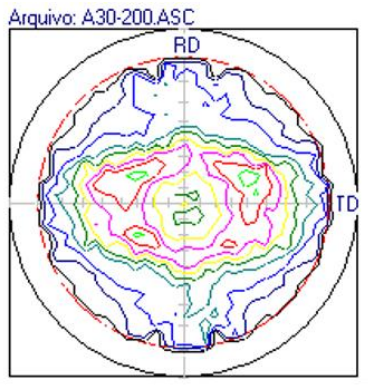
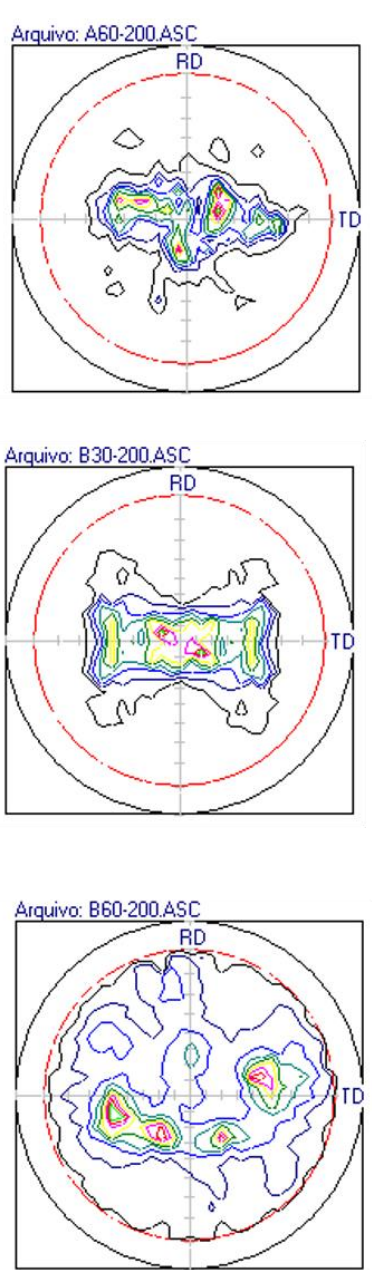
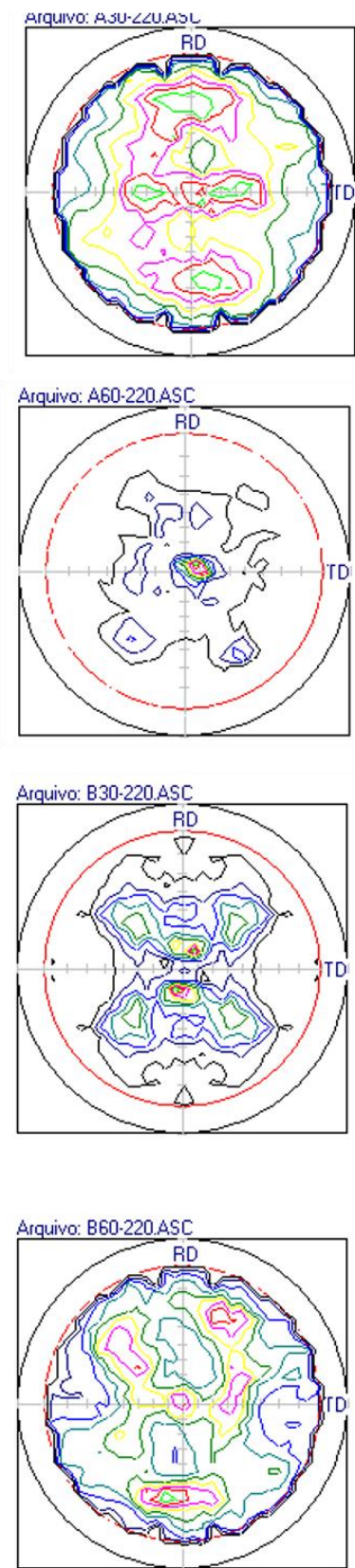

Figura 103 - Figuras de polo associadas às amostras laminadas. A indicação à esquerda mostra de qual tira referem-se as figuras de polo.

A Figura 104 mostra seções de $\varphi_{2}=0$ da função densidade de orientações da amostra A30. São observadas componentes do tipo Goss $\{110\}<001>$ (mais forte) e Latão $\{011\}<211>$ (mais fraca), além da componente Cubo $\{001\}<110>$, remanescente do estado anterior (totalmente recristalizado). 

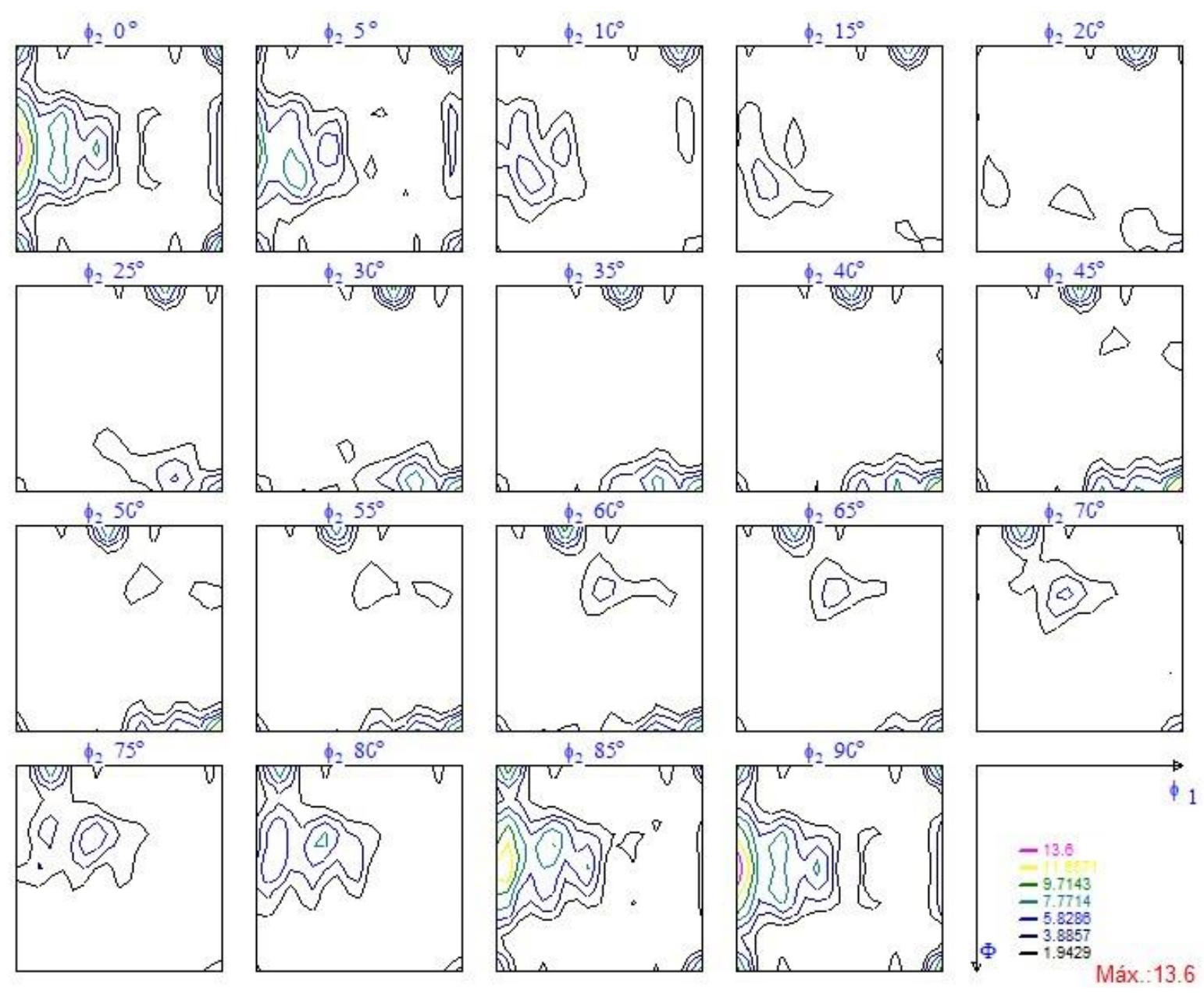

Figura 104 - FDO relativa à superfície de laminação da amostra A 30

Em relação à amostra B30 (cuja função densidade de orientações é apresentada na Figura 105, nota-se somente a presença da componente Goss. A textura do tipo cubo remanescente é menos intensa e a componente latão não foi identificada na análise. Aparentemente, a deformação por meio de um maior número de passes é mais eficaz na "remoção" da textura de recristalização previamente existente. Possivelmente, os passes menores permitem que os planos atômicos tenham mais tempo para deslizar uns sobre os outros de modo a acomodar a deformação e alterar a orientação final dos grãos de maneira mais eficiente. 

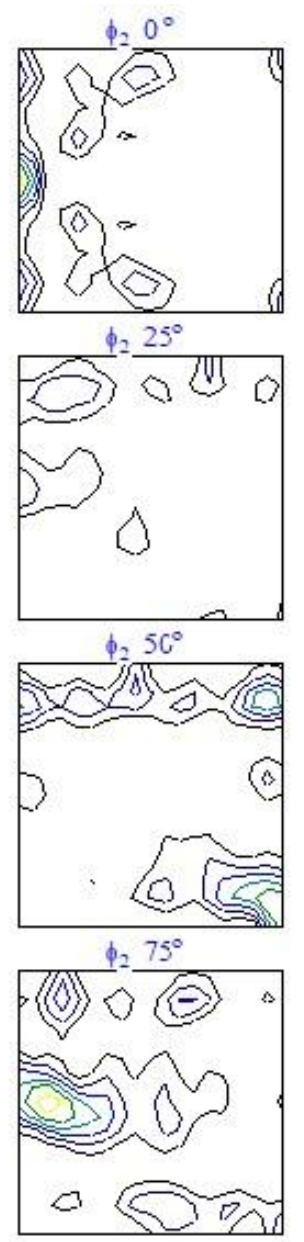

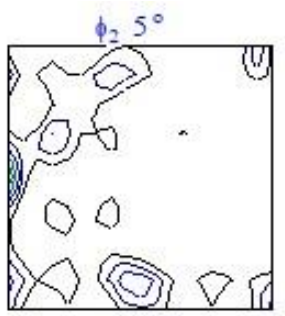

$\phi_{2} 3 c^{\circ}$

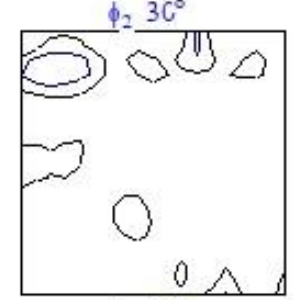

$\phi_{2} 55^{\circ}$

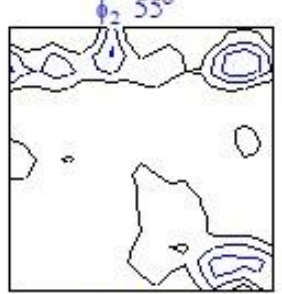

$\phi_{2} s 0^{\circ}$

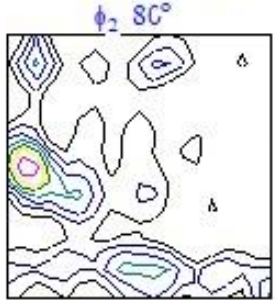

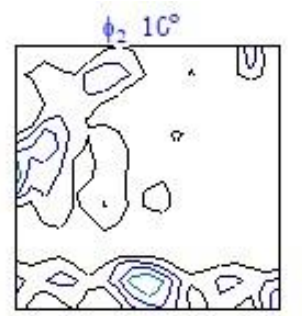

$\phi_{2} 35^{\circ}$

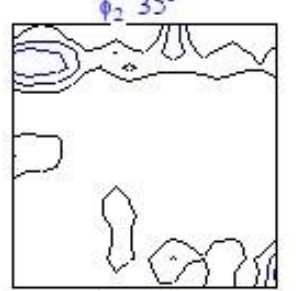

$\phi_{2} 66^{\circ}$

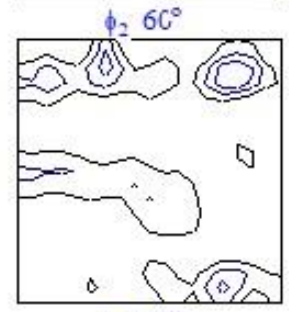

$\phi_{2} 85^{\circ}$

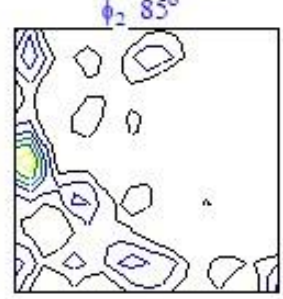

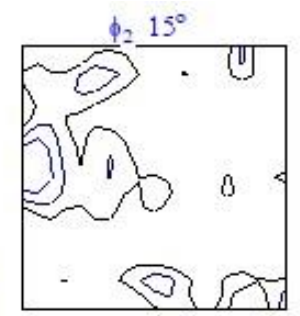

$\phi_{2} 4 c^{\circ}$

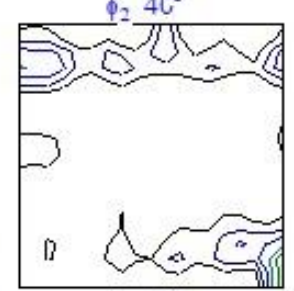

$\phi_{2} 65^{\circ}$

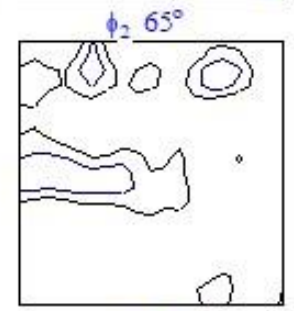

$\phi_{2} 9 \mathrm{C}^{\circ}$

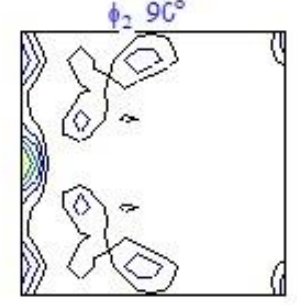

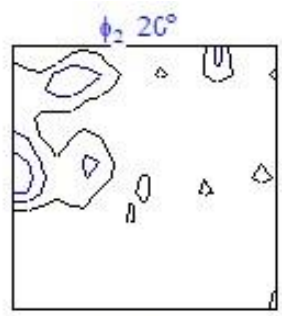

$\phi_{2} 45^{\circ}$

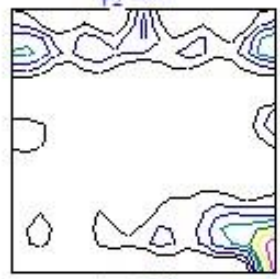

$\phi_{2} 7 \mathrm{C}^{\circ}$
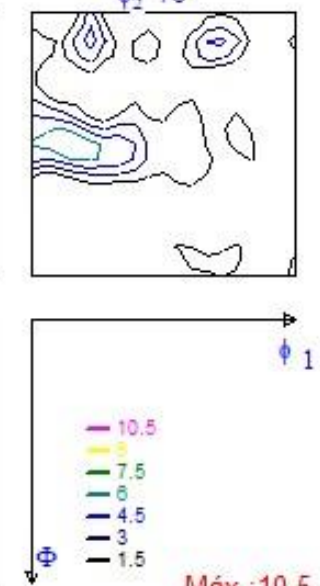

Figura 105 - FDO relativa à superfície de laminação da amostra B 30

A Figura 106 mostra a FDO relativa à amostra A 60. A componente do tipo Cubo, presente nas análises anteriores, não foi identificada. A amostra apresentou uma intensa componente Goss $(\mathrm{f}(\mathrm{g})=21,7)$ em relação às amostras deformadas com $33,7 \%$ em redução de espessura. É possível identificar também a presença da componente do tipo Latão, de menor intensidade. 


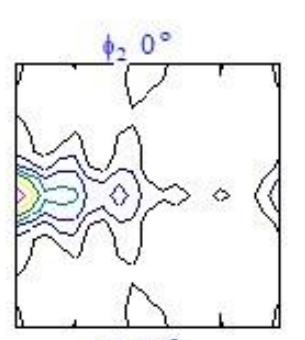

$\phi_{2} 25^{\circ}$

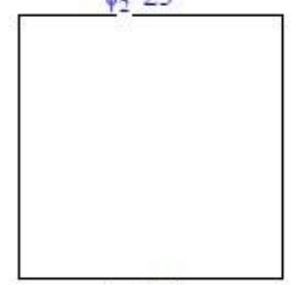

$\phi_{2} 56^{\circ}$
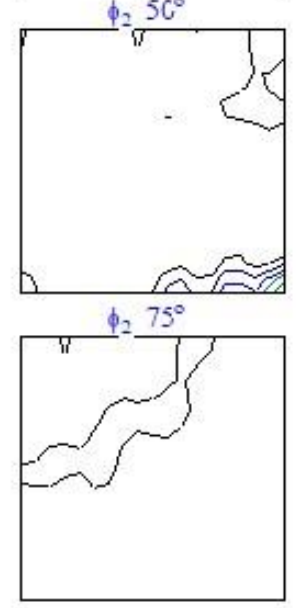

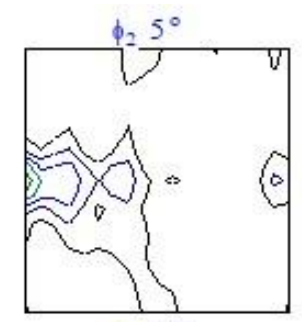

$\phi_{2} 3 \mathrm{c}^{\circ}$

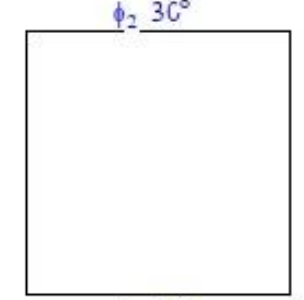

$\phi_{2} \frac{55^{\circ}}{1}$
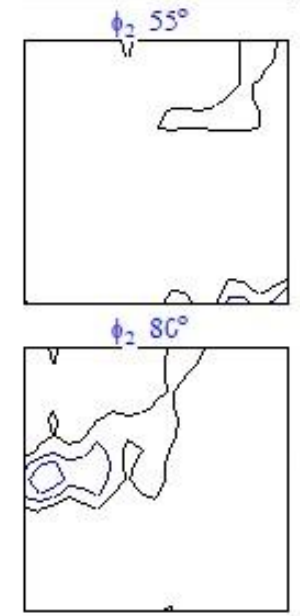
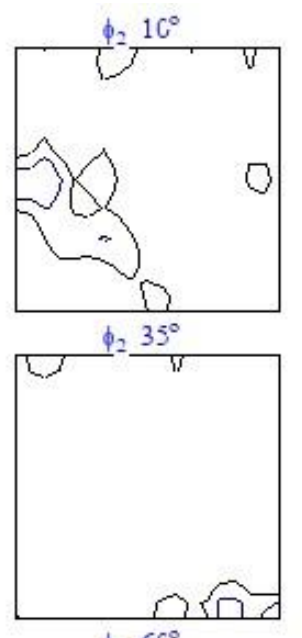

$\phi_{2} 60^{\circ}$

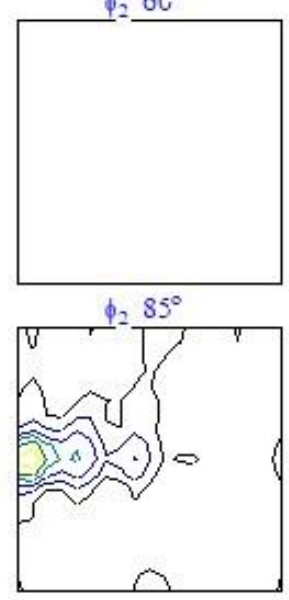

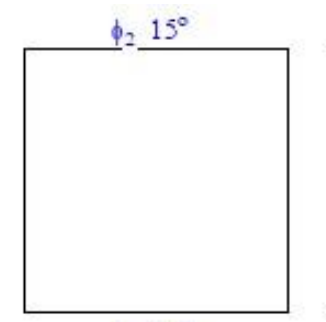

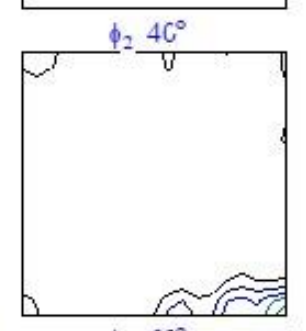

$\phi_{2} 65^{\circ}$

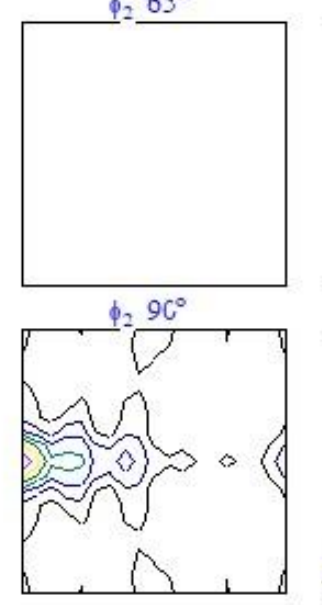

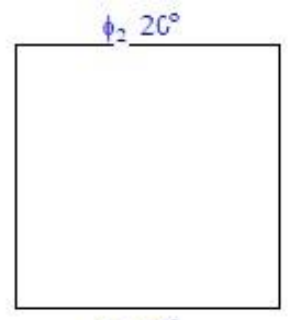

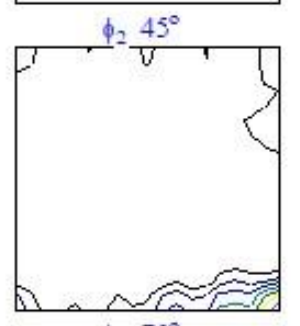

$\phi_{2} 7 \mathrm{C}^{\circ}$

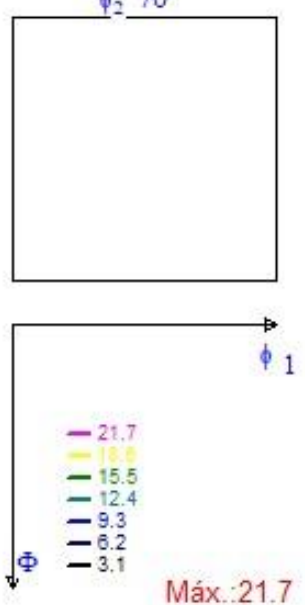

Figura 106 - FDO relativa à superfície de laminação da amostra A 60

Já a amostra B 60 apresenta somente a componente Goss ( $f(g)=22,4)$, não sendo possível identificar quaisquer outras componentes secundárias, conforme FDO apresentada na Figura 107. Observa-se, portanto, que graus mais elevados de deformação tendem (conforme seria esperado) a eliminar a presença das componentes de textura do material recozido. Nota-se também que quando a deformação é provocada por um maior número de passes, existe a tendência da formação de textura do tipo Goss, enquanto um menor número de passes faz com que as orientações fiquem espalhadas entre a textura do tipo Goss e a do tipo Latão. As observações realizadas até então, permitem inferir que o número de passes possui influência na textura associada ao material deformado. 


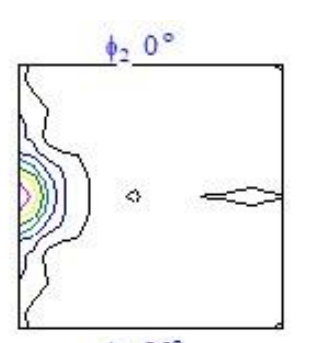

$\phi_{2} 25^{\circ}$
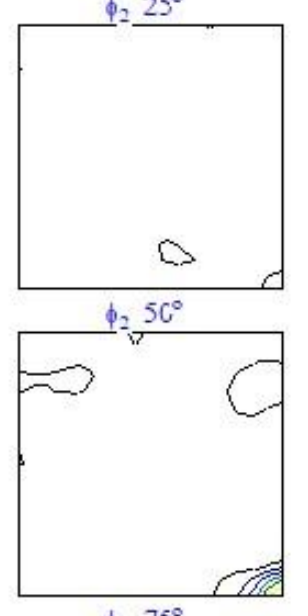

$\phi_{2} 75^{\circ}$

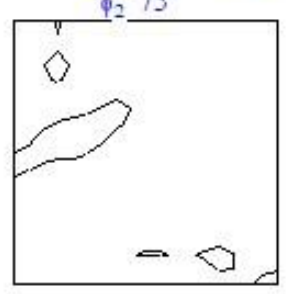

$\phi_{2} 5^{\circ}$

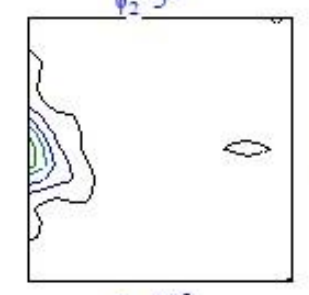

$\phi_{2} 30^{\circ}$
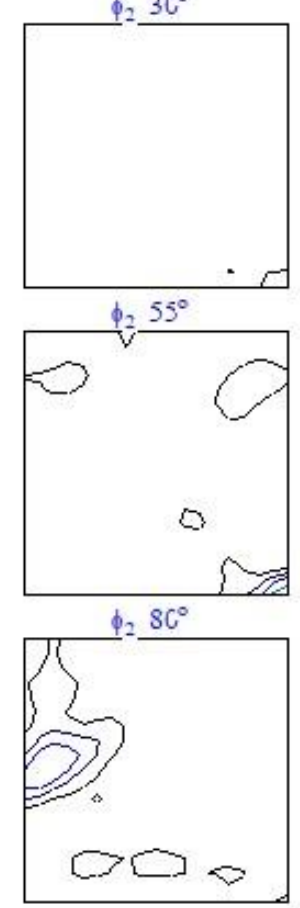

$\phi_{2} 10^{\circ}$

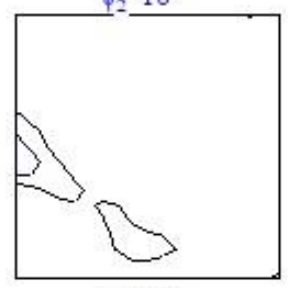

$\phi_{2} 35^{\circ}$

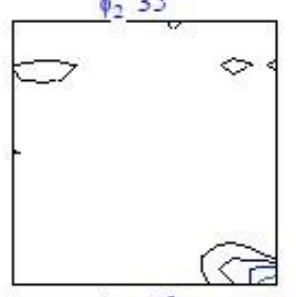

$\phi_{2} 6 \mathrm{C}^{\circ}$

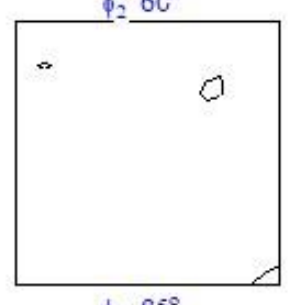

$\phi_{2} 85^{\circ}$

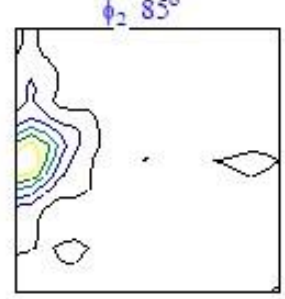

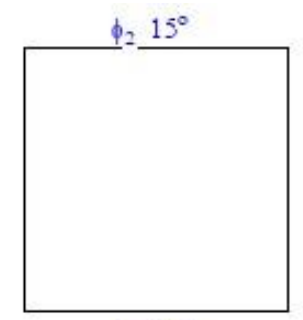

$\phi_{2}$
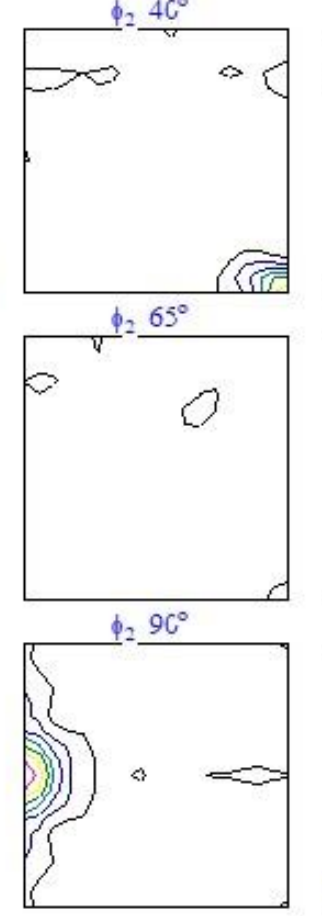

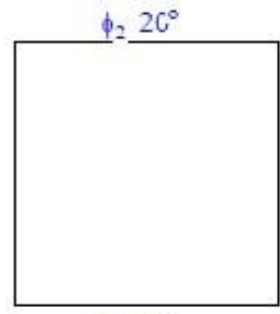

$\phi_{2} 45^{\circ}$

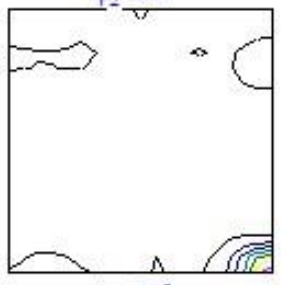

$\phi_{2} 7 \mathrm{C}^{\circ}$
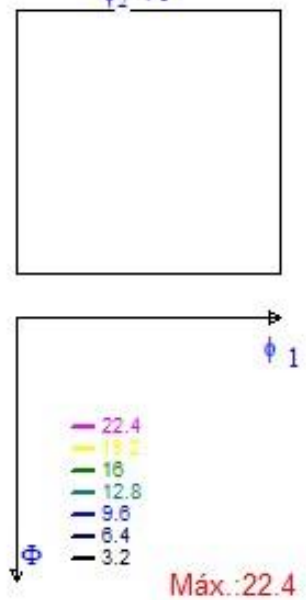

Figura 107 - FDO relativa à superfície de laminação da amostra B 60

O uso de gráficos de fibra permite observar a distribuição das componentes de textura ao longo de direções cristalográficas específicas. A Figura 108 mostra a intensidade de alguns componentes de textura ao longo da direção < 100> para as amostras laminadas A e B. Para as amostras A30 e B30 é possível notar uma diferença substancial entre a textura cristalográfica associada a elas: a amostra B30 apresenta uma forte componente Goss $\{110\}<001>$, enquanto a amostra A30 apresenta uma textura Cubo $\{001\}<110>$, possivelmente remanescente do material extrudado. Assim, a utilização de um maior número de passes para se atingir certo grau de deformação baixa aparenta ser mais eficiente na remoção da textura cristalográfica associada ao processamento anterior. Isso porque, possivelmente, a laminação conduzida por intermédio de mais passes propicia um tempo maior para a acomodação dos átomos em suas novas posições. Para as amostras A 60 e B60 não foram notadas diferenças significativas em relação à direção $<100>$. O elevado grau 
de deformação converte a textura, em ambas as amostras, para a componente Goss $\{110\}<001>$.
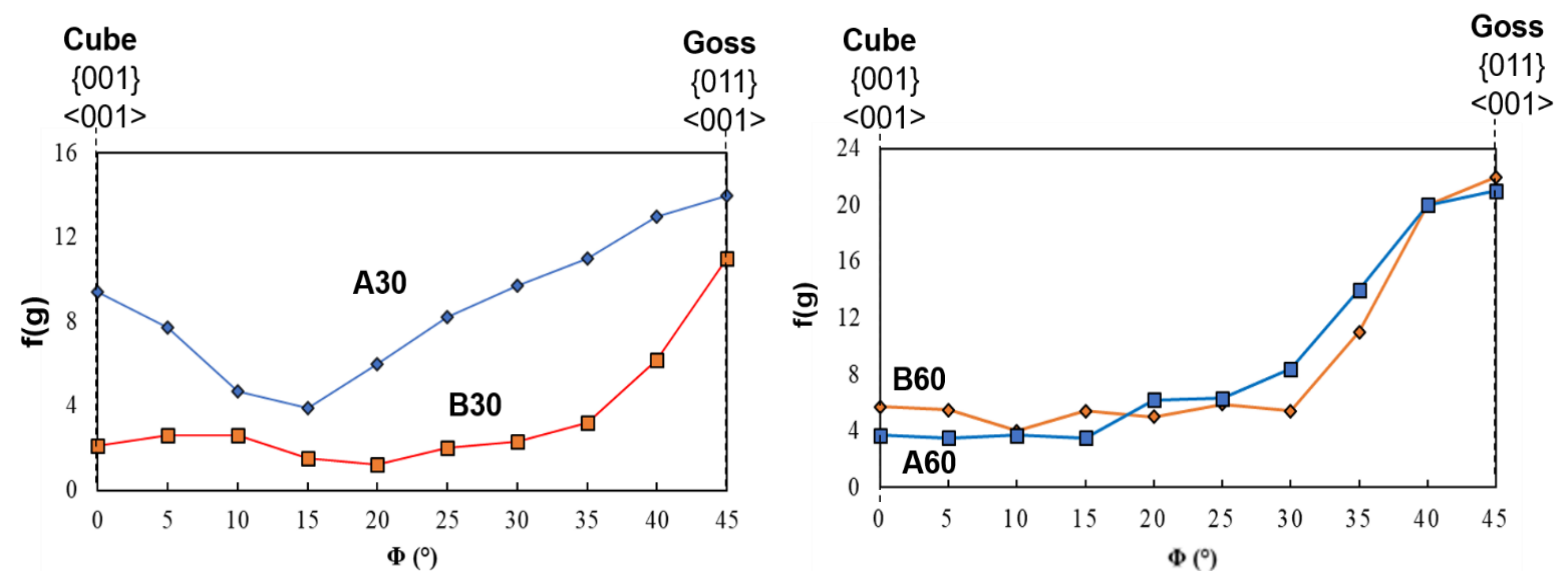

Figura 108 - Gráfico de fibra ao longo da família de direções $<100>\left(\varphi 1=0, \varphi 2=0\right.$ e $\left.0<\phi<45^{\circ}\right)$ relativo às amostras solubilizadas e laminadas a frio

A Figura 109 exibe a fibra $\alpha$ associada às amostras laminadas A e B. Em relação as amostras A30 e B30, nota-se que as amostras laminadas com maior número de passes (B30) tendem a apresentar uma forte componente Goss $\{110\}<001>$, enquanto as amostras laminadas com menor número de passes (A30) tendem a apresentar um misto de componentes Goss $\{110\}<001>$ e Latão $\{011\}<211>$. Novamente, para maiores graus de deformação, as componentes de textura tendem a se assimilar.
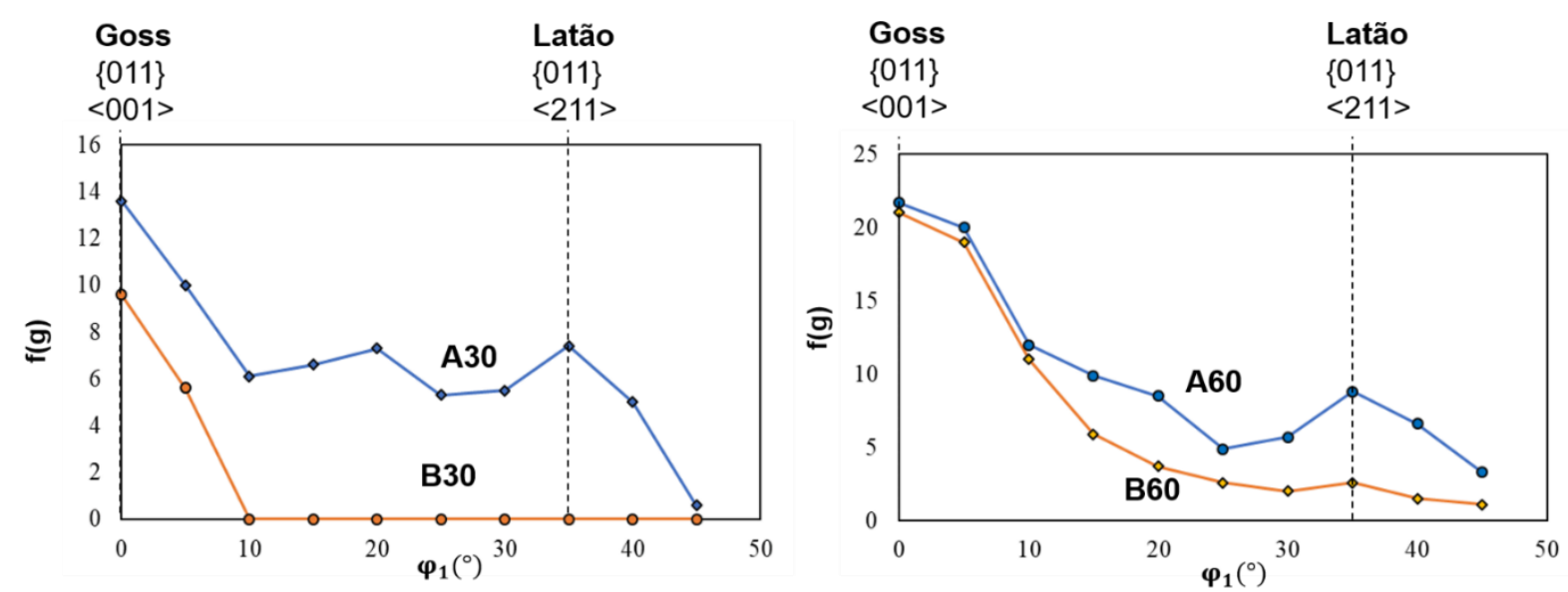

Figura 109 - Gráfico de fibra $\alpha\left(0<\varphi 1<35^{\circ}, \phi=45^{\circ}\right.$ e $\left.\varphi 2=0\right)$ relativo às amostras solubilizadas e laminadas a frio

Cabe, no entanto, observar, que os resultados das medidas de textura associadas às tiras laminadas apresentadas até o momento podem ter uma significativa parcela de contribuição do cisalhamento e atrito superficiais associados ao processos de laminação à frio [65]. 
As tentativas de estudar a microtextura das amostras deformadas por meio da técnica de EBSD foram frustradas, uma vez que uma microestrutura encruada dificulta a utilização dessa técnica, já que a deformação acumulada constitui um obstáculo à ferramenta computacional que faz o ajuste entre os dados coletados pelo detetor de elétrons e os padrões dos diversos materiais metálicos [129] .

\subsection{Caracterização microestrutural, medição de dureza Vickers e obtenção da macro e microtextura cristalográfica das amostras recozidas}

As Figuras 110 e 111 e exibem micrografias ópticas obtidas com o auxílio de luz polarizada relativas às amostras $\mathrm{A} 30$ e B30 após recozimento a $490^{\circ} \mathrm{C}$ por uma hora, respectivamente. Comparadas às amostras encruadas (vide Figura 97), nota-se que as micrografias das amostras recozidas apresentam grãos de cores mais bem definidas, indicando uma estrutura parcialmente recuperada, uma vez que não foram identificados novos grãos recristalizados. Uma vez que não foi constatada a ocorrência de recristalização, o estudo passou a ser focado nas amostras submetidas a maiores graus de deformação.

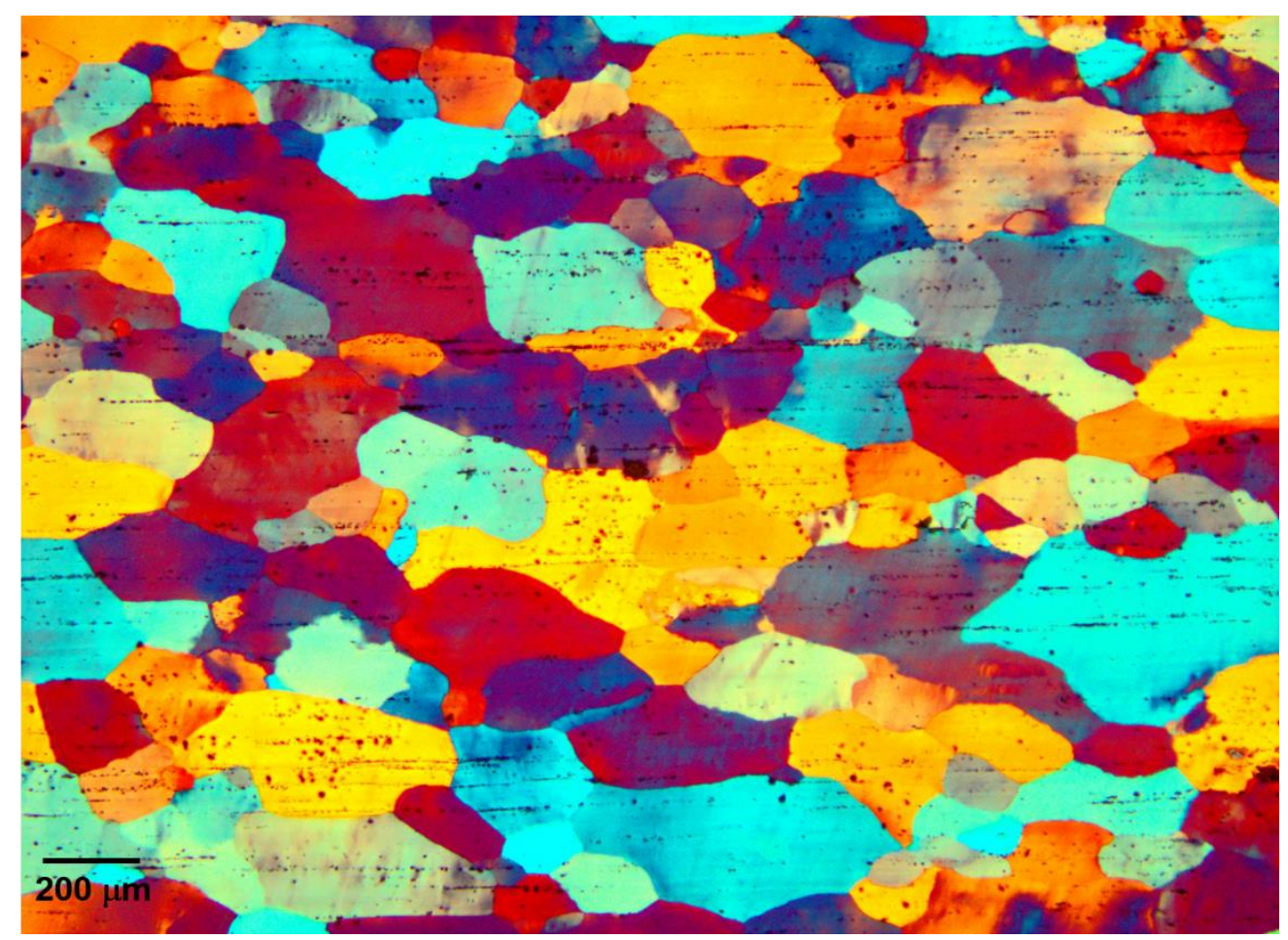

Figura 110 - Micrografia óptica obtida com auxílio de luz polarizada para a amostra deformada por laminação (A30) seguida de recozimento a $490^{\circ} \mathrm{C}$ por 1 hora 


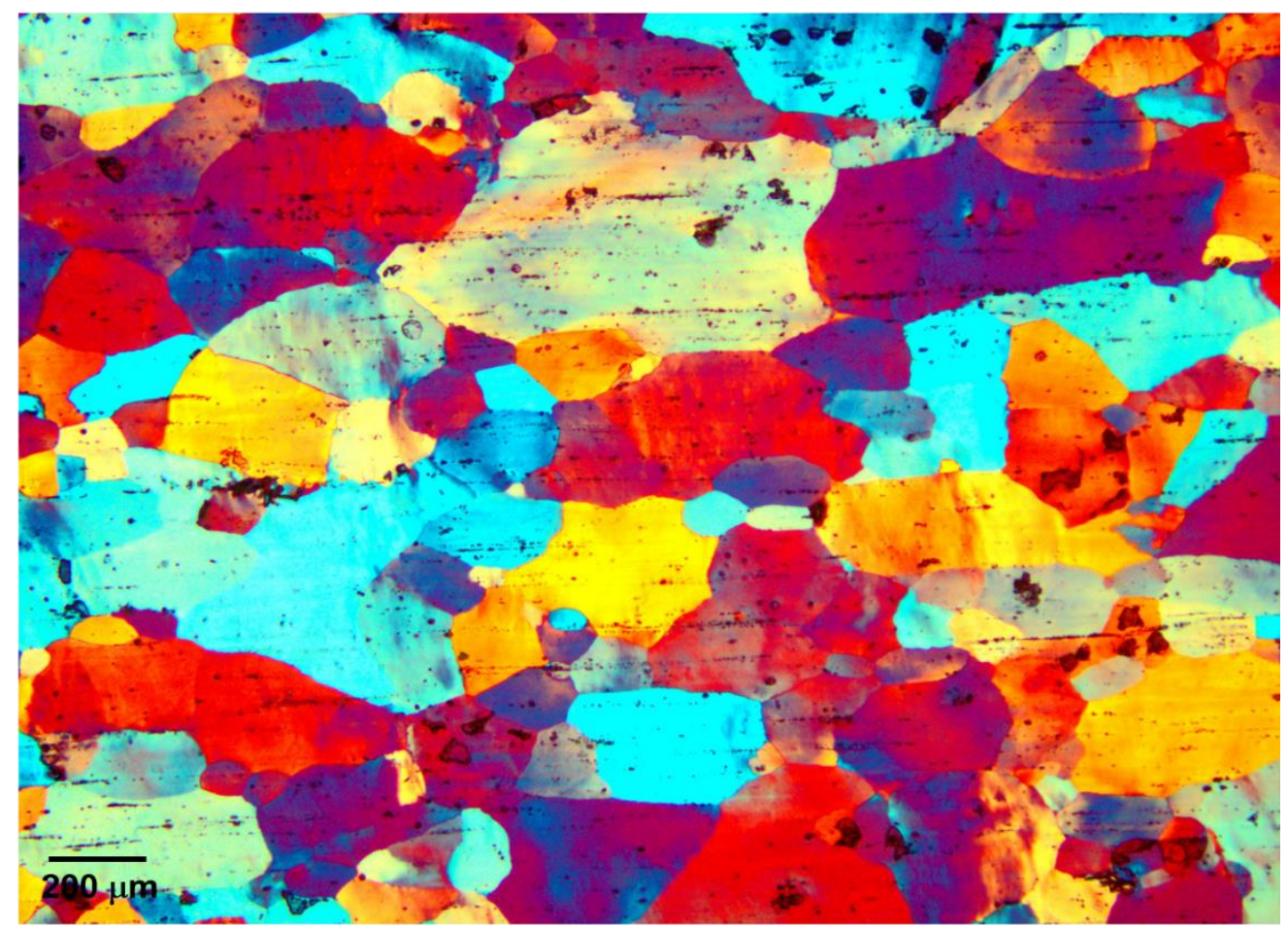

Figura 111 - Micrografia óptica obtida com auxílio de luz polarizada para a amostra deformada por laminação (B30) seguida de recozimento a $490^{\circ} \mathrm{C}$ por 1 hora

As Figuras 112 e 113 exibem micrografias ópticas obtidas com o auxílio de luz polarizada relativas às amostras $\mathrm{A} 60$ e $\mathrm{B} 60$ após recozimento a $490^{\circ} \mathrm{C}$ por uma hora, respectivamente. Como as amostras " $A$ " foram submetidas a maiores taxas de deformação, essas acumulam maior quantidade de energia associada à defeitos cristalinos e tendem, dessa maneira, a sofrer recristalização com mais facilidade [73]. Isso pode ser observado nas regiões sinalizadas por setas na Figura 112, que indicam a formação de pequenos grãos recristalizados. Ao mesmo tempo, observa-se também uma matriz ainda encruada, indicando que a recristalização não foi finalizada. Por outro lado, nas amostras "B", submetidas a menores taxas de deformação, não foram observados novos grãos recristalizados. Ao invés, disso, foi observado um intenso crescimento de grão e recuperação. Isso pode também ser explicado com base na energia associada aos defeitos cristalinos: como as amostras "B" foram deformadas mais lentamente, o material retém menor parcela da energia empregada na deformação. Esse menor nível de energia, associado a uma deformação mais lenta, tende a dificultar recristalização enquanto promove o crescimento de grão e a recuperação [71]. 


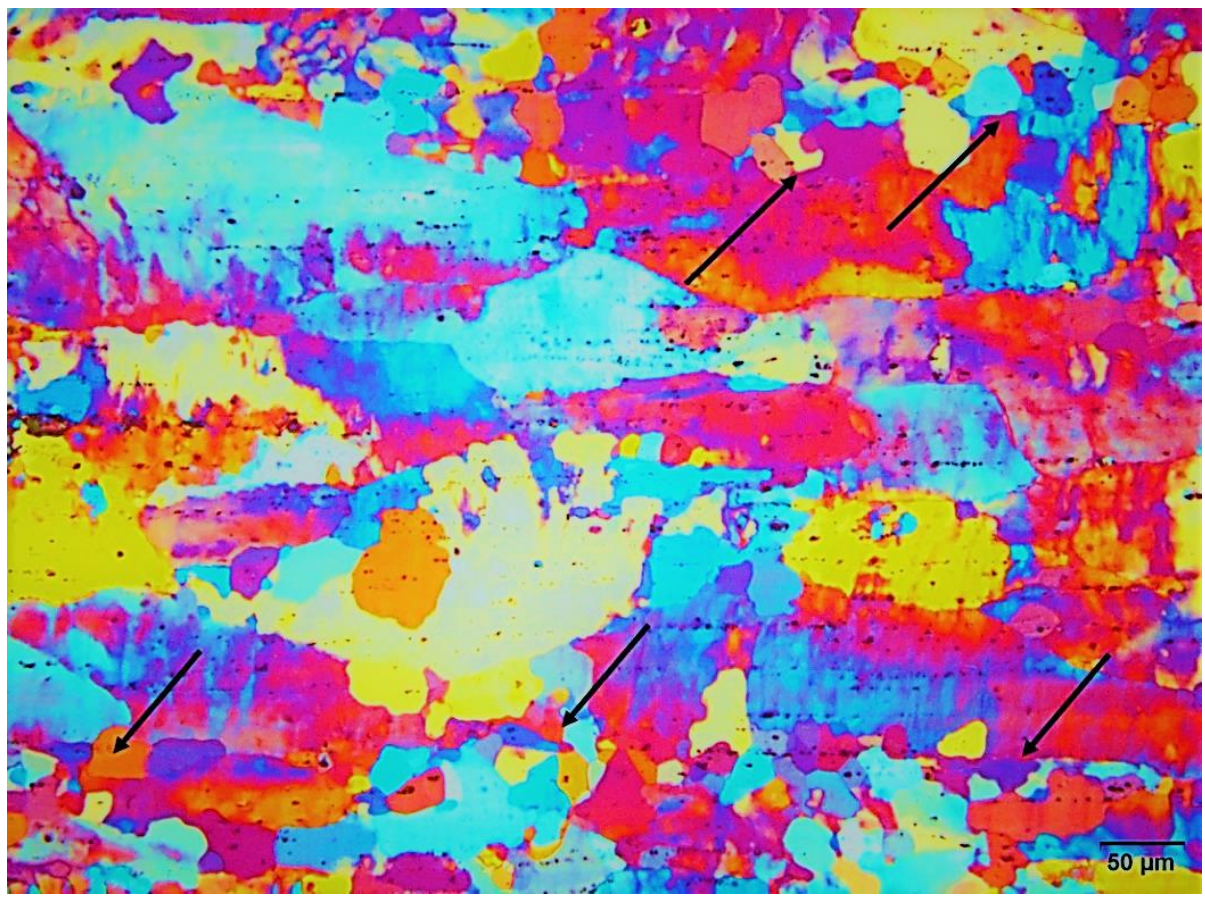

Figura 112 - Micrografia óptica obtidas com auxílio de luz polarizada para a amostra deformadas por laminação (A60) seguida de recozimento a $490^{\circ} \mathrm{C}$ por 1 hora. As flechas indicam pequenos grãos recristalizados em meio ao material encruado

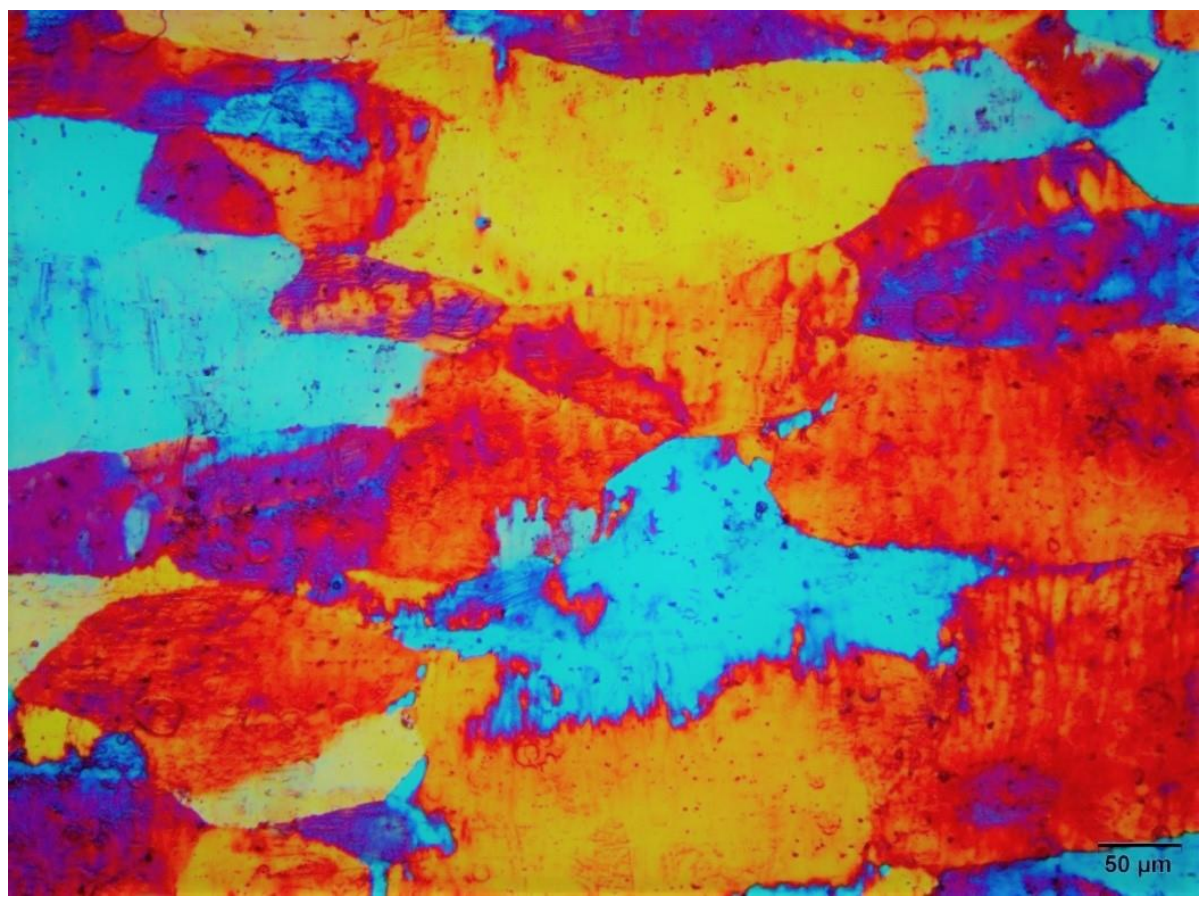

Figura 113 - Micrografia óptica obtida com auxílio de luz polarizada para a amostra deformada por laminação (B60) seguida de recozimento a $490^{\circ} \mathrm{C}$ por 1 hora

As Figuras 114 e 115 mostram micrografias ópticas obtidas com o auxílio de luz polarizada relativas às amostras $\mathrm{A} 60$ e $\mathrm{B} 60$ após recozimento a $490^{\circ} \mathrm{C}$ por 14 horas, respectivamente. Novamente, a amostra A, submetida a maiores taxas de deformação, apresentou tendência à formação de novos grãos recristalizados, 
enquanto a amostra $B$ apresentou apenas recuperação e intenso crescimento de grão. O aumento do tempo de recozimento aumenta, no caso das amostras $A$, aumenta a fração de novos grãos recristalizados (de aproximadamente 10\% para aproximadamente $17 \%$ ) mas não é o suficiente para promover a recristalização completa do material, conforme pode ser observado na Figura 114. Como o alumínio e suas ligas apresentam elevada energia de defeito de empilhamento (EDE), elas apresentam tendência a sofrer recuperação, o que diminui a energia interna associada aos defeitos e, por consequência, diminui o potencial de ocorrência de recristalização [73]. Dessa forma, explica-se o fato de que ambas as amostras apresentam baixa (praticamente nula, no caso da B60) fração de novos grãos recristalizados e a presença de grãos grosseiros oriundo do crescimento desses em função do tempo e da temperatura de recozimento.

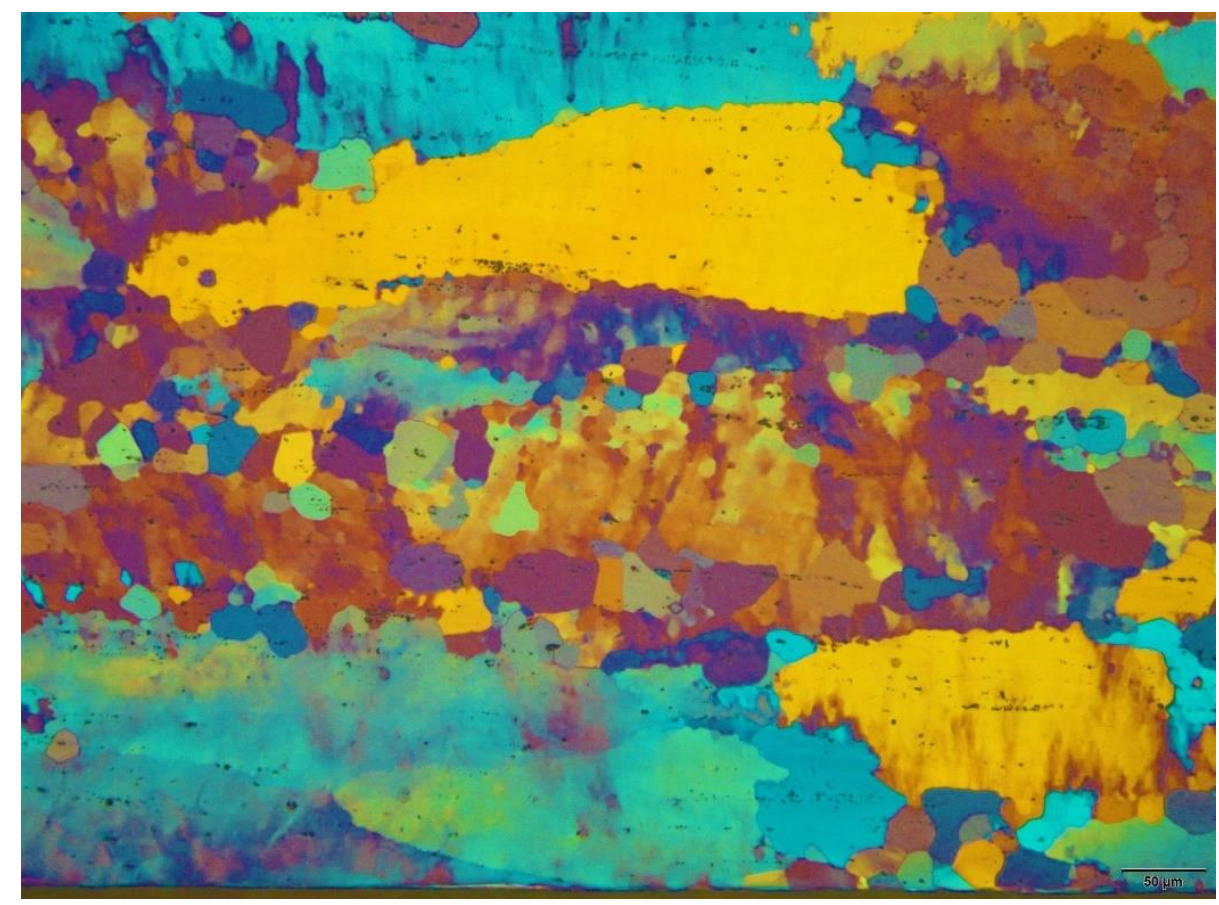

Figura 114 - Micrografia óptica obtida com auxílio de luz polarizada para a amostra deformada por laminação (A60) seguida de recozimento a $490^{\circ} \mathrm{C}$ por 14 horas 


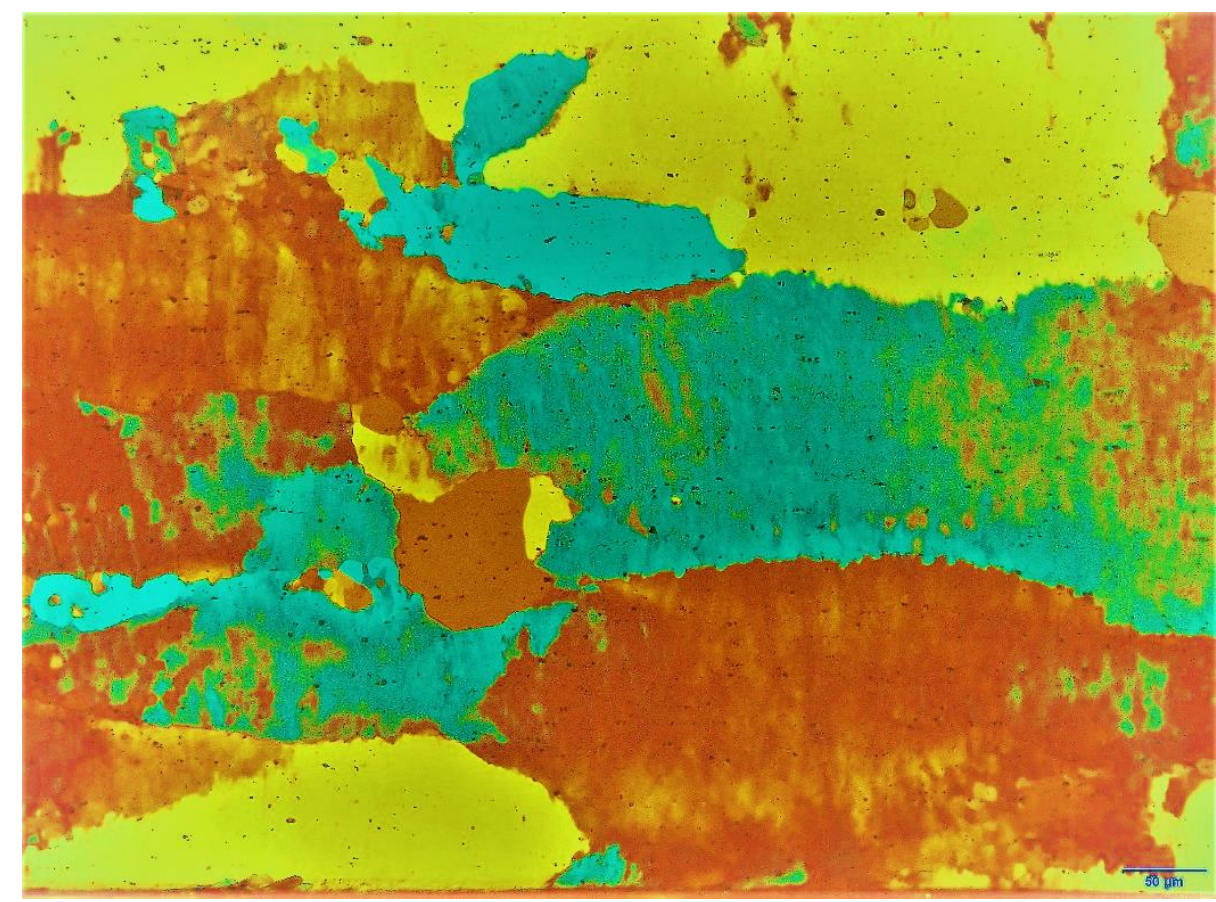

Figura 115 - Micrografia óptica obtida com auxílio de luz polarizada para a amostras deformada por laminação (B60) seguida de recozimento a $490^{\circ} \mathrm{C}$ por 14 horas

O comportamento mecânico do material recozido com o passar do tempo em temperatura ambiente (aproximadamente $25^{\circ} \mathrm{C}$ ) é expresso pelo gráfico de dureza Vickers em relação ao tempo exibido na Figura 116, onde as linhas tracejadas indicam a curva que melhor se ajusta aos dados experimentais. Observa-se que as amostras recozidas por mais tempo apresentam menores níveis de dureza. Isso porque o recozimento promove, seja por recristalização ou por recuperação, a diminuição da concentração de defeitos cristalinos, implicando a queda da dureza observada. Por outro lado, para cada uma das situações, nota-se o aumento da dureza com o passar do tempo, mais uma vez em função do envelhecimento natural. 

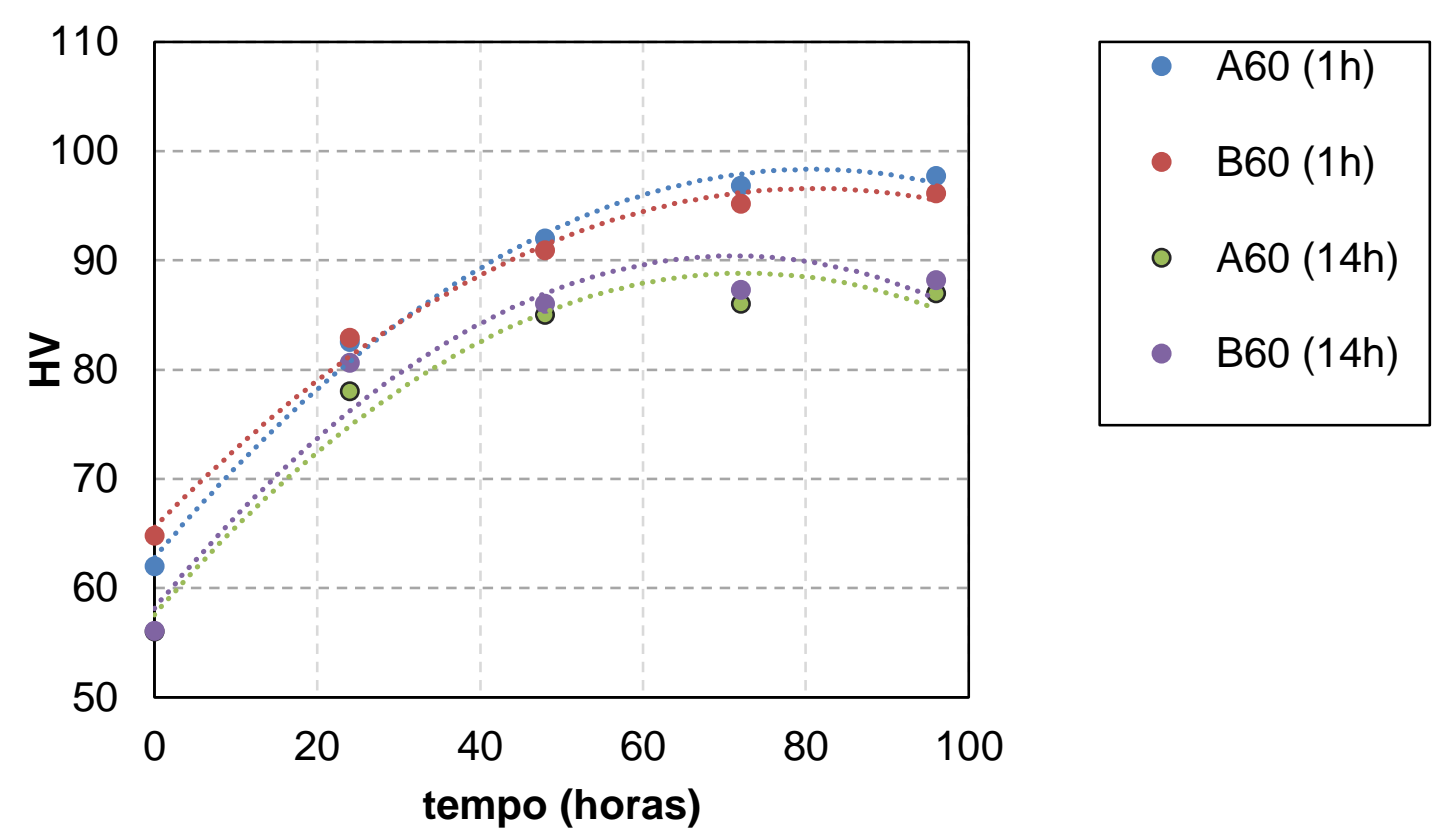

Figura 116 - Variação da dureza com o tempo das amostras A60 e B60 recozidas e deixadas em temperatura ambiente (aproximadamente a $25^{\circ} \mathrm{C}$ )

Os dados experimentais podem ser ajustados a uma equação polinomial de segundo grau com bom nível de concordância. A Tabela 15 exibe os parâmetros de ajuste considerando um modelo matemático do tipo "ax ${ }^{2}+b x+c$ ", onde "a","b" e "c" correspondem aos coeficientes da equação e "R" ao coeficiente de correlação. Novamente, o ajuste ao modelo quadrático funciona bem para intervalos de tempo compreendidos entre o tempo inicial e o tempo em que a dureza máxima é atingida.

Tabela 15 - Parâmetros de ajuste entre modelos polinomiais do segundo grau e os dados empíricos relativos ao envelhecimento natural das amostras deformadas

\begin{tabular}{ccccc}
\hline Amostra & $\mathbf{a}$ & $\mathbf{b}$ & $\mathbf{c}$ & $\mathbf{R}^{2}$ \\
\hline A60 (1h) & $-0,0055$ & 0,8851 & 62,9690 & 0,9906 \\
B60 (1h) & $-0,0047$ & 0,7657 & 65,5570 & 0,9925 \\
A60 (14h) & $-0,0057$ & 0,8477 & 57,5570 & 0,9622 \\
B60 (14h) & $-0,0064$ & 0,9061 & 58,1310 & 0,9494 \\
\hline
\end{tabular}

As Figuras 117 e 118 exibem as FDO's obtidas por difratometria de raios $\mathrm{X}$ para as amostras $\mathrm{A} 60$ e $\mathrm{B} 60$ recozidas a $490^{\circ} \mathrm{C}$ por 14 horas, respectivamente. Com relação a amostra $A 60$ recozida, nota-se a redução da intensidade de componentes Cubo e Goss (presentes na amostra encruada) e o aumento da intensidade da componente $(113)<332>$ cujos ângulos de Euler são $\varphi 1=90^{\circ}, \varphi 2=45^{\circ}$ e $\Phi=25^{\circ}$. Tal 
componente é associada à recristalização secundária em ligas de alumínio, conforme apontado por Gow [123], e indicam a predominância do crescimento de grão em relação à recristalização. Por outro lado, observa-se que a amostra B60 apresentou, após recozimento, componente remanescente Goss, junto com outras texturas ao longo da fibra $\langle 110\rangle$, além de componentes cujos planos são paralelos aos planos da família (113).

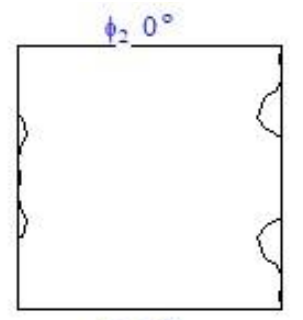

$\phi_{2} 25^{\circ}$

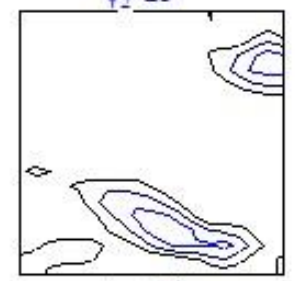

$\phi_{2} 5 \mathrm{C}^{\circ}$

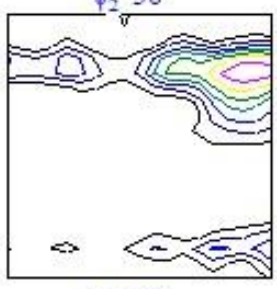

$\phi_{2} 75^{\circ}$

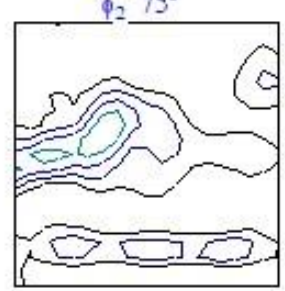

$\phi_{2} 5^{\circ}$

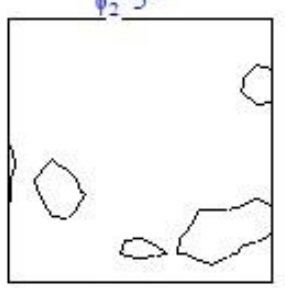

$\phi_{2} 3 c^{\circ}$

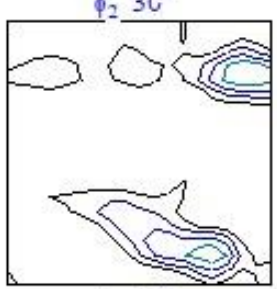

$\phi_{2} 55^{\circ}$

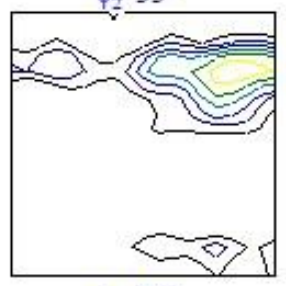

$\phi_{2} S \mathrm{C}^{\circ}$

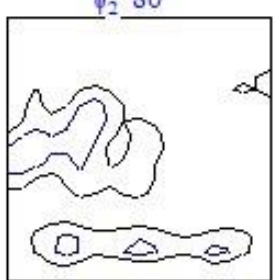

$\phi_{2} 10^{\circ}$

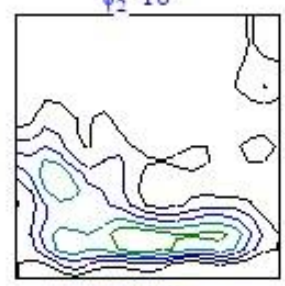

$\phi_{2} 35^{\circ}$

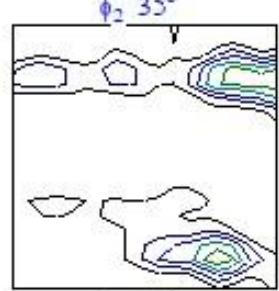

$\phi_{2} 6 \mathrm{C}^{\circ}$

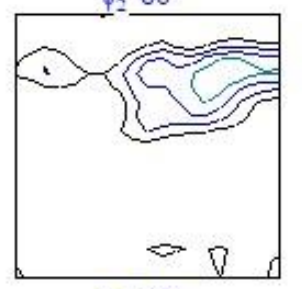

$\phi_{2} 85^{\circ}$

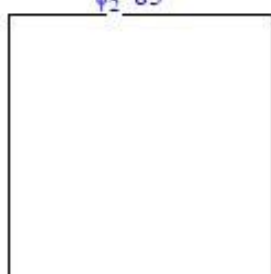

$\phi_{2} 15^{\circ}$

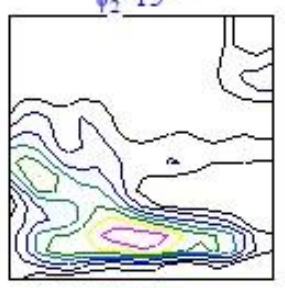

$\phi_{2} 4 \mathrm{C}^{\circ}$

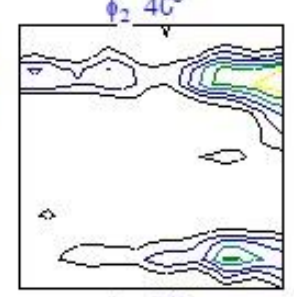

$\phi_{2} 65^{\circ}$

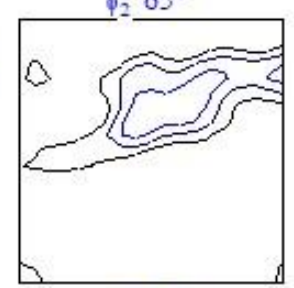

$\phi_{2} 90^{\circ}$

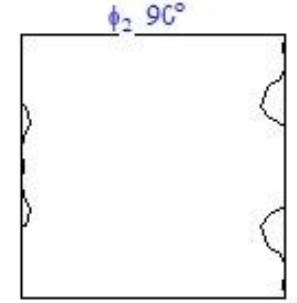

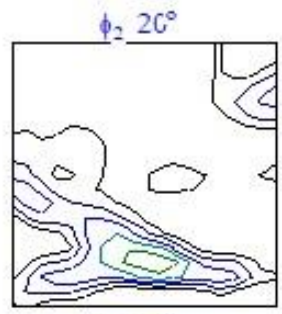

$\phi_{2} 45^{\circ}$

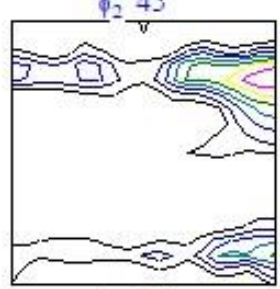

$\phi_{2} 7 \mathrm{C}^{\circ}$
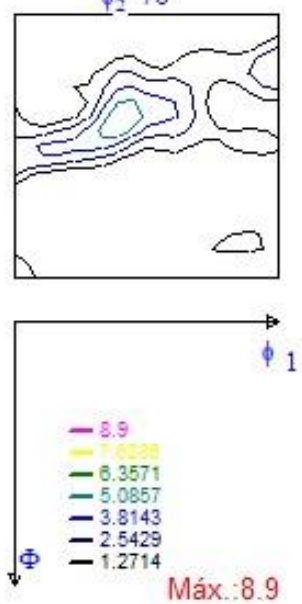

Figura 117 - FDO relativa à superfície de laminação da amostra A 60 após tratamento térmico a $490^{\circ} \mathrm{C}$ por 14 horas 


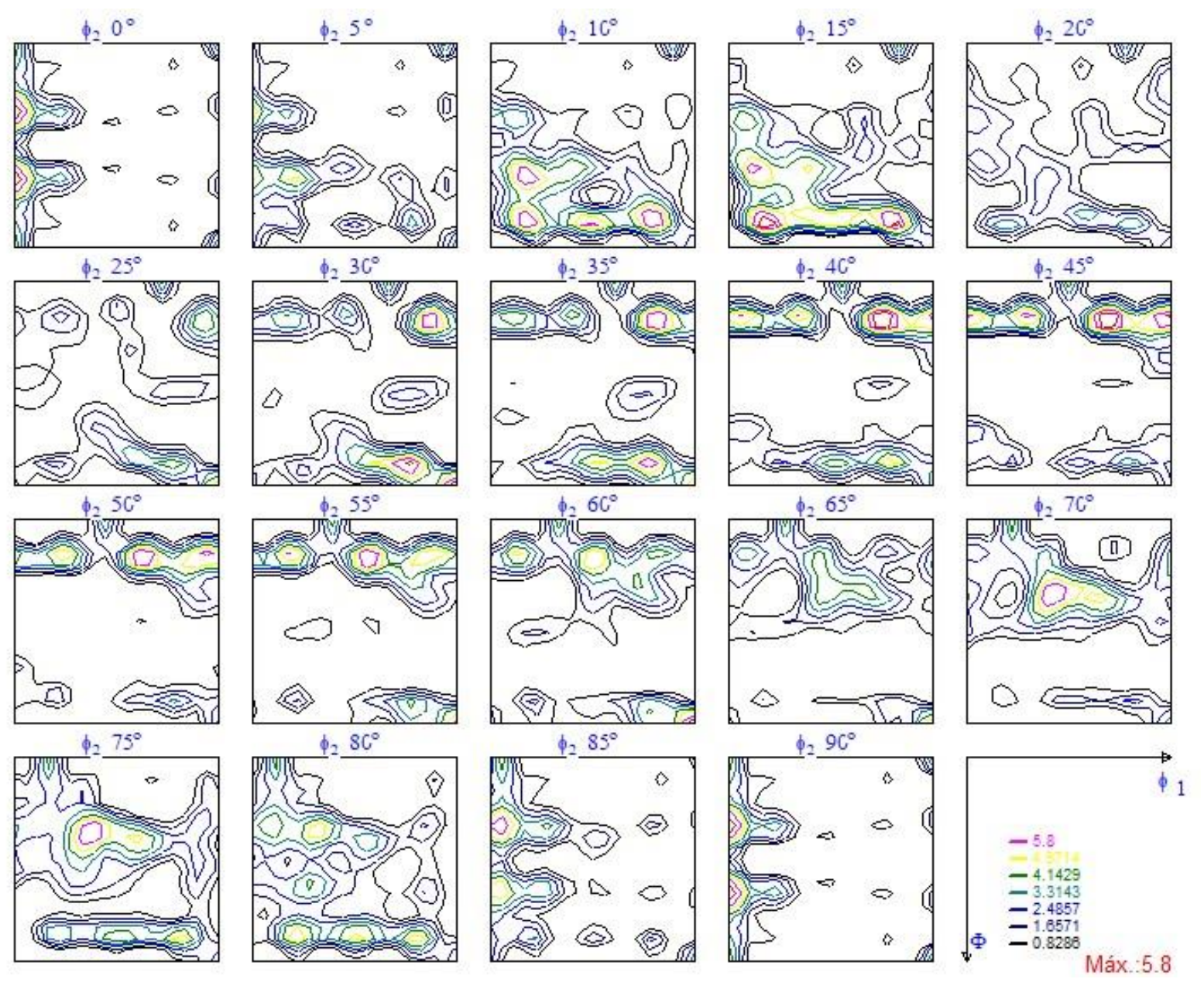

Figura 118 - FDO relativa à superfície de laminação da amostra B 60 após tratamento térmico a $490^{\circ} \mathrm{C}$ por 14 horas

A Figura 119 mostra a intensidade de alguns componentes de textura ao longo da direção $<001>$ para as amostras $\mathrm{A} 60$ e $\mathrm{B} 60$ recozidas a $490^{\circ} \mathrm{C}$ por 14 horas. Além das texturas Cubo e Goss remanescentes, nota-se, para a amostra B60, a presença de uma componente cujos ângulos de Euler são $\varphi 1=0, \varphi 2=0$ e $\phi=30^{\circ}$. Já a amostra A 60, apresentou componentes de baixa intensidade ao longo dessa fibra, indicando que a adoção de um número diferente de passes durante a laminação a frio (ou seja, a adoção de diferentes taxas de deformação para se atingir o mesmo grau de deformação) promove intensa diferença entre a orientação dos grãos de ambos os materiais após recozimento. Já a Figura 120 mostra a intensidade de alguns componentes de textura (ao longo da faixa de ângulos $0<\varphi 1<90^{\circ}, \varphi 2=45^{\circ} \mathrm{e} \phi=$ $25^{\circ}$ ) para as amostras $A 60$ e $B 60$ recozidas a $490^{\circ} \mathrm{C}$ por 14 horas. Sabe-se que texturas associadas ao crescimento anormal de grão são comumente encontradas ao longo dessa fibra [123], indicando que o mecanismo da recristalização secundária é 
atuante em ambas as amostras, ainda que seja predominante na A60, a amostra deformada com menos passes.

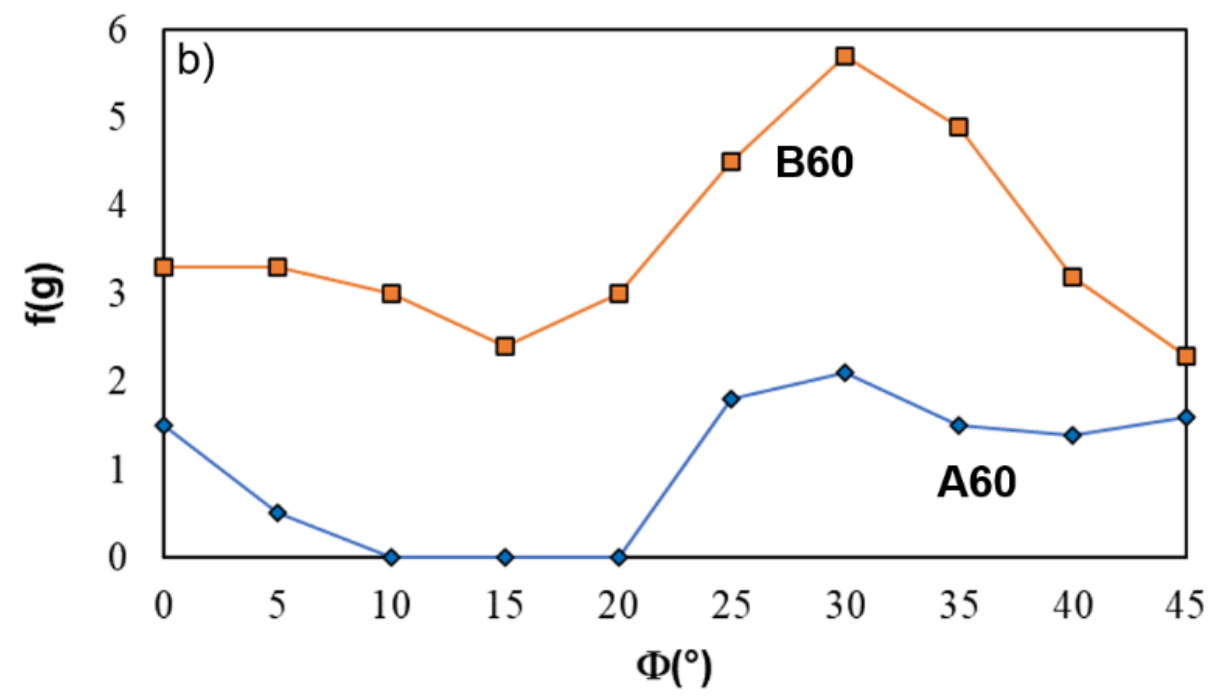

Figura 119 - Gráfico de fibra ao longo da família de direções $<100>\left(\varphi_{1}=0, \varphi_{2}=0\right.$ e $\left.0<\phi<45^{\circ}\right)$ relativo às amostras $\mathrm{A} 60$ e $\mathrm{B} 60$ recozidas por 14 horas a $490^{\circ} \mathrm{C}$

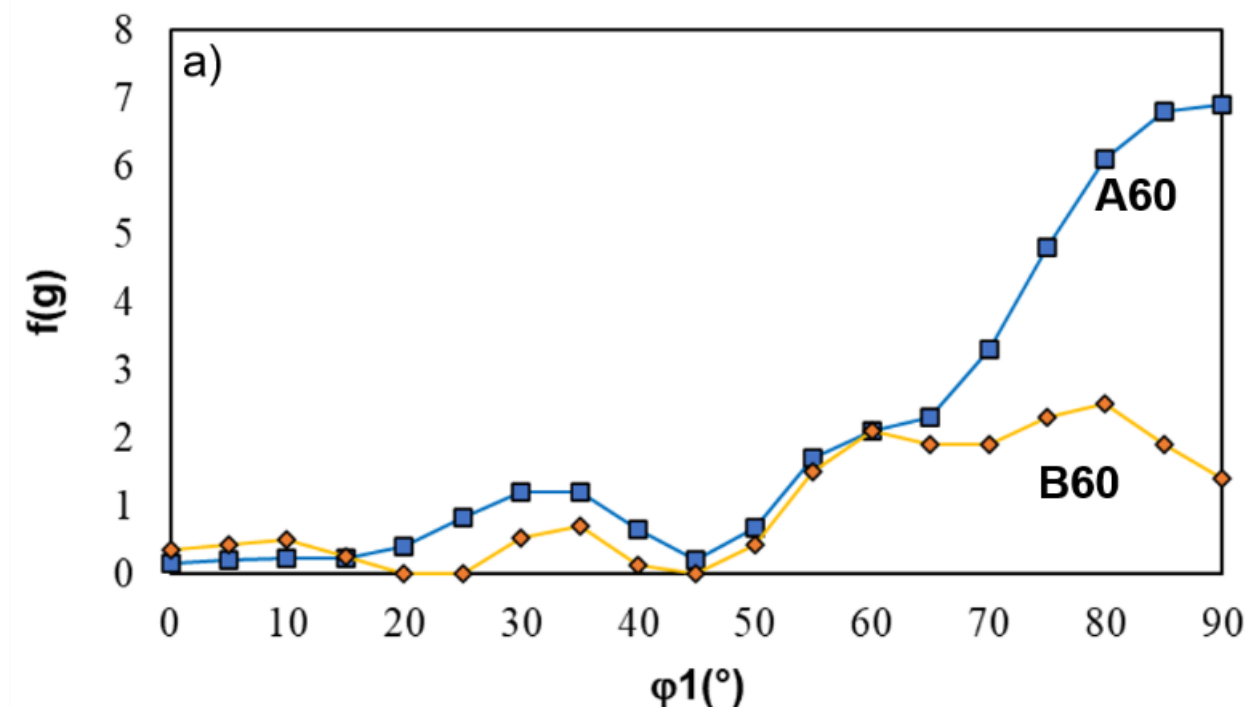

Figura 120 - Gráfico de fibra (ao longo da faixa de ângulos $0<\varphi 1<90^{\circ}, \varphi 2=45^{\circ} \mathrm{e} \phi=25^{\circ}$ ) relativo às amostras A60 e B60 recozidas por 14 horas a $490^{\circ} \mathrm{C}$

Por fim, a difratometria, como técnica para a obtenção da macrotextura, não permite a determinação da orientação individual de cada grão. Portanto, para amostras com baixa fração de novos grãos recristalizados, como é o caso da amostra A60 recozida, a técnica não se faz adequada para estudar a textura de recristalização do material para as condições estudadas. Dessa forma, foi realizada a tentativa de determinar a orientação desses grãos via EBSD. O mapa de orientações para a amostra A60 recozida por 14 horas a $490^{\circ} \mathrm{C}$ é exibido na Figura 121. O mapa revela 
uma estrutura ainda encruada, o que dificulta a utilização dessa técnica haja vista que a deformação acumulada é um obstáculo para a ferramenta computacional que faz 0 ajuste entre os dados coletados pelo detetor de elétrons e os padrões dos diversos materiais metálicos. Ainda assim, é possível observar a formação de pequenos grãos recristalizados, de orientações aproximadamente paralelas aos planos (001) e (111). Entretanto, como o EBSD abrange uma área pouco representativa da amostra, há dificuldade em estabelecer com precisão se tais orientações representam, de maneira estatisticamente confiável, a textura cristalográfica associada aos grãos recristalizados.
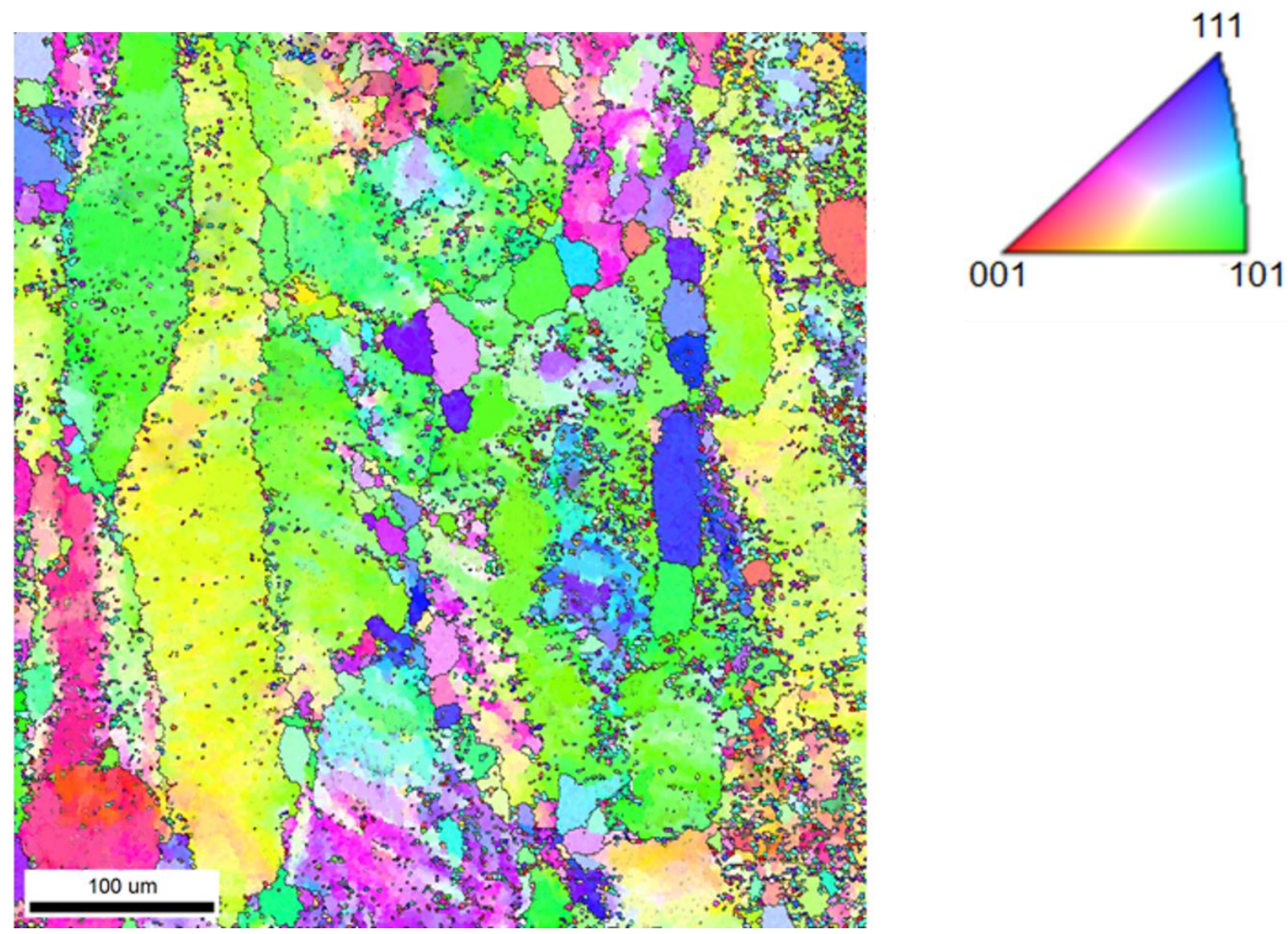

Figura 121 - Mapeamento de orientações (EBSD) da amostra $\mathrm{A} 60$ recozida a $490^{\circ} \mathrm{C}$ 


\section{CONCLUSÕES}

1 - O lingote da liga de alumínio 7108 na condição bruta de solidificação apresentou microestrutura dendrítica bem definida, com evidências de segregação interdendrítica e formação de compostos intermetálicos alongados nesta região. Após o tratamento térmico de homogeneização, realizado em escala industrial na CBA, na temperatura de $486{ }^{\circ} \mathrm{C}$ por 10 horas, houve significativa dissolução dos compostos intermetálicos interdendríticos e redução da microssegregação.

2 - A AA 7108 no estado inicial (barra retangular extrudada) apresentou uma estrutura de grãos totalmente recristalizados e aproximadamente equiaxiais, sendo que nas bordas da secção transversal foi observado o fenômeno de crescimento dos grãos periféricos (PCGZ). Apesar disso, não foi detectada diferença entre a dureza medida nas bordas ou no centro da secção transversal. Com relação à textura cristalográfica, observou-se que a liga apresenta textura do tipo Cubo na superfície de extrusão e componente do tipo Goss na secção relativa à metade da espessura. A principal componente de textura da PCGZ, por sua vez, foi identificada como sendo $\{311\}<110>$. A determinação da macrotextura permite inferir que o mecanismo que dá origem a essa zona de grãos grosseiros é o crescimento anormal de grão, também conhecido como recristalização secundária.

3 - A solubilização da AA 7108 a $490^{\circ} \mathrm{C}$ por 5 horas promoveu a queda de dureza, conforme esperado, em função da dissolução de zonas GP e de intermetálicos, formados durante o processamento termomecânico, causadores do aumento de resistência mecânica. Após solubilização, constatou-se que as amostras endureciam com o passar do tempo à temperatura ambiente de forma a atingir um patamar de cerca de $85 \mathrm{HV}$ em um período de 5 dias. Por outro lado, observou-se que as amostras solubilizadas possuíam condutividade elétrica maior do que o material no estado inicial. Notou-se, também de maneira inesperada, que a condutividade elétrica das amostras tendia a diminuir com o passar do tempo quando essas eram deixadas a temperatura ambiente. As observações experimentais indicam que, para a liga estudada, a formação de Zonas GP aumenta a resistência elétrica mais do que a presença de átomos de soluto, fenômeno conhecido como comportamento anômalo da condutividade elétrica durante o envelhecimento. 
4 - Após solubilização, amostras da AA 7108 laminadas, com diferente número de passes, apresentaram diferenças significativas em relação à dureza e a textura cristalográfica. As amostras laminadas com maior número de passes apresentaram componentes principais de textura do tipo Goss, enquanto amostras laminadas com menor número de passes apresentaram, além da componente Goss, a componente Latão. Em relação à dureza, amostras laminadas com mais passes apresentaram dureza média menor, em relação às amostras laminadas com menos passes. Ambas as observações podem ser explicadas com base no número de passes adotados para se atingir o mesmo grau de deformação: mais passes permitem que os planos atômicos tenham mais tempo para deslizar uns sobre os outros de modo a acomodar a deformação e acomodar a orientação final dos grãos de maneira mais eficiente. Nota-se, nesse ponto, que o atrito e o cisalhamento superficial presentes no processo de laminação podem ter, de acordo com a literatura, influenciado significativamente as medidas de textura obtidas

5- A Após recozimento a $490^{\circ} \mathrm{C}$, as amostras laminadas com menos passes apresentam microestrutura parcialmente recristalizada e por grãos que sofreram crescimento exagerado. Já as amostras deformadas de maneira mais lenta tendem, após recozimento, a apresentar uma microestrutura parcialmente recuperada e com tamanho médio de grão maior em relação às amostras deformadas mais rapidamente. No tocante à macrotextura, observou-se que as amostras laminadas com menor número de passes, e em seguida recozidas, apresentaram intensa componente (113) $<332>$, frequentemente associada ao crescimento anormal de grão. Por sua vez, as amostras deformadas com maior número de passes tenderam a manter as componentes Cubo e Goss, remanescentes dos processos de deformação anteriores, além de também apresentar texturas associadas à família de planos (113), mas com menor intensidade relativa. 


\section{SUGESTÕES PARA TRABALHOS FUTUROS}

A continuidade das pesquisas com a AA 7108 pode acontecer em algumas frentes diferentes de modo a abordar questões não esclarecidas no presente trabalho.

Primeiramente, maiores graus de deformação podem ser utilizados com o objetivo de promover a completa recristalização do material e possibilitar a avaliação da textura gerada em função da velocidade e do grau de deformação adotados.

O estudo do efeito de diferentes temperaturas de solubilização na cinética de recristalização estática e no tamanho de grão recristalizado poderá contribuir para a otimização do processamento e das propriedades da liga 7108 .

A questão do comportamento anômalo (aumento da condutividade elétrica após solubilização da liga) deve ser mais bem explorada com auxílio da combinação de microscopia eletrônica de transmissão de alta resolução e de técnicas de espalhamento de baixo ângulo (Small Angle X-Ray Scattering - SAXS). A utilização dessas técnicas poderá elucidar a influência da formação de aglomerados ("clusters") de átomos, zonas GP e/ou de precipitados nanométricos no comportamento anômalo observado.

Os estudos de corrosão na liga 7108 são escassos e devem ser ampliados. Por exemplo, o comportamento distinto (durante o ataque químico com reagente de Tucker) associado às amostras bruta de solidificação e homogeneizada sugere que um futuro estudo eletroquímico sistemático sobre o efeito do tratamento térmico de homogeneização será muito oportuno. 


\section{REFERÊNCIAS BIBLIOGRÁFICAS}

1. WANG, X. F. et al. The evolution of microstructure and texture during thermomechanical processing of Al-Mg-Si-Cu alloy. Materials Science Forum, v. 794-796, p. 1141-1146, 2014.

2. PARK, J. K. Influence of Retrogression and Reaging Treatments on the Strength and Stress Corrosion Resistance of Aluminium Alloy 7075-T6. Materials Science and Engineering: A, v. 103, n. 2, p. $223-231,1988$.

3. JURCZAK, W.; PH, D. Dynamic properties of 7000 - series aluminum alloys at large strain rates. Polish Maritime Research, v. 19, n. 72, p. 38-43, 2012.

4. REYES, A.; LANGSETH, M. Modeling of textured aluminum alloys used in a bumper system : Material tests and characterization. Computational Materials Science, v. 37, p. 246-268, 2006.

5. MALO, K. A.; HOPPERSTAD, O. S.; LADEMO, O. G. Calibration of anisotropic yield criteria using uniaxial tension tests and bending tests. Journal of Materials Processing Technology, v. 81, p. 538-544, 1998.

6. BRYNJULFSEN, M. Fatigue of Extruded AA6082 and AA7108 Alloys Marte Brynjulfsen. [s.I.] Norwegian University of Science and Technology, 2015.

7. PAULISCH, M. C. et al. The different dependencies of the mechanical properties and microstructures on hot extrusion and artificial aging processing in case of the alloys Al 7108 and Al 7175. Journal of Materials Processing Technology, v. 233, p. 6878, 2016.

8. FJELDLY, A.; SØRENG, A.; JØRGEN, H. Strain localisation in solution heat treated $\mathrm{Al}-\mathrm{Zn}-\mathrm{Mg}$ alloys. Materials Science and Engineering A, v. 300, p. 165-170, 2001.

9. DESCHAMPS, A. et al. Quantitative characterization of the microstructure of an electron-beam welded medium strength $\mathrm{Al}-\mathrm{Zn}-\mathrm{Mg}$ alloy. Materials Science and Engineering A, v. 517, p. 361-368, 2009.

10. MOUSAVI, M. G. et al. Effect of scandium and titanium - boron on grain refinement and hot cracking of aluminium alloy $7108 \mathrm{E} \mathrm{ff} \mathrm{ect} \mathrm{of} \mathrm{scandium} \mathrm{and} \mathrm{titanium} \mathrm{-} \mathrm{boron} \mathrm{on}$ grain refinement and hot cracking of aluminium alloy 7108 . Science and Technology of Welding and Joining, v. 4, n. 6, p. 381-388, 1999. 
11. GIANISELLE, F.; PADILHA, A. F.; FERNANDES, R. DO C. Evolução Microestrutural Durante a Homogeneização da Liga de Alumínio AA 7108. In: ABM Week 2017, São Paulo. Anais [...] 2017. p. 217-226

12. PADILHA, A. F.; PLAUT, R. L. Work Hardening, Recovery, Recrystallization and Grain Growth. In: TOTTEN, G. E.; MACKENZIE, D. S. (Eds.). . Handbook of Aluminum. New York: Marcel Dekker, 2003. p. 193-220.

13. MEYERS, M. A.; CHAWLA, K. K. Princípios de Metalurgia Mecânica. São Paulo: Edgar Blücher, 1982.

14. POLMEAR, I. J. Aluminium Alloys - A Century of Age Hardening. Materials Forum, v. 28, p. 1-14, 2004.

15. MARTIN, J. W. Precipitation Hardening. 1st Editio ed. Oxford: Pergamon Press, 1968.

16. STARKE, J. E. A.; HORNBO. Precipitation Hardening: From Alfred Wilm to the present. In: HIRSH, K.; SKROTZKI, B.; GOTTSTEIN, G. (Eds.). . Aluminum Alloys. Their Physical and Mechanical Properties. Weinheim: Wiley - VCH, 2008.

17. ARDELL, A. J. Precipitation Hardening. Metallurgical and Materials Transactions A, v. 16 A, p. 2131-2165, 1985.

18. HUME-ROTHERY, W.; RAYNOR, G. V. The Structure of Metals and Alloys. $4^{\circ}$ Edição ed. Londres: Institute of Metals, 1962.

19. HATCH, J. . Aluminum - Properties and physical metallurgy. [s.I.] Aluminum Association Inc. and ASM International, 1984.

20. PADILHA, A. F. Materiais de Engenharia. Curitiba: Hemus, 1997.

21. MURRAY, J.; PERUZZI, A.; ABRIATA, J. . Alloy Phase Diagrams. In: ASM Handbook. [s.l: s.n.].

22. POLMEAR, I. J. Light Alloys: Metallurgy of the Light Metals. $3^{\circ}$ Edition ed. Londres: Edward Arnold, 1995. 
23. DIETER, G. E. Mechanical Metallurgy. $3^{\circ}$ Edition ed. New York: McGraw-Hill Book Company, 1986.

24. MUSZKA, K.; MAJTA, J. EFFECT OF GRAIN REFINEMENT ON MECHANICAL PROPERTIES. Metallurgy and Foundry Engineering, v. 32, n. 2, 2006.

25. HANSEN, N. Hall - Petch relation and boundary strengthening. Scripta Materialia, v. 51, p. $801-806,2004$.

26. HALL, E. O. et al. The Deformation and Ageing of Mild Steel: III Discussion of Results. Proceedings of the Physical Society, v. 64, p. 747-753, 1951.

27. HUANG, T. et al. Strengthening mechanisms and Hall-Petch stress of ultra fine grained. Acta Materialia, v. 156, p. 369-378, 2018.

28. TAYLOR, G. I. The Mechanism of Plastic Deformation of Crystals - Part I. Proceedings of the Royal Society A, v. 538, p. 362-387, 1934.

29. ZHAO, Z. et al. Microstructure and properties of a $\mathrm{Cu}-\mathrm{Ni}-\mathrm{Si}-\mathrm{Co}-\mathrm{Cr}$ alloy with high strength and high conductivity. Materials Science and Engineering A, v. 759, n. 24, p. 396-403, 2019.

30. CARVALHO, L. G. DE et al. Study of Age Hardening Behavior in a 350 Grade Maraging Steel. Characterization of Minerals, Metals, and Materials, n. January, p. 2-10, 2015.

31. NEITE, G.; MFINSTER, D. U. Precipitation Hardening of Superalloys by Ordered Particles. Progress in Materials Science, v. 29, p. 177-319, 1985.

32. KELLY, A.; NICHOLSON, R. B. Precipitation Hardening. Progress in Materials Science, v. 10, n. 3, p. 151-383, 1969.

33. DAVIS, J. R. (ED.). ASM Specialty Handbook - Aluminum and Aluminum Alloys. EUA: ASM International, 1993.

34. Site da Universidade de Cambridge https://www.doitpoms.ac.uk/tlplib/solidification_a. Acesso em março/2018 
35. MEYERS, M. A.; CHAWLA, K. K. Mechanical Behavior of Materials. $1^{\circ}$ edição ed. New York: Cambridge University Press, 2009.

36. HILL, R. . Physical Metallurgy Principles. $1^{\circ}$ edição ed. Nova York: Van Nostrand, 1973.

37. FAN, Y. Precipitation Strengthening of Aluminium by Transition Metal Aluminides. 2012. Tese de Doutorado. Worcester Polytechnic Institute, 2012.

38. RANGANATHA, $R$. et al. Multi-stage heat treatment of aluminum alloy AA7049 Multi-stage heat treatment of aluminum alloy AA7049. Transactions of Nonferrous Metals Society of China, v. 23, n. 6, p. 1570-1575, 2017.

39. OZER, G.; KARAASLAN, A. Properties of AA7075 aluminum alloy in aging and retrogression and reaging process.pdf. v. 27, n. 11, p. 2357-2362, 2017.

40. ALUMINUM, N. Alloy Data Sheet 7108. Utrecht, 2010.

41. SCALCO, N. N. Efeito das Condições de Tratamento Térmico na Cinética de Envelhecimento Artificial da Liga 7108 Extrudada. 2017. Trabalho de Conclusão de Curso.Universidade Presbiteriana Mackenzie,São Paulo, 2017.

42. RAGHAVAN, A. Microanalytical study of the heterogeneous phases in commercial Al-Zn-Mg-Cu alloys. Metallurgical Transactions A, v. 16, n. 11, p. 1925-1936, 1985.

43. LAMB, J. Decomposition and its effects on mechanical properties in Al-ZnMg-Cu alloys.2016. Tese de Doutorado. Georgia Institute of Technology, 2016.

44. LENDVAI, J. Precipitation and Strengthening in Aluminium Alloys. Materials Science Forum, v. 217-222, p. 43-56, 1996.

45. WESTERMANN, I. et al. Ageing and work-hardening behaviour of a commercial AA7108 aluminium alloy. Materials Science and Engineering A, v. 524, p. 151-157, 2009.

46. WERENSKIOLD, J. C.; DESCHAMPS, A.; BRE, Y. Characterization and modeling of precipitation kinetics in an $\mathrm{Al}-\mathrm{Zn}-\mathrm{Mg}$ alloy. Materials Science and Engineering A, v. 293, p. 267-274, 2000. 
47. VILLARS, P.; PRINCE, A.; OKAMOTO, H. Handbook of Ternary Alloy Phase Diagrams. Volume 4. ASM International, 1994.

48. OLIVEIRA, J. C. P. T. Evolução da microestrutura e da textura durante a laminação a frio e a recristalização de alumínio com diferentes níveis de pureza. 2009. Tese de Doutorado. Escola Politécnica da Universidade de São Paulo, São Paulo, 2009.

49. MARTINS, J. D. E. P. Evolução da Microestrutura e da Textura Durante o Processamento de Chapas da Liga Al - Mn - Fe - Si (3003) Produzidas Por Lingotamento Contínuo: Um Estudo Comparativo com o Processo SemiContínuo. 2005. Tese de Doutorado. Escola Politénica da Universidade de São Paulo, São Paulo, 2005.

50. SOUZA, F. M. Estudo da microestrutura, da textura cristalográfica e da recristalização em chapas obtidas por lingotamento contínuo e semi-contínuo da liga de alumínio AA4006. 2012. Tese de Doutorado. Escola Politécnica da Universidade de São Paulo, São Paulo, 2012.

51. SALAZAR-GUAPURICHE, M. A. et al. Correlation of Strength with Hardness and Electrical Conductivity for Aluminium Alloy 7010. Materials Science Forum, v. 521, p. 853-858, 2006.

52. WILKES, P. On the anomalous electrical resistance of G.P. zones. Acta Metallurgica, v. 16, p. 863-866, 1968.

53. SUBERO, D.; LUIGGI, N. Electrical resistivity anomaly: A consequence of nanometric particles in a metal matrix. Journal of Computational Methods in Sciences and Engineering, v. 14, p. 29-43, 2014.

54. PANSERI, C.; GATTO, F.; FEDERIGHI, T. The quenching of vacancies in aluminum. Acta Metallurgica, v. 5, p. 50-52, 1957.

55. PANSERI, C.; FEDERIGHI, T. A resistometric study of preprecipitation in an aluminium $-1.4 \% \mathrm{Mg}_{2} \mathrm{Si}$ alloy. Journal of the Institute of Metals, v. 94, p. 99-107, 1966.

56. RAEISINIA, B.; POOLE, W. J. Electrical resistivity measurements: a sensitive tool for studying aluminum alloys. Materials Science Forum, v. 519-521, p. 1391-1396, 2006. 
57. ESMAEILI, S. et al. A study on the early-stage decomposition in the Al-Mg-Si-Cu alloy AA6111 by electrical resistivity and three-dimensional atom probe. Philosophical Magazine, v. 87, p. 3797-3816, 2007.

58. LUIGGI, N.; SIMON, P.; GUYOT, P. Residual resistivity during clustering in Al-Zn solid solutions. Acta Metallurqica, v. 28, p. 1115-1122, 1980.

59. WATERLOO, G. et al. Effect of predeformation and preaging at room temperature in $\mathrm{Al}-\mathrm{Zn}-\mathrm{Mg}-(\mathrm{Cu}, \mathrm{Zr})$ alloys. Materials Science and Engineering A, v. 303, p. 226-233, 2001.

60. LIU, D. et al. Quantitative study of nanoscale precipitates in Al-Zn-Mg-Cu alloys with different chemical compositions. Materials Science and Engineering A, v. 639, p. 245-251, 2015.

61. MARTIN, J. W.; DOHERTY, R. D. Stability of microstructure in metallic systems. Cambridge: Cambridge University Press, 1976.

62. MATSUBARA, E.; COHEN, J. B. The G.P. zones in Al-Cu alloys-II. Acta Metallurgica, v. 33, n. 1, p. 1957-1969, 1985.

63. FILHO, E. B.; BENTO, I.; SILVA, D. A. Conformação plástica dos metais. São Paulo: EPUSP, 2011.

64. Website da Companhia Brasileira de Alumínio. Disponível em: $<$ http://www.aluminiocba.com.br/produtos/produtos-transformados>. Acesso em abril/2018

65. CETLIN, P. R.; HELMAN, H. Fundamentos da Conformação. $2^{\circ}$ Edição ed. São Paulo: Editora Artliber, 2012.

66. AGUIAR, D. J. M. DE et al. Efeitos da laminação a frio na microestrutura de dois aços inoxidáveis duplex. In: A engenharia mecânica na UFTPR. Ponta Grossa: Casaletras, 2020. p. 37-47.

67. AGUIAR, D. J. M. DE. Estudo da Formação e Reversão de Martensita Induzida por Deformação na Austenita de Dois Aços Inoxidáveis Dupléx. 2012. Tese de Doutorado. Escola Politécnica da Universidade de São Paulo, São Paulo, 2012. 
68. KAPOOR, R.; NASSER, S. N. Determination of temperature rise during high strain rate deformation. Mechanics of Materials, v. 27, p. 1-12, 1998.

69. SOUSA, T. G. DE et al. Dislocation Density and Texture in Copper Deformed by Cold Rolling and Ecap. Materials Research, v. 21, n. 1, p. 1-6, 2018.

70. TAMAYO-MEZA, P.; YERMISHKI, V.; SANDOVAL-PINEDA, J. Thermally activated movement of screw dislocations in polygonized aluminum. A Revista Facultad de Ingeniería Antioquia, n. 67, p. 161-171, 2013.

71. PADILHA, A. F.; SICILIANO, F. J. Encruamento, Recristalização, Crescimento de Grão e Textura. $3^{\circ}$ Edição ed. São Paulo: ABM Associação Brasileira de Metalurgia, Materiais e Mineração, 2005.

72. HULL, D.; BACON, D. J. Introduction to Dislocations. $5^{\circ}$ Edição ed. Oxford: Elsevier Ltd, 2011.

73. HUMPHREYS, F. J.; HATHERLY, M. Recrystallization and Related Annealing Phenomena. $2^{\circ}$ Edição ed. Oxford: Elsevier Ltd, 2004.

74. KULHMANN, D. Zur Theorie der Nachwirkungserscheinnungen. Zeitschrift für Physik, v. 124, n. 7-12, p. $469-481,1948$.

75. RIOS, P. R. et al. Nucleation and Growth During Recrystallization. Materials Research, v. 8, n. 3, p. 225-238, 2005.

76. DOHERTY, R. D. et al. Current issues in recrystallization : a review. Materials Science and Engineering A, v. 238, p. 219-274, 1997.

77. CAHN, R. W. A new theory of recrystallization nuclei. Proceedings of the Physical Society of London, v. 63, n. 4A, p. 323-336, 1950.

78. BECK, P. A. The formation of recrystallization nuclei. Journal of Applied Physics, v. 20, 1949.

79. SANDSTROM, R.; LEHTINEN, E.; HEDMAN, I. Subgrain Growth in Al and Al - 1\% Mn during annealing. Journal of Materials Science, v. 13, n. 6, p. 1229-1242, 1978. 
80. LI, J. Possibility of subgrain rotation during recrystallization. Journal of Applied Physics, v. 33, n. 10, p. 2958-2965, 1962.

81. ROLLETT, A. D. et al. Grain boundary mobility - a brief review. Zeitschrift für Metallkunde, v. 95, n. 4, p. 226-229, 2004.

82. BURKE, J.; TURNBULL, D. Recrystallization and grain growth. Progress in Metal Physics, v. 3, p. 220-292, 1952.

83. VANDERMEER, R. A.; GORDON, P. The influence of recovery on recrystallization in aluminum. In: HIMMEL, L. (Ed.). . Recovery and Recrystallization of Metals. [s.I.] Interscience Publishers, 1962.

84. TAJALLY, M.; HUDA, Z. Recrystallization kinetics for aluminum alloy 7075 . Metal Science and Heat Treatment, v. 53, n. 5-6, p. 213-217, 2011.

85. KAISER, M. S. Fractional Recrystallization Behaviour of Al-Mg Alloy with Different Sc Addition Content. International Journal of Materials Science and Engineering, v. 2, n. 2, p. 136-140, 2014.

86. SARKAR, S.; WELLS, M. A.; POOLE, W. J. Softening behaviour of cold rolled continuous cast and ingot cast aluminum alloy AA5754. Materials Science and Engineering A, v. 421, p. 276-285, 2006.

87. VASUDEVAN, A. K.; DOHERTY, R. D. Aluminum Alloys-Contemporary Research and Applications: Contemporary Research and Applications. $1^{\circ}$ Edição. Elsevier Ltd, 1989.

88. PORTER, J. R.; HUMPHREYS, F. J. Nucleation of recrystallization at secondphase particles in deformed copper alloys. Metal Science, v. 13, n. 2, p. 1315-1322, 1983.

89. TANGEN, S. et al. Effect of concurrent precipitation on the texture evolution during continuous heating of multi directionally forged solution treated Al-Cu-Mg alloy. Metallurgical and Materials Transactions A, v. 41A, p. 2970-2983, 2010.

90. S., D.; GUYOT, P.; PELISSIER, J. Study of recrystallization in aluminium alloys containing second phase particles. Acta Metallurgica, v. 31, n. 9, p. 1315-1322, 1983. 
91. HORNBOGEN, E. Electron Microscopical Investigation of Recrystallization of alloys in which precipitation can occur. Praktische Metallographie, v. 7, p. 349-360, 1970.

92. HUMPHREYS, F. J.; JONES, M. J. Interaction of recrystallization and precipitation: the effect of $\mathrm{Al} 3 \% \mathrm{Sc}$ on the recrystallization behaviour of deformed aluminium. Acta Materialia, v. 51, n. 8, p. 2149-2159, 2003.

93. LEE, E. U.; KRANZLEIN, H. H.; UNDERWOOD, E. E. Dynamic recovery in aluminum. Materials Science and Engineering, v. 7, n. 6, 1971.

94. KAIBYSHEV, R.; MALOPHEYEV, S. Mechanisms of Dynamic Recrystallization in Aluminum Alloys. Materials Science Forum, v. 794-796, p. 784-789, 2014.

95. MC QUEEN, H. J.; JONAS, J. J. Recovery and Recrystallization During High Temperature Deformation. Nova York: Academic Press, 1975.

96. TURNBULL, D.; BURKE, F. Recrystallization and grain growth. Progress in Metal Physics, v. 3, p. 220-292, 1952.

97. HUDA, Z.; ZAHARINIE, T. Kinetics of grain growth in 2024-T3: An aerospace aluminum alloy Kinetics of grain growth in 2024-T3: An aerospace aluminum alloy. Journal of Alloys and Compounds, v. 718, n. June, p. 128-132, 2009.

98. BECK, P. A. Effect of recrystallised grain size on grain growth. Jounal of Applyed Physics, v. 19, p. 507-509, 1948.

99. BIROL, Y. Impact of partial recrystallization on the performance of $6005 \mathrm{~A}$ tube extrusions. Engineering Failure Analysis, v. 17, n. 5, p. 1110-1116, 2010.

100. VAN GEERTRUYDEN, W. H. et al. Evolution of Surface Recrystallization during Indirect Extrusion of 6xxx Aluminum Alloys. Metallurgical and Materials Transactions A, v. 36, n. April, p. 1049-1056, 2005.

101. EIVANI, A. R.; ZHOU, J.; DUSZCZYK, J. Mechanism of the formation of peripheral coarse grain structure in hot extrusion of Al-4 . $5 \mathrm{Zn}-1 \mathrm{Mg}$. Philosophical Magazine, v. 6435, p. 1-9, 2016. 
102. IHARA, K.; SHIKAMAT; MORITA, K. The Effect of the Extrusion Temperature on the Recrystallization Textures of an Extruded AA6005C Alloy. KOBELCO TECHNOLOGY REVIEW, v. 31, p. 60-75, 2013.

103. KAZANOWSKI, P. et al. Mechanical and microstructural performance of convex dies in axisymmetric extrusion - Theory and experimental verification. Materials Science and Engineering A, v. 404, n. 1-2, p. 235-243, 2005.

104. EIVANI, A. R.; ZHOU, J. Application of physical and numerical simulations for interpretation of peripheral coarse grain structure during hot extrusion of AA7020 aluminum alloy. Journal of Alloys and Compounds, v. 725, p. 41-53, 2017.

105. BIROL, Y. Effect of extrusion press exit temperature and chromium on grain structure of EN AW 6082 alloy forgings. Materials Science and Technology, v. 31, n. 2, p. 207-212, 2015.

106. SWEET, E. D. et al. Effects of extrusion parameters on Coarse Grain Surface Layer. Proceedings of the 8th Internacional Aluminum Extrusion Technology Seminar, v. 1, p. 115-126, 2004.

107. SWEET, E. D.; CHARLES, E. S.; COUPER, M. J. The Effect of Fe and Mn Content on Coarse Grain Formation During Homogenisation of 6000 Series AlloysProceedings of the 9th International Conference on Aluminium Alloys. Anais...2004

108. HIRSCH, J. R.; ALUMINIUM, H. Texture evolution during rolling of aluminium alloys. Light Metals, n. December 2015, p. 1071-1077, 2008.

109. VIANA, C. . DA; PAULA, A. DOS S. Texturas de deformação. In: TSCHIPTSCHIN, A. P. et al. (Eds.). Texturas e Relações de Orientação. São Paulo. p. 35-54.

110. RANDLE, V.; ENGLER, O. Introduction to Texture Analysis Macrotexture, Microtexture \& Orientation Mapping. 1st ed. ed. London: CRC Press, 2000.

111. STÜWE, H. P.; FAUSTMANN, J. Introducción a las texturas de los materiales metálicos. Madrid: Editorial Montecorvo, 1969. 
112. BUNGE, H. J. Texture Analysis in Materials Science - Mathematical Methods. Londres: Butterworths, 1982.

113. ANTENOR, J. P. M. Estudo da Evolução da Textura do Alumínio Puro Processado por Extrusão Angular em Canal (EAC).2011. Trabalho de Conclusão de Curso. Universidade Federal do Rio Janeiro, Rio de Janeiro, 2011.

114. HIRSCH, J.; LÜCKE. Mechanism of deformation and development of rolling textures in polycrystalline f.c.c. metals - I Description of rolling texture development in Cu-Zn alloys. Acta Metallurgica, v. 36, p. 2863-2882, 1988.

115. LIMA, N. B. DE; LIMA, L. M. G.; PADILHA, A. F. Texturas de Recristalização. In: Texturas e Relações de Orientação. $2^{\circ}$ Ediçao. São Paulo. p. 107-128.

116. $\mathrm{KONDOH}, \mathrm{K}$. et al. Anisotropy Of Texture-Controlled Powder Metallurgy Magnesium Alloys Via Roll- Compaction Process. Journal of Multidisciplinary Engineering Science Studies, v. 2, n. 8, p. 810-814, 2016.

117. ZHANG, L. et al. Texture, Microstructure and Mechanical Properties of 6111 Aluminum Alloy Subject to Rolling Deformation. Materials Research, v. 20, n. 5, p. 1360-1368, 2017.

118. GALEGO, E. GALEGO, E. Desenvolvimento de programa computacional para dados de textura obtidos pela técnica de difração de raios X. 2004. Dissertação de Mestrado. Instituto de Pesquisas Energéticas e Nucleares, São Paulo, 2004.

119. EIVANI, A. R. et al. An experimental and theoretical investigation of the formation of $\mathrm{Zr}$-containing dispersoids in $\mathrm{Al}-4.5 \mathrm{Zn}-1 \mathrm{Mg}$ aluminum alloy. Materials Science and Engineering A, v. 527, p. 2418-2430, 2010.

120. AYER, R. et al. Microanalytical Study of the Heterogeneous Phases in Commercial Al-Zn-Mg-Cu Alloys. Metallurgical Transactions A, v. 16, n. November, p. 1925-1936, 1985.

121. CULLITY, B. D. Elements of X-Ray Diffraction. $2^{\circ}$ Edição ed. Massachusetts USA: Addison-Wesley Publishing Company, 1978.

122. INTERNATIONAL UNION OF CRYSTALLOGRAPHY. International Tables for X-Ray Crystallography. BirminghamnKynoch Press, 1974. 
123. GOW, K. V. Secondary recrystallization in aluminium extrusions. Acta Metallurgica, v. 2, n. 3, p. 394-405, 1954.

124. TARIQ, F.; NAZ, N.; AHMED, R. Characterization of Material Properties of 2xxx Series Al-Alloys by Non Characterization of Material Properties of 2xxx Series Al-Alloys by Non Destructive Testing Techniques. Journal of Nondestructive Evaluation, v. 31, n. 1, p. 17-33, 2014.

125. MATTHEW, S.; AGNEW, S. R. Predictive Sensitization Modeling for AA5XXX Aluminum Alloys including Non-Isothermal Cases. Corrosion, v. 72, n. 2, p. 169-176, 2016.

126. MAUDUIT, A.; GRANSAC, H. Study of the Precipitation Kinetics and Mechanisms in 6000 Series Aluminium Alloys Through the Measurement of Electrical Conductivity. Annales de Chimie - Science des Matériaux, v. 44, n. 3, p. 141-149, 2020.

127. ZEMENOVÁ, P. et al. Calculations of Avrami exponent and applicability of Johnson-Mehl-Avrami model on crystallization in Er:LiY(PO3)4 phosphate glass. Journal of Thermal Analysis and Calorimetry, v. 141, p. 1091-1099, 2020.

128. AUSTIN, J. B.; RICKETT, R. L. Kinetics of the Decomposition of Austenite at Constant Temperature. Transactions of the American Institute of Mining and Metallurgical Engineers, n. 135, p. 396-415, 1939.

129. PADILHA, A. F. Utilização da Técnica de Difração de Elétrons Retroespalhados na Caracterização Microestrutural dos Materiais. In: Congresso da Sociedade Brasileira de Microscopia e Microanálise. Anais [...].1999 